ILLUSTRA'TED CA'TALOGUE

OF THE

\title{
IMPOR'TAN'T COLIEC'TION
}

OF

\section{PAINTINGS, WATER COLORS \\ PASTELS, DRAWINGS AND PRINTS}

COLLECTED BY THE JAPANESE CONNOISSEUR THE LATE

\section{TADAMASA HAYASHI OF TOKYO, JAPAN}

Chief Commissioner for the Japanese Government to the Exhibition Universelle, Paris, 1900

TO BE SOLD A'T UNRESTRIC'TED PUBLIC SALE BY ORDER OF MADAME HAYASHI ON THE DATES HEREIN STA'TED

The Sale will be conducted by Mr. Thomas E. Kirby, of 'THE AMERICAN AR'T ASSOCIATION, Managers MADISON SQUARE SOUTH NEW YORK 1913 


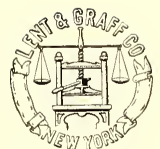


ON FreE VIEW

At THE AMERICAN ART Galleries

MADISON SQUARE SOUTH, NEW YORK

BEGINNING FRIDAY, JANUARY 3, 1913

AND CONTINUING UNTIL THE DATE OF SALE

\section{COLLEC'TION}

OF THE LATE

\section{'TADAMASA HAYASHI \\ OF TOKYO, JAPAN}

Unrestrictede Public Sale

BY ORDER OF MADAME HAYASHI

Wednesday EVEnING, JANUARY 8

A'T 'THE AMERICAN AR'T GALLERIES

AND

IN THE GRAND BALLROOM OF THE PLAZA FIFTH AVENUE, 58 тн TO 59 тн STREETS

\section{Thursday EVEnING, JANUARY 9}





\section{CONDITIONS OF SALE}

1. The highest bidder to be the Buycr, and if any dispute arises between two or more Bidders, the Lot so in dispute shall be immediately put up again and re-sold.

2. The Auctionecr reserves the right to reject any bid which is merely a nominal or fractional advance, and therefore, in his judgment, likcly to affect the Sale injuriously.

3. The Purchasers to give thcir names and addresses, and to pay down a cash deposit, or the whole of the Purchase-money, if required, in default of which the Lot or Lots so purchased to be immediately put up again and re-sold.

4. The Lots to be taken away at the Buyer's Expense and Risk: within twenty-four hours from the conclusion of the Sale, unless otherwise specified by the Auctioneer or Managers previous to or at the time of Sale, and the remainder of the Purchase-money to be absolutely paid, or othcrwise settled for to the satisfaction of the Auctioneer, on or before delivery; in default of which the undersigned will not hold themsclies responsibie if the lots be lost, stolen, damaged, or destroyed, but they will be left at the sole rish of the purchaser.

5. While the undersigned will not hold themsclves responsible for the correctness of the description, genuineness, or authenticity of, or any fault or defect in, any Lot, and make no IVarranty whatever, they will, upon receiving previous to date of Sale trustworthy expert opinion in writing that any Painting or other Work of Art is not what it is represented to be, use every effort on their part to furnish proof to the contrary; failing in which, the object or objects in question will be sold subject to the declaration of the aforesaid expert, he being liable to the Owner or Owners thereof for damage or injury occasioned thereby.

6. To prevent inaccuracy in delivery and inconvenience in the settlement of the Purchases, no Lot can, on any account, be remozed during the Salc.

$\%$ Upon failure to comply with the abore conditions, the money depositcd in part payment shall be forfeited; all Lots uncleared within one day from conclusion of Sale (unless otherwise spccified as above) shall be re-sold by public or private sale, without further notice, and the deficicncy (if any) attending such re-sale shall be made good by the defaulter at this Sale, together with all charges attending the same. This Condition is withont prejudice to the right of the Auctioneer to enforce the contract made at this Sale, without such re-sale, if he thinhs fit.

8. The Undersigned are in no manner connected with the business of the cartage or packing and shipping of purchases, and althongh they will afford to purchasers every facility for employing careful carricrs and packers, they will not hold themselves responsible for the acts and charges of the partics engaged for such services.

The AMERICAN ART ASSOCIATION, Managers. THOMAS E. KIRBY, Auctioneer. 



\section{NO'TE}

Occasional divergences will be noticed between the titles preceding the descriptions and the titles under the illustrations in this catalogue. The illustrations were all made and printed in Japan, for 'Tadamasa Hayashi, and in the transcriptions thereon of French titles, and sometimes of signatures, certain errors are obvious. A few it has been necessary to correct in the text; for the most part and so far as possible the titles have been preserved as they were recorded for 'Tadamasa Hayashi. 
. 


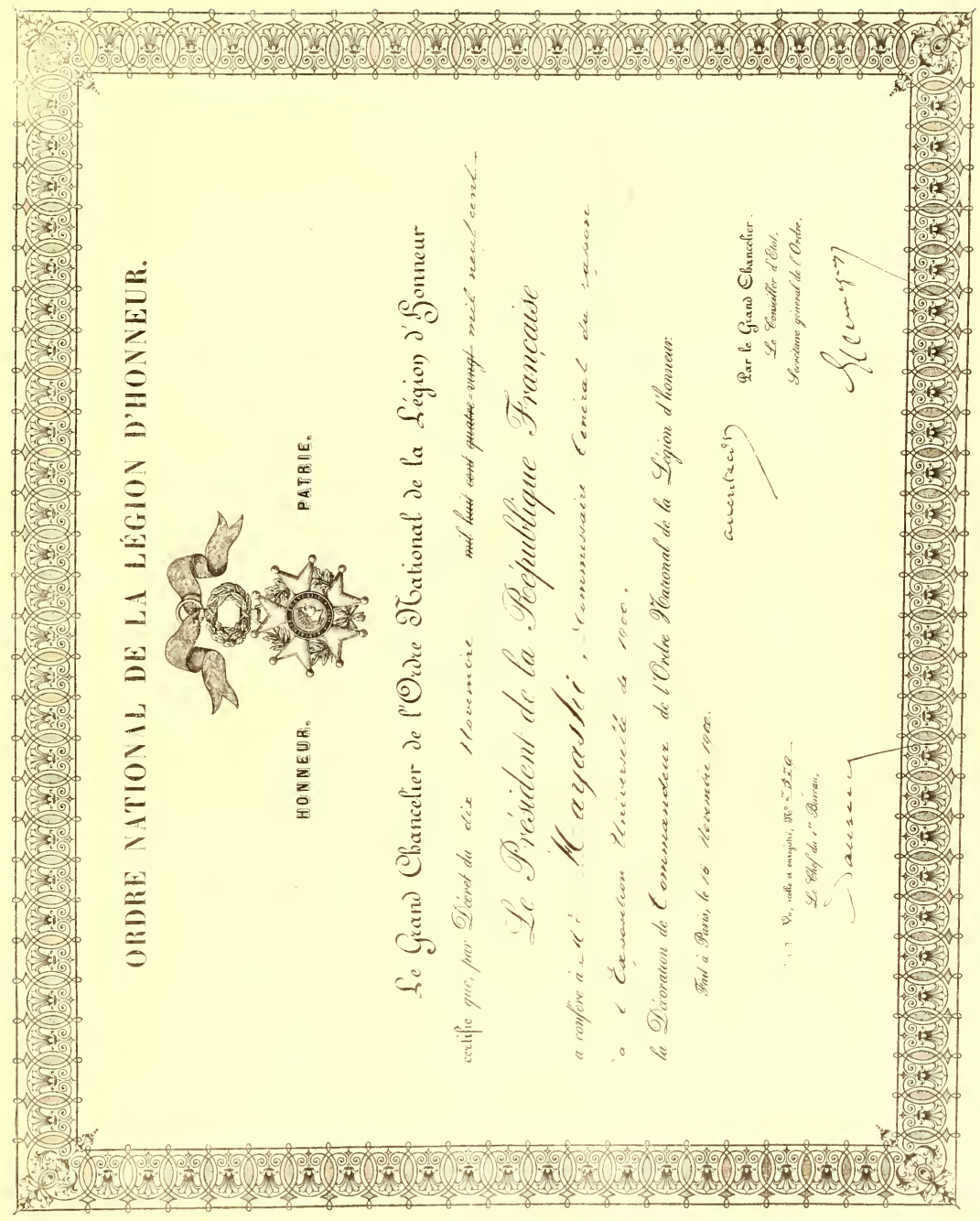





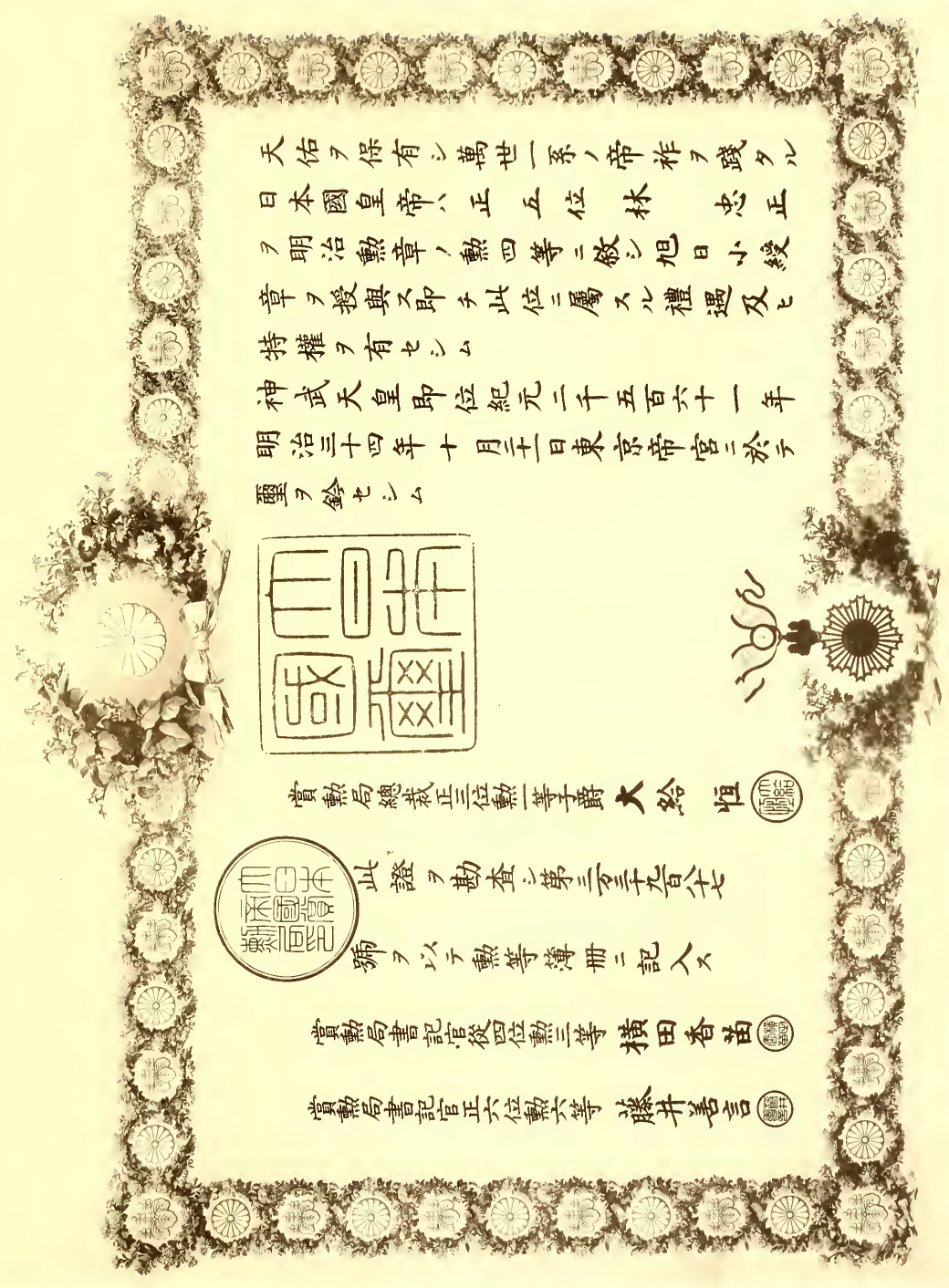


Mutsunito, Emperor of Japan, by Grace of Heaven, and seated on the throne occupied by the same dynasty from Time Immemorial, causes Tadamasa Hayashi, Fifth Senior Court Rank, to be ranked in the Officier (or class of the order of the Rising Sun), and confers upon him the insignia of that order, and accords him the privileges and courtesies due to the said rank.

In witness whereof, we have caused the Grand Seal of the Empire to be affixed at our Palace, at Tokyo, this twenty-first day of the tenth month of the thirty-fourth year of Meiji, corresponding the twenty-five hundred sixty-first year of the coronation of the Emperor Jimmu (A.D. 1901).

Grand Seal of Emperor signed:

Grand Cordon and the Third Senior Court Rank, Vice-Count Wataru Ogiu, President of the Imperial Bureau of Decoration.

Visé and countersigned as No. 33987 of the Imperial Order Register, Commandeur and the Fourth Junior Court Rank:

Kanaye Yokota, Secretary of the Imperial Bureau of Decoration. 
APPRECIATIONS 



\section{A FOREWORD}

I am fulfilling the wishes of the wife of my friend. Tadamasa Hayashi, in saying a few words about his collection of French paintings. Tadamasa Hayashi is known to all American and European friends of Asiatic art as one of its best connoisseurs and most fortunate collectors. The auction of his wonderful $\mathbf{J}$ apanese treasures in Paris will never be forgotten, but few know that he had also the greatest interest in the art of the West.

While most of the $\mathbf{J}$ apanese remain indifferent and even hostile to our art, and particularly to our paintings, Tadamasa Hayashi followed its development with the most intelligent interest. In Paris, where he lived during the greater part of his adult life, he had the friendliest relations with the most important artists, and his collection of pictures arose out of this living intercourse, which lasted more than twenty years.

Many who look for the first time upon the collection will be astonished to see with what remarkable acumen this Japanese recognized what was really important in the confusing whirlpool of art production. His collection would, in fact, do honor to the best European connoisseurs. It does not contain, as do many other's, only great names, but, what is of far more importance, great works. All of the most celebrated names are borne here by works which are really worthy of their reputation.

For that matter, the paintings will speak best for themselves - the luminous Monets and Renoirs, the characteristic Degases, the pleasing Collins, among them the great "Dance on the Seashore," which was so much admired at the Exposition of 1900; the noble Sisleys, Raf- 
faëllis and Vidals, the powerful Guillaumins, the Pissaros, and, not least, the dreany landscapes of the early-deceased Blache.

Hayashi had made his collection with no idea of a later sale, but chiefly out of a pure delight in the subject matter. Besides, he cherished the hope of later making his collection useful to his countrymen. He expected much for the future of Japanese art, which was close to his heart, from their study of European art, and he knew that the pictures which had hitherto reached Japan from the West were by no means sufficient for that purpose.

It was not granted to the tireless man to carry out this plan. Soon after his return home, he succumbed to the illness which ended his rich life within a year. His precious collection of European paintings was left behind him, unconsidered and unused. The hope that they would be bought by the Imperial Museum, and thus his original intention of initiating the Japanese public into the spirit of European art be fulfilled, was disappointed through lack of means, and Japanese private houses, with their narrow, low rooms, offer no place for such pictures.

Since even in the home of the family he left behind no satisfactory exhibition was possible, and since, besides, the moist Japanese climate threatened the life of the canvases, his heirs have finally decided to give back to the West these treasures of Western art. May they there find the honor which they deserve!

\section{Ernst Grosse.}

\section{Toкуо.}




\section{TADAMASA HAYASHI}

The late Tadamasa Hayashi was born on December 12, 1853, at 'Takaoka City, in the province of Etchü, and was the second son of Dr. Gentei Nagasaki, a physician of that city.

His early education, which was largely in French literature, was received from Tachu Hayashi, who belonged to the gentry of the 'Toyama clan, by whom he was afterward adopted. Later on he entered the Daigaku Nanko, the only college then in existence in Japan, and studied French political science, with the purpose of engaging in public affairs.

While he was in college, the most extraordinary transformation in politics, as well as in the social state, took place, abolishing the feudal system and the Shogunate, and restoring power to the Imperial throne.

Being satisfied with the new order, Hayashi changed his original plan, and, despite the kindly protest of President Hamao, he left college a few months before graduation, with the intention of going to France to study engineering there.

During his student days in France he experienced many hardships and trying circunstances, yet he did not give up his study.

In 1883, success finally came to him through his establishment of an art firm in Paris, which rapidly expanded and made him known the world over in the realm of art.

He was on intimate terms with the late Prince Ito and Viscount Sone, and when, in 1900, the World's Fair enterprise was in progress, the $\mathbf{J}$ apanese Government consulted him in the matter, and, availing themselves of his 
advice and experience, finally appointed him chief comnissioner of the Japanese exhibit, with the fifth title of official rank of the "Sho-Goi." His services were entirely satisfactory, and after the close of the fair the Japanese Government decorated him anew, while the French Government made him a Commander of the Legion of Honor.

Far-seeing, with natural-born talent, devoting with heart and spirit all of his time to the cultivation of art, he deeply deplored the fact that the Oriental people were not afforded opportunities to learn and study Occidental art.

For this reason, he made a collection of paintings by Western masters, the idea being thereby to benefit artists and educate the public. As to the collection itself, for which he spent a sum of no small consideration, he intended to present it as a gift to the Imperial household.

He died on April 4, 1906, still in the prime of life.

What he contributed to the world of art, at home and abroad, cannot be easily measured, and we all owe to him a deep and sincere gratitude. Had he lived a few years longer, we have no doubt that he could have accomplished still greater successes.

The pictures reproduced herein number upward of 160. We firmly believe that the album will prove a most beneficial companion to lovers of art.

Y. Hoshino.

Tокуо. 


\section{HAYASHI'S COLLECTION OF FRENCH PICTURES}

Although Western scientific culture passionately interests the Japanese, it is but rarely that our art attracts their curiosity, and, with the exception of the painters who come to learn from us processes which they think more in accordance with their new ideals, they remain indifferent to the works of our artists. Their national traditions still hold them captive and their eyes have not learnt our point of view.

T. Hayashi was, to my knowledge, the only Japanese who really loved and understood the arts of Europe. Coming to Paris when very young, in the employ of a society which intended to show ancient Japanese art works at the Universal Exhibition of 1878, he did not have long to wait before artists came to his stall in the Champ de Mars. Truly, it was the first time that Europe was enabled to see the real treasures of old Japan, and perhaps the great public hardly became aware of the occurrence, but those who already were working for the renovation of our vision were singularly impressed. Advanced critics and those painters called "Impressionists" stopped for a long time before these semi-disclosed wonders, and as their custodian was very intelligent, and as he was in a position to give them all the information they could desire, they could not fail to enter into friendly intercourse with him, and soon he became their friend. There must have been with the best amongst them, and especially with the critics, with the Goncourts, Burty, Gonse, many long conversations in which, whilst the Japanese initiated them into the mysteries 
of his national art, he learned in return from them to know our art and to appreciate it.

When the exhibition closed these friendly relations did not cease, warm friendships were made, and when Iayashi set up on his own account in a little flat in the Rue d'Iauteville, art lovers, critics and artists continued to visit him. 'Those upon whom this first revelation of Japanese art had made the deepest impression were the painters of that new school, who, with Claude Monet. sought especially to transfer to canvas the charm of the play of light, and its reflections; or those draughtsmen gifted with a marvellously keen eye, such as Bracquemond or Degas, who found in the paintings and prints of Japan something of their own ideals; and still to-day these proclaim openly all they owe to that art, which filled them with enthusiasm. The same reasons which brought them to Japan drew the young Japanese to them. His eye, accustomed to the luminous transparencies dear to the landscape painters of his country, found pleasure in the subtle mannerisms of Monet's canvases, and all that intensity and fulness of life compressed into a pastel of Degas reminded him of the masterly draughtsmen of his own land. They chatted long and often, and, indeed, much as it would have been a joy for our painters to possess some of the masterpieces which they admired in the hands of the dealer, Hayashi himself yearned to decorate his rooms with some paintings of those artists whom he admired. But the great public had not yet found either the Impressionists or the Japanese, and the hard life which this little group led precluded all thought of purchase.

But if money was lacking, another way remained open to gratify their tastes. As in the fable the blind and the halt had formerly associated their miseries, our friends also entered into the way of exchanges. Claude Monet 


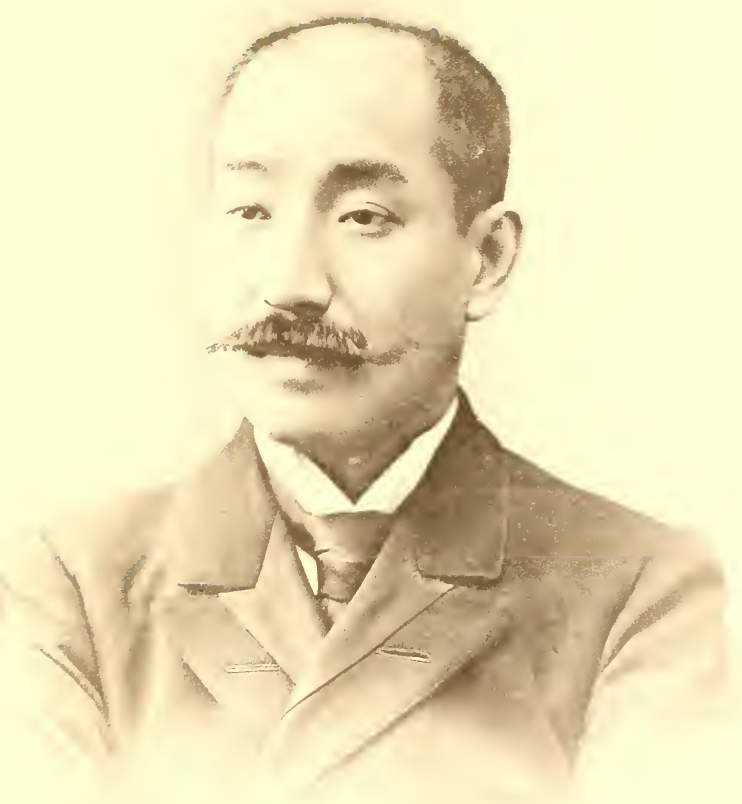



has shown us admirable prints and exquisite pottery, which he obtained from Hayashi in exchange for pictures then unsaleable, and Degas possesses certain albums from the same source, especially those Moronobu which still to-day he almost worships, and for which he gave a few precious drawings. When Hayashi's business had extended he could assuredly acquire in another manner those productions which charmed him, and his collection includes the works of artists into whose studios a $J$ apanese work never entered. Still, he always loved the other method. It was by exchange that Raphaël Collin obtained the most beautiful sword-guards and the best prints of his collection; and when, after twenty-five years' sojourn in Europe, Hayashi decided to return to his native land, it was in exchange for an incomparable series of inros that he procured from Henri Rivière the decorations for the villa which he wanted to build for himself in Tokyo-that villa which was never completed except in his dreams.

Hayashi had not only understood modem French art-that of the little group of $\mathbf{J}$ apan-lovers amongst the artists, in the midst of whom he lived in Paris, and after all the best in contemporary France-but he had also penetrated into the foreign schools and those of the past. During the frequent visits he paid in Germany to Prof. Grosse (his most intimate friend in Europe, and who had, owing to a passionate taste for them, some of the most beautiful objects of Far Eastern art which came to Europe), he learned to appreciate Boecklin, and $\mathbf{M}$. Grosse has told me of the long talks in which these two, the German and the Japanese, penetrated together into the art of that painter, so mysterious for most Frenchmen, even for those who wish to understand him. Indeed, once when I was going through the rooms of the Louvre with Hayashi, he stopped before a red chalk drawing of Wat- 
teau's; for a while he remained entranced before it, then, turning to me with his smile, at the same time full of irony and of deep conviction, he said: "What can you want of Utamaro, when you possess a man such as this?" It was a whimsical sally, and yet not such a sally as one might think, for, true Japanese though he was, he only half enjoyed those prints which delight us. They were to him a source of profit as well as pleasure, and to them he owed a large part of his fortune, but he set things in their proper places, and he remained above all the fervent admirer of the great arts of his country-paintings, sculpture, lacquer work, pottery and sword cases. Perhaps what he loved most in his prints was that they had procured for him the beautiful collection of modern paintings which were his joy, for it was to the prints, particularly, that Monet and Degas were attached. As the dealers in old pictures disdained to exchange and wanted hard cash, Hayashi limited himself to the work of contemporary artists, and those who have seen his little gallery will agree that he was not wrong in doing so.

But they are the select few, and it was a special privilege to be admitted to his private apartment. Hayashi's show-rooms were, after 1890, in a fine first-floor flat in the Rue de la Victoire, where he had Japanese things only. But on the fourth floor, at the top of the house, some rooms had been furnished for his personal use, and there it was that he piled up his treasures of French painting. And perhaps "piled up" are the right words, because on the walls there was hardly anything. 'They were bare walls, and when he wished to show a painting to a friend for whom he had a particular regard, he had to draw it out from some hiding place, the mystery of which no one had ever fathomed. He acted with his pictures as Japanese art lovers with their paintings, not showing 
them all at a time, but contriving agreeable surprises each time they were brought out of their prisons. Moreover, we firmly believed that he always sent or took direct to Japan most of the French paintings he had acquired, thus saving them from an extended stay in Paris, and hastened to place them in the selected place which it was his intention they should never leave.

Hayashi had wished to spend his old age in Japan; he hoped to enjoy there a fortune acquired by his unremitting toil, in the midst of the Japanese masterpieces which he had reserved for himself and had always refused to sell, among the French paintings which he had collecter one by one, and with each of which was associated a recollection. A pretty house should receive them, and after his death the Museum of Tokyo was to inherit them, for Hayashi wished those things which had so brightened his life to give joy to many others after he had been gathered with his ancestors. And not only were they to give joy to all others, but, ardently patriotic as he was, he had in mind the education of his countrymen and their artistic development; he thought they could benefit by the study of those French painters who had so ingeniously renovated Western traditions by contact with Japanese art, and he was proud to think that 'Tokyo would have a museum of modern paintings such as few European capitals could boast of. Not that he had conceived any illusions upon the relative value of his pictures. He was well aware that he did not possess capital masterpieces such as financiers alone could pay for, and which satisfy their vanity rather than their love; but he was conscious that each of the pieces he had chosen struck an exquisite note, was a theme of individuality, a gem for a refined collector, and that they would minister to his memory as they had brightened his life. 
Alas, the dream was never realized. Death took IIayashi before he was able to put his affairs in order as he wished. His canvases were never hung as he wanted them in the house which his imagination had conjured. They will not find a peaceful and safe resting place in the Tokyo Museum, and they will not serve as models for Japanese painters. The fire of the auction-room will scatter them, not on their native land, but in distant countries beyond the ocean. Could he who so loved them in his lifetime but have foreseen their fate, he would perhaps have grieved at first, and then resigned himself. He would have felt that these pieces of the highest taste would only be bought by art lovers capable of understanding them, that they would join in their new dwelling places other paintings worthy of them, and he would have soothed himself with the certainty that they would bring afresh to others the joy that they had given him. Let us, the Parisian friends of Hayashi, hope so in our turn, in now bidding farewell, doubtless forever, to those works which we loved with him.

Raymond Koechuin. 


\section{TADAMASA HAYASHI SOME RECOLLECTIONS}

I became acquainted with Tadamasa Hayashi about 1884, when he was some thirty years of age. He came to me to introduce a young Japanese student, Seiki Kuroda, who, after some years successfully devoted to literary studies in our old Quartier, later became my pupil, and who has since made for himself in his own country a great name as one of the most famous painters of modern Japan. Hayashi's open and truly "Parisian" mind had been impressed by the trend of modern art, and finding interest in every artistic manifestation, he was one of the first to understand, at the very dawn of their career, those artists whose work was stamped with an audacity, an originality, which, although apparent, was yet beyond the ken of the vulgar crowd.

The paintings of Monet or Degas, the drawings of Renouard, the colored engravings of Théodore Rivière, had struck him with a deep sense of admiration, and with an enlightened connoisseurship he acquired a number of their works from these masters before their great successes. Personally, my studies of nude life in the open had found favor in his eyes, and he expressed the wish to possess several of my most important paintings.

Conversely, IIayashi initiated us in an exquisite manner into that world unknown and full of marvels, whose precious relies he accumulated in his flat of the Rue de la Victoire, where every new visit brought forth fresh pleasure and delight. I cannot do justice to the delicate and graceful manner with which he showed us those fine potteries from Korea and Japan, powerfully modeled in the 
finest taste and the most unexpected forms in a clay that almost lives; or those noble figures, sober of gesture, dignified in their august mien, which, whether of gilt bronze or lacquered wood, had been the erstwhile ornaments of Buddhist shrines; or yet the kakemono of pure and refined style, the prints in rare colors or delicate tones, the quaint metal work, and that precious marvel of perfection which we call lacquer. Works of a peculiarity which enhanced the perfection of the esthetic spirit that created them, their contemplation was at once a revelation and a feast for the mind and the eye, a rare pleasure, and a splendid lesson withal.

Again and again I visited Hayashi, and I so felt the charm of all these things of beauty that $I$ yearned to possess at least a few, which I treasure to this day.

Every month the "Diner Japonais," founded by Bing, brought together those worshippers of the art of Nippon who lived in Paris, and we met at the same table; Edmond de Goncourt, S. Bing, Alexis Rouart, the painter Whistler, Ary Renan, Gillot, Manzi, Ch. Mourier, the collector Groult, Raymond Koechlin, Migeon, Blondeau, and a few others, all passionately fond of that exquisite art. Hayashi, steeped in art to his very soul, supplied us information and explanations with indefatigable patience and charming good nature.

Those were pleasant nights, but of the gifted and refined men in whose midst they were spent, many, alas! have now departed this world.

In 1898 Hayashi left us to seek in Japan some further art treasures, and to prepare, on behalf of the Japanese Government, the Retrospective section of the Exhibition of 1900. 'This masterpiece was for him and for his country a real triumph, and for our eyes an unparalleled feast. In the midst of gardens surrounded by 
ponds stood a building, copy of a famous temple, hoarding the rarest types, of which only a few isolated specimens had been shown us before by Hayashi, and at last the public had an opportunity to understand all the grace and all the strength of the Japanese soul.

Alone a Japanese with so Parisian a mind, as was Hayashi, could have brought together in Paris, with so much tact and discrimination, so complete an ensemble. and no words can express the gratitude we owe to this man of taste for this initiation to such sublime beauty.

When, after this success, Hayashi decided to return home forever, and scattered his collections, when the time came for the banquet at which before his start we wanted to give him a lasting token of our affectionate gratitude, we felt almost abashed to bring a bronze to this refined connoisseur. Yet the work was signed Barye; but somehow the cast appeared poor beside those magnificent cire perdues which he had so often allowed us to admire. Over that banquet hovered an atmosphere of true cordiality, of warm sympathy, yet mingled with dismay at the departure of a very dear friend, and the emotion conspicuous in the toasts was true and sincere.

Alas, poor Hayashi! A letter received shortly afterward from Tokyo brought us the sad tidings of his precarious health, together with a portrait, in which one would hardly have known him. Yet he wrote without a plaint, with a smiling philosophy; true to his race, he would have grieved to cause us sorrow.

Short was his enjoyment of that fine collection of modern French works of art which he had carefully accumulated in his sojourn of over a score of years. He had found pleasure in showing to his countrymen, so fond of Western novelties, the productions of masters who during that period had been his friends and his preferred 
painters; he had hoped to influence the taste of 'Tokyo artists and dilettanti in a happy manner by the variety and the individuality of the latest creations of French paintings at the end of the Nineteenth Century, and to that end he had constructed in his house-decorated in European style by Parisian friends - a hall, the high windows of which opened over a flower garden.

But he departed this life before the realization of his hopes, and this beautiful collection will soon be scattered. May its contents be understood and treasured; may they find resting places in the hands of amateurs as fervently appreciative as he was himself.

For the widow and the young son of my lost friend, I have only to wish the successful issue, and that it may be seen how, amongst the numberless host of ordinary works, Hayashi has discriminated many full of life, full of true individuality, with as much tact in his appreciation of Western art as he had shown of taste and refinement in collecting and bringing together the masterpieces of his own country.

From the French of Raphä̈L Colidx. 


\title{
PRINTS AND LITHOGRAPHS
}

\author{
TO BE SOLD IN
}

\author{
THE AMERICAN ART GALLERIES \\ MADISON SQUARE SOUTH
}

On Wednesday Evening, January 8th, 1913

BEGINNING AT 8.15 O'CLOCK 



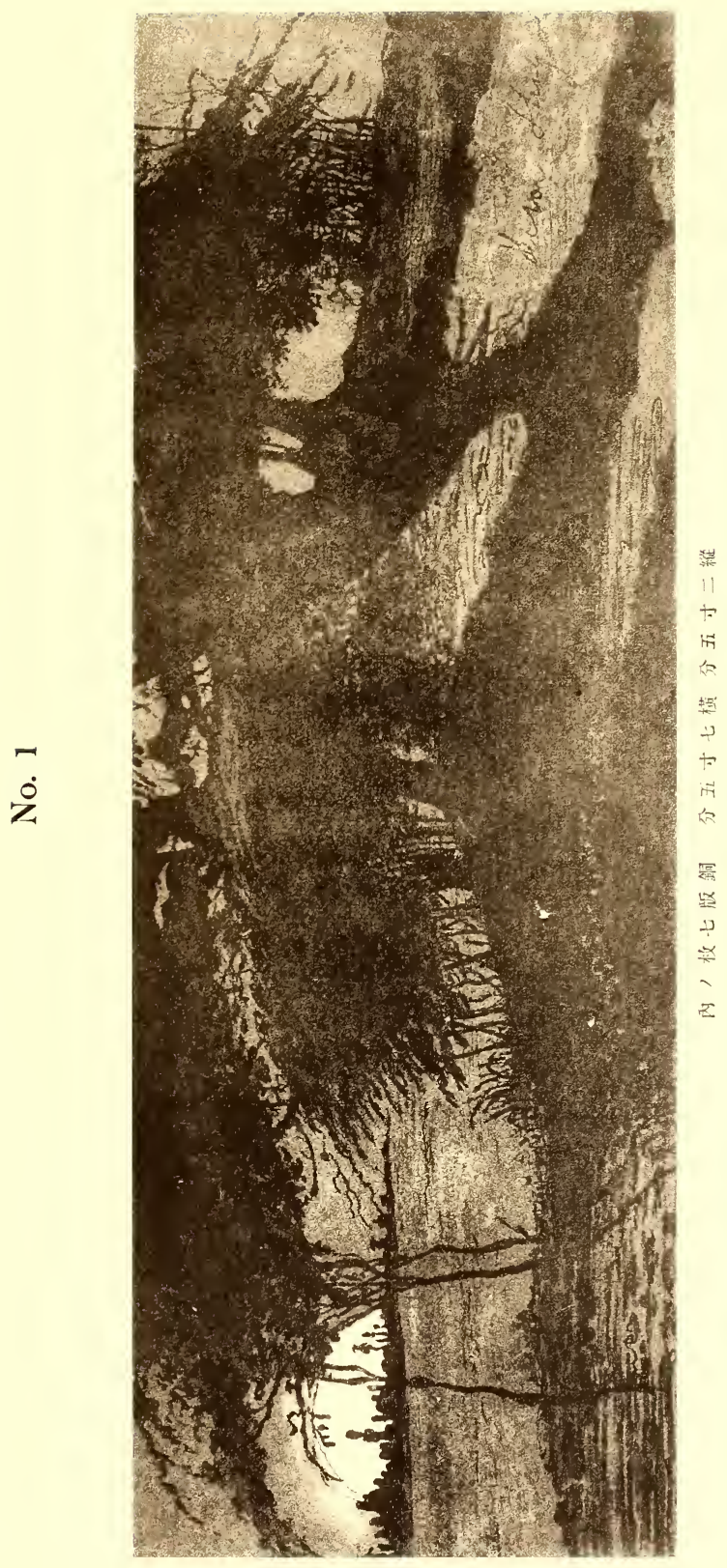


No. 1

\section{PAUL CHENAY \\ FRENCH \\ 1818-1906}

IMICA SILENTIA

$$
\text { Print }
$$

Height, 23/4 inches; length, 8 inches

After Victor Hugo. A romantic view of the sunset hour. Light departing, and the landscape given to silence and peace. 
No. 2

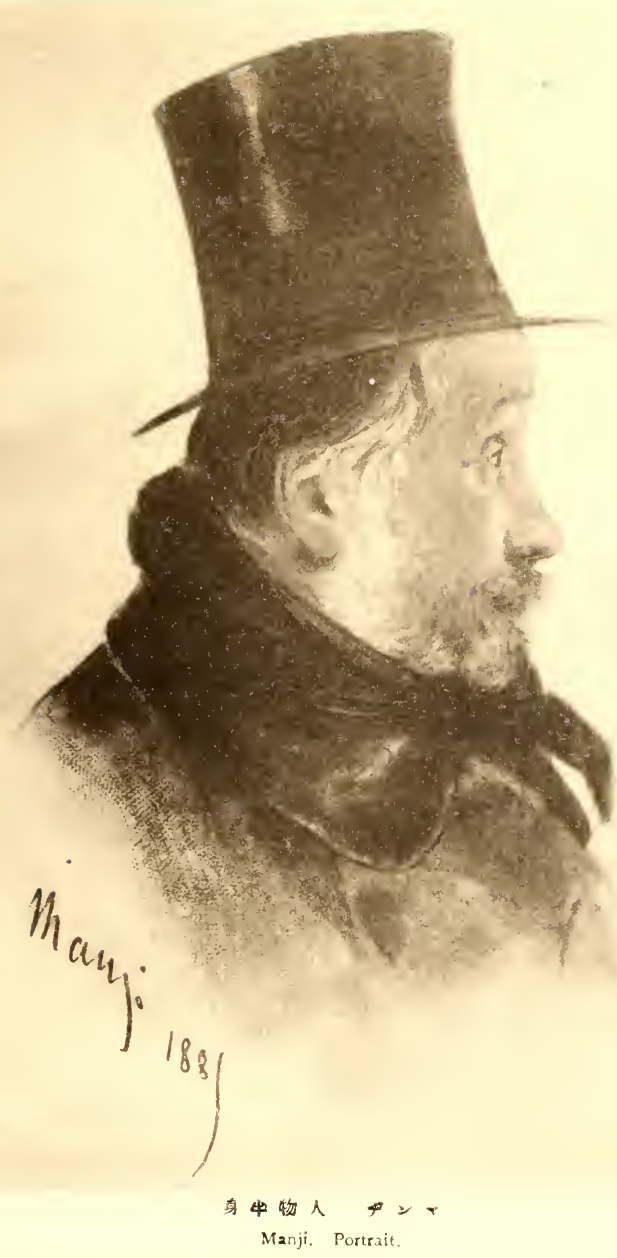


No. 2

\section{MANZI}

FRENCH

\section{A PORTRAIT'}

\section{Hcight, $5 \frac{1}{2}$ inches; zidth, 4 inches}

A FINE and living likeness or portrait of a man, in black and white, heightened by pink flesh tones. He is seen head and shoulders, in profile, facing the right, and wearing a silk hat, with a blue throat muffler above his great coat.

Signed at the lower left, Manzi, 1881. 
No. 3

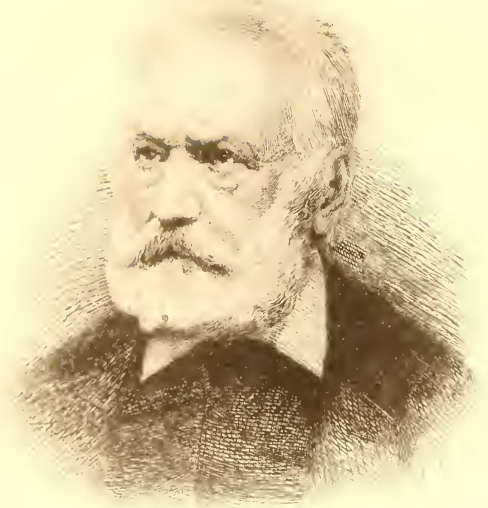

Abot, Victor Hugo.

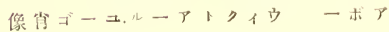


No. 3

\section{EUGENE MICHEL JOSEPII ABO'T}

BELGIAN

1836-1894

POR'TRAIT OF VICTOR HUGO

Etching

Height, 6 inches; width, $\$$ inches

Hran and shoulders of the French poet and novelist, facing to the left, three-quarters front, his eyes directed upward.

Signed at the lower right, E. Abot, aqua f. 


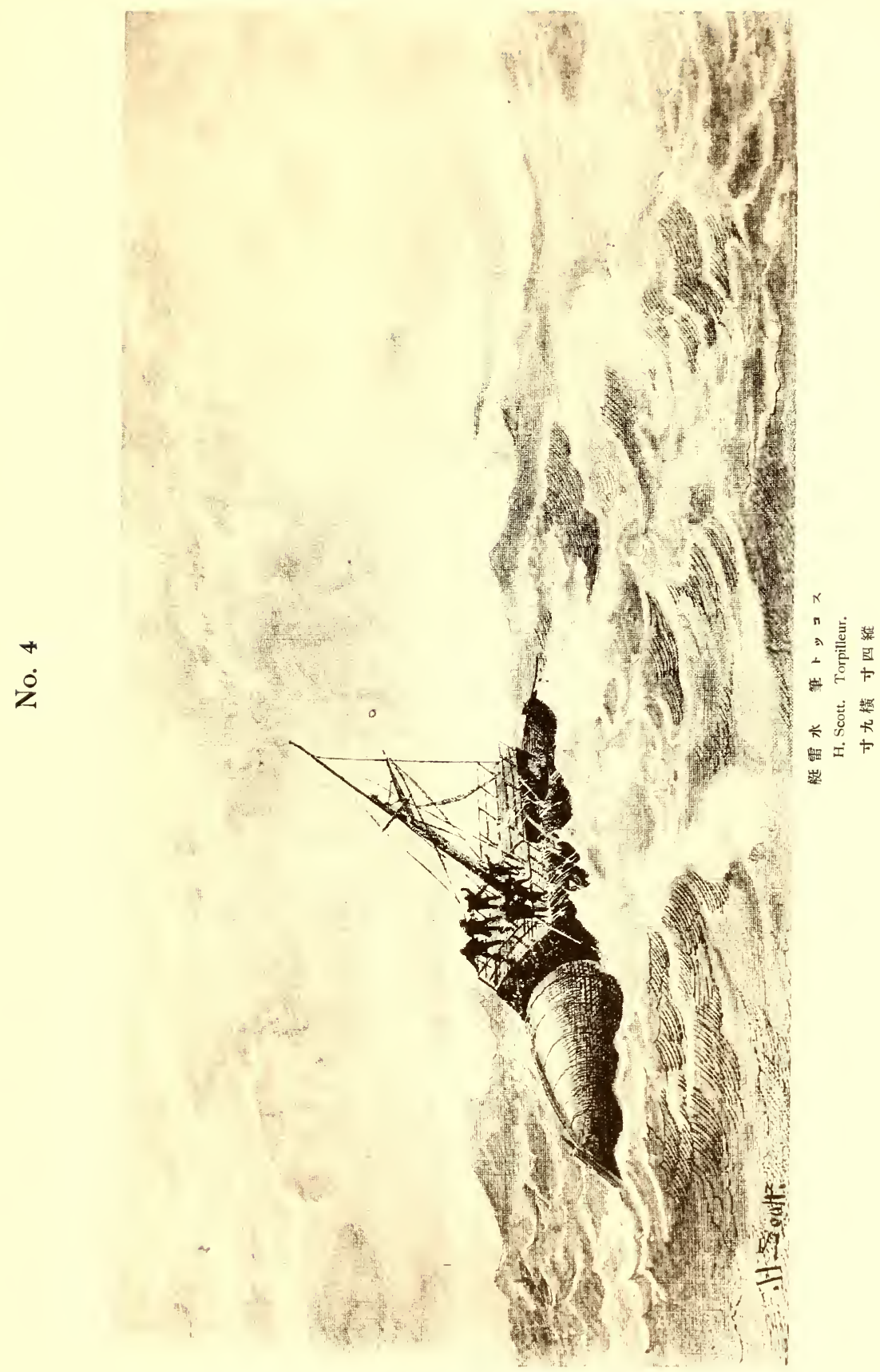


No. 4

\section{H. SCOTT}

\section{FRENCH}

Contemporary

TORPILLEUR

Black and White

Height, 5 inches; length, 11 inches

A TORPEDo boat is making rough weather of it in a choppy sea. Several men are on the slanting deck, and a steamer, with sails, is seen in the distance.

Signed at the lower left, H. Scott. 
No. 5

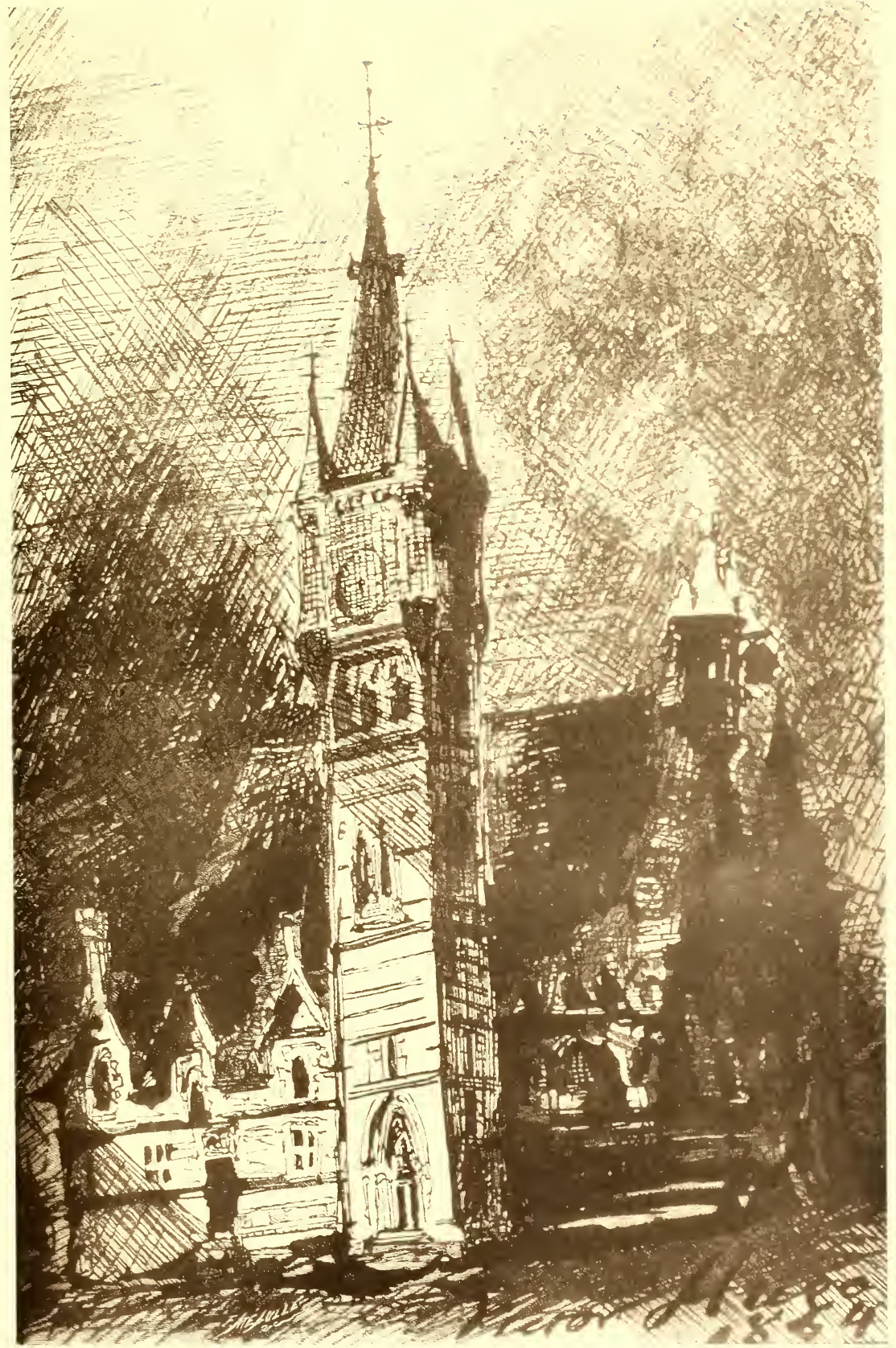

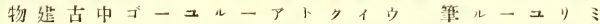

Milulle. Victor Hugo, Maison du moyen-àge.

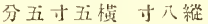


No. 5

F. MÉACLLE

FRENCH

Contemporary

MAISON DU MOYLYN AOEL

Print

Height, 93/4 inches; width, $6^{1}{ }_{2}$ inches

ArTer Victor Hugo. Apparently a combination church and dwelling, or one of the buildings of ecclesiastical architecture used for residence, with a tall clock tower in a brilliant light and the mass of the building in deep shadow. The Middle Ages seen in the Nineteenth century.

Signed at the lower left, F. Méaulle, sc. 


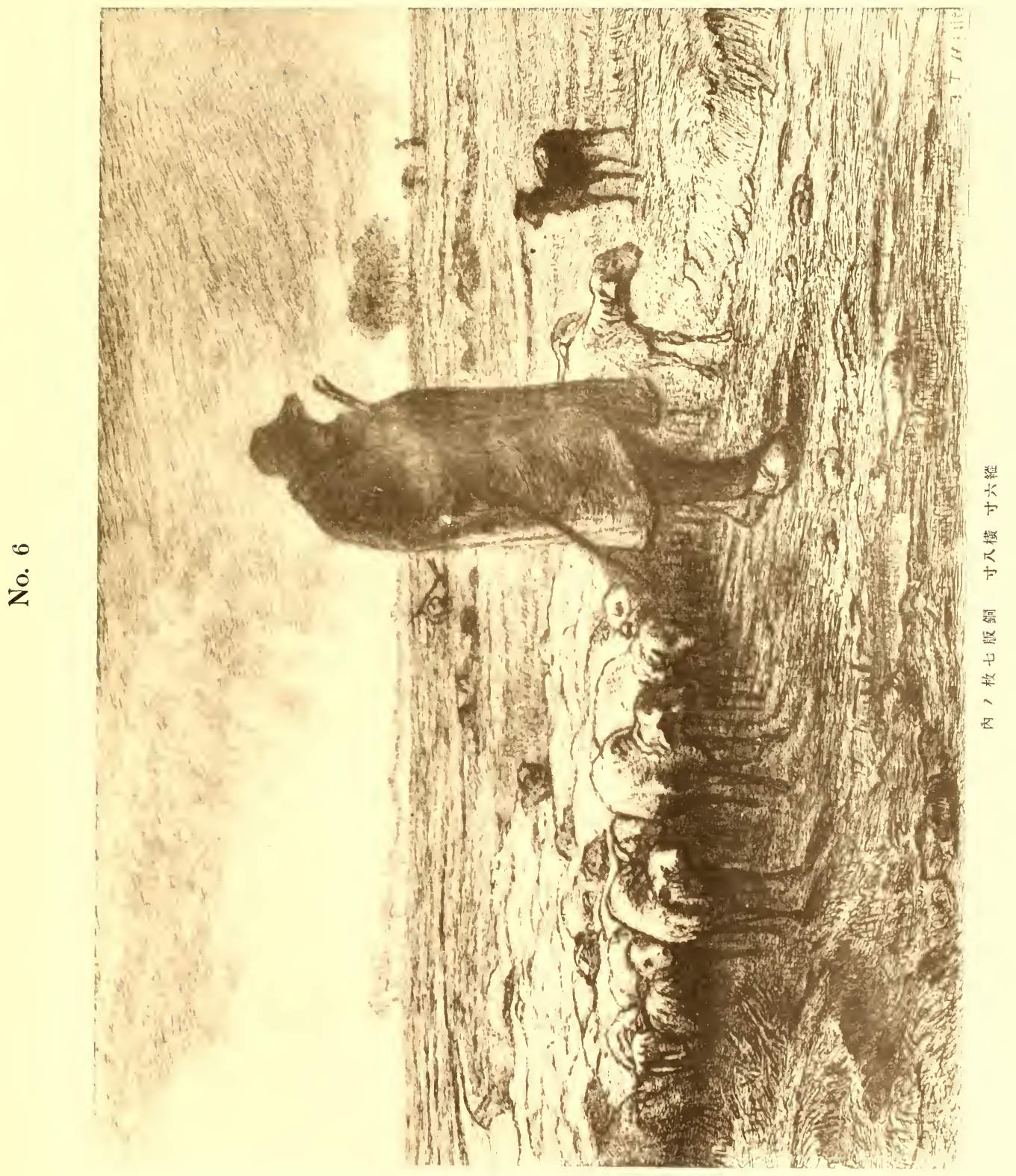


No. 6

\section{GUS'TAVE GREUX}

FRENCH

Deceased

\section{LA RENTREE DU TROLPEAL}

\section{Print}

Height, $\mathrm{T}$ inches; length, 91/2 inches

Arter Jean François Millet. The familiar Millet peasant leading his sheep homeward, across a flat field.

Signed at the lower right, J. F. Millet. (Jean François Millet;

French, 1814-1875.) 
No. 7

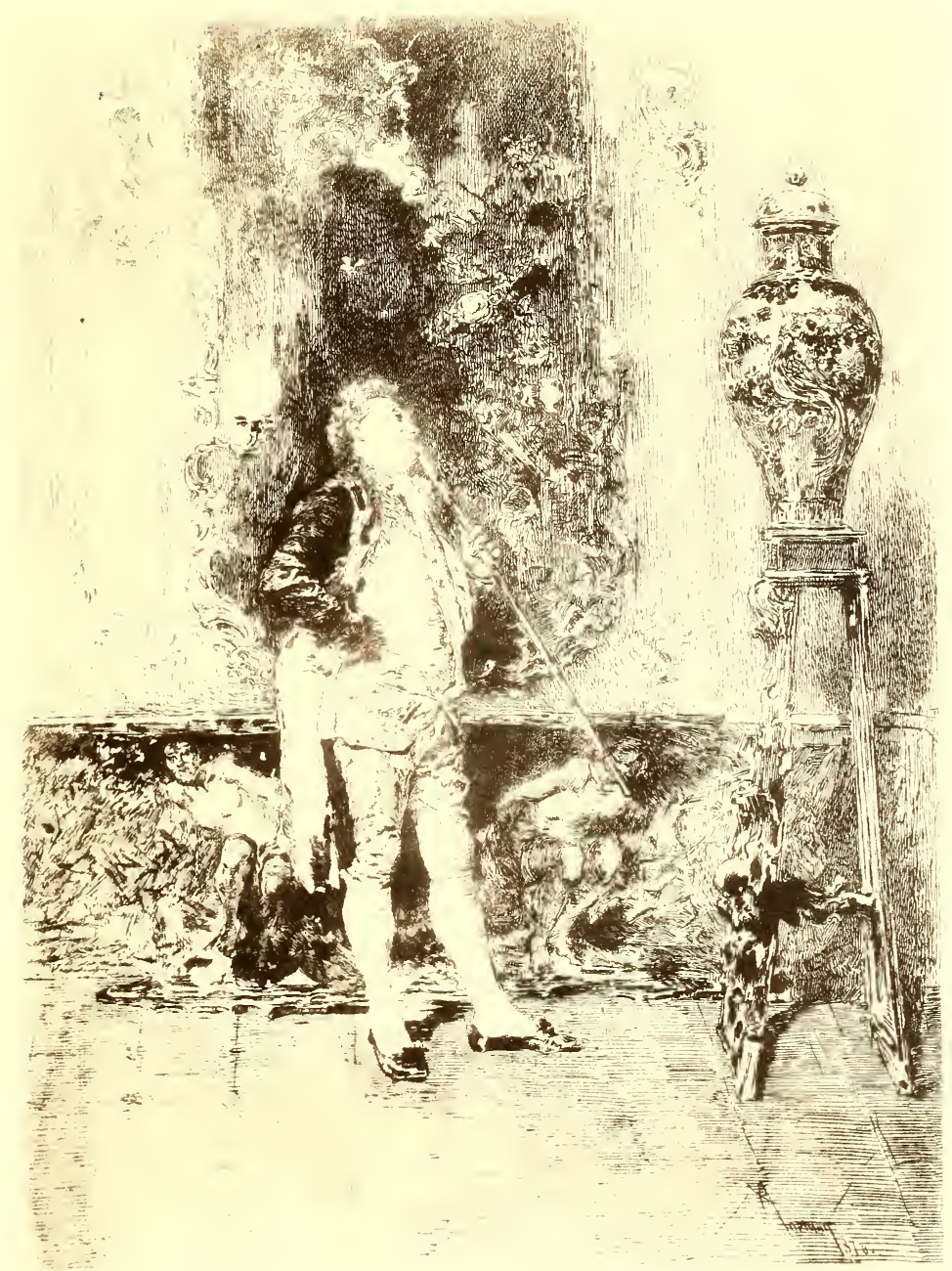

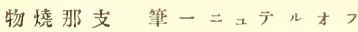

Fortuny. Vase de Chine,

寸六镭 寸八維 
No. 7

\section{CIARLIES WAL'TNER}

FRENCH

Contemporary

LE I ISE DE' CHINE

Engraving

Height, 93/4 inches; width, $\%$ inches

ArTER a pen drawing or etching by Fortuny of his own well-known picture in water color of an early exquisite admiring as a conmoisseur a tall Chinese rase in a palace, entitled "The Rare Vase."

The original water color, sold in the Mary J. Morgan collection, in 1886, is now in the W. T. Walters Galleries, Baltimore. 


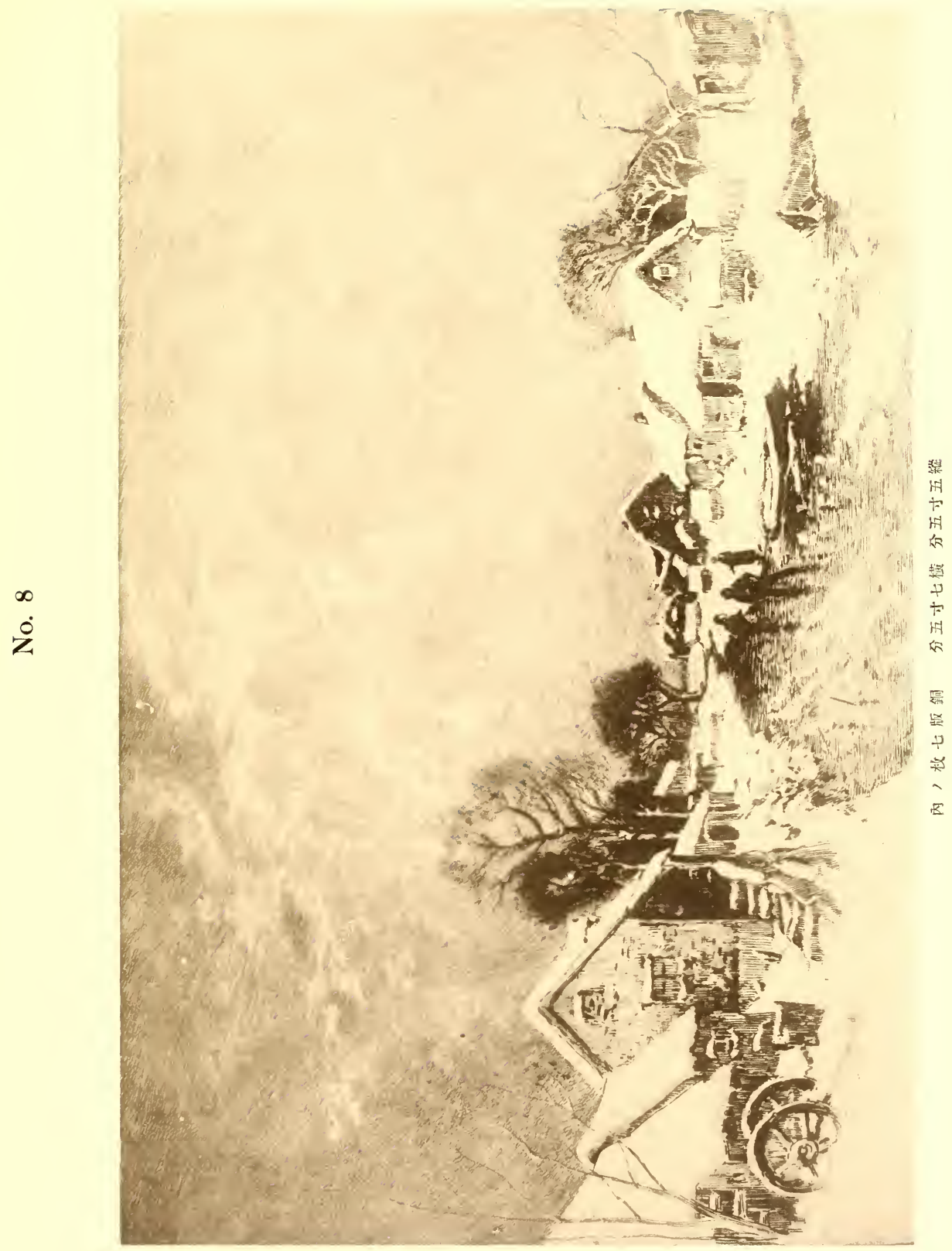


No. 8

THÉOPHILE CHAUVEL

FRENCH

1831 -

UN VILLAGE EN SUEDEE

Etching

Height, 6는 inches; length, 10 inches

AFTER Wilhelm von Gegerfelt (Swedish, 1844-). A group of dwellings on either side of a stream, all under deep snow. 


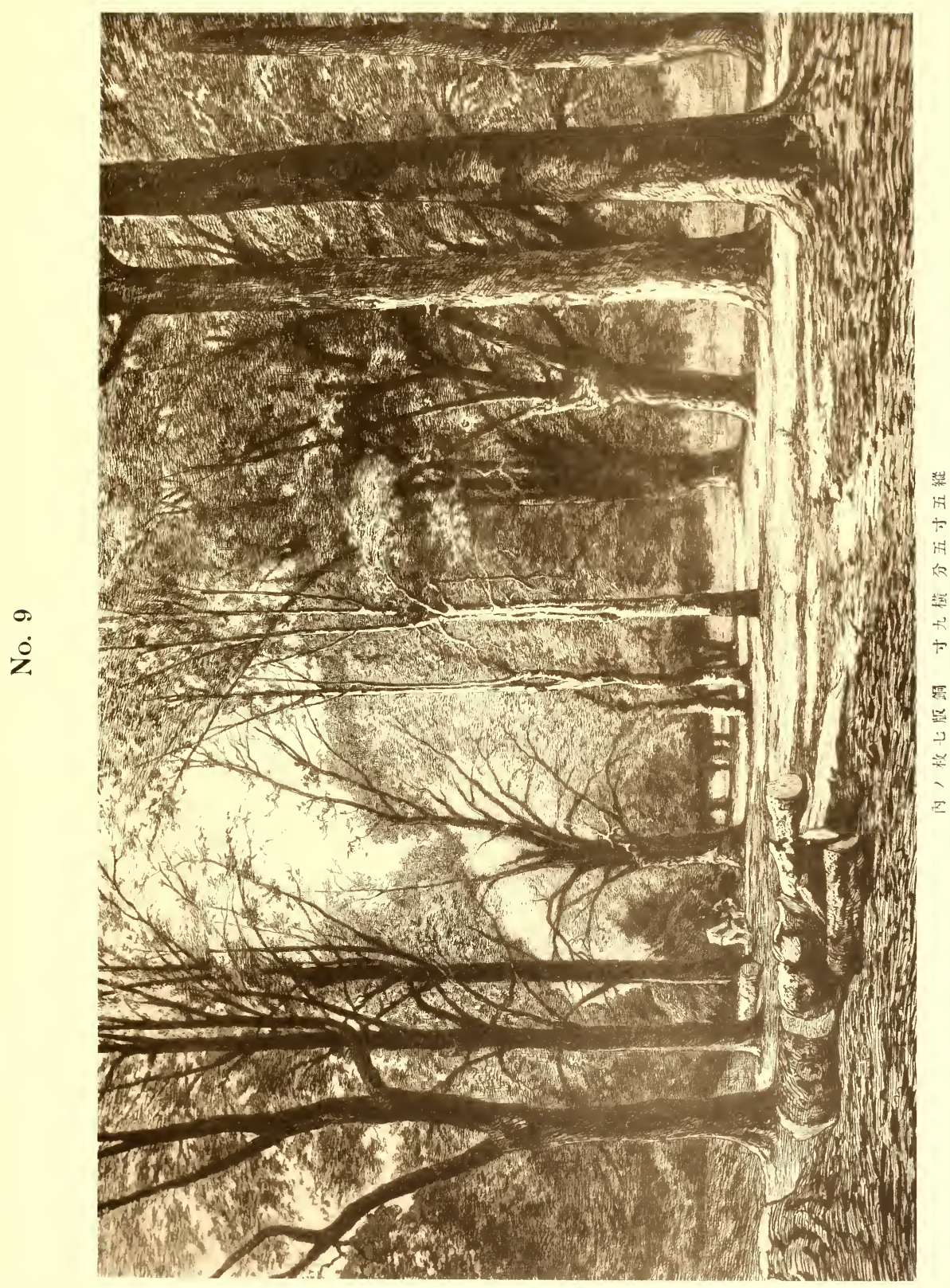


No. 9

\section{GUSTAVE GREUX}

\section{FRENCH}

Deceased

\section{SABOTIERS DANS LE BOIS DE QUIMERC'H (FINISTE'RE)

$$
\text { Print }
$$ \\ Height, 61/2 inches; length, 101/2 inches}

Arten Camille Bernier (French, 1823-). A large tree has been felled, in an open forest, and sawn into logs, which lie in the foreground. In the middle distance the sabots makers are at their work or resting. 
$\frac{1}{2}$

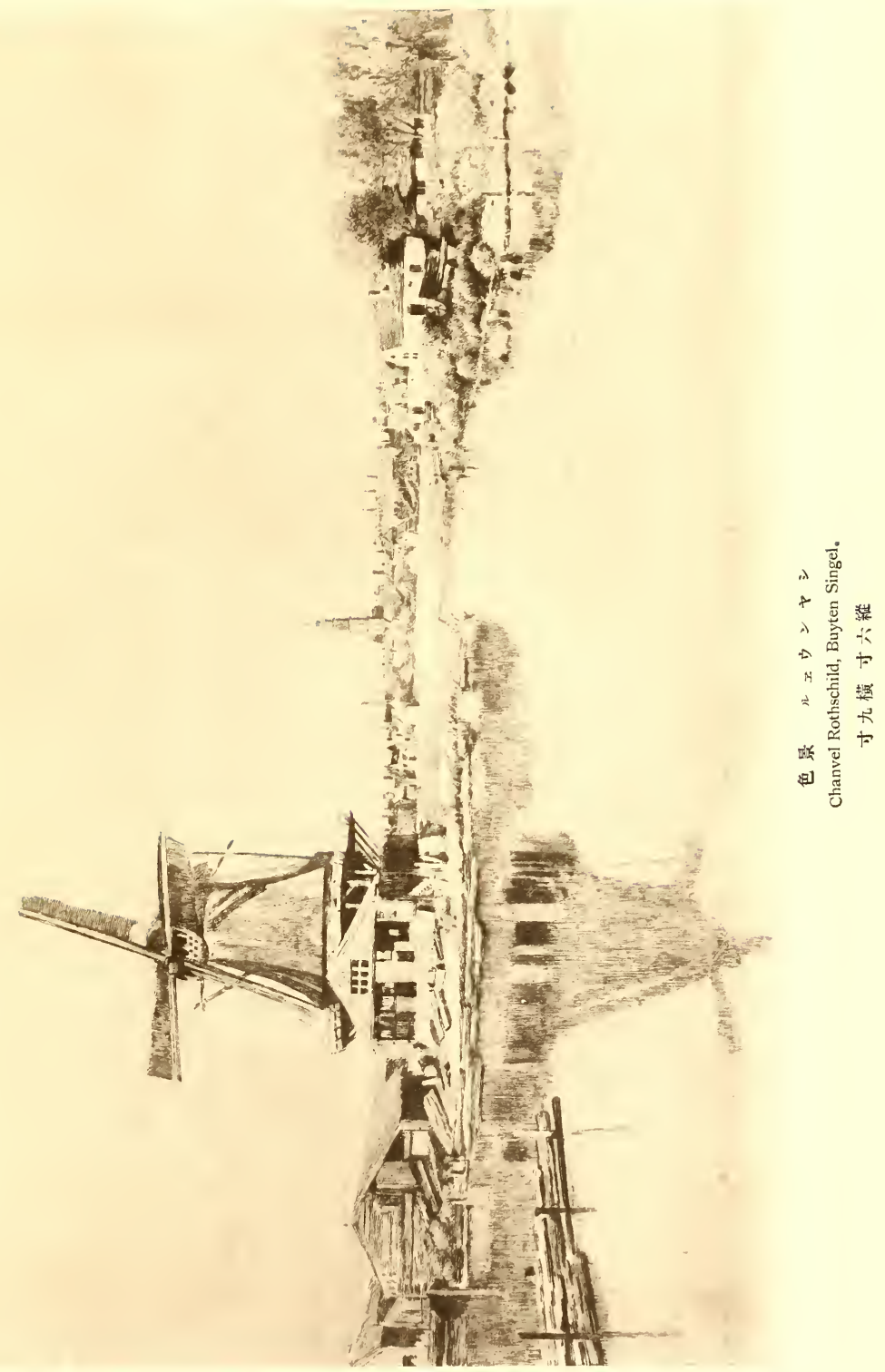


No. 10

\section{THÉOPHILE CHALVEL}

FRENCH

1831-

BUITEN SINGLE, AMSTERDAM

Print

Height, 71/2 inches; length, 11 inches

After la Baronne Nathaniel de Rothschild (FrenchContemporary). A view of the Dutch city, with a great windmill near the foreground, the whole seen across two arms of a placid river-or possibly a canal or an inletwhich carries reflections of the shore edges and the windmill. 


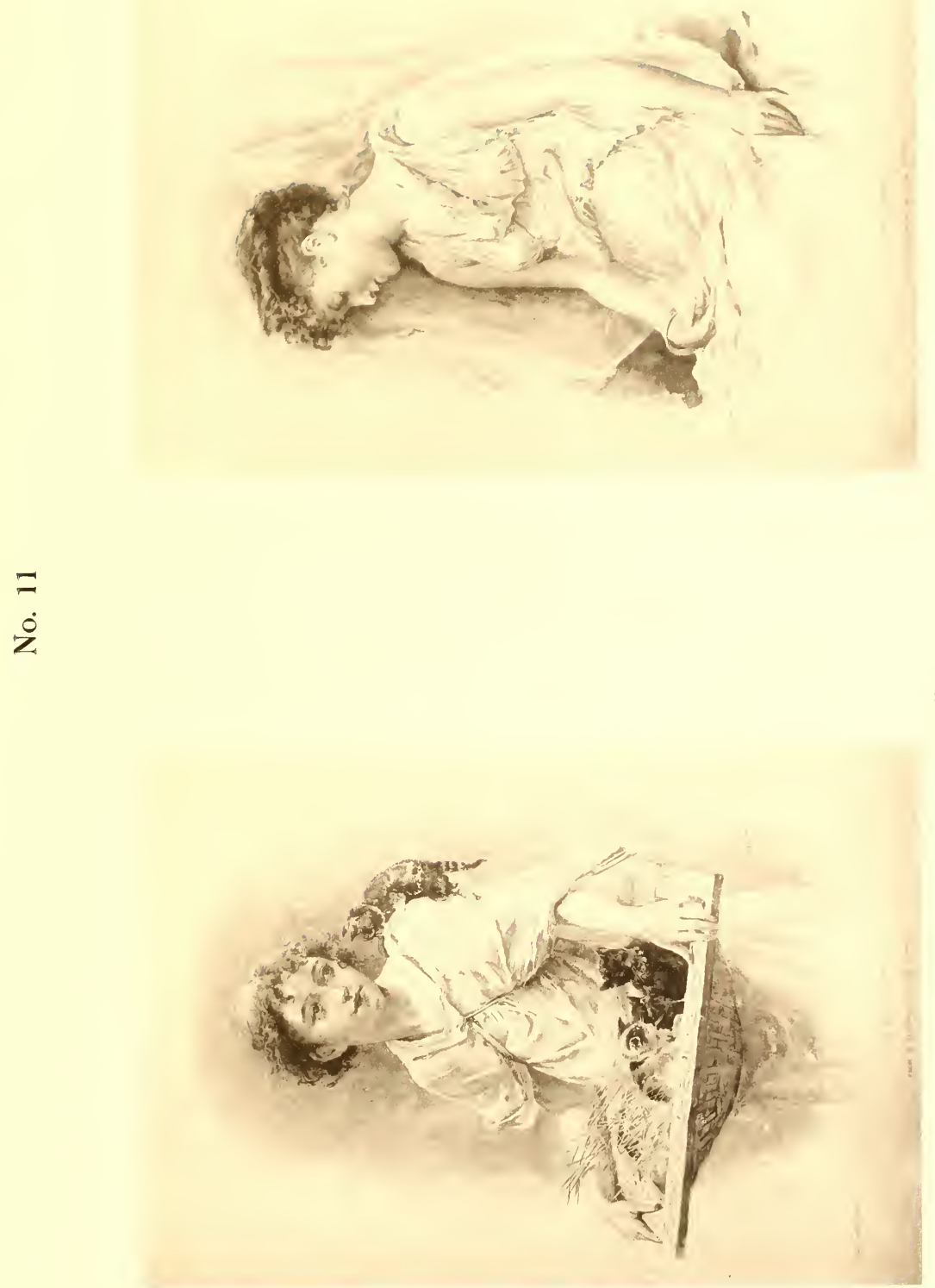


No. 11

\section{ALICE HAVERS}

\section{DELC FILLES}

Process Reproductions

Height, 12 inches; width, $71 \%$ inches

Two reproductroxs from water color drawings by Alice Havers; subjects, "Wide Awake" and "Fast Asleep." In "Fast Asleep" is pictured a young woman sitting back against the portières, dreaming. In the companion picture a young girl, quite awake, with a kitten playing on her shoulder, is carrying a tray holding more small kittens.

"Wide Awalie" signed at the lower right, A. H. 


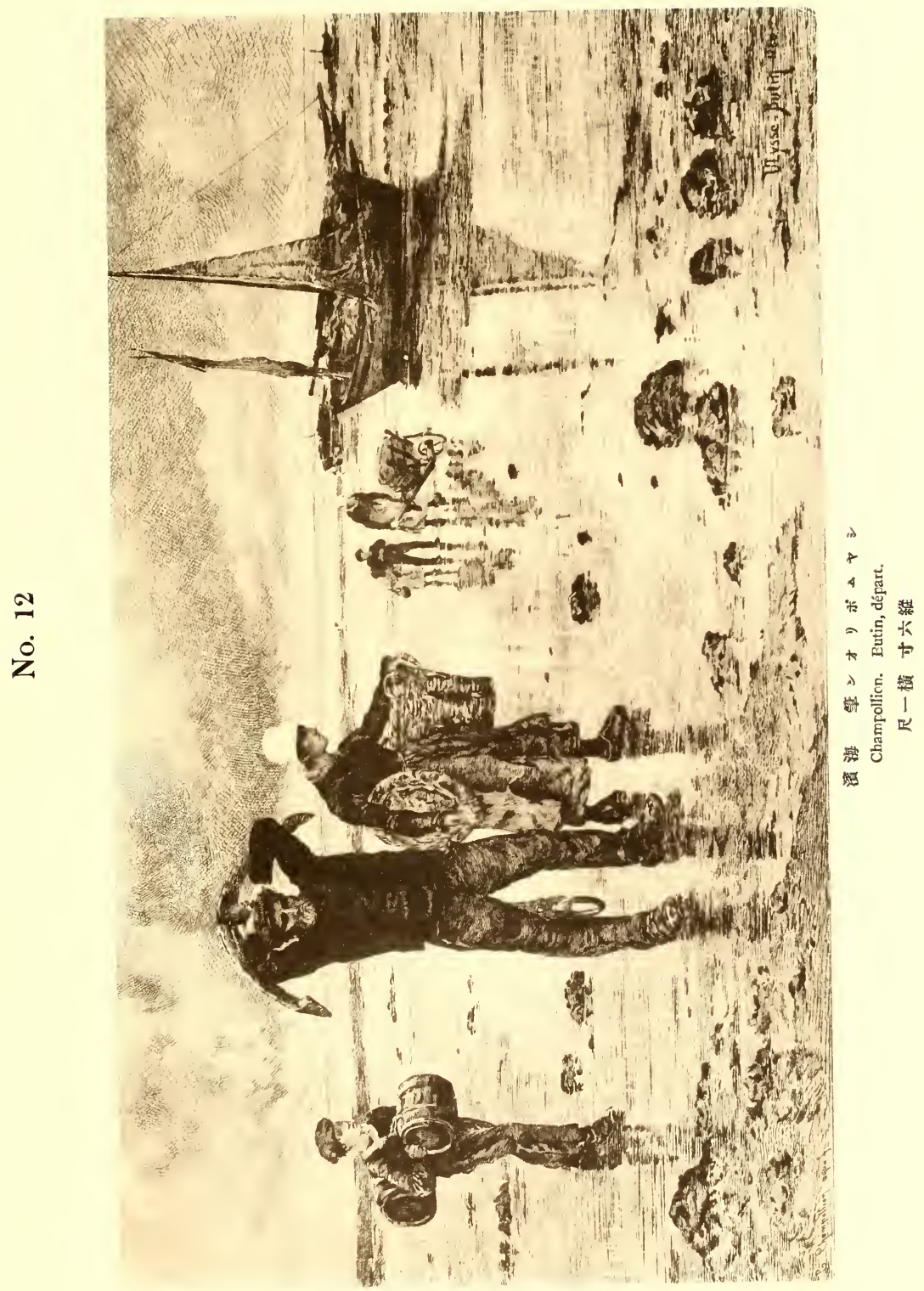


No. 12

EUGENE ANDRÉ CHAMPOLLION

FRENCH

1848-1901

\section{LE DÉPART}

Etching

Height, 7 inches; length, 111/2 inches

After Ulysse-Butin. (Louis Auguste Ulysse-Butin;

French, 1838-1883.) It is low tide on a flat coast, and fishermen and their families are making ready for the next sailing, carrying water casks, etc, over the wet sands toward and from the boats.

Signed at the lower left, E. Champollion, aqua $f$. 


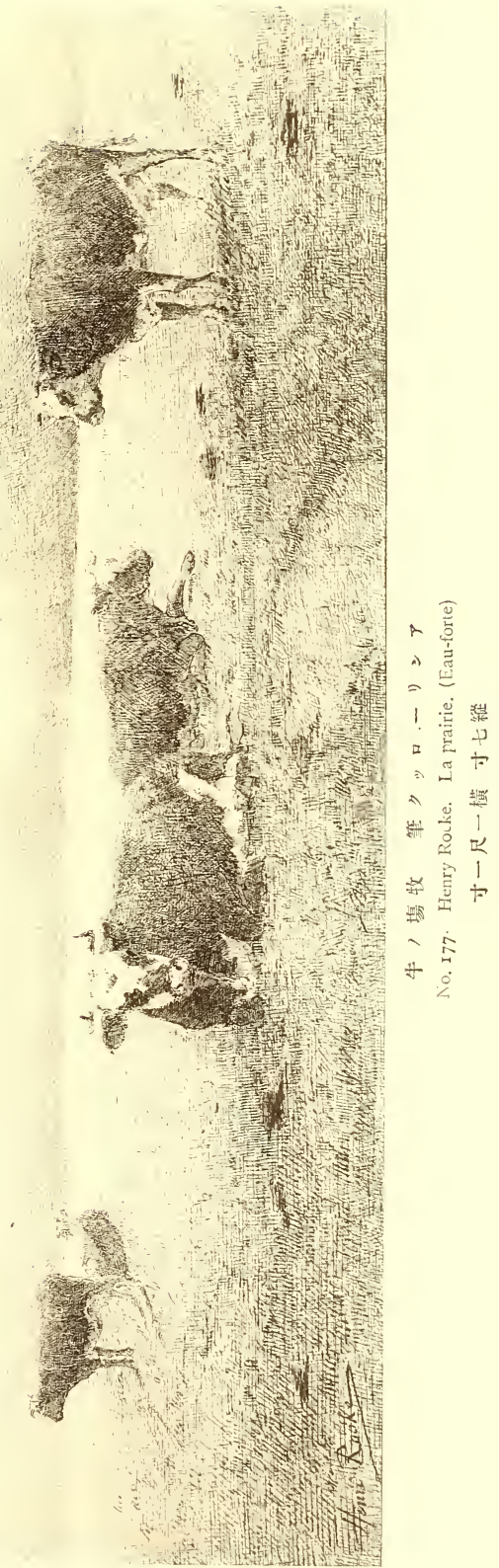


No. 13

HENRI ROOKE

\section{LA PRAIRIE}

Etching

Height, 8 inches; length, 13 inches

Five cows in different attitudes, forming a scattered group, three lying down, on a flat meadow at sunset.

Signed at the lower left, Henri Rooke. 


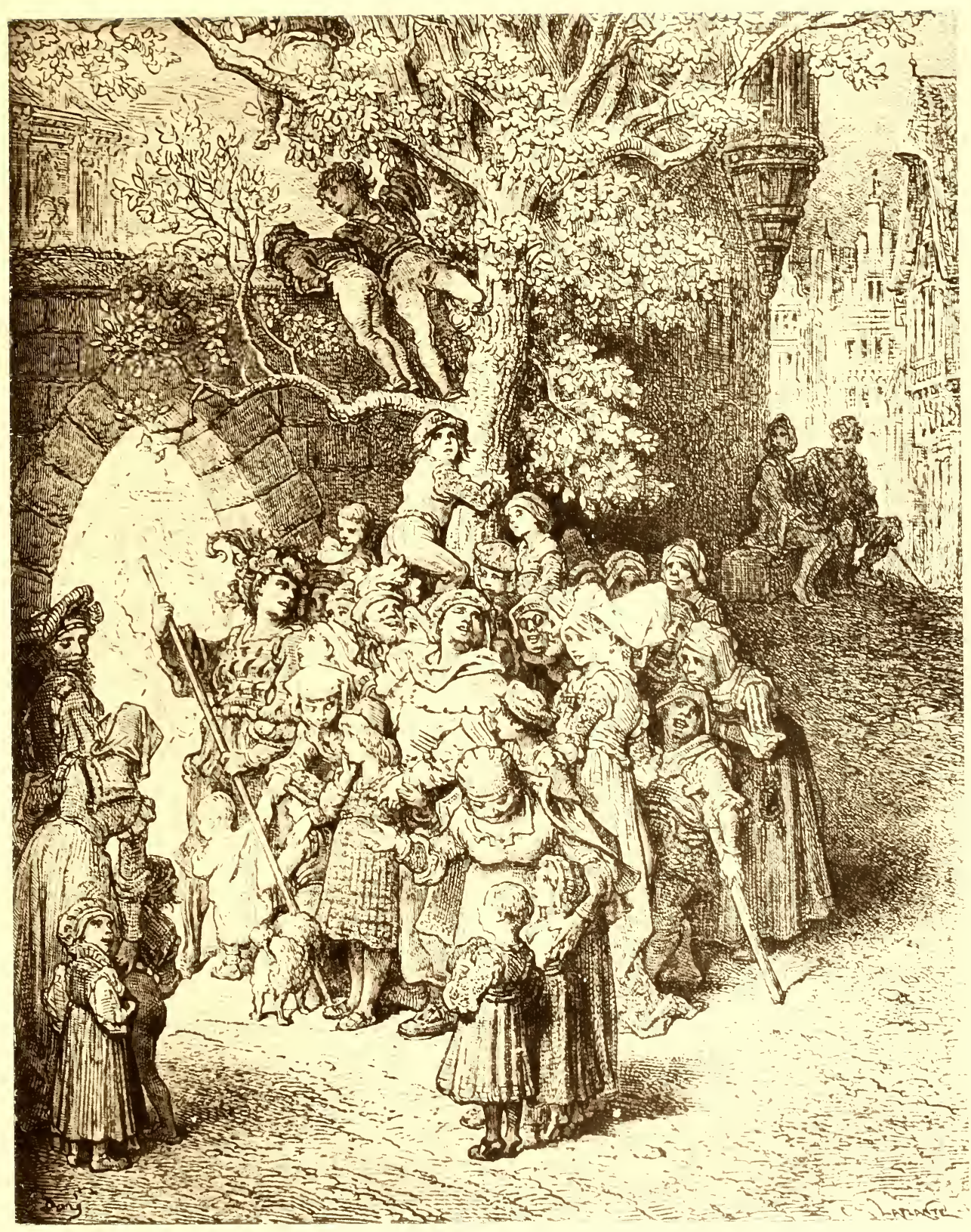

繪史歷箕一レ一ト 
No. 14

C. LAPLAN'TE

FRENCH

"OLD MARINER"

Wood Engraving

Hcight, 113/4 inches; width, 9 inches

AFTer Gustave Doré. A proof of an engraving on wood by C. Laplante after Doré, which has been "touched up" for reproduction. 'The picture is of a motley group of men, women and children, gathered about the gateway of an ancient castle wall.

Signed at the lower right, C. Laplante. 


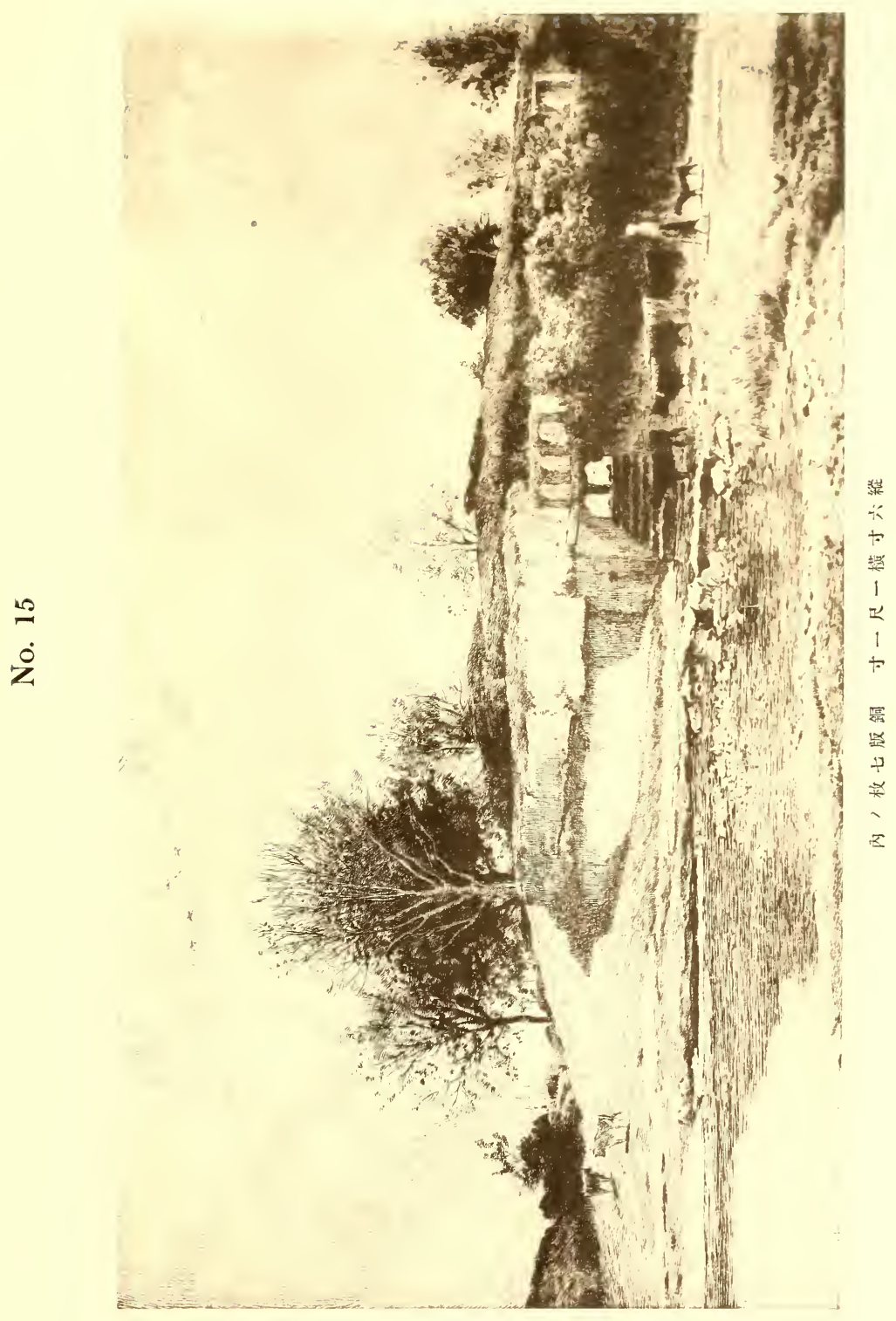


No. 15

\section{THEOPHILE CHAUVEL}

FRENCH

1831 -

UNE ECLUSE DANS LA VALLEE D'OPTEIOS' (ISĖRE)

Ftching

Height, 7 inches; length, 13 inches

AFTER Daubigny. What appear to be ruins are visible at the side of a hill, in connection with a sluice through which a stream descends to the valley in the foreground. A girl and her dog have driven some cows down to the water here, to drink, and on the farther bank of the stream other cattle are seen. From a painting by C. F. Daubigny which hung in the Luxembourg. 
No. 16

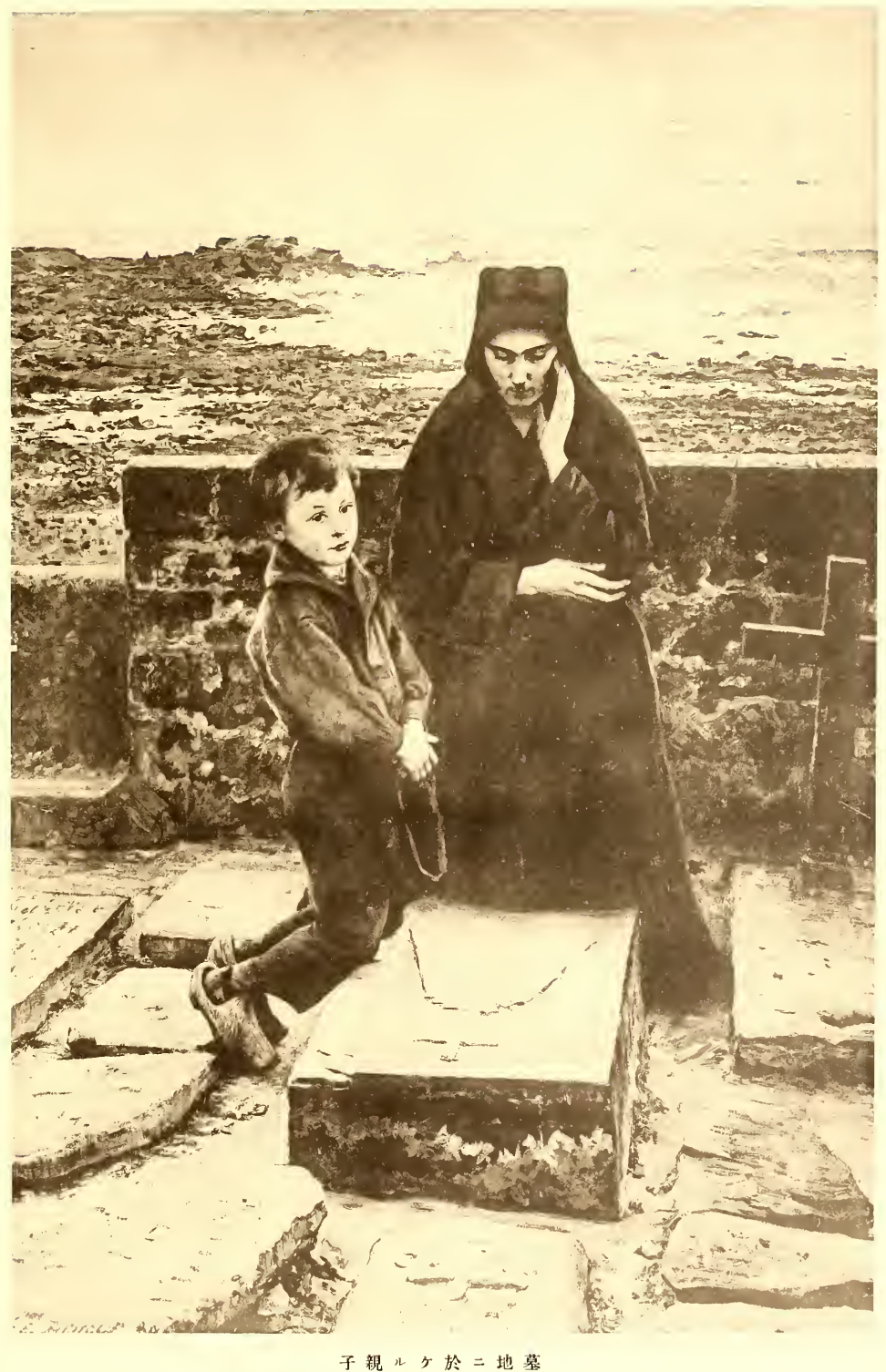

Mère et enfant sur un Tomdeau.

寸七横才一尺一粚 
No. 16

\section{UNKNOWN}

MÉRE ET ENFANTSUR UN TOMBEAU

$$
\text { Print }
$$

Height, 131/2 inches; width, 81/2 inches

A mother in black kneels at the foot of a tombstone, over a grave in a cemetery, her small son kneeling, with his hat in his hand, at the side.

Signature at the lower left undecipherable. 
No. 17

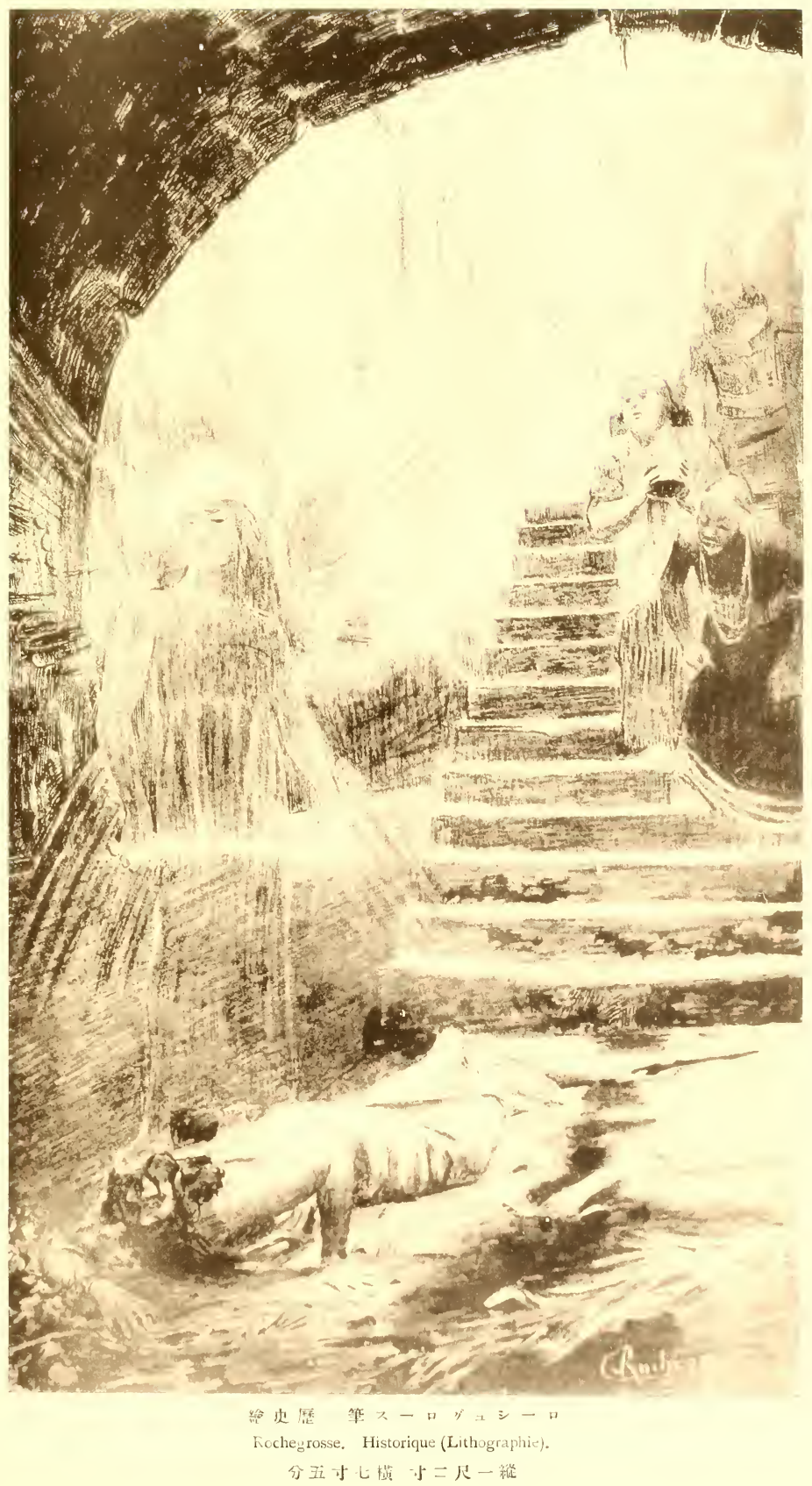


No. 17

\section{GEORGES ROCHEGROSSE}

FRENCH

Contemporary

HISTORIQUE

Lithograph

Height, 141/2 inches; width, 9 inches

ONe of the artist's Babylonian creations. The appearance of the avenging angel of the Lord with a luminous sword has stricken down the Oriental potentate, at the foot of a stairs under a dark arched entrance of an Easterı building, while people look down, awe-struck, from the street aloft.

Signed at the lower right, G. Rochegrosse. 
No. 18

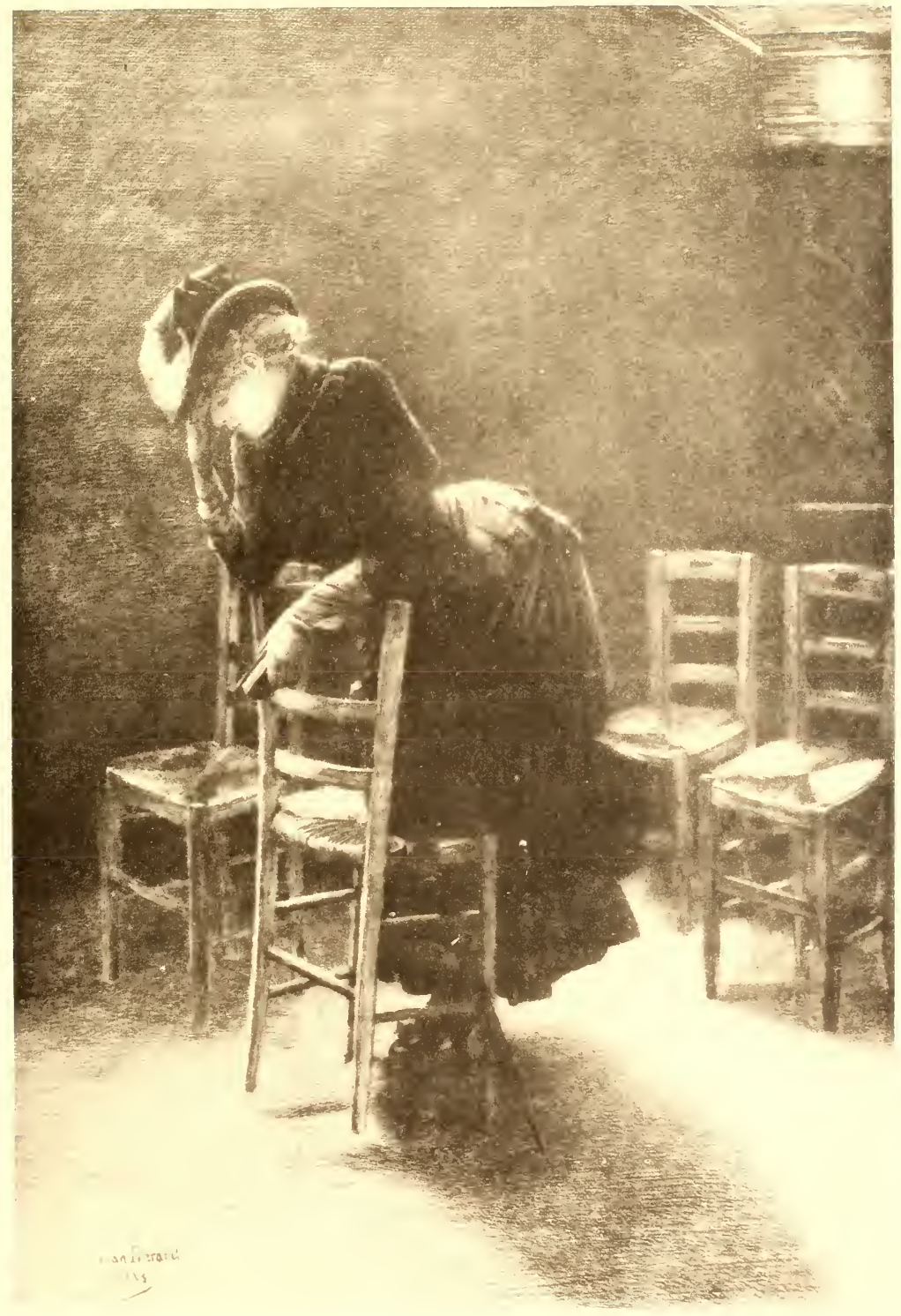

内，枚七版铜分五寸八獚分五寸二六一链 
No. 18

\section{DANIEL MORDAN'T FRENCH \\ Contemporary}

LA PRIERE

Print

Height, 15 inches; width, 10 inches

After Jean Beraud. A woman in the dress of the early '80's, leaning over a chair, at prayer, in a European church. 
No. 19

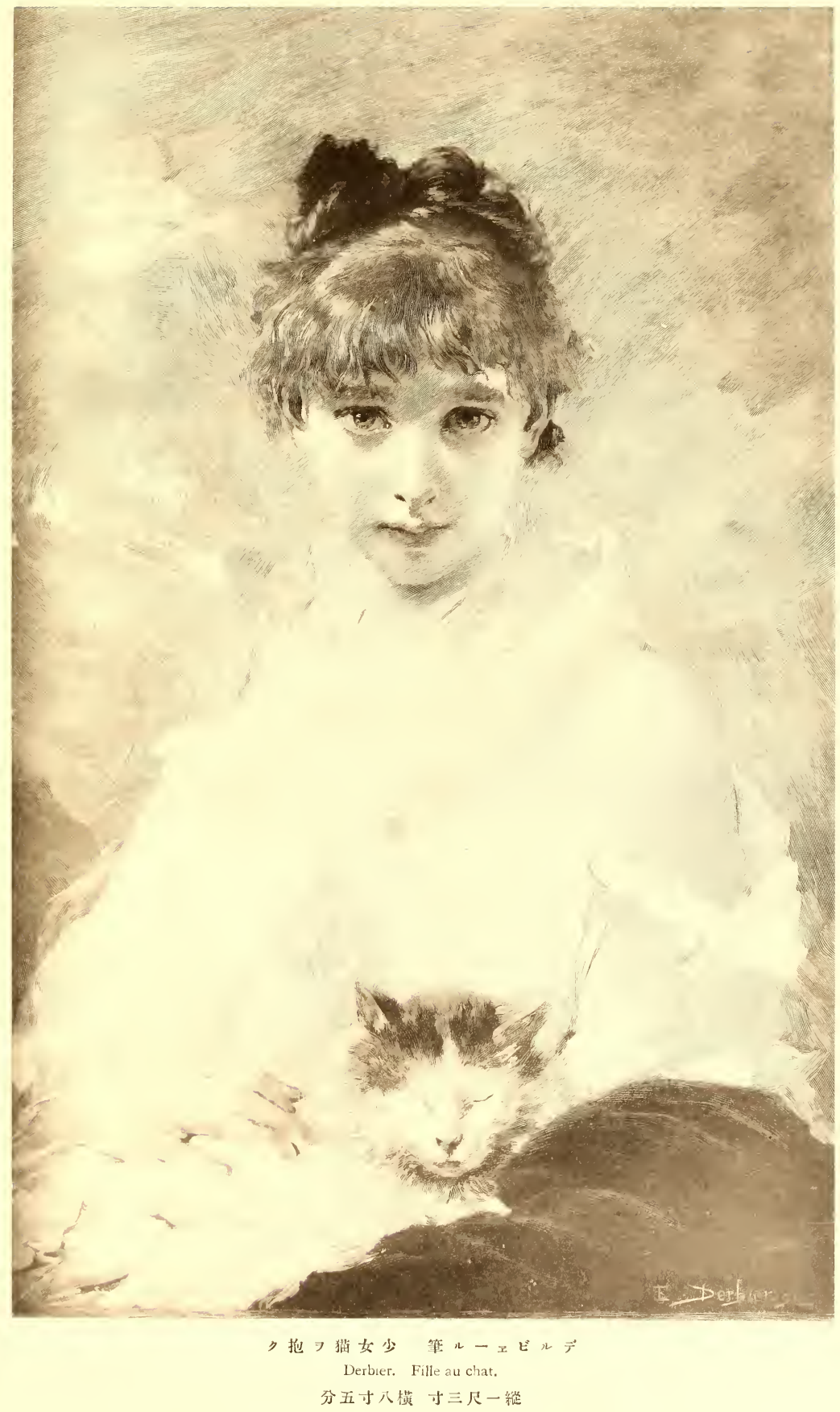


No. 19

\section{E. DERBIER}

FRENCH

Contemporary

FILLE AU C'HAT

Wood Engraving

Height, 151/.2 inches; width, 10 inches

A LARGE-ExED, pretty, pensive girl, seated and turned to the left, is facing the spectator fully, directly and thoughtfully, as she holds in her arms a large cat, which appears to be a Persian, that has gone to sleep. Three-quarter length. After Chaplin's well-known painting. On fine Japan paper.

Signed at the lower left, E. Derbicr, se. 
No. 20
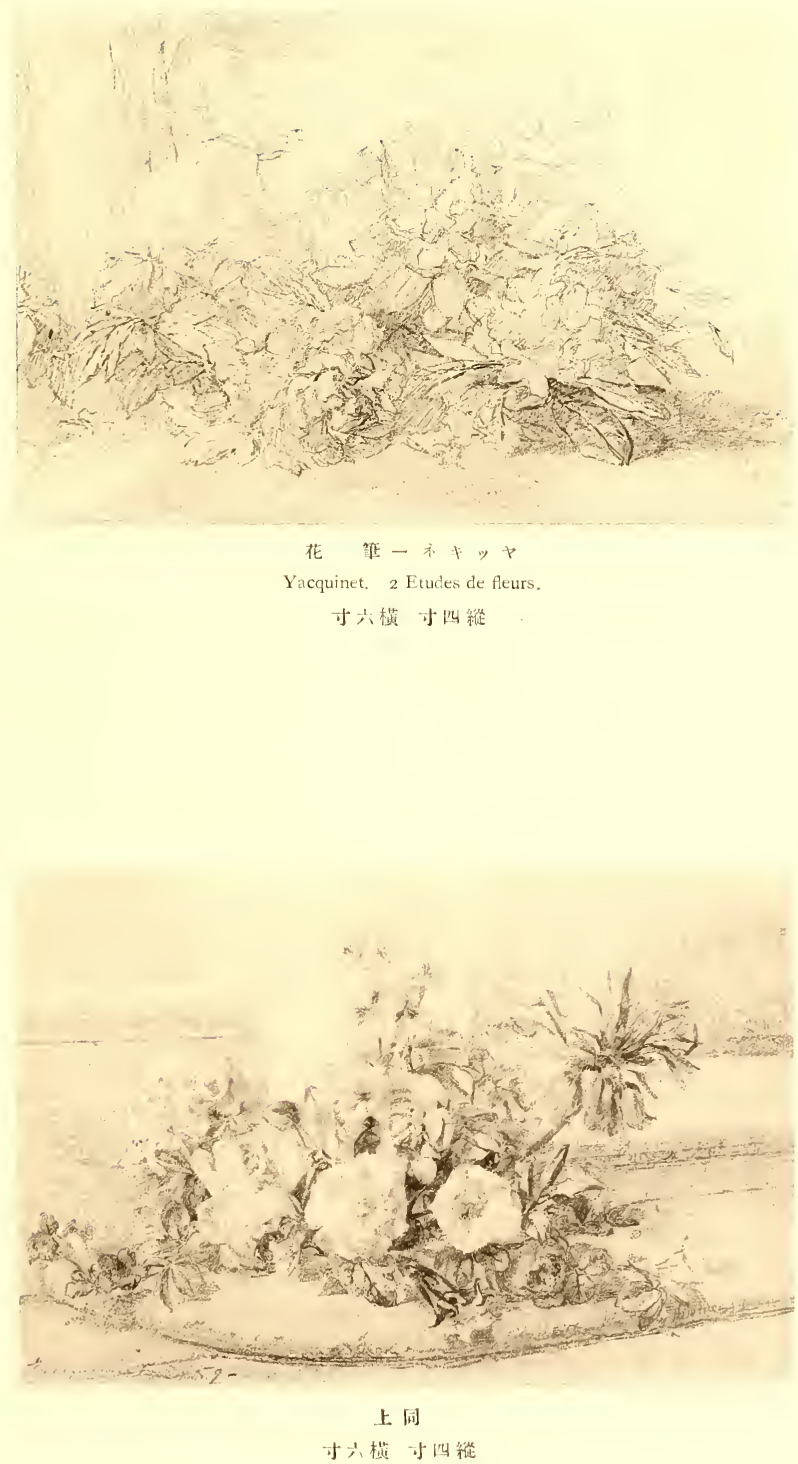
No. 20

M. F. JACQUE'T'TE

DEUT ÉTUDES DE HLEURS

Pencil Sketches

Each, height, $4^{1}$ inches; length, 63/4 inches

Two flow Er studies on one board - one, a mass of flowers growing wild about the foot of a tree trunk; the other, growing flowers arranged at the foot of a large column on a terrace.

Lower study signed at the low'r left, F. Jacquette. 


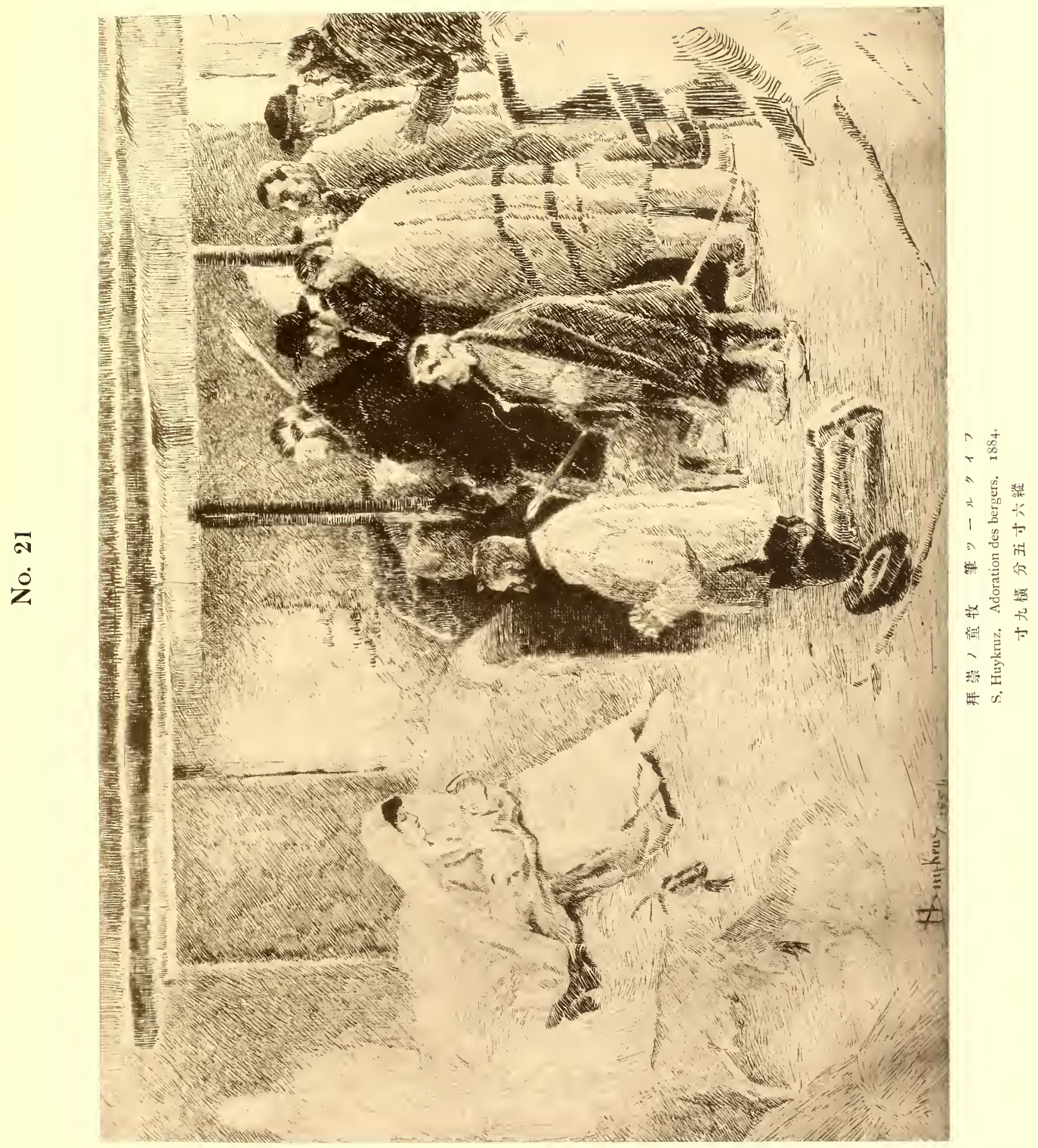


No. 21

\section{S. HUYKRUZ}

\section{ADORATION DES BERGERS}

Black and White

Height, $73 / 4$ inches; length, 101/2 inches

ON a mound of straw in a lowly stable the Virgin is seated, with the Child in her arms. Before her the shepherds are kneeling and standing, and the stable animals are seen at the sides of the building.

A pen-and-ink drawing, with gouache used for the faces of the shepherds and for their staffs.

Signed at the lower left, S. Huykruz, 1884. 
No. 22

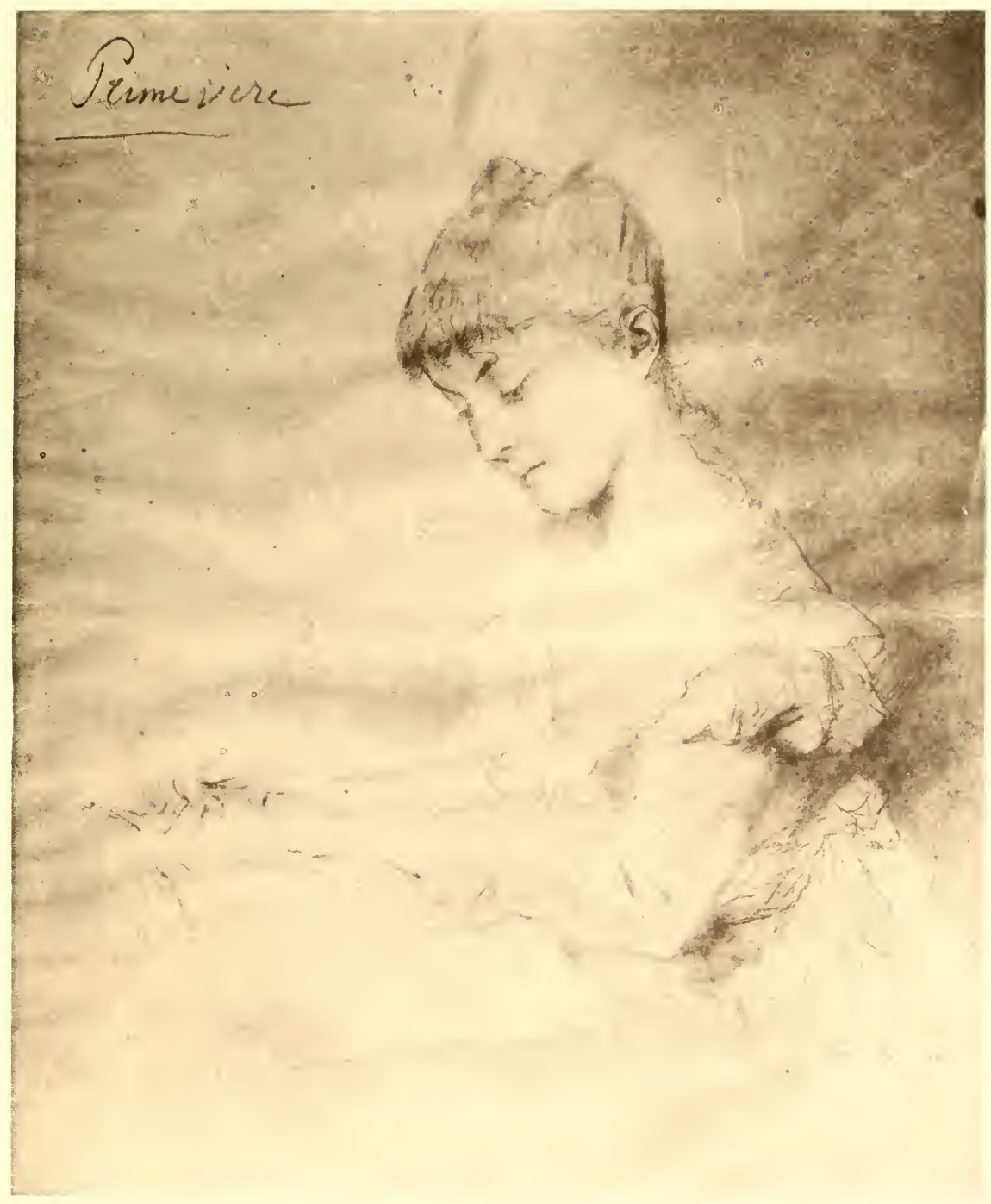

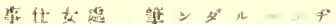

Jourdan, Primevère.

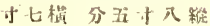


No. 22

\section{ADOLPHE JOURDAN}

FRENCH

1825-

\section{PRIMEV'̇RE}

\section{Drawing}

Height, 101/2 inches; width, 8 inches

A young girl of graceful features, sketched at threequarter length, seated, and facing toward the left, threequarters front. A large open volume lies in her lap, at which she is looking with interest.

Signed at the lower right, A. Jourdan. 


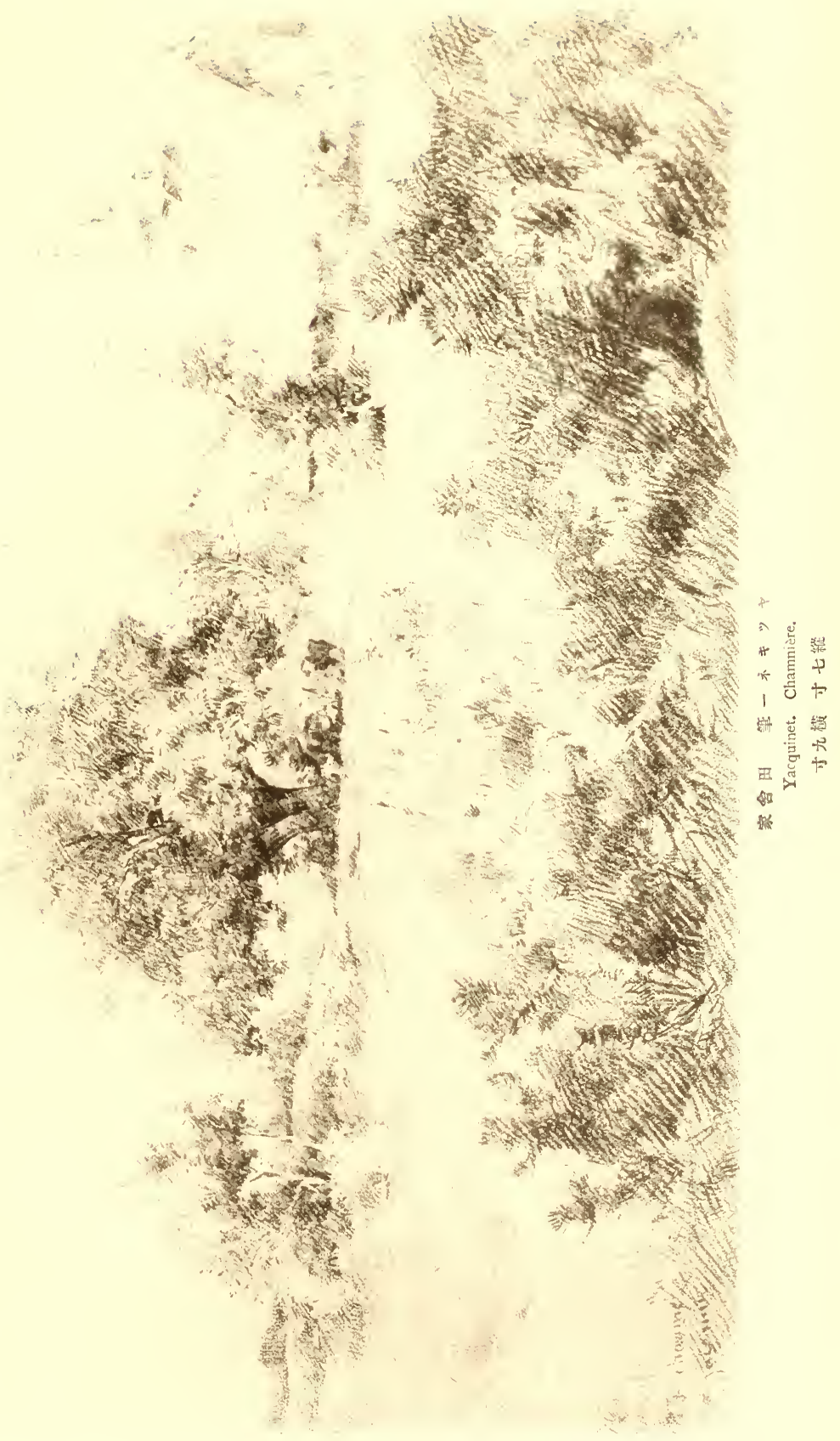


No. 23

\section{F. JACQUE'T'TE}

UNCIIAUME

Crayon-Black and White

Height, 71 - inches; length, 11 inches

Bushes, a field and a winding path from the foreground.

Beyond are some cattle grazing under a tree, and near by is a tall building with a low thatched roof.

Signed at the lower left, M. (or M F in a monogram) Jacquette, with the title, "I'n chanme." 


\section{No. 24}

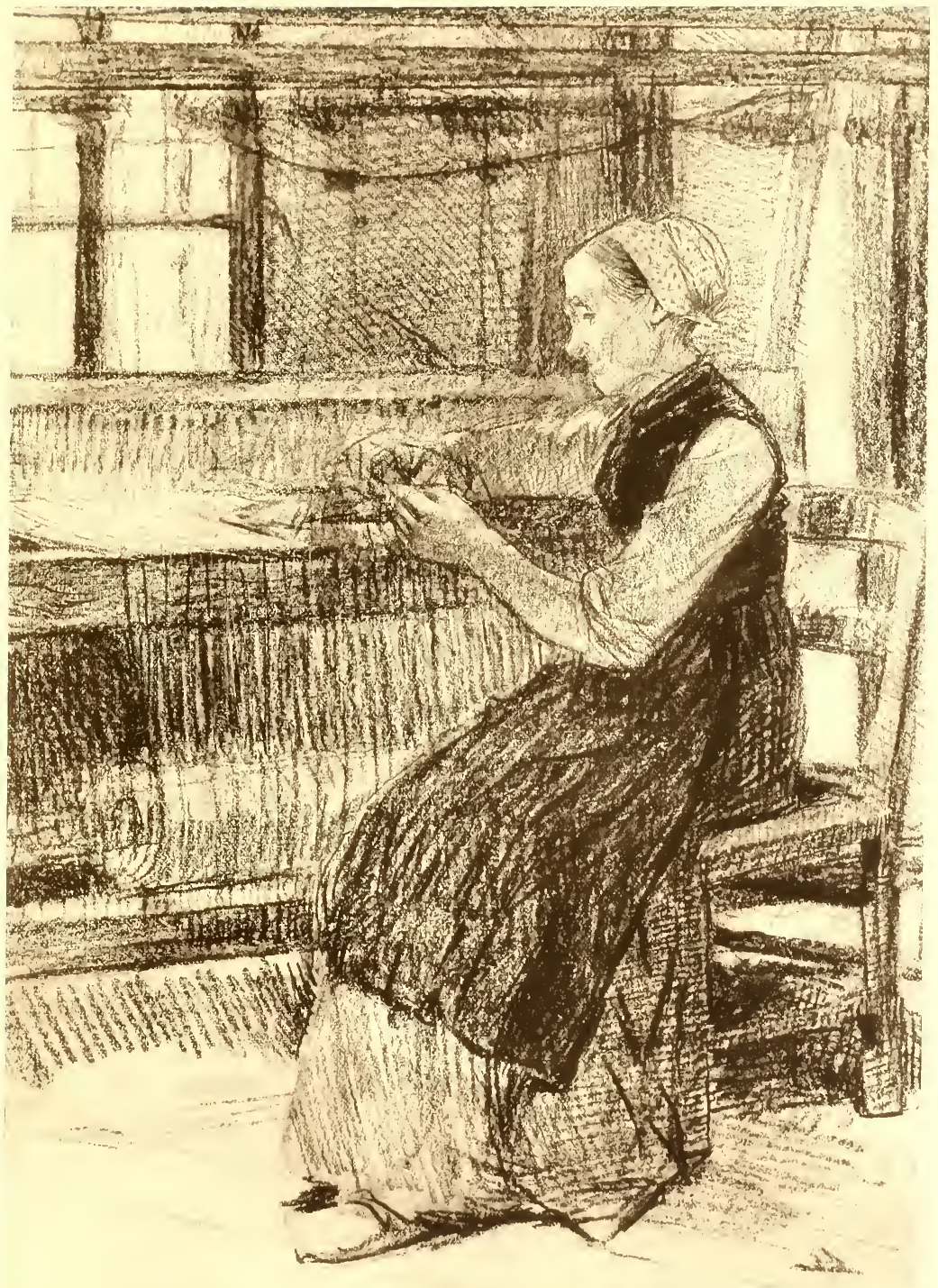

Vv, Cav

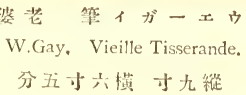


No. 24

\section{WALTER GAY}

AMERICAN

1856-1919

VIEILLE TISSERANDE

(harcoal I)rawing

Height, 11 inches; width, 71, inches

A MIDDLE-AGED woman in a cap and a long apron sits facing the left before a window of an humble building, carefully sorting threads at the large loom where her daily task of weaving is done. Her features are strong. and her expression is patient and one of quiet content.

signed at the lower left, W. Gay. 
No. 25

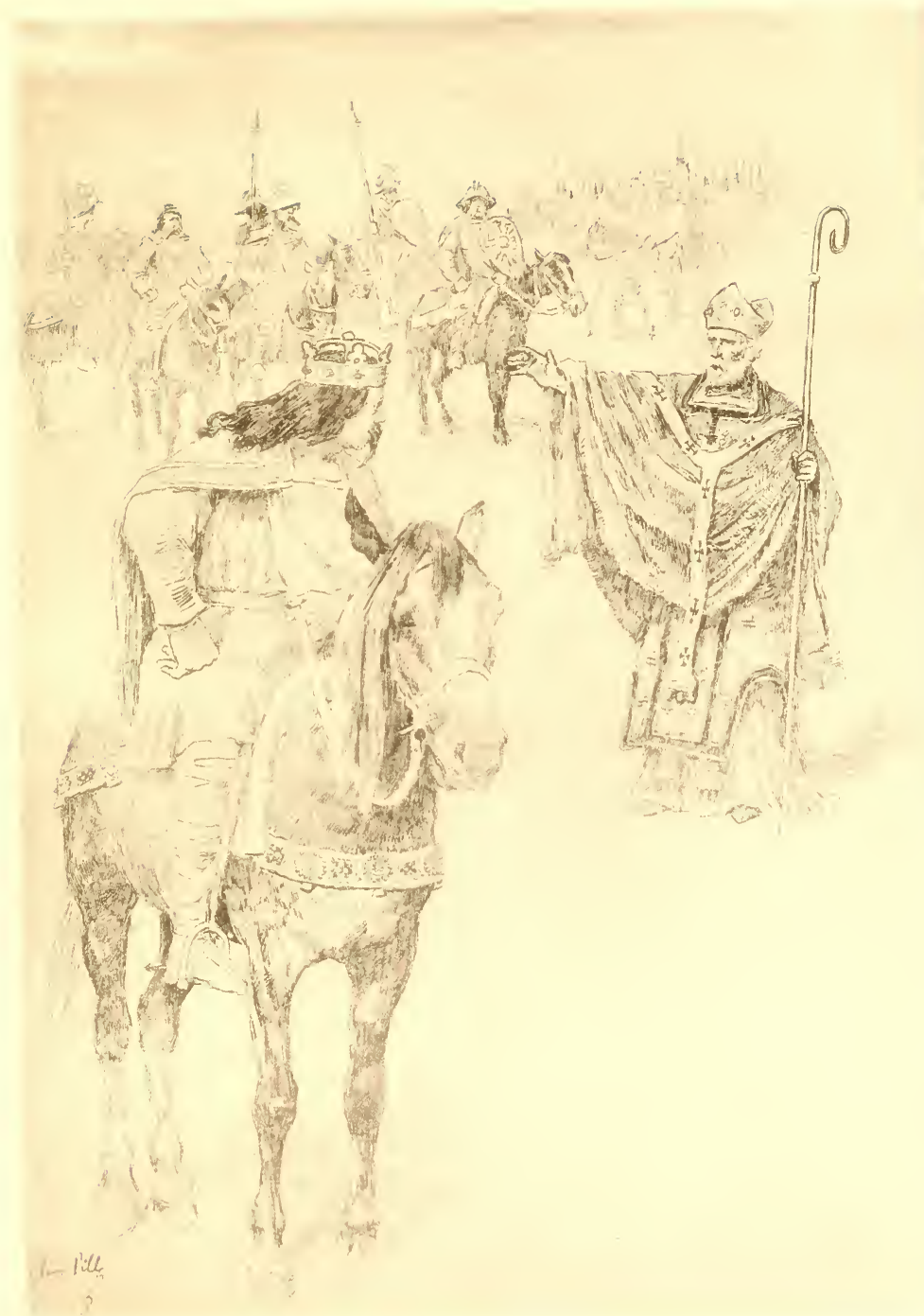

王國ンケンタフ筆ルピーリンタ

Henri Pille. Roi des Francs (dessin de piume).

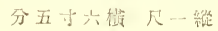


No. 25

\section{CHARLES HENRI PILLE}

FRENCH

Deceased

ROI DES FRANCS

Pen Drawing

Height, 111/2 inches; width, $71 / 2$ inches

THE king, crowned, riding a little in advance of his warriors, has halted his horse and turned to listen to the admonishment of a bishop. (Probably an historical incident or an illustration.)

Signed at the lower left, Henri Pille. 


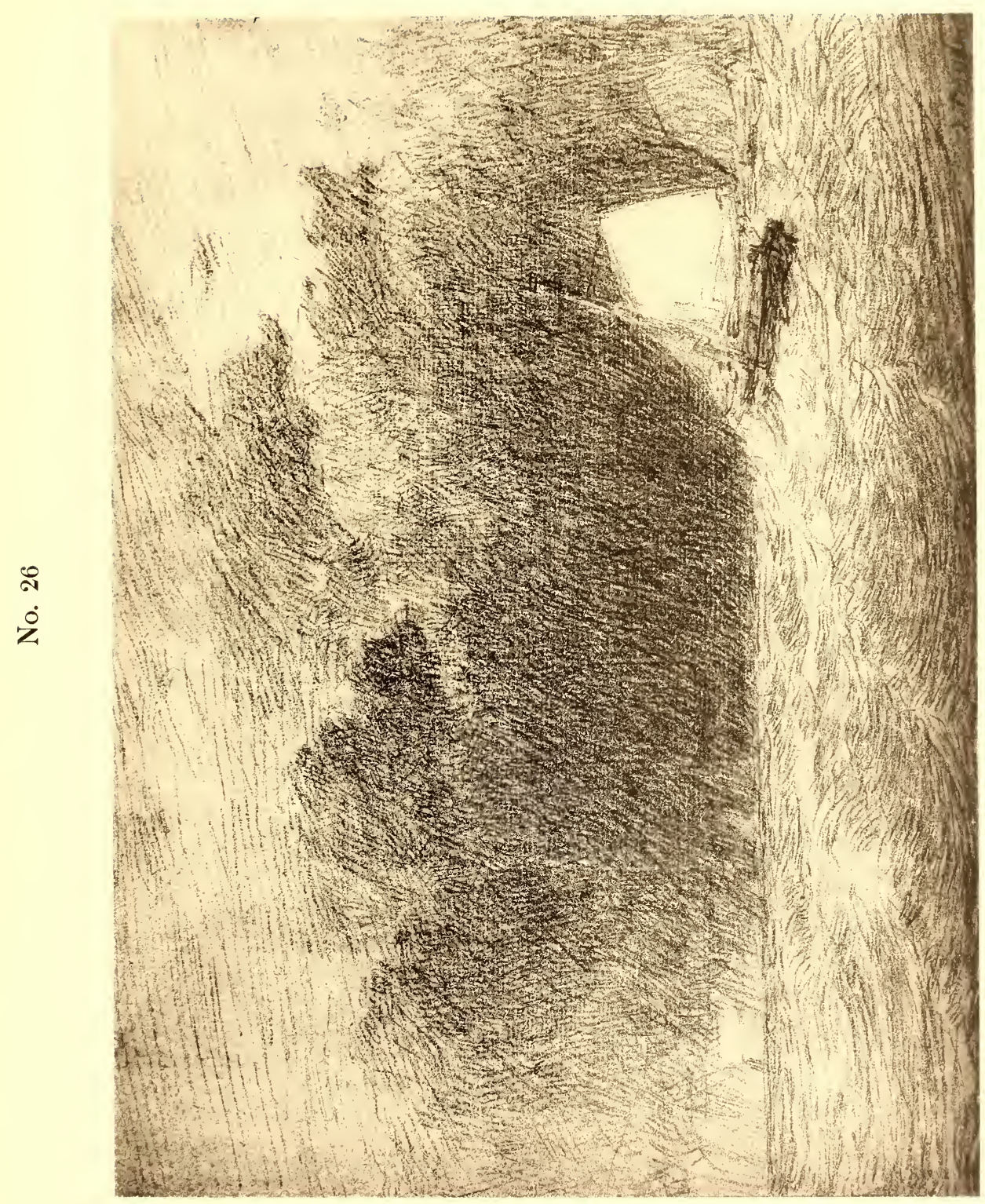

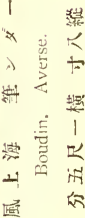




\begin{abstract}
No. 26
I OUIS EUGENE BOLDIN

FRENCH

1824-1898

AVERSE

Black and White

Height, 91\% inches; length, 121/2 inches

A sLOOP-RIGGEv fishing boat, reefed down for a blow and a shower, is working her way out through rising waves in the face of a black squall which is coming up. Both sky and water are full of action, and the storm cloud is ominous. To the starboard another sailing boat is seen.

Signed at the lower right, E. Boudin. Inscribed on the npper margin: " $\mathrm{Wm}$. Grain-Salon, 1886-E. Boudin"; with "H.C." (hors concours) appended in blue.
\end{abstract}


No. 27

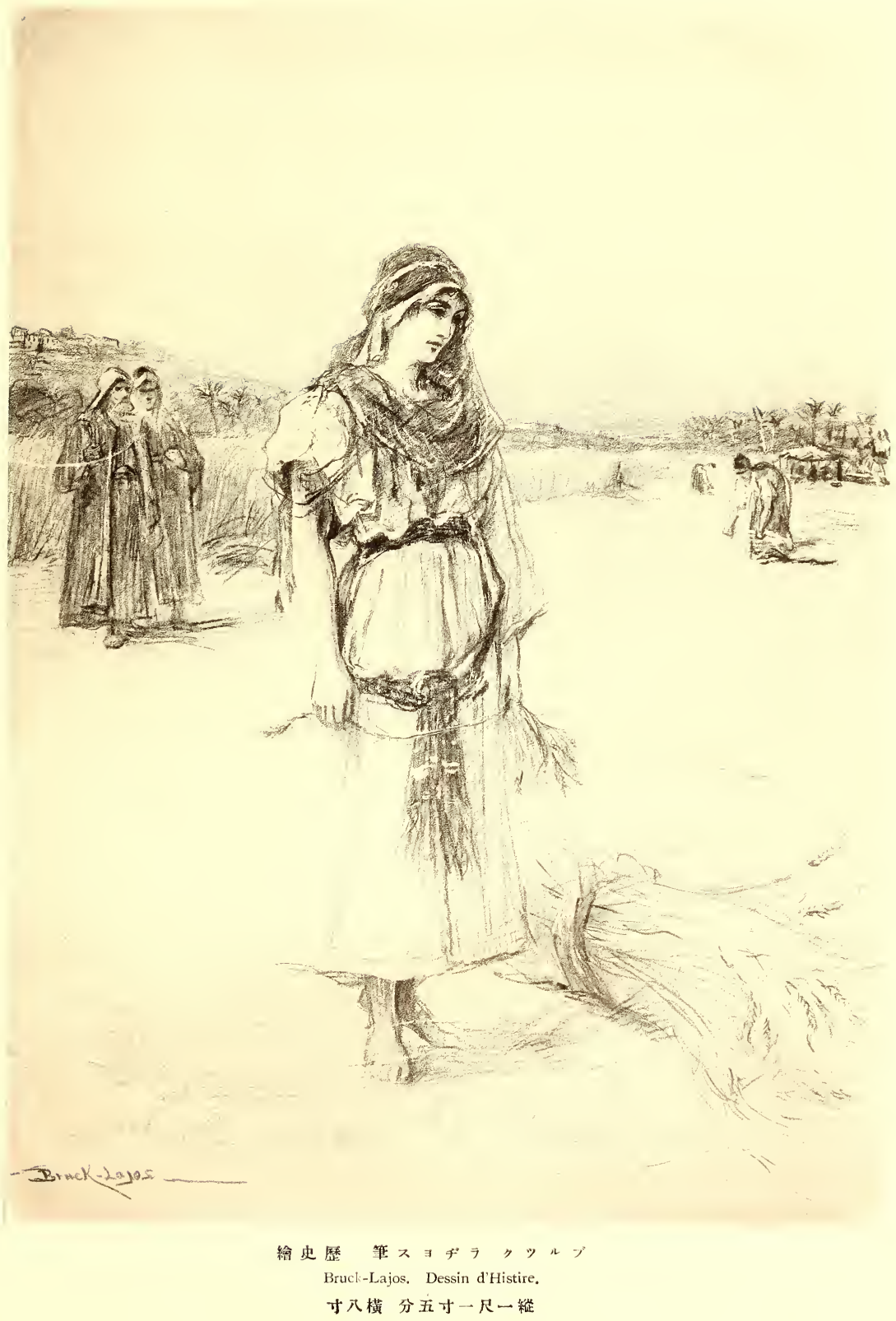


No. $2 \pi$

\section{LOUIS BRUCK-LAJOS}

\section{HUNGARIAN}

$1846-$

\section{DESSIN D'HISTOIRE}

Black and White

Height, 131/. inches; width, 10 inches

A TALL, handsome-featured but pensive young peasant woman, in Hungarian garb, stands barefoot, in her picturesque costume and headdress, in the midst of a partly harvested grain field where other women are reaping and gleaning. In the niddle distance two men in clerical robes regard her from the rear, solemnly. An illustration for a story, or possibly an historical incident. Signed at the lower left, Bruck-Lajos. 


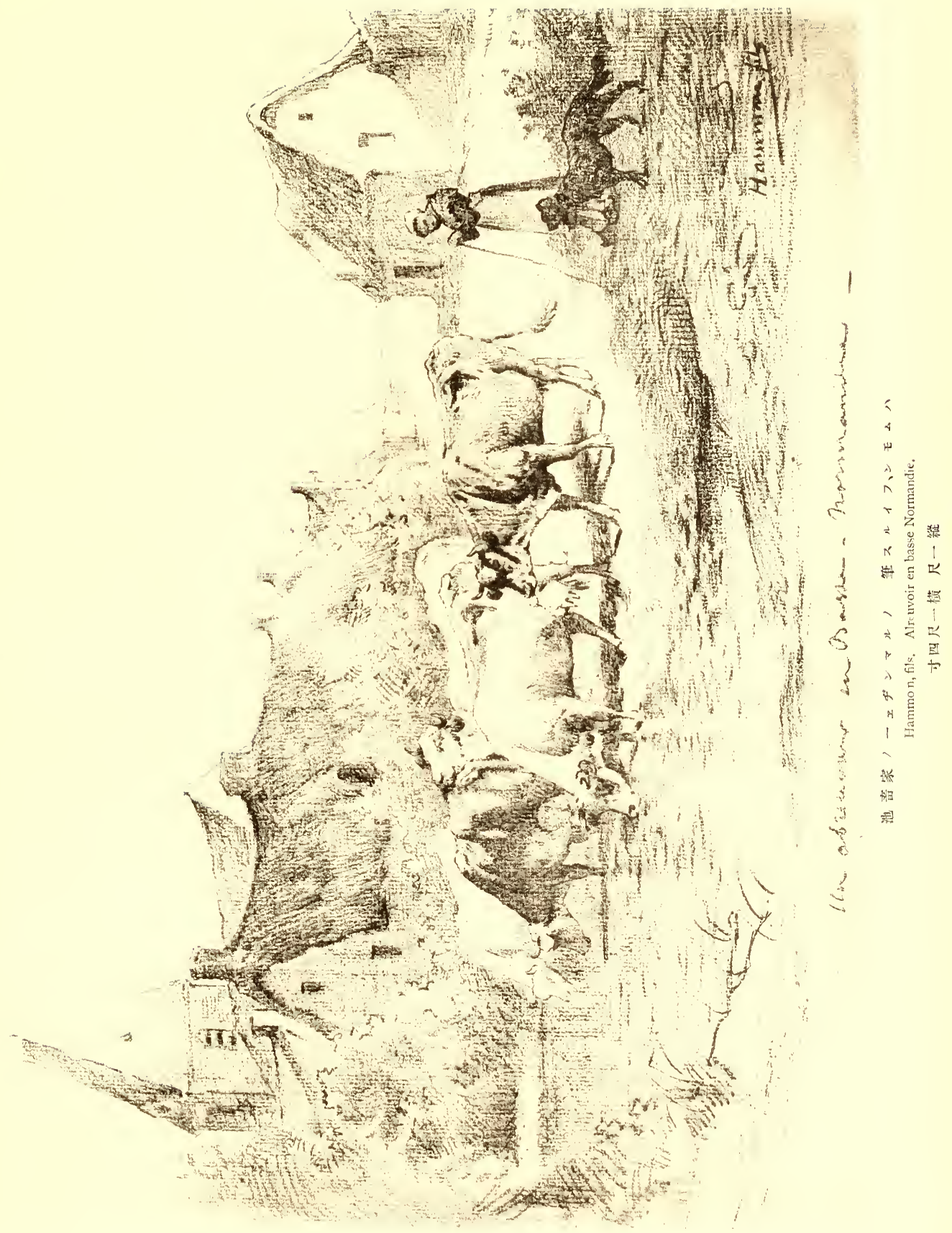


No. 28

\section{HAMMAN, FILS}

BELGIAN

\section{UN ABREUVOIR EN BASSE-NORMANDIE}

Charcoal Drawing

Height, 11 inches; length, 15 inches

THE family herd of five cows has been driven by a peasant woman and a $\operatorname{dog}$ down to drink at a brook, which runs past a group of buildings with irregular roof lines, surrounded by bushes and low trees.

Title inscribed at the bottom.

Signed at the lower right Hamman, fils. 
No. 29

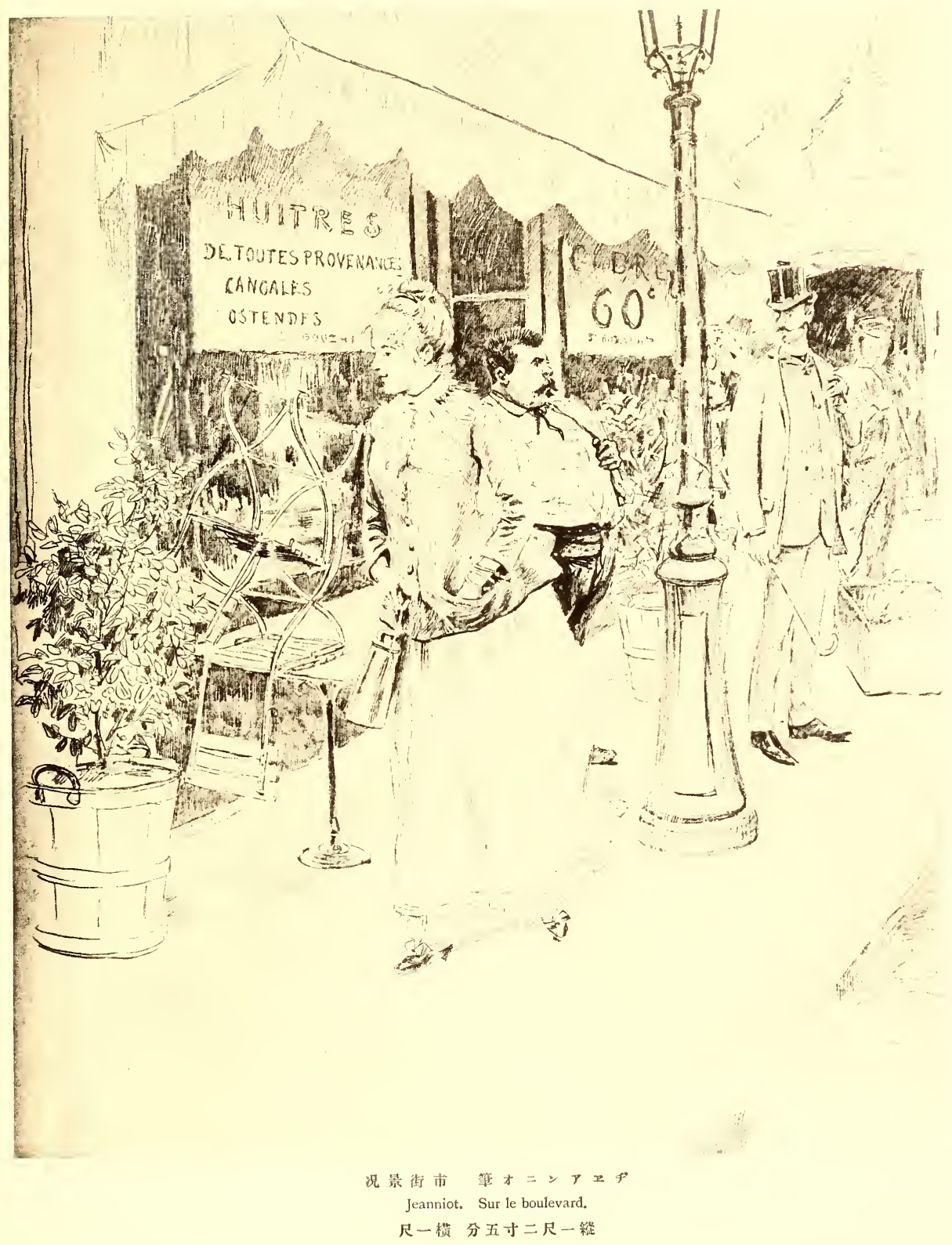


No. 29

\section{PIERRE GEORGES JEANNIO'T FRENCH \\ 1850 -}

\section{SUR LE BOULEVARD}

\section{Drawing}

Height, 15 inches; width, 12 inches

THe terrasse of a small French cider café is shown in the early morning, with the chairs still overturned on the tables. The fat proprietor and casual passers are seen in front, one of the pedestrians being a silk-hatted man with a monocle who has turned to regard a little bonne on her way to do the marketing.

A drawing in black and white for an illustration, probably in color.

Signed at the lower left, Jeanniot. 


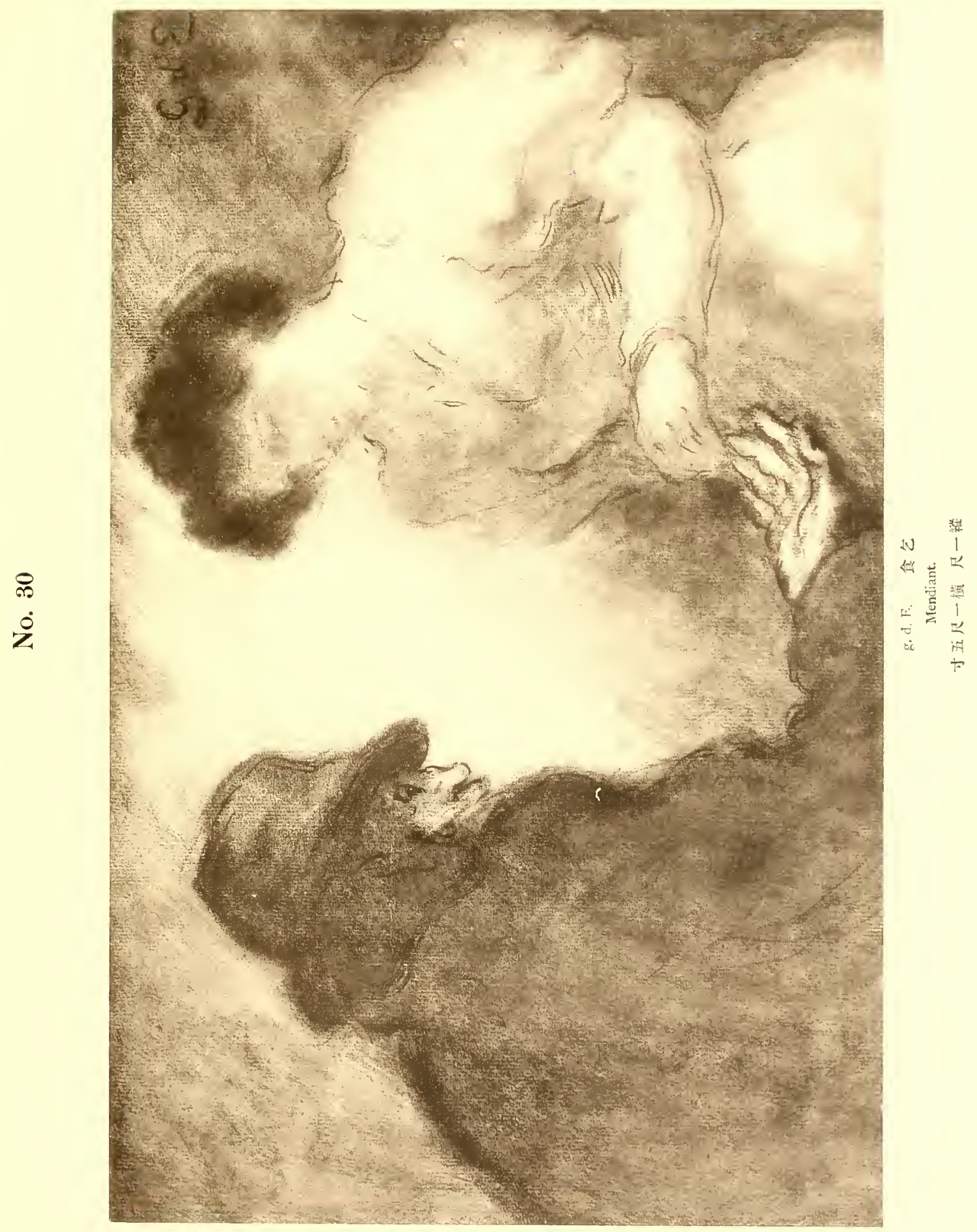


No. 30

G. d'E.

GEORGES D'ESPAGNAT?

FRENCH

MENDIANT

Black and White

Height, 111/2 inches; length, 173/4 inches

Ax aged man with Jewish cast of features, his hat slouched down over his eagerly staring eyes, who stands at the left, extends his open palm to a hatless, buxom young woman who is giving him alms. Both figures are seen at half length.

Signed at the upper right, G. d'E. 
No. 31

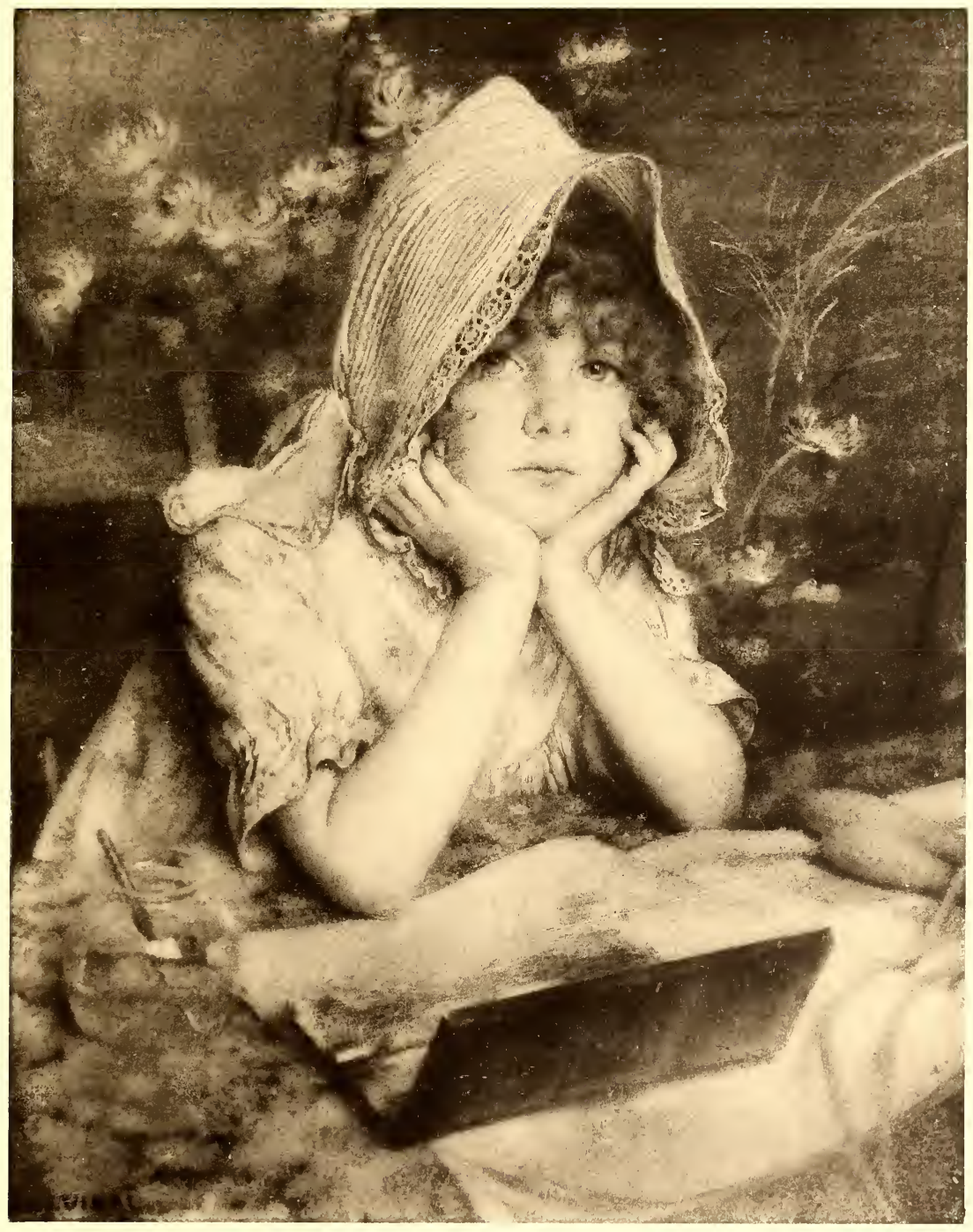

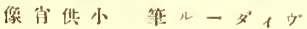

Vidal. Jenne fille.

寸三尺一横 寸九尺一縫 
No. 31

EUGENE VIDAL

FRENCH

Nineteenth Century

"A RAINY DAY"

Crayon

Height, 221/2 inches; width, 151/2 inches

A LiTTLE girl, with large round eyes, in a large bonnet and short-sleeved frock, leans on her elbows and rests her chin on her hands, as she sits behind a table and facing the spectator, and seems to be sorry that she cannot go out of doors.

Signed at the lower left, Eug. Vidal.

Exhibited at the Royal Academy. 
No. 32

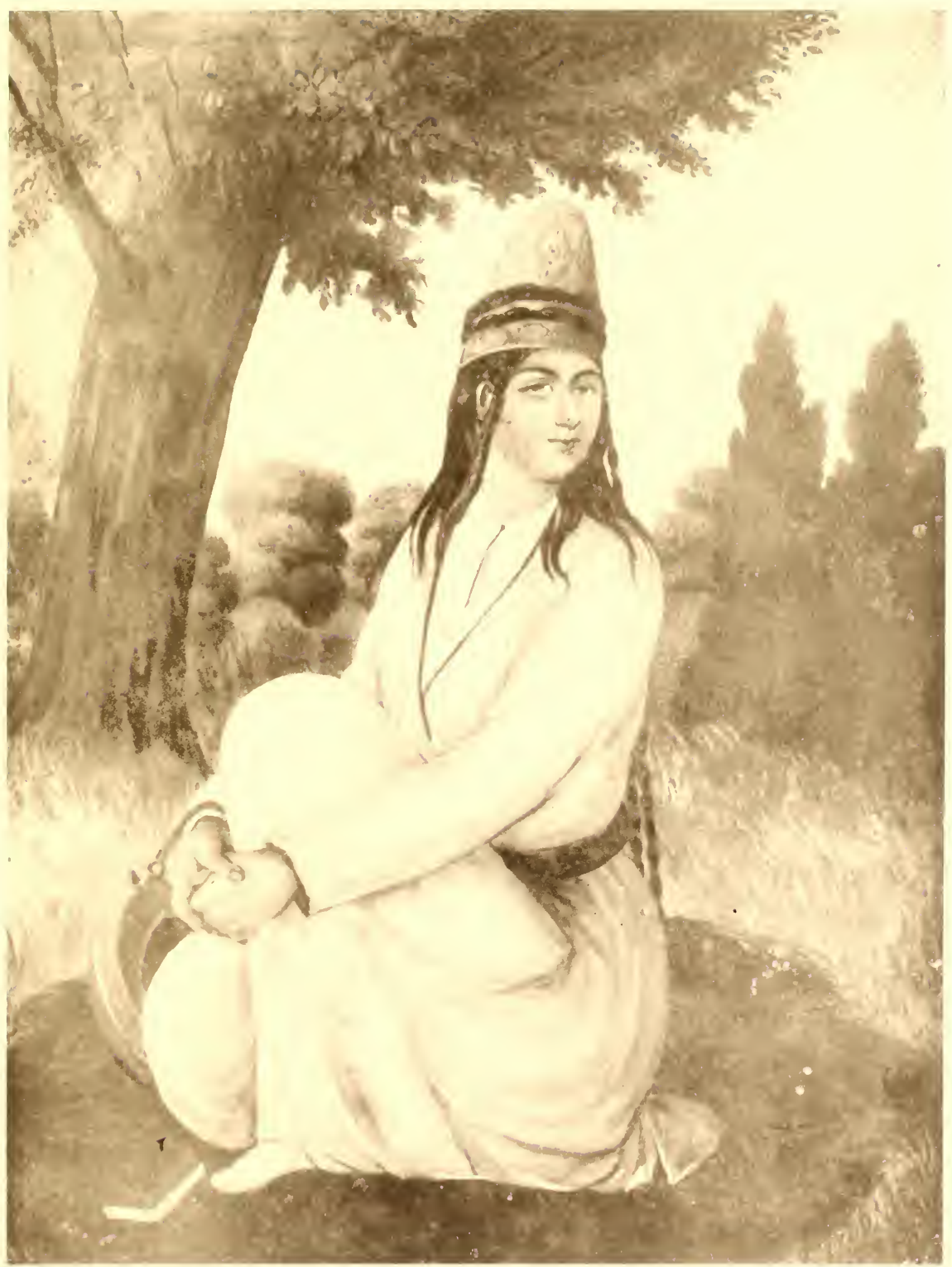

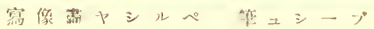

Elache. Cofie d'arrès une miniature jersamne.

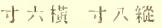


No, 32

PHILIPPE CHARIES BI.ACHE

FRENCH

Deceased

COPIE D'APRES UNE MINIATURE PERSANNE

\author{
Water ('olor \\ Height, 81.2 inches; width, $61_{2}^{2}$ inches
}

THis copy of a Persian miniature painting presents a young person seated on a hair rug, on the grass at the base of a tree. One knee is bent under, the other flexed against the breast. The face is thoughtful, as of a dreamer, and a book lies at hand on the rug. The miniature has been copied even to the intricacies of the framing, which at the top inchudes three ornamental medallions. 


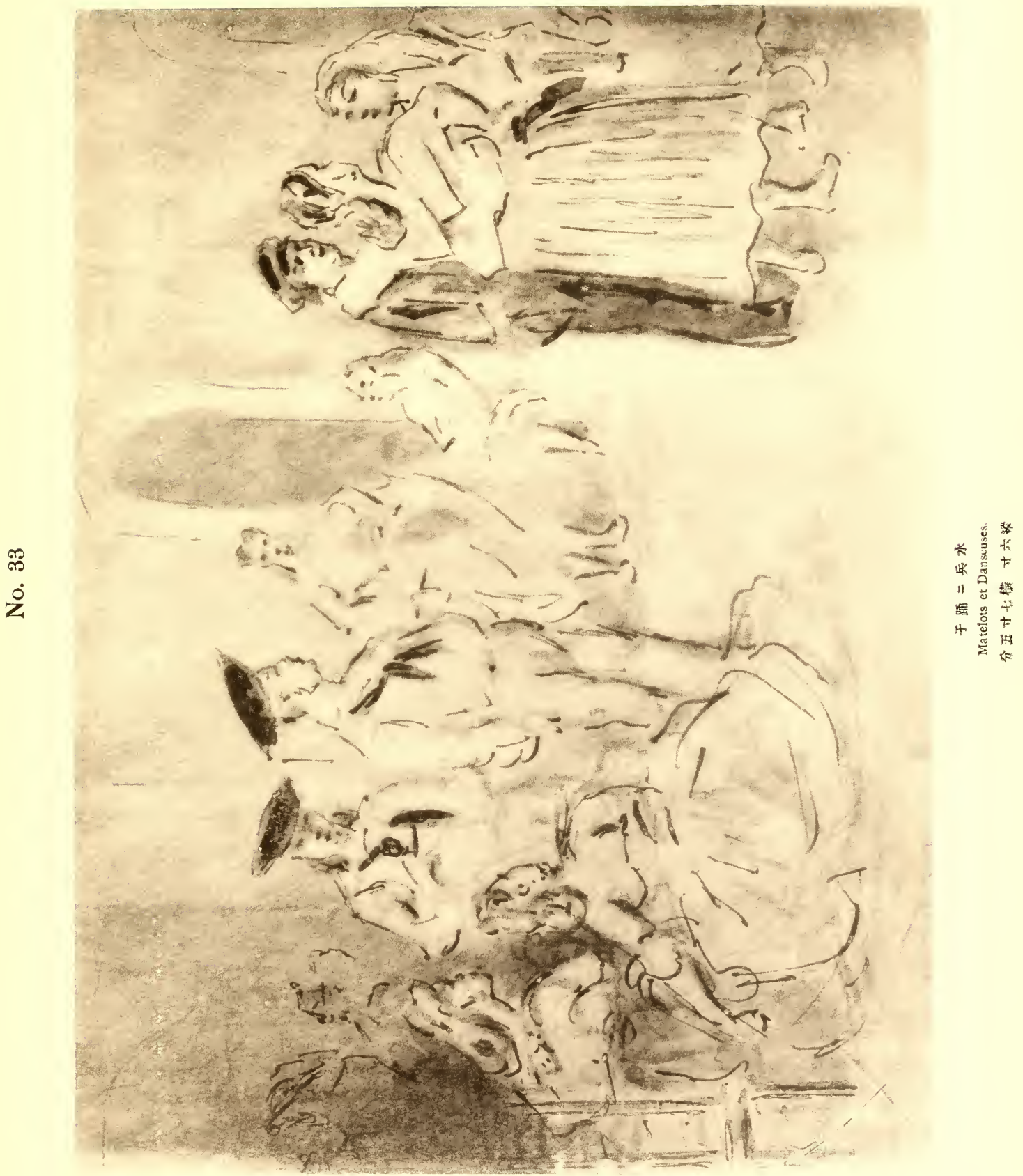


No. 33

\section{UNKNOWN}

\section{MATELOTS ET DANSEUSES}

\section{Water Color}

Height, 61ㅡㄹ inches; length, 9 inches

A FREE sketch of several sailors amongst a group of female dancers, some of the dancers appearing in Oriental costume. 


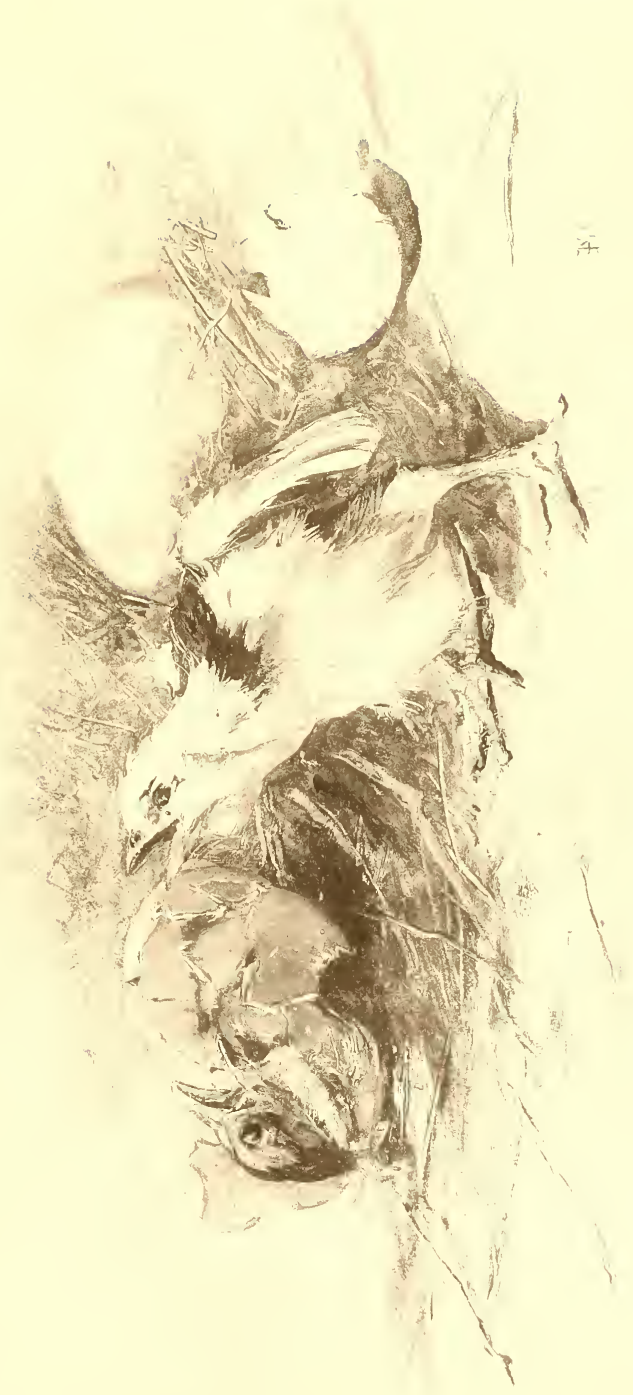

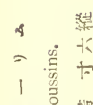

$$
\begin{aligned}
& \text { सै क 此 } \\
& \text { 交市 }
\end{aligned}
$$

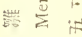

$$
\begin{aligned}
& \text { 什 尔 }
\end{aligned}
$$


No. 34

\section{ALFRED ÉMILE MËRY FRENCH \\ $1824-$}

POUSSINS

Water Color and Pastel

Height, $71 / 2$ inches; length, 10 inches

Two AwKWARD chicks that have just burst from their shells, making their first noise in the world. Back of and about them, suggestions of the parental nest.

Signed at the lower right, Mery. 


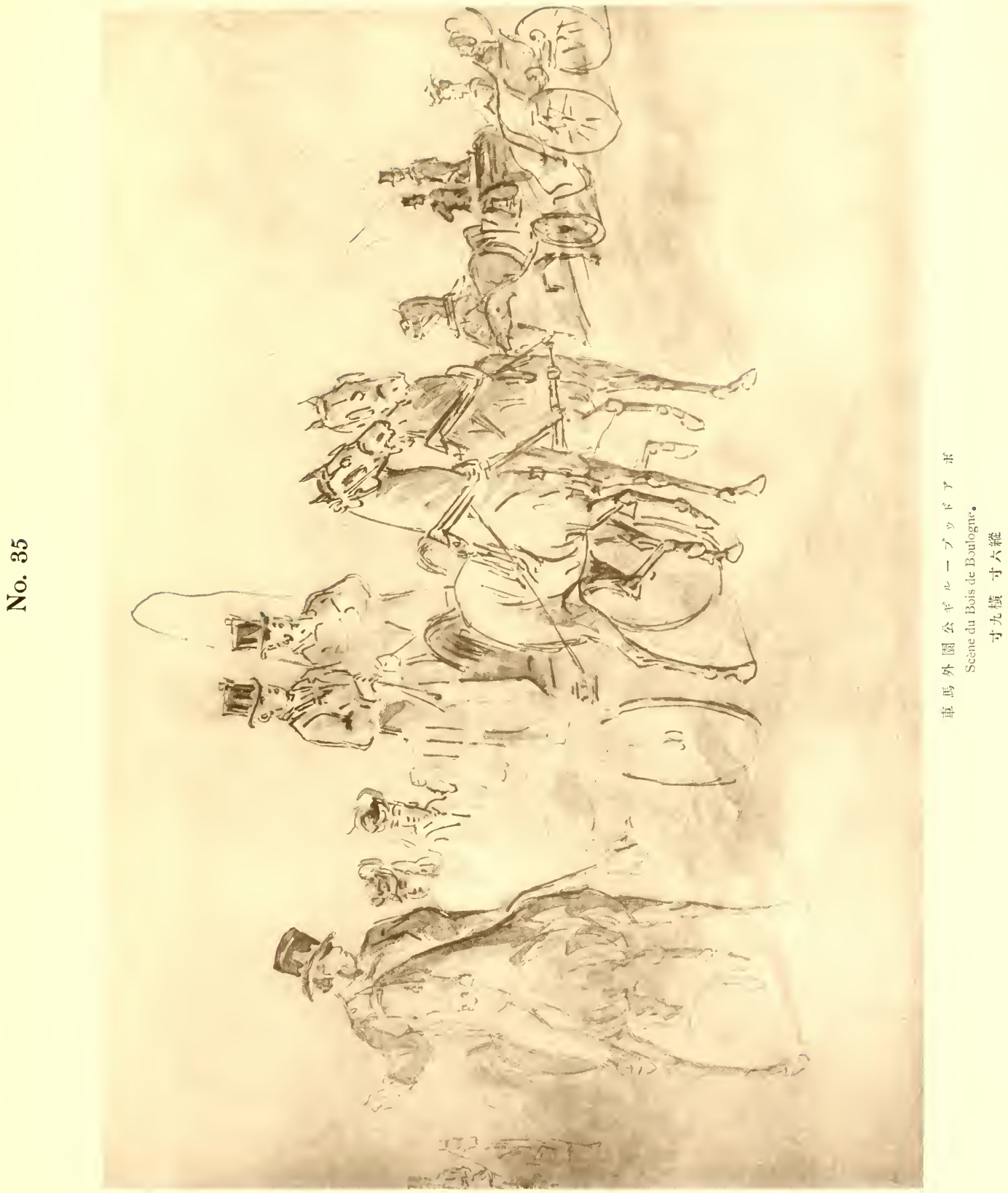


No. 35

\section{UNKNOWN}

\section{SCIENE AU BOIS DE BOULOGNE}

\section{Water Color}

Height, $71 \frac{1}{2}$ inches; length, 11 inches

A sketch of some visitors to the Bois de Boulogne in the days before automobiles, when it was fashionable to drive there with coachmen and horses, and to ride in the park as well. 
No. 36

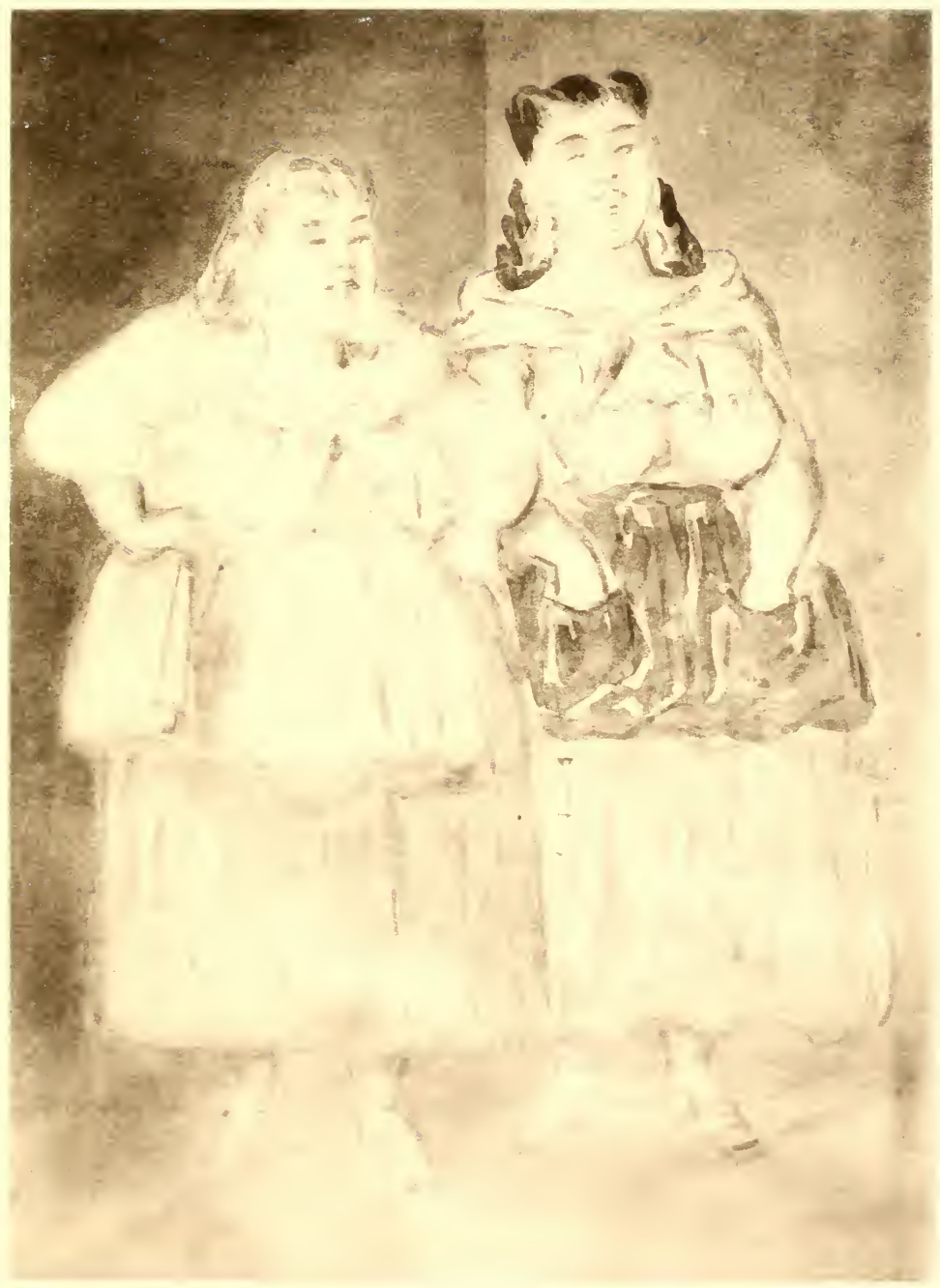

女听二

Deux, Cantatrices.

分五市六横 寸九緶 
No. 36

\section{UNKNOWN}

\section{DEUX CANTATRICES}

Water Color

Height, 103/4 inches; width, 8 inches

A FAT, blond stage singer, arms akimbo and skirts short, and her equally fat brunette sister, in a stage pose side by side, both with pleased expressions of self-content over their own singing. 


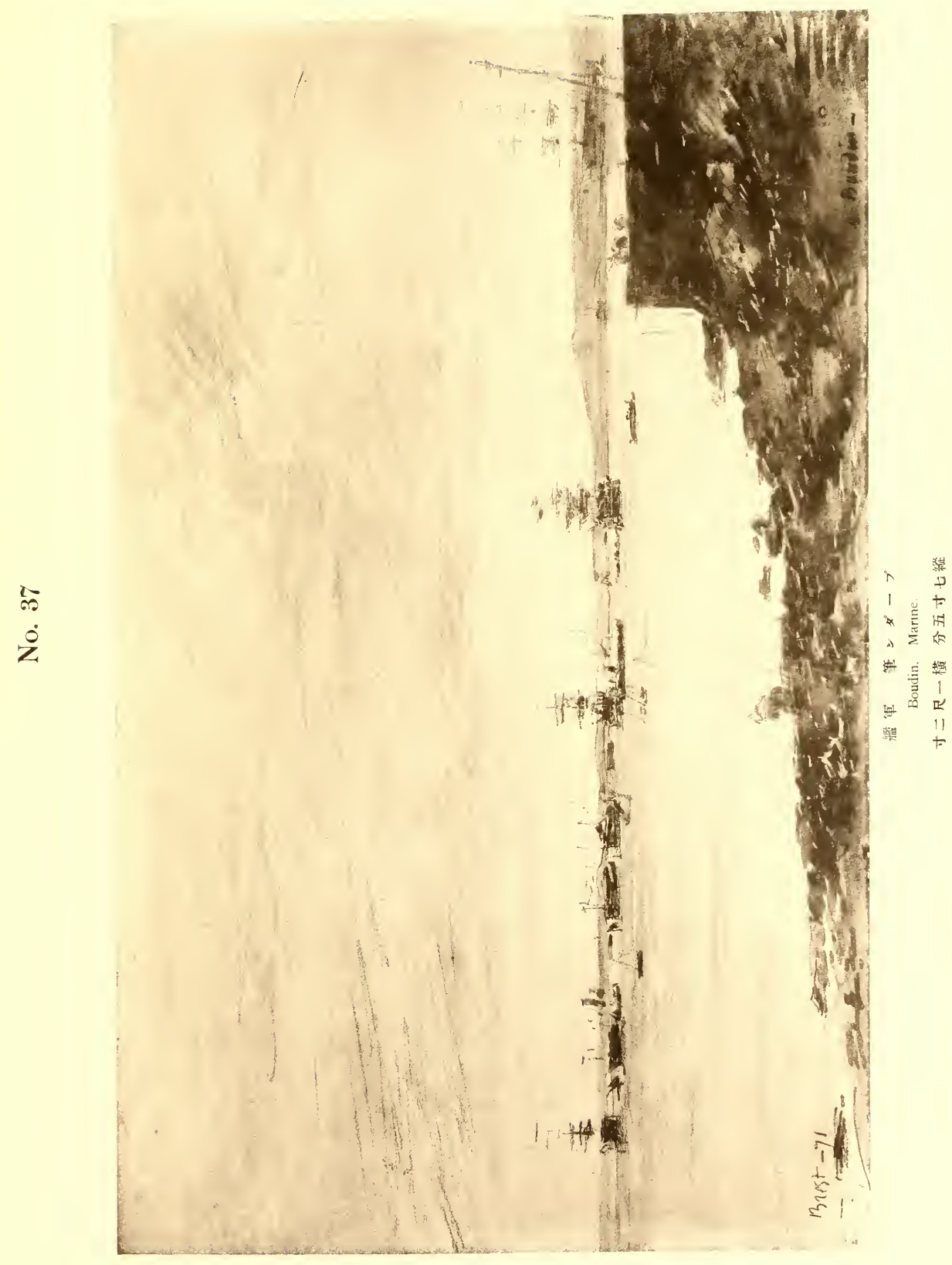


No. 37

\section{LOUIS EUGENE BOUDIN}

FRENCH

1824-1898

MARINE

Water C'olor

Height, 9 inches; length, $14: 3 / 4$ inches

A skEтch of the harbor of Brest, the westernmost port of France, in Finistère, with scattered shipping-square rigged ships and steamers - mainly at their anchorages. It is low tide, and a bit of the beach is visible in the foreground, beneath a bulkhead or quay on which a few figures are to be seen.

Signed at the lower right, E. Boudin.

Inscribed at the lower left, Brest, ${ }^{\prime} 1 ; E . B$. 


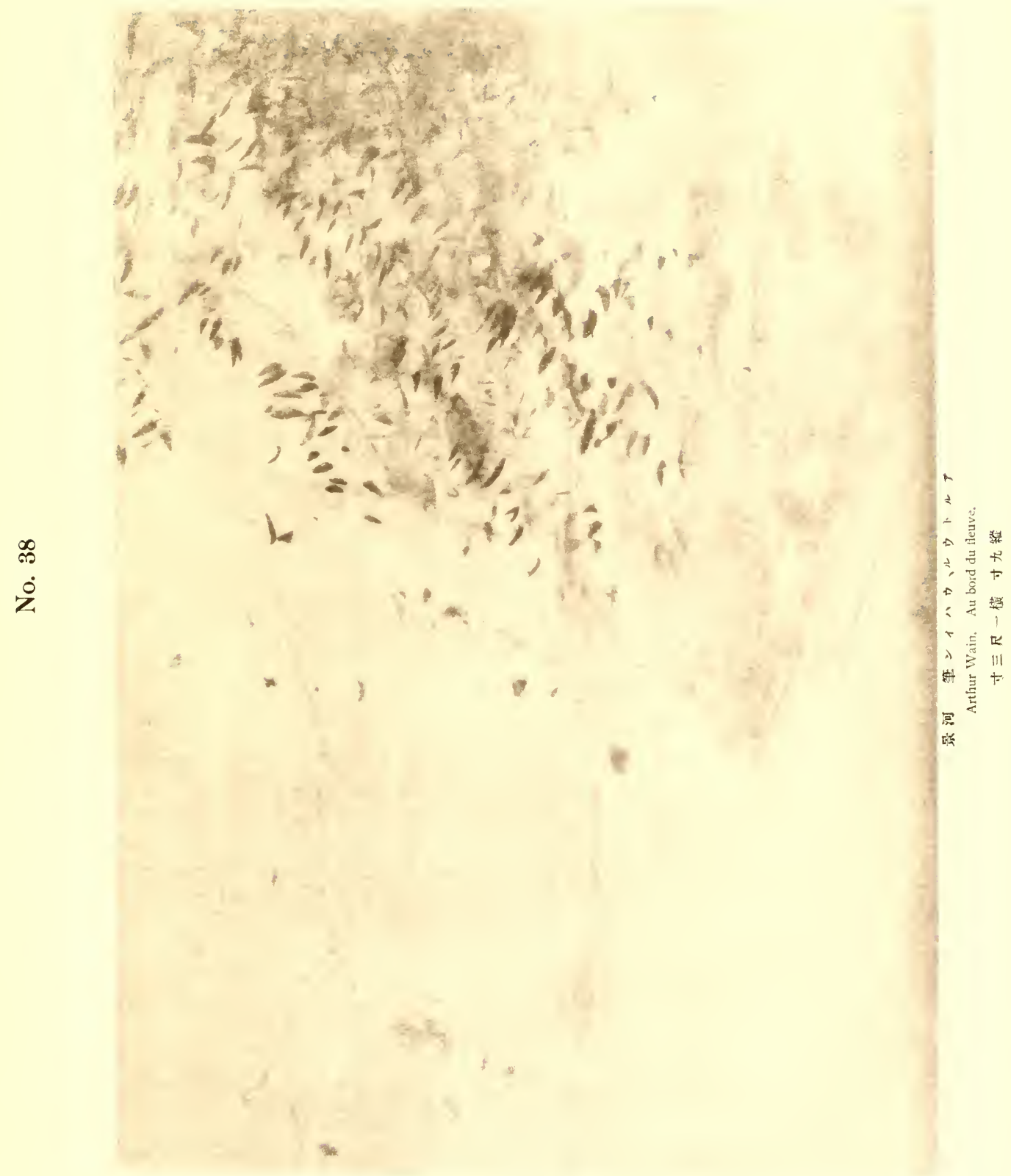


No. 38

\title{
J. ALDEN WEIR
}

AMERICAN

18.52 -

\section{THE BROOK}

\author{
Water Color \\ Height, 10:/4 inches; length, 151/2 inches
}

TuE blue-gray waters of a narrow stream are rounding the bend of a flat, green bank, where a tree with green and some yellow leaves grows. The stream passes from sight at the foot of a round-topped hill.

Signed at the lower right, J. Alden Ireir.

Exhibited as "The Brook" at the Fourth Anuual Exhibition of the New York Wrater Color Club (1893). The title "Au bord du fleuce" was acquired later. 
No. 39

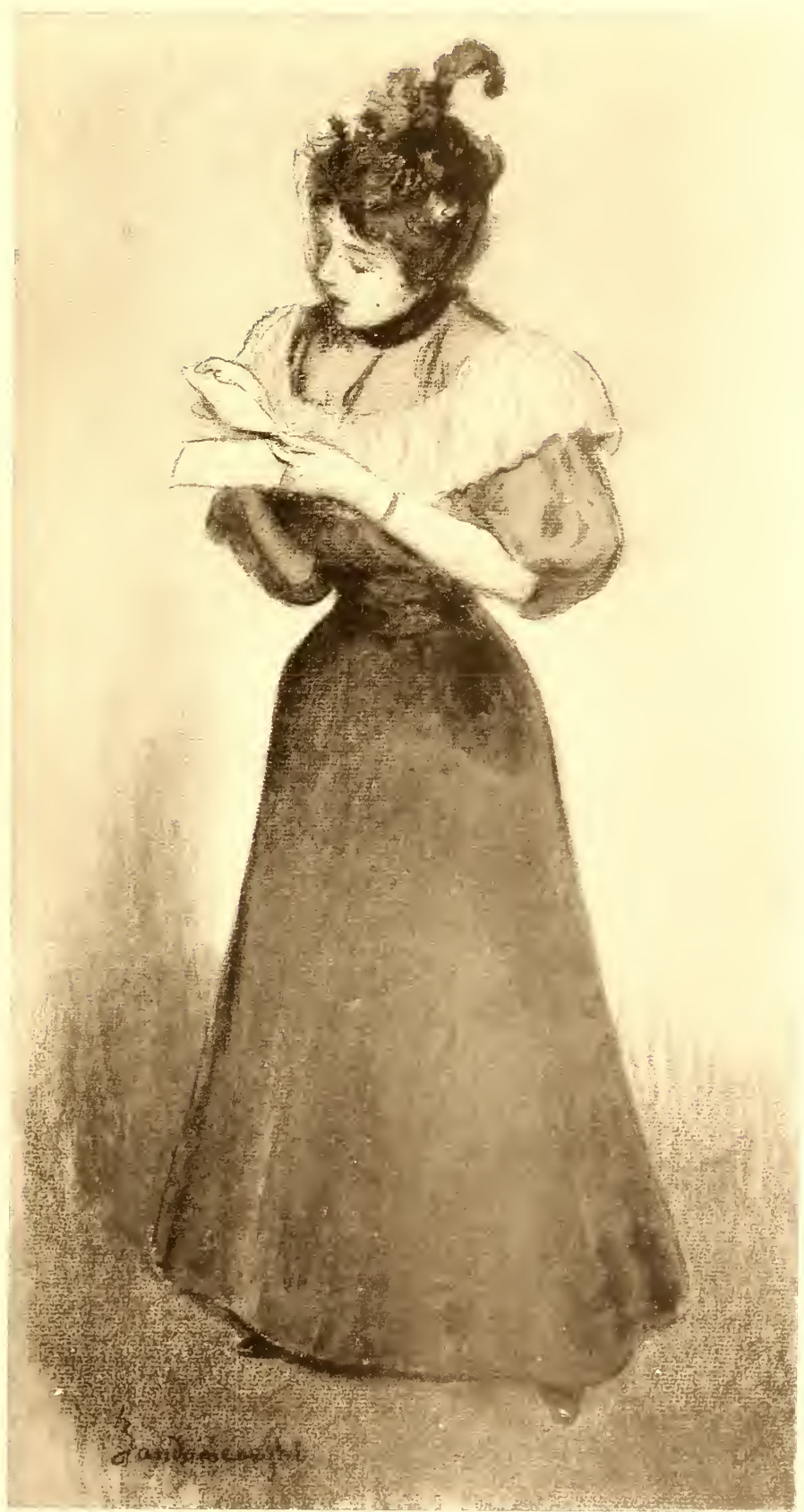

見交人畦筆グッネメドンアッ゙

Zandom neghi. Dame lisant une lettre,

寸七横分五寸三尺一樅 
No. 39

\section{FEDERICO ZANDOMENEGHI}

ITALIAN

1841 -

\section{DAME LISANT UNE LETTRE}

Water Color

Height, 16 inches; width, 81\% inches

A YelLow-HAired young woman, très chic, in street costume, has paused to read a missive. She wears a light green waist, a deep blue skirt, and a small, flowerbedecked bonnet, and stands with feet wide apart as she peruses the writing attentively.

Signed at the lower left, Zandomeneghi. 


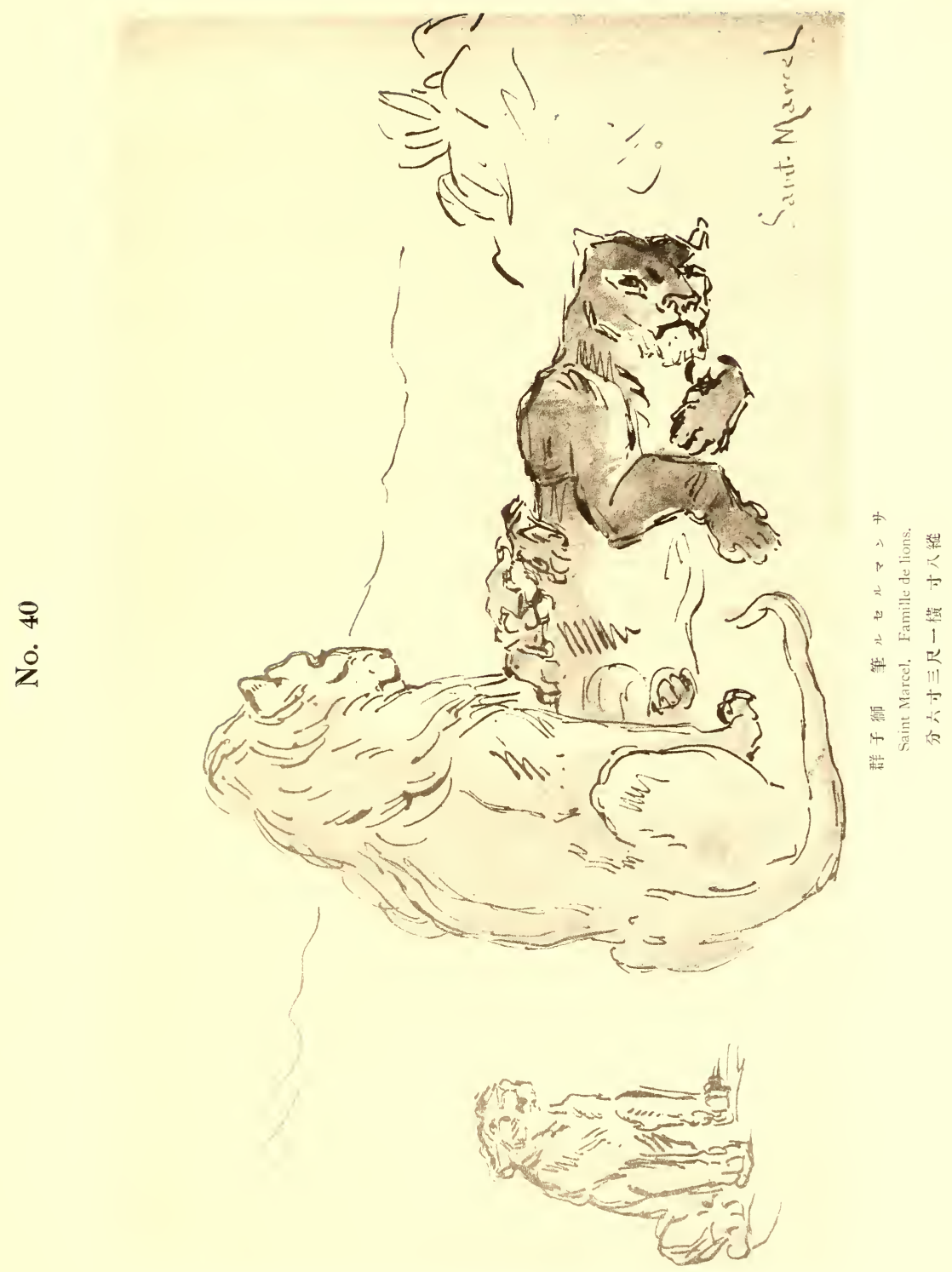


No. 40

CHARLES EDMONDE SAIN'T-MARCEL,

\section{FRENCH}

$-1890$

\section{FAMIILEL DE LIONS}

$$
\text { Water color }
$$

Height, 91\% inches; length, 16 inches

A simple drawing, with much expression, of four members of the leonine tribe at rest on the slope of a hill, all done in black and the tawny hue of the beasts' coats. A lion with a massive head is seated on his haunches, back to the spectator, his head turned to look down at a lioness who lies on her side facing the spectator, and at a cub which peers over her back. Another cub sits awkwardly at the left, looking up hopefully at its father.

Signed at the lower right, Saint-Larcel. 
No. 41

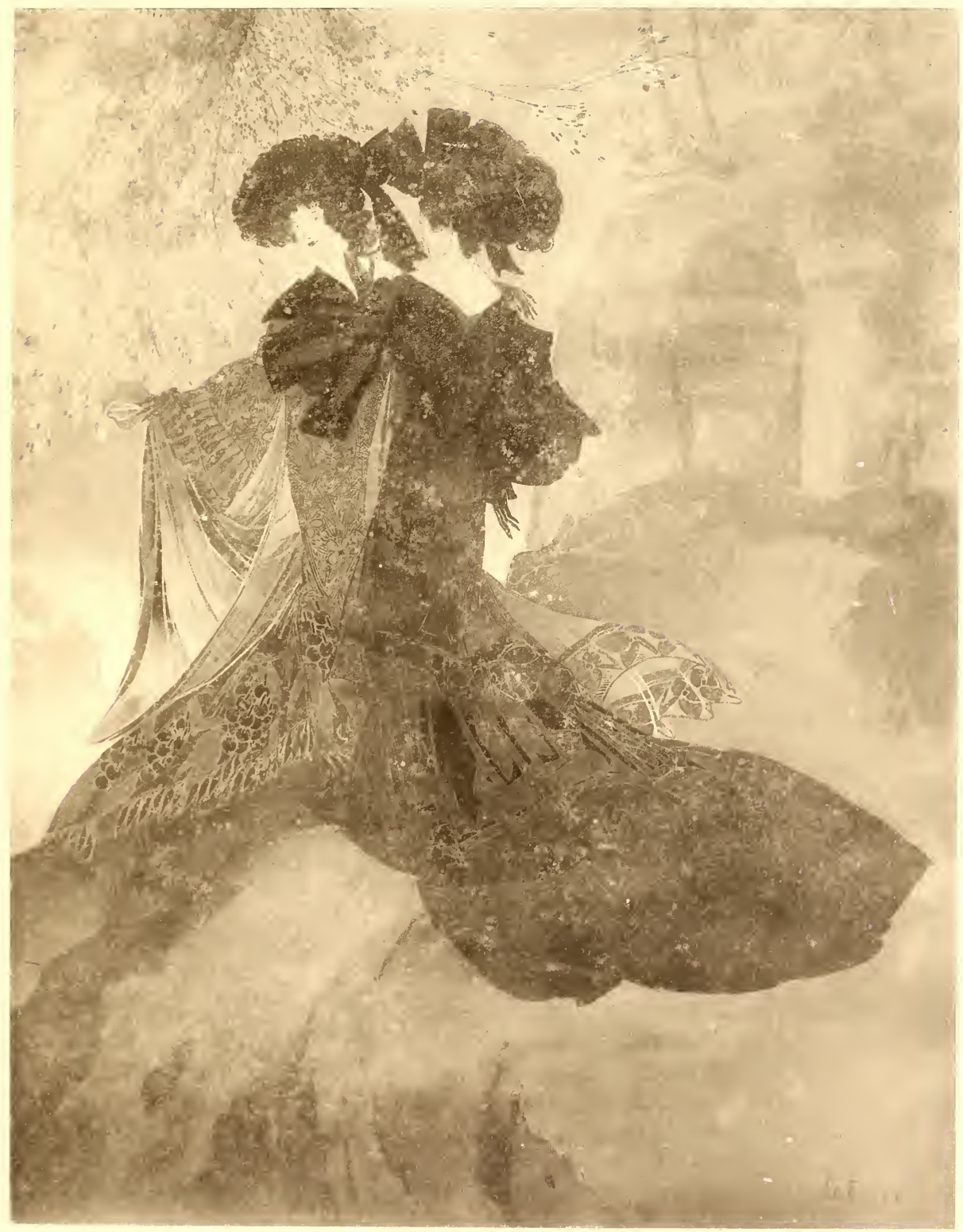

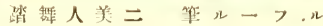

Le feure. Fames.

寸二尺一横 寸六尺一縱 


\section{No. 41 \\ GEORGES DE FEURE \\ FRENCH \\ Contemporary}

DAMES

Water Color

Height, 19 inches; width, 141/2 inches

A curious painting, of Japanesque effect, yet Occidental. Two European women in European garb are so arranged with their draperies as to suggest the flowing robes and poses of Japan. They stand perched upon a mound or terrace before a huge stone gateway, flowery branches of unseen trees overhanging their heads. The landscape falls away beyond them in Japanese picturesquerie, dotted there with wave lines, a building or a tree. One woman is seen in back and profile, the other faces front, half-turned to the left.

Signed at the lower right, de Feure. 
No. 42

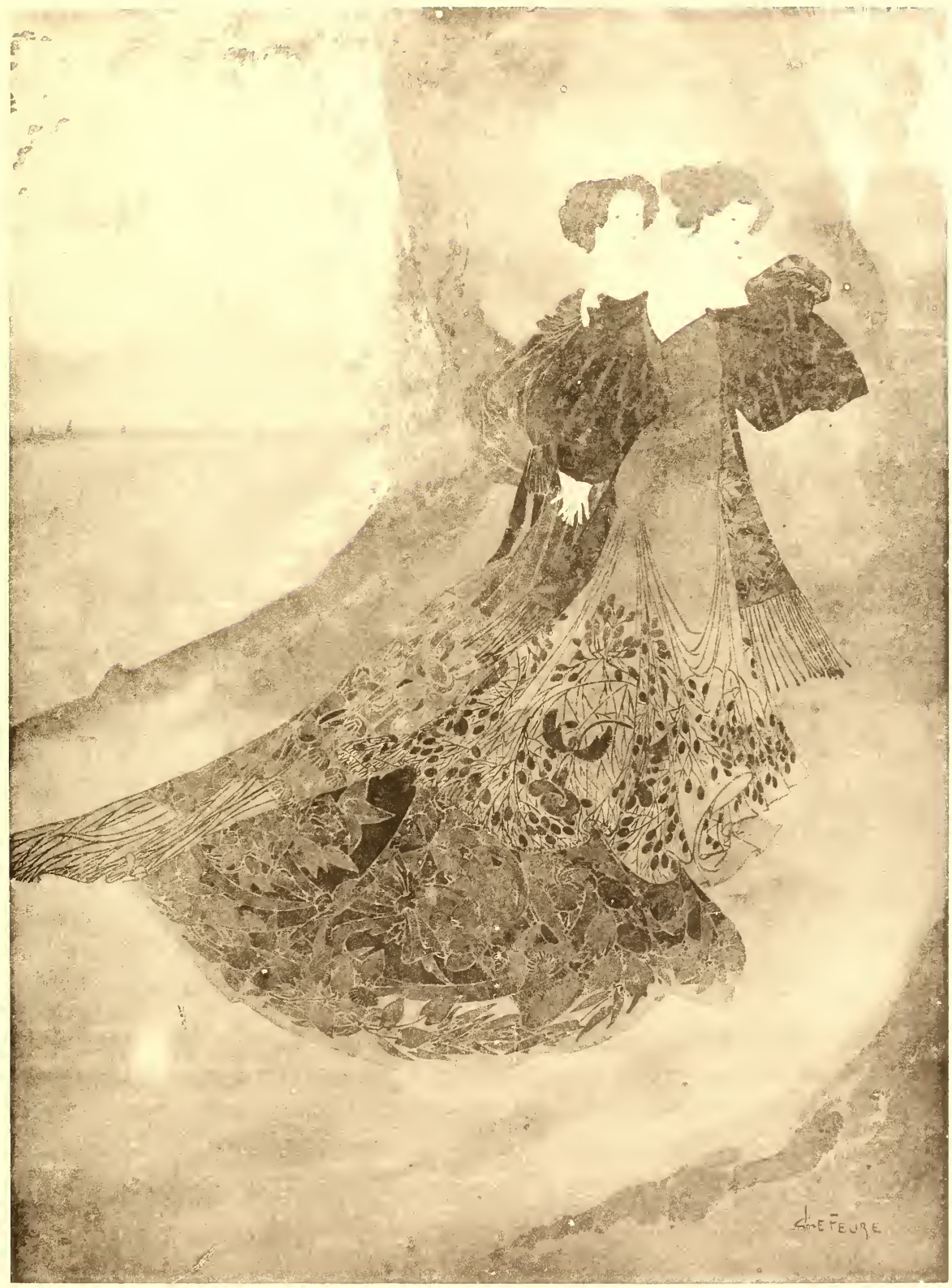

行步人美二下樹筆几ーフ、n

Le Feure, Dames,

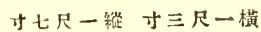


No. 42

\section{GEORGES DE FEURE}

\section{FRENCH}

Contemporary

DAMES

Water Color

Height, 201/2 inches; width, 15 inches

Two tall women, a blond and a brunette, in low-necked gowns with sweeping trains elaborately ornamented in many colors, are walking, each clasping a hand of the other, on the shore of a large body of water upon which many distant sailing boats are seen. The women, walking toward the right, turn their heads so that their faces may be seen as they pass an enormous tree trunk--the whole, though European painting, done with quasiJapanese suggestion, in a brown tone.

Signed at the lower right, de Feure. 
No. 43

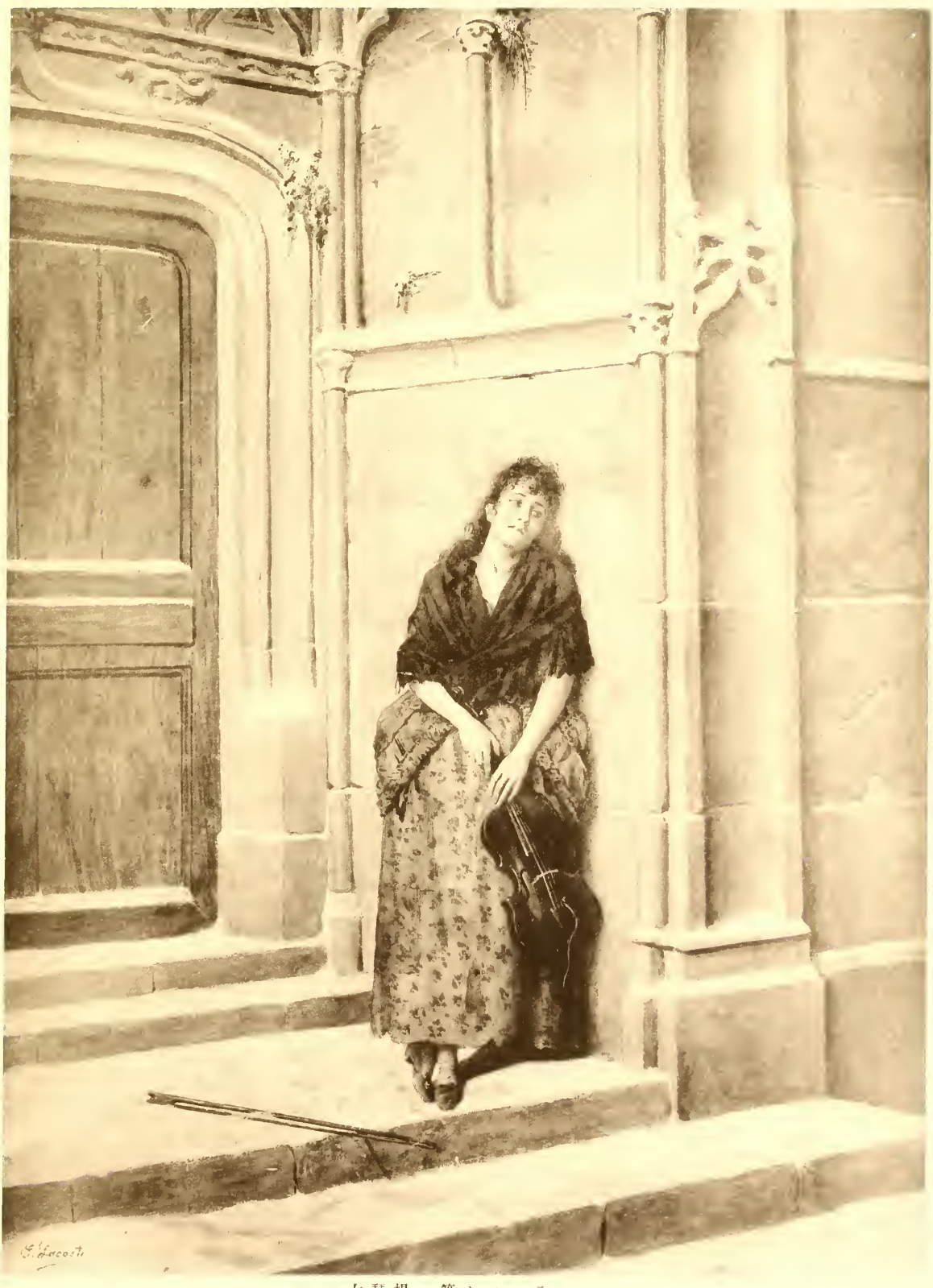

女琴提笔、スコラ

I acoste. Dame jount au Violon.

寸一尺二縱分注才五尺一㮛 
No. 43

PIERRE EUGENE LACOS'TE

FRENCH

1818 -

FEM HE JOUANT DU TIOLON

Water ('olor

Height, 25 inches; width, 181/2 inches

'THE woman, a street musician, a'weary,--a string of her violin broken,--has mounted the steps before a closed church door and leans disconsolately against the porch, her bow lying in the dust at her feet. She is of Southern European type and wears a black shawl, green waist, and a wide, full and ornamental pink skirt, with old blue stockings.

Signed at the lower left, P. Lacoste. 
No. 44

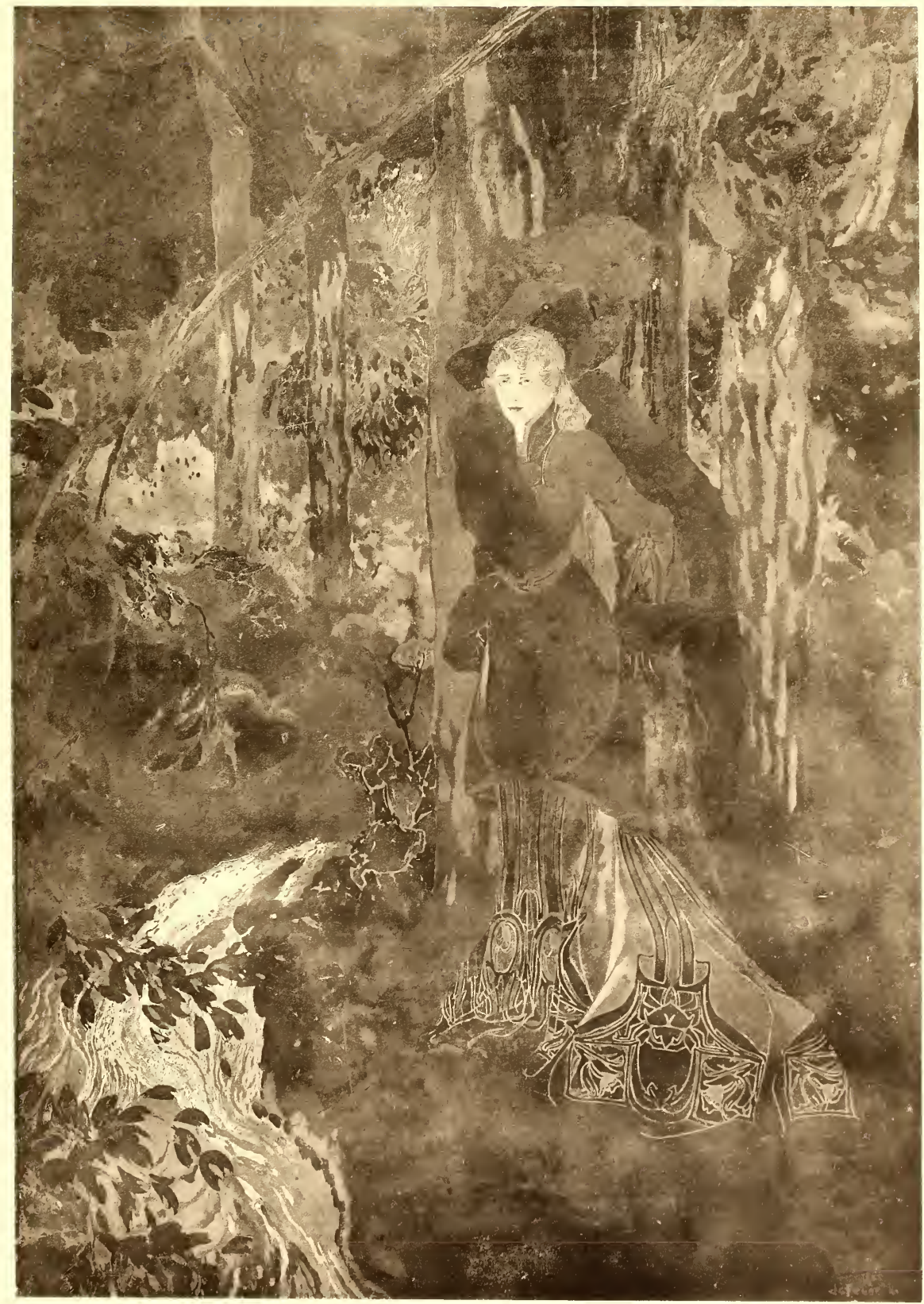

人美, 服赤二秝簕ルーフル

Le Feure, Dame rouge au bois.

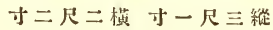


No. 44

GEORGES DE FEURE

FRENCH

Contemporary

DAME ROUGE AU BOIS

Water Color

Height, $3{ }^{1} 1 \% 2$ inches; width, 26 inches

The interior of a wood, characteristically painted by this artist in fantastic coloring-trees red and blue and green before the light of a red sky - a Japanesque sparkling waterfall in the foreground. In the center of the decorative composition a tall woman, all in red, stands, like a weird presence from another world-though in modern costume-looking out into space.

Signed at the lower right, de Feure. 
No. 45

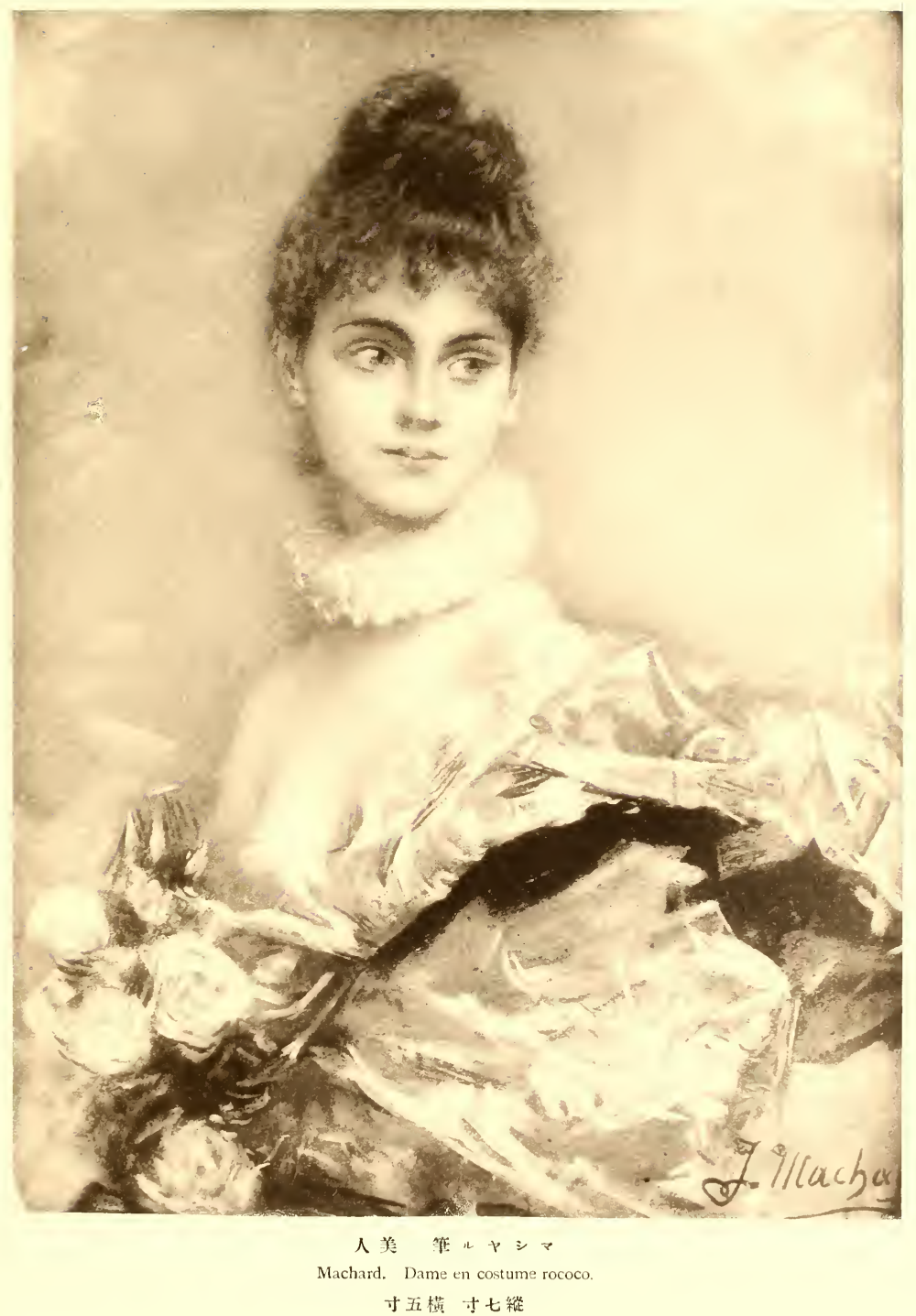


No. 4.5

\section{JULES LOUIS MACHARD}

\section{FRENCH}

1839-

\section{DAME EN COSTUME ROCOCO}

$$
\text { Pastel }
$$

$$
\text { Height, 81/2- inches; width, 61/4 inches }
$$

A portrart of a young and pretty lady who is seen head and bust in partial déshabillé. Her figure is facing the left, but she has turned her head so far to look back of her, over her left shoulder, that she is seen by the spectator almost full face. She wears a fluffy lace ruche around her neck, detached from her gray dress, which, falling from her shoulders, exposes part of breast and arm. Her light brown hair is dressed high over her forehead, she has large blue eyes, and she holds before her a loose bouquet of large pink roses.

signed at the lower right, J. Machard. 


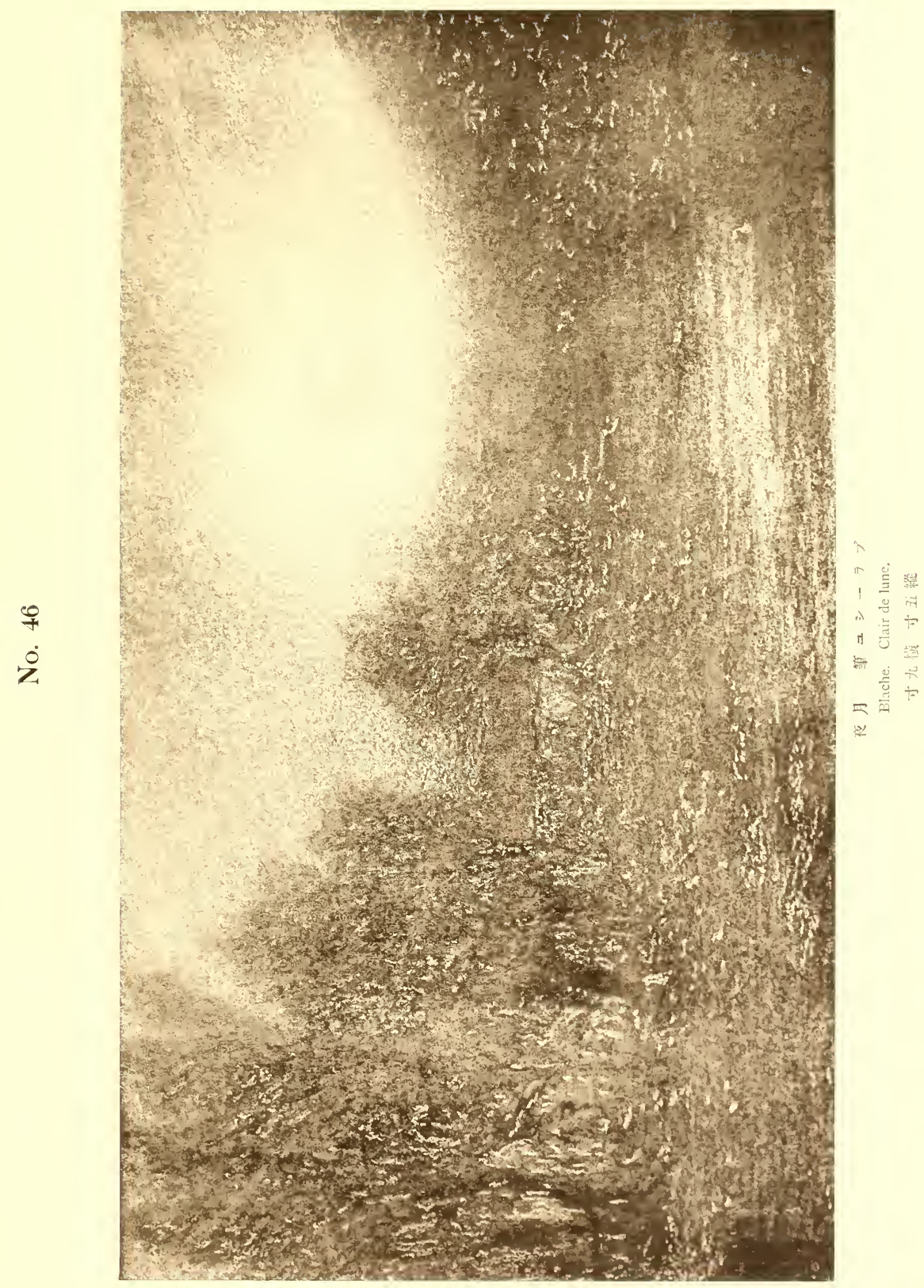


No. 46

\section{PHILIPPE CHARLES BLACHE}

FRENCH

Deceased

CLAIR DE LUNE

$$
\text { Pastel }
$$

Height, 61/4 inches; length, 11 inches

Trees and houses of a countryside mingle in scarcely determinable form, in the dull light of a crescent moon which is partly obscured in an evening haze just above the horizon. In the foreground a shallow pool, or stream, its boundaries not distinguishable in the dusk, reflects the lunar light.

Signed at the lower left, and numbered 13. 


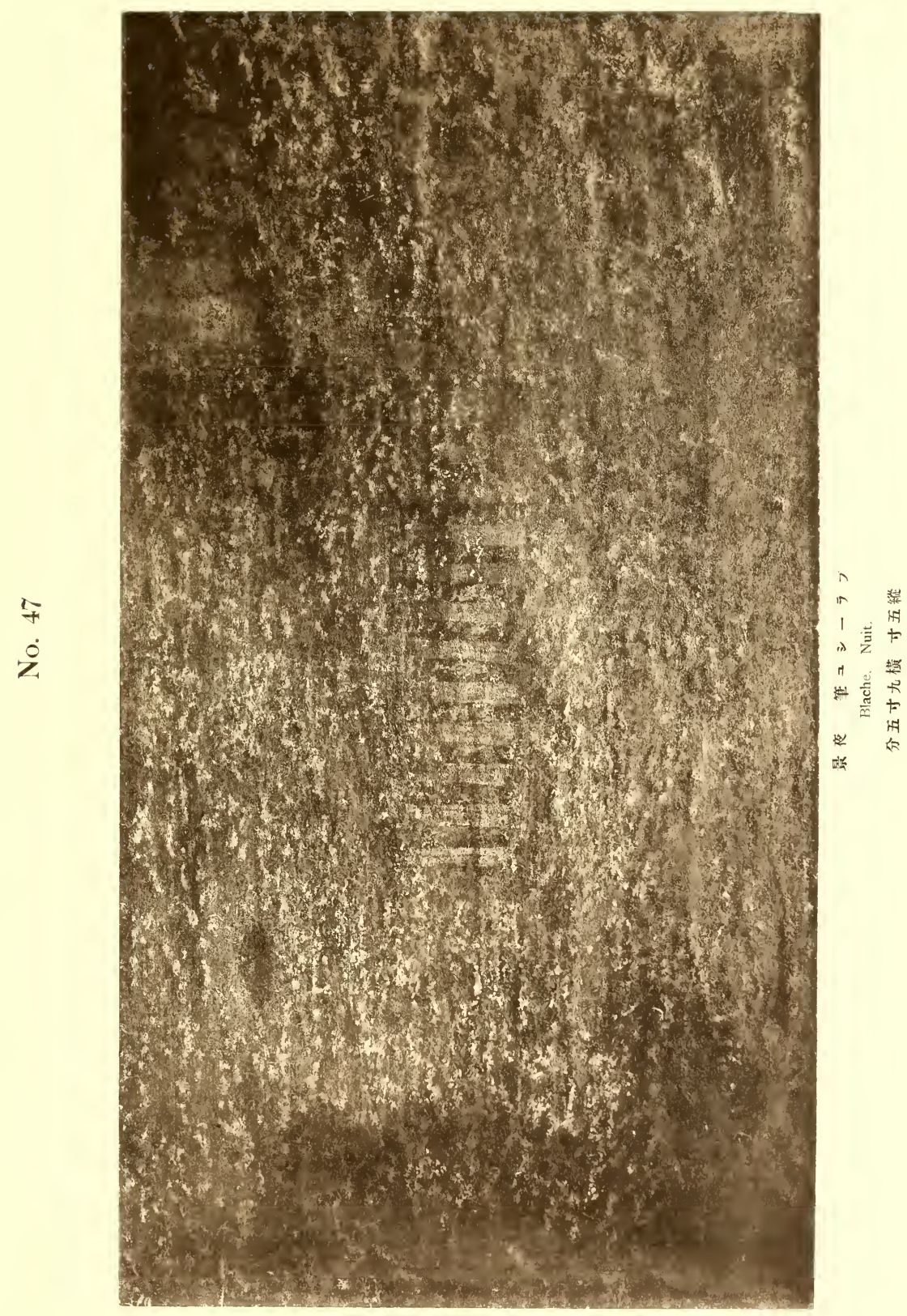


No. 47

\section{PHILIPPE CHARLES BLACHE} FRENCH

Deceased

NUIT

$$
\text { Pastel }
$$

Height, 6 inches; length, 111/2 inches

A GREE temple stands in the center of an obscure landscape on the far border of a small valley lake. Over a hill behind it the moon rises, a warm reddish-yellow, half of the full orb being seen above the blue hill-crest, and reflected, as are the pillars of the temple, in the still and silent waters of the lake.

Signed at the lower right, dated 1897 and numbered 48 . 


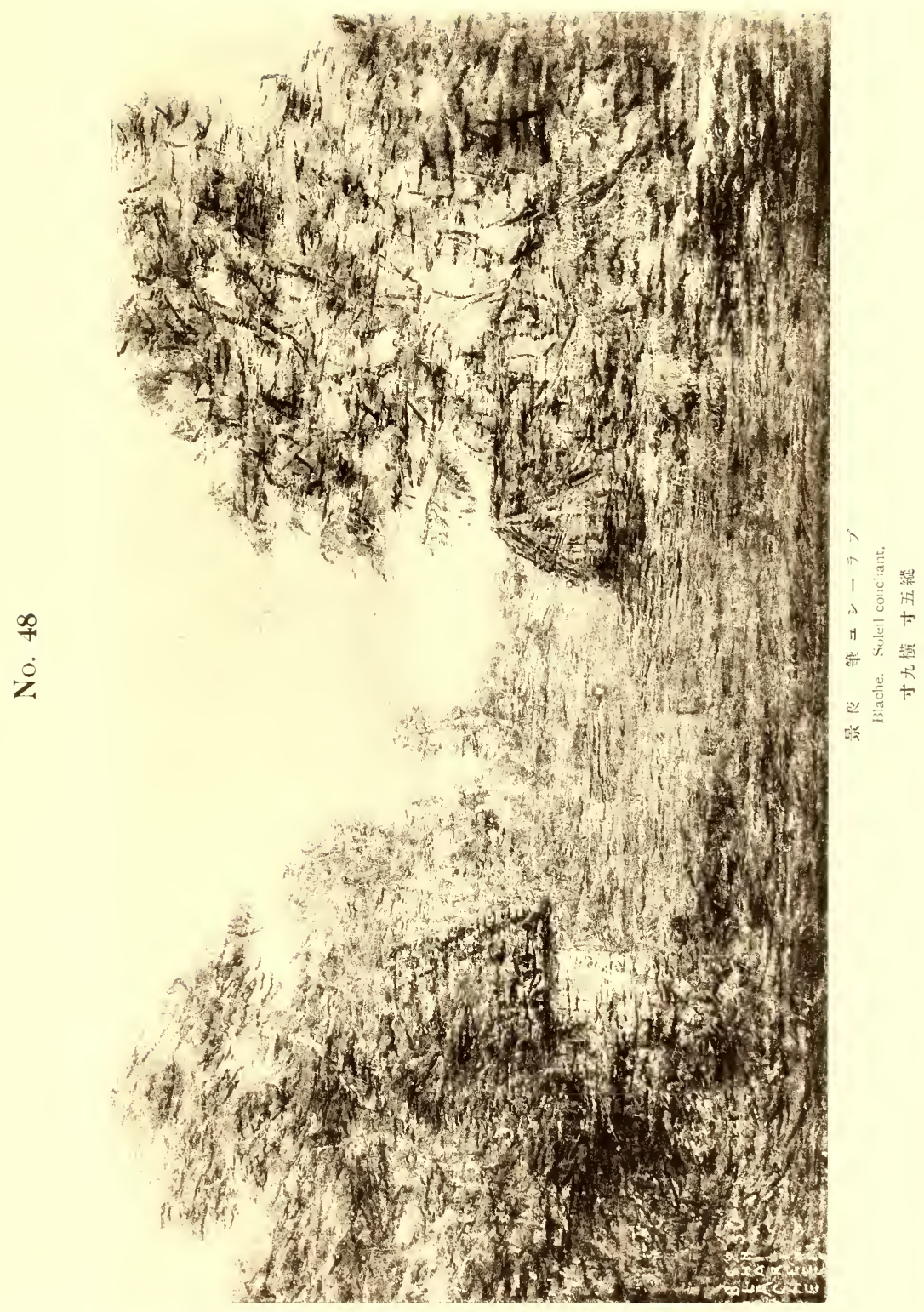


No. 48

PHILIPPE CHARLES BLACHE

FRENCH

Deceased

SOLEIL COUCHANT

$$
\text { Pastel }
$$

Height, 61/4 inches; length, 11 inches

A LANDSCape and sky of almost fantastic coloring, bathed in the varied lights of the close of day. The sky is striated, but with a predominant blue aloft, and a reddish-yellow glow appears over a blue mountain in the distance. In the foreground are to be seen buildings at either side, among the trees.

Signed at the lower left, dated 1894 and numbered 30. 


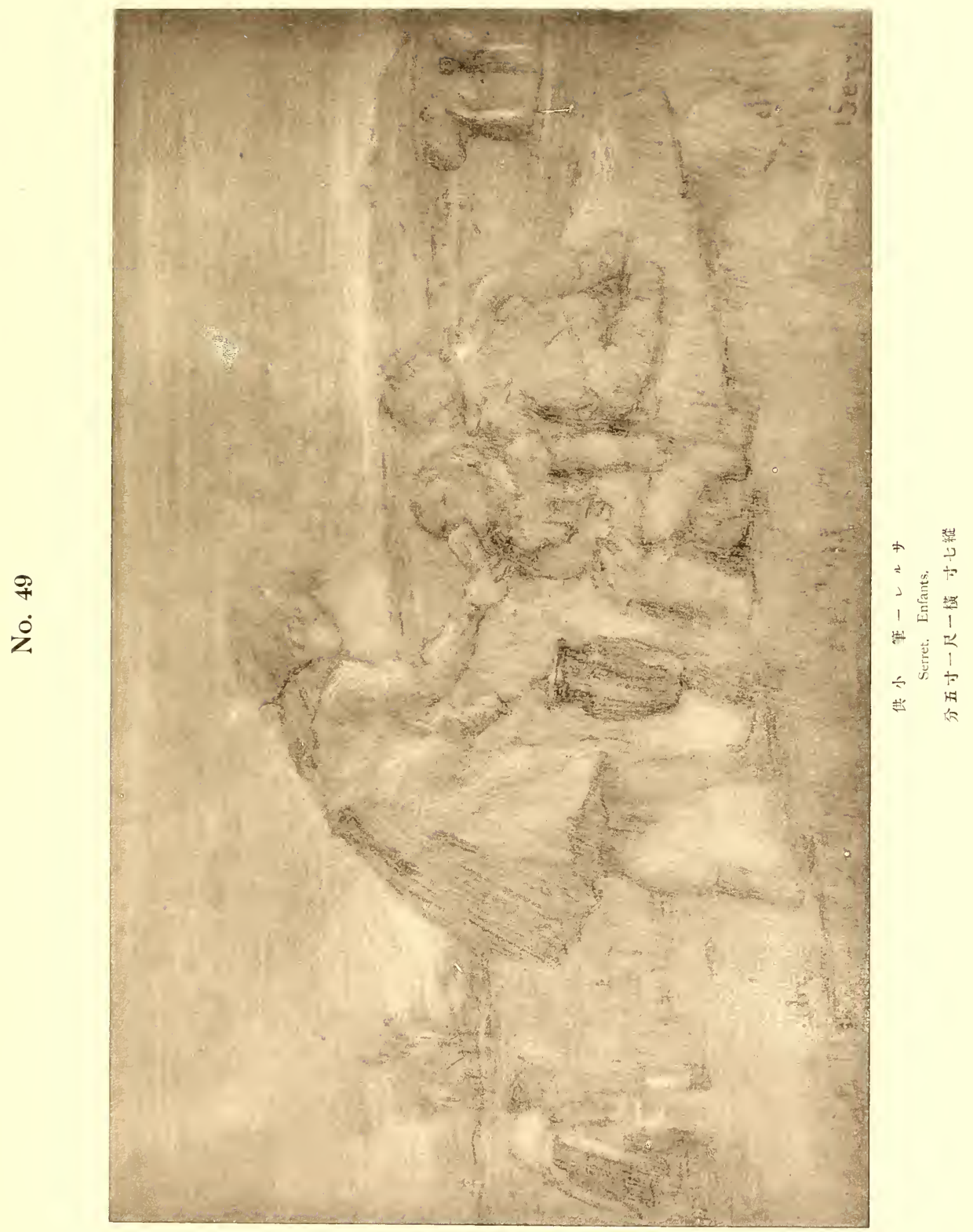


No. 49

\section{J. SERRE'T}

FRENCH

Contemporary

ENFANTS

Pastel

Height, 81/2 inches; length, 133/4 inehes

Two chubby infants, one in pink and one in blue, are perched upon a stone seat in the fields, where other children and their elders are laboring. A little girl somewhat older than the babes is giving them a drink of water from a bluish-green jar, bending over them in a graceful attitude - the tow-haired cherub who is awaiting his turn for the water gazing wide-eyed and solemnly up at her.

Signed at the lower right, Serret. 
No. 50

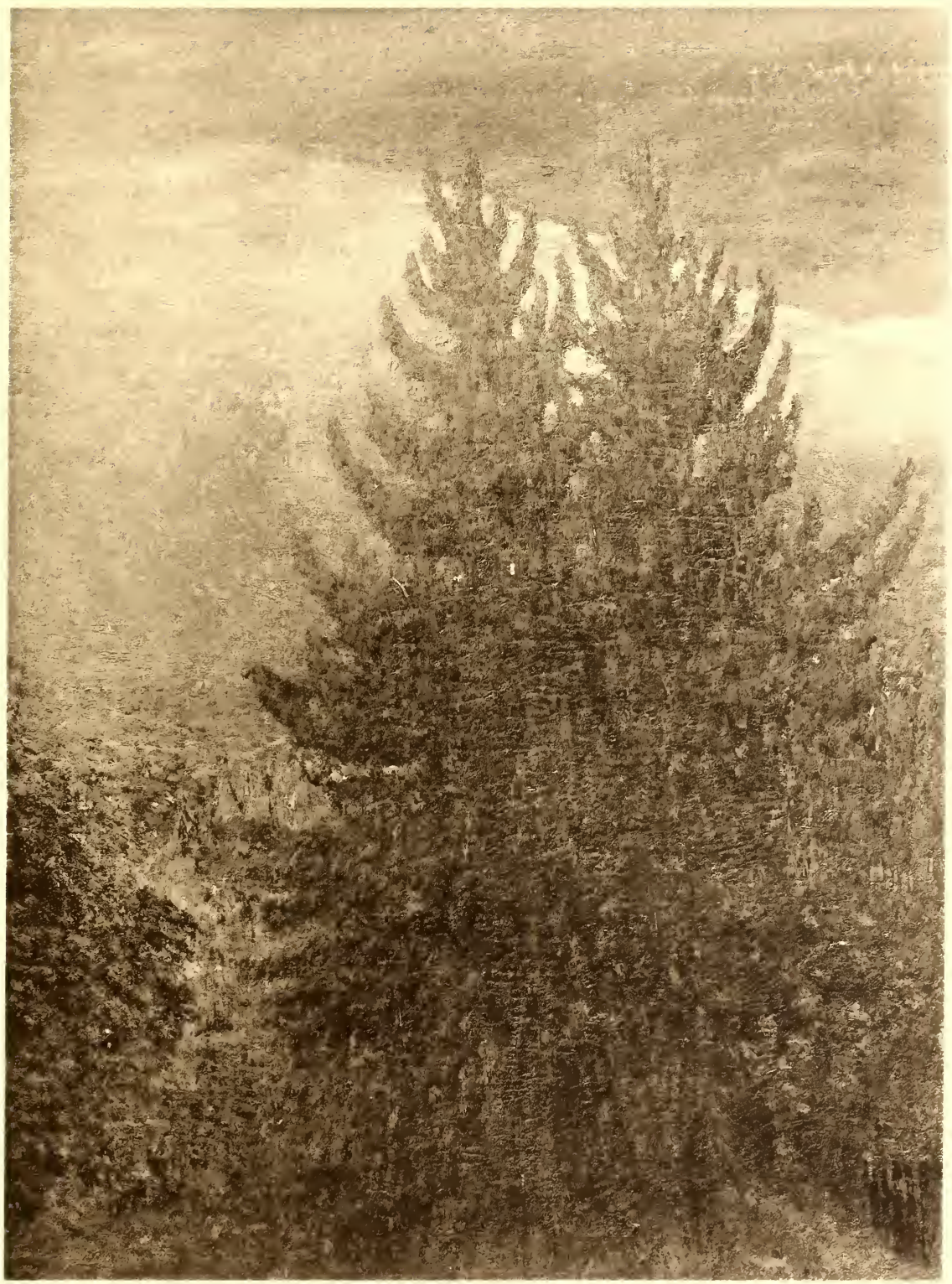

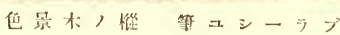

Blache. Paysage aux sapins.

寸八横寸一尺一船 
No. 50

\section{PHILIPPE CHARLES BIACHE}

FRENCH

Deceased

PAYSAGE AUX SAPINS

$$
\text { Pistel }
$$

Height, 123/4 inches; width, 91/2 inches

'Tinsk trunks are brown and their green branches exhibit blue lights, but as to their general configuration the two tall fir trees, which grow in the foreground of the picture, rise in strong silhouette against a light-flooded mountain side which is seen across a valley, all aglow in flame-hue, yellow and purple.

Signed at the lower right, dated 1884 and 1896 and numbered 38. 
No. 51

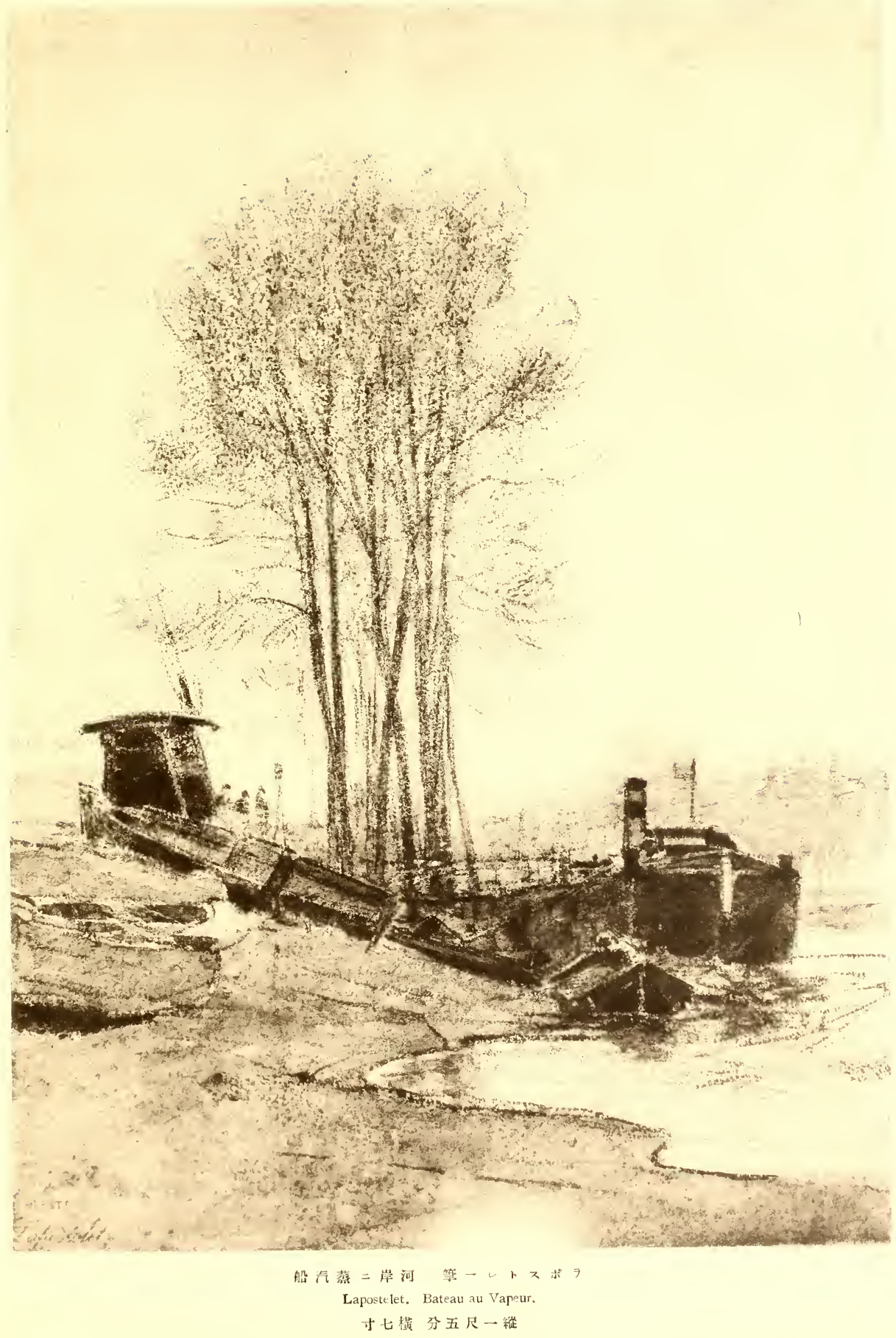


No. 51

\section{CHARLES LAPOSTOLET}

FRENCH

1824-

\section{BATEAU A YAPEUR}

Pastel

Height, 121/4 inches; width, 81/4 inches

Sose trees which have grown in a group on the shore of a stream occupy the middle distance, toward the left, with some men standing back of them in the shelter of a low tower. To the right of the trees a freight steamer is moored, at the bankside, and ahead of it some small boats have been hauled out on the sloping foreground shore.

Stamped at the lower left, Vente Lapostolet. 
No. 52

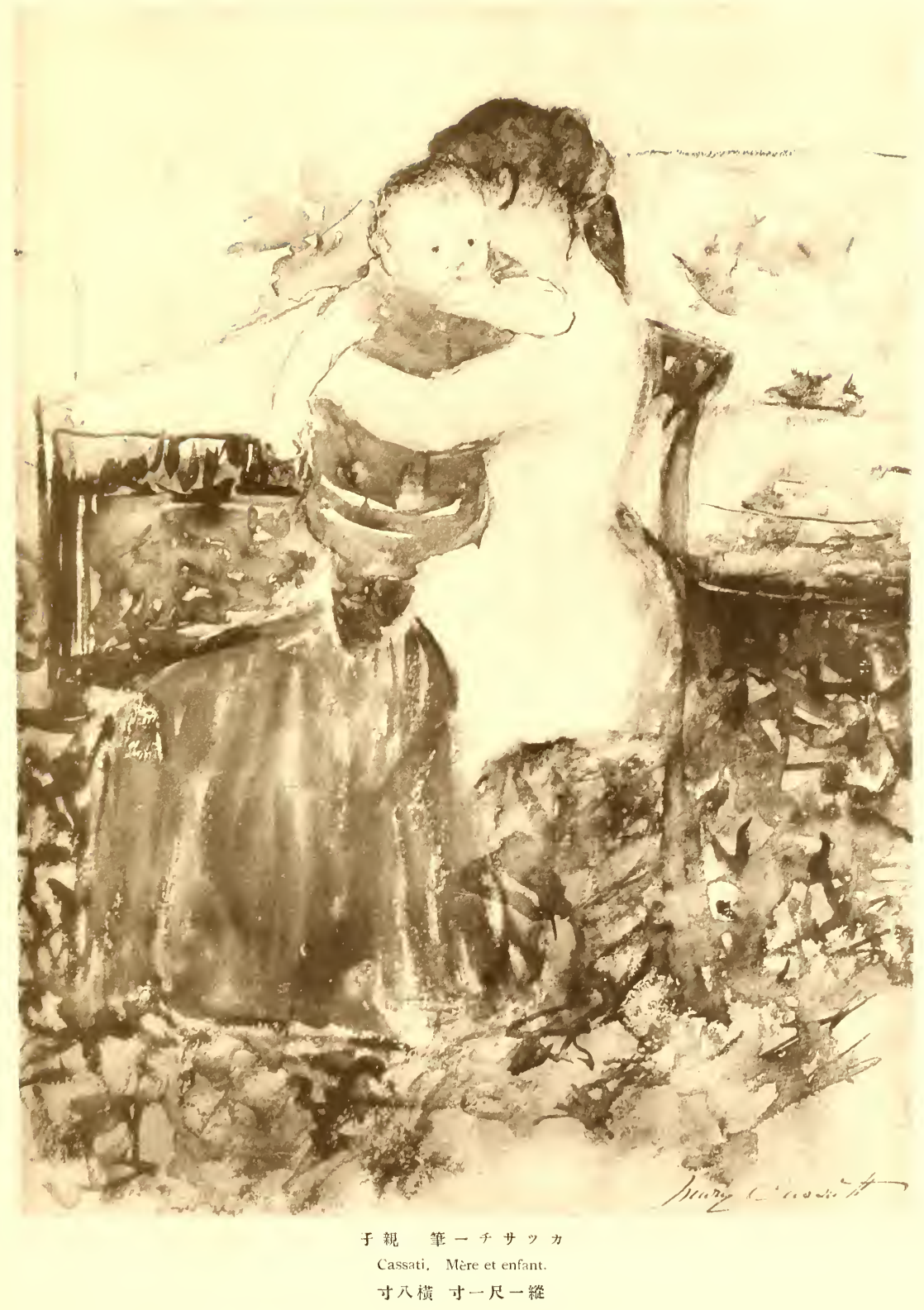


No. 52

\title{
MARY CASSA'T'I
}

\author{
AMERICAN \\ Contemporary
}

MERE E'T ENHANT

Water Color

Height, 121/2 inches; width, 91/2 inches

A mother wearing a gray-white gown is seated in a chair of a bedroom, one arm clasped about her chubby infant, who in a deep blue frock stands on her: lap with one fat arm on the mother's shoulder. 'The mother is seemingly in the act of undressing her child. The baby, finger in mouth, wears a very intent expression, though looking into distance, and his round head hides his mother's face from view.

Signed at the lower right, Mary Cassatt. 


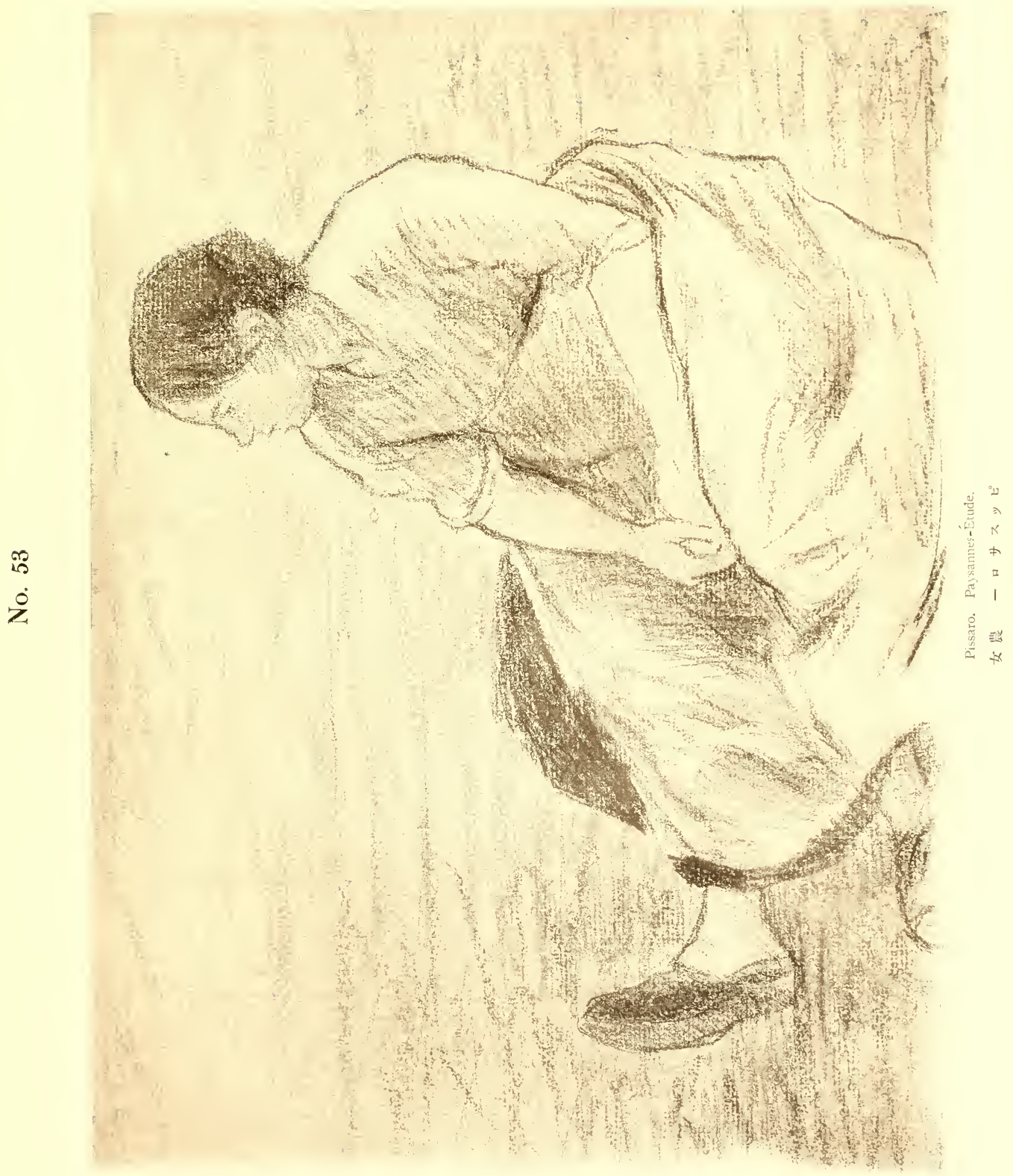


No. 53

\section{CAMILLE PISSARRO}

FRENCH

1810-1903

PAYSANNE-ÉTUDE

$$
\text { Pastel }
$$

Height, 91/4 inches; length, 12 inches

THis study is of the full-length figure of a peasant woman in a bluish-green dress, blue stockings and clumsy shoes, seated lazily on the ground, her hands clasped in her lap, and gazing afar off. She has yellowish-red hair and is seen in profile, turned to the left. Presented to Tadamasa Hayashi by the artist.

Signed at the lower left, C. Pissarro, 1890. 
No. 54

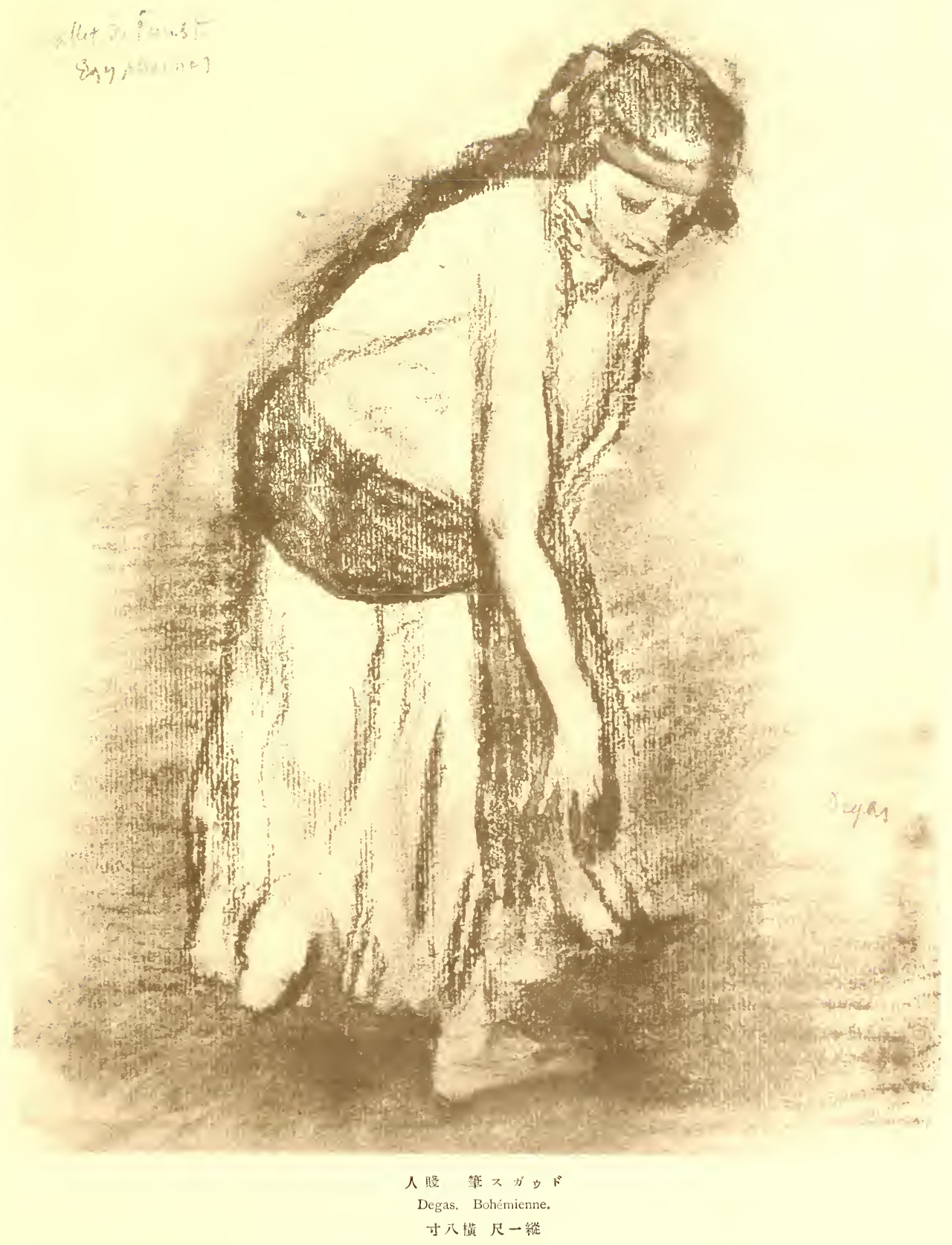


No. 54

HILAIRE GERMAIN EDGAR DEGAS

FRENCH

18:34-

"BOHEMIL'NVE"

$$
\text { Pastel }
$$

Height, 12 inches; width, 91\% inches

'TuE title given to this picture, whether taken as meaning gipsy, or as meaning a Bohenian, seems to be a mistaken one, both from the costume and an inscription in the upper left hand corner which reads "Baliet de Faust-Egyptiennes." 'Though written in a hand resembling that of Degas in his signature, howerer, this inscription is further confusing as there is no Egyptian ballet in "Faust," - and the artist would hardly write "Faust" if he were thinking of "Aïla." It requires no caption, however, to make the expressive drawing clear.

One of Degas's strangely drawn figures of the stage,this one a heary, sturdy, woman dancer, in a flowing, semi-transparent robe girdled by a broad red sash, corresponding to her red headdress, with her brow bound in light yellow. She is seen in a peculiar attitude, partly back to the spectator, but turned about so that her face, as she leans over as though to pick up something, is threequarters to the front.

Signed at the lower right, Degas. 
No. 55

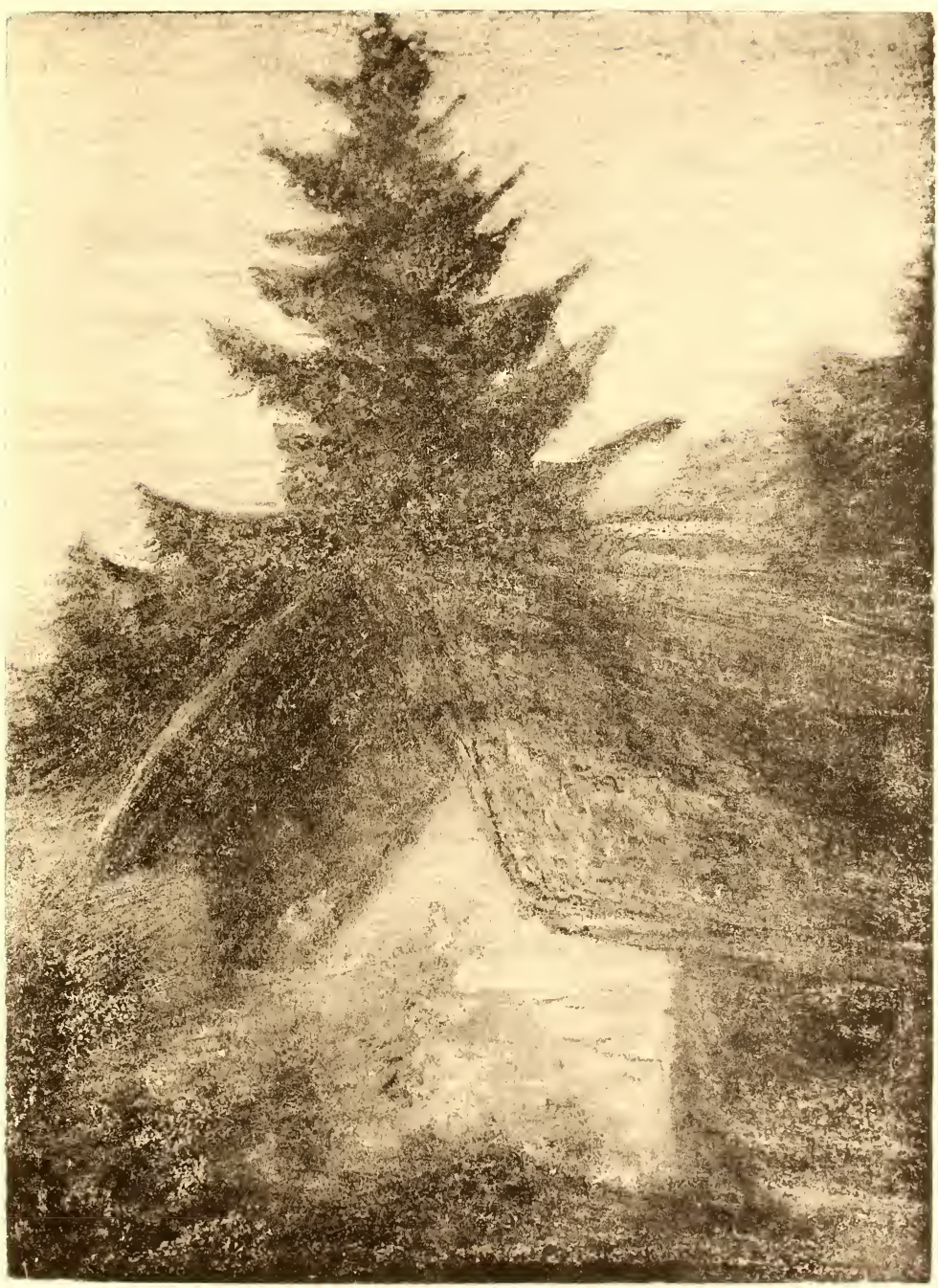

稄月箯ュシーラプ

Blache. Chair de lune.

分五寸比横 尺一檤 
No. 55

\section{PHILIPPE CHARLES BLACHE}

FRENCH

Deceased

CLAIR DE LUNE

$$
\text { Pastel }
$$

Height, 12 inches; width, 9 inches

A whitened cottage, its thatched roof purplish-brown in the moonlight, occupies the foreground, and with a tall pine tree that rises behind it, high in silhouette above the lowly ridgepole, almost fills the picture. An end of the house and the sky beyond the pine tree are bathed in a cool, greenish, lunar glow. 


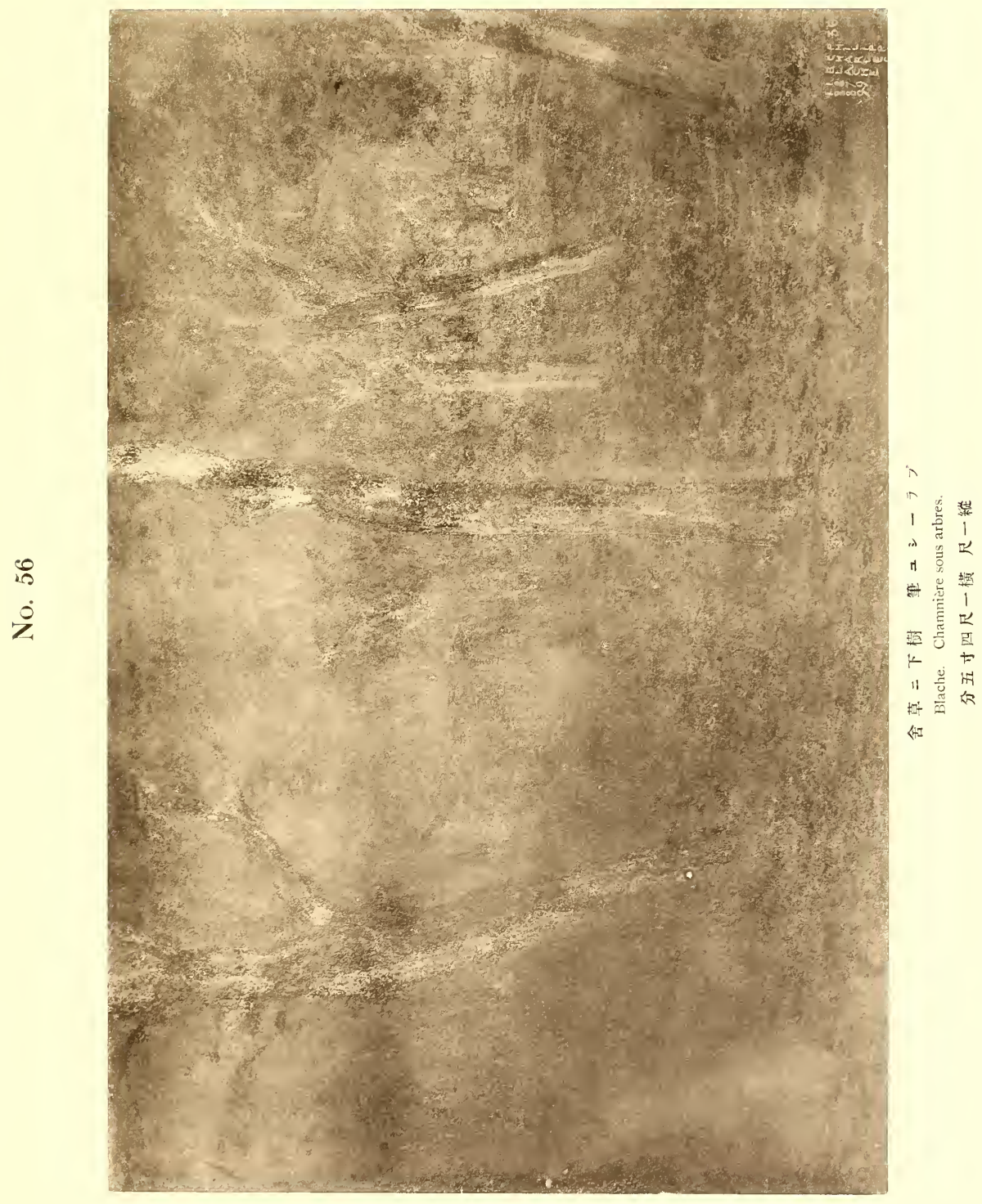


No. 56

\section{PHILIPIE CHARLES BLACHE}

FRENCH

Deceased

\section{CHAUMIERE SOUS ARBRES}

Pastel

Height, $111 \%$ inches; length, 171\% inches

A Hut appearing dilapidated but nevertheless attractive stands amid a grove of low-branching trees, which throw the ground between them into deep shade, while beyond the cabin a flood of light bursts among the farther trees, in a golden contrast to the cool green of the shaded nook.

Signed at the lower right, dated 1879 and 1889, and numbered 36. 


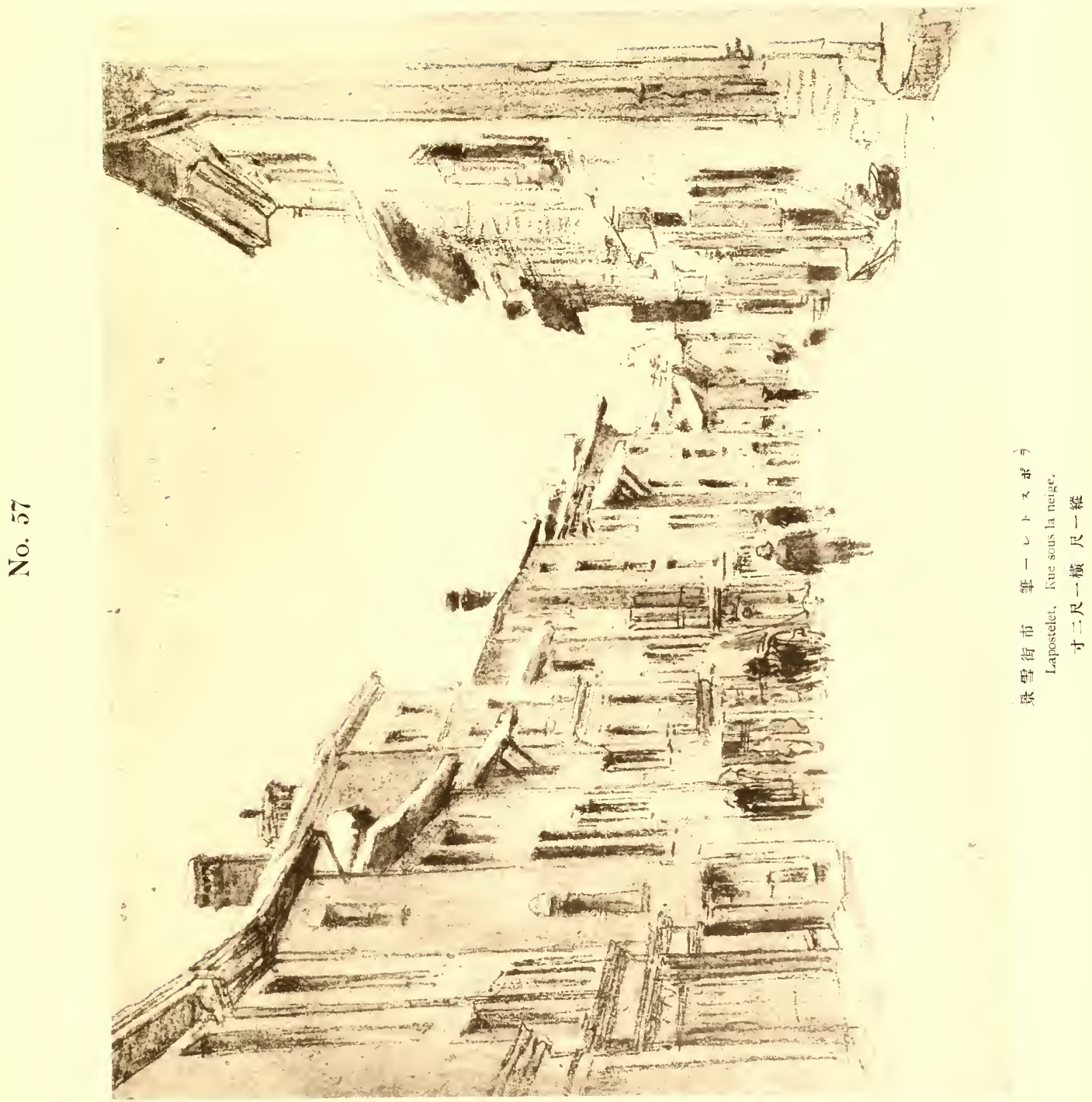


No. 57

\section{CHARLES LAPOS'TOLE'T}

FRENCH

1824

RUE SOUS LA NEIGE

Pastel

Height, 12 inches; length, 141/4 inches

IT is a dull winter day, with just enough snow fallen to whiten the eaves and drift in low hummocks at the curb and against doorsteps, in the winding street of an ancient town with picturesque and irregular architecture. Some of the green shutters have been put up, and a few straggling pedestrians make their several ways slowly homeward.

Stamped at the lower right, Vente Lapostolet. 
No. 58

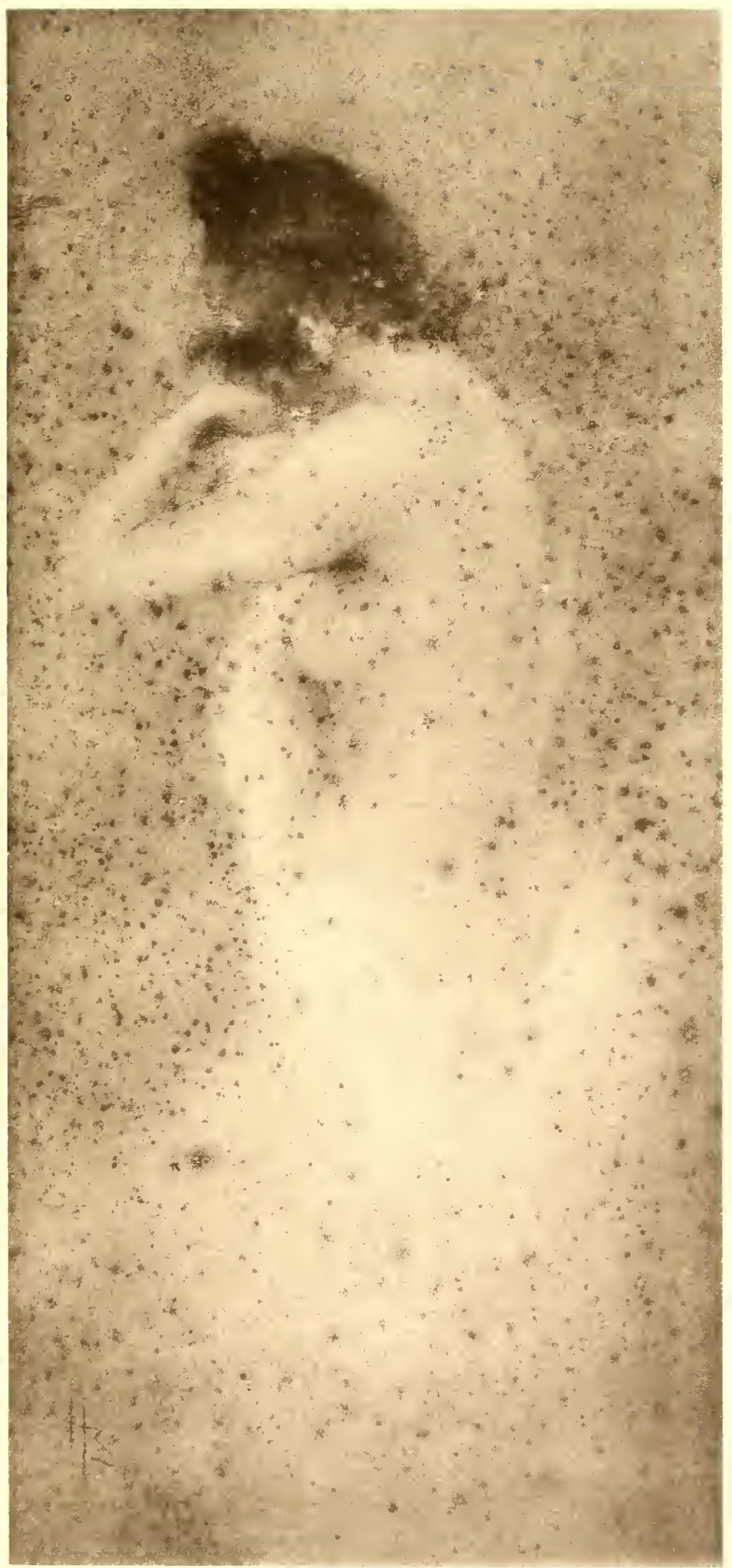

人婦體裸等一デーン

Sauter. Femme nue.

寸七橫 寸五尺一䊓 
No. 58

\section{H. SALTER}

FEM ME NUE

$$
\text { Pastel }
$$

Itcight, 18 inehes; width, 8 inehes

Three-quarter length presentation of a tall woman of full figure, standing mude. facing the left and so far turned about that her back is brought three-quarters into view. Her brown hair is done up over her head. Her left arm, raised shoulder high, is bent back at the elbow so that her hand supports and partly conceals her face.

Signed at the lower left, H. Sauter. 
No. 59

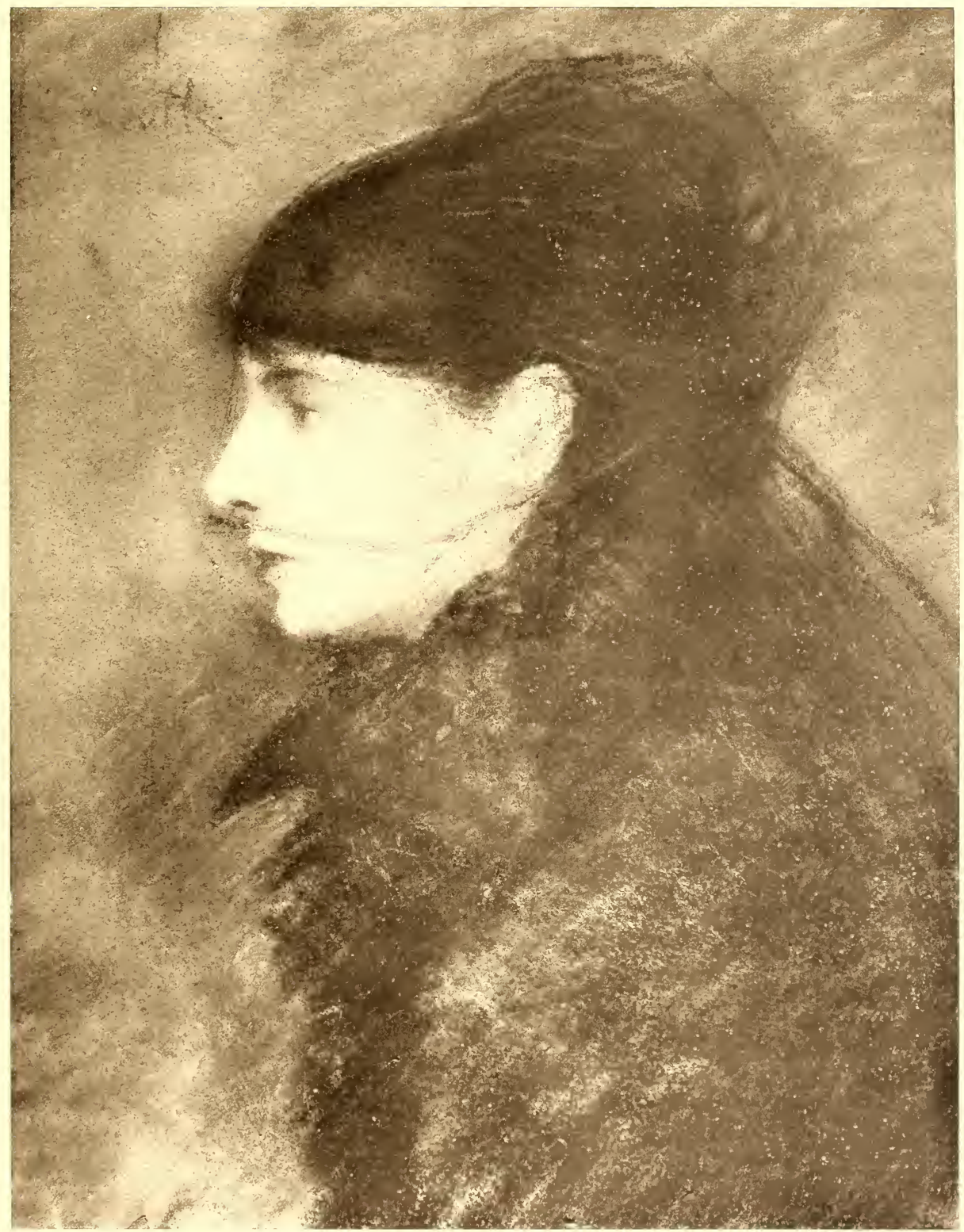

女, 在黑等トッコンーエヂ

Goencotte. Dame en noir.

尺一横 寸三尺一縱 
No. 59

\section{NORBERT GOENEU'T'TE}

FRENCH

18.54-1894

\section{DAME EN NOIR}

$$
\text { Pastel }
$$

Height, 153/4 inehes; width, 121/4 inehes

Tru lady is seen in profile, facing the left, the artist having pictured her head and shoulders. She is young, of listless countenance, and pale, with rouged lips, and her yellow hair is dressed low on her forehead, all but overhanging her eyes. She is hatless, but with a veil about her head and half covering her face, and she wears a black wrap.

Signed at the upper left, N. Ganeutte. 


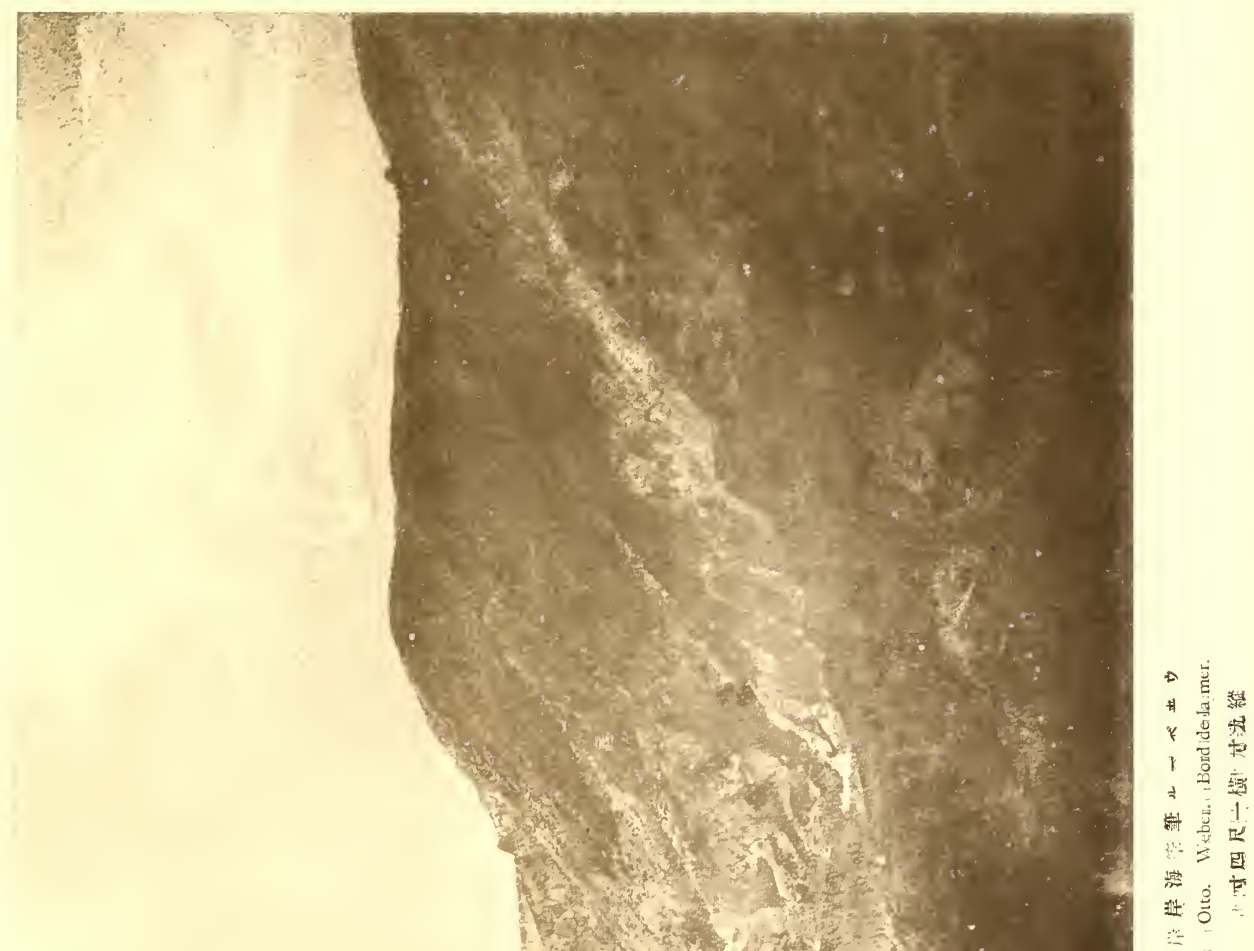


No. 60

\section{OTTO WEBER}

GERMAN

1823-1888

BORD DE LA MER

Water Color

Height, 11 inches; length, 16 inches

THe deep bluish-green water of the sea comes up gently at the left, mildly splashing in thin lines of white foam upon outlying rocks along the edge of a boldly rolling coast line. The day is sombre, dull gray clouds sagging low, and the more or less barren coast, with its faded green and red-sandy hues, appearing dull in sympathetic dejection.

Signed at the lower right, Otto Weber. 
No. 61

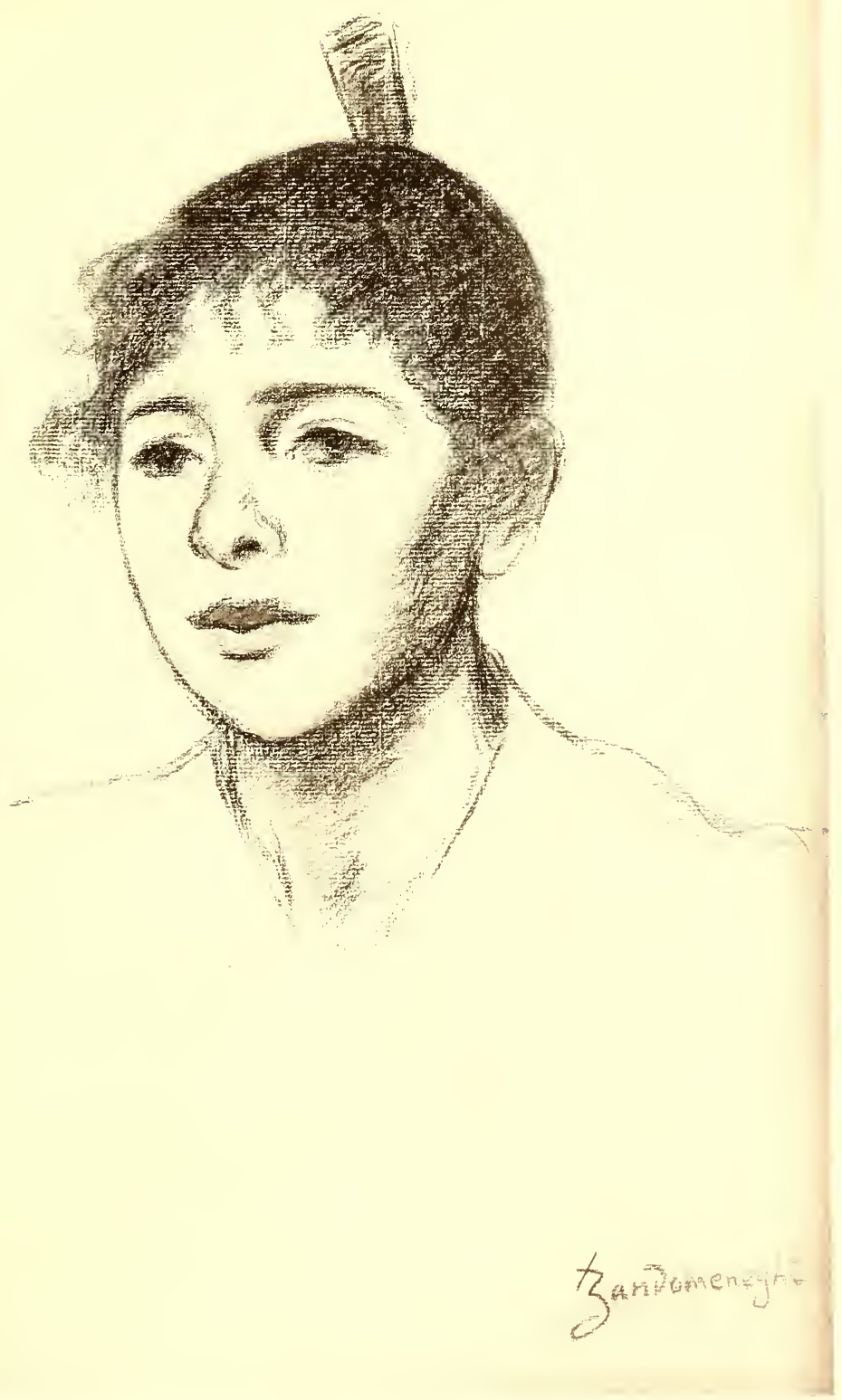

身牛女處算クッホメドンアッ゙

Zandomeneghi. Téte de jenne fille.

尺一蓝寸四尺一樅 
No. 61

FEDERICO ZANDOMENEGHI

ITALIAN

$18+1$ -

TETE DE JEUNE FILLE

Pastel

Height, 163/4 inches; width, 111/2 inches

THE head of a pug-nosed young girl, seen full face but turned slightly to her right, her eyes directed somewhat downward. Her dark hair exhibits reddish lights over her forehead, and she wears a light blue waist, loosened at the neck.

Signed at the lower right, Zandomeneghi. 
No. 62

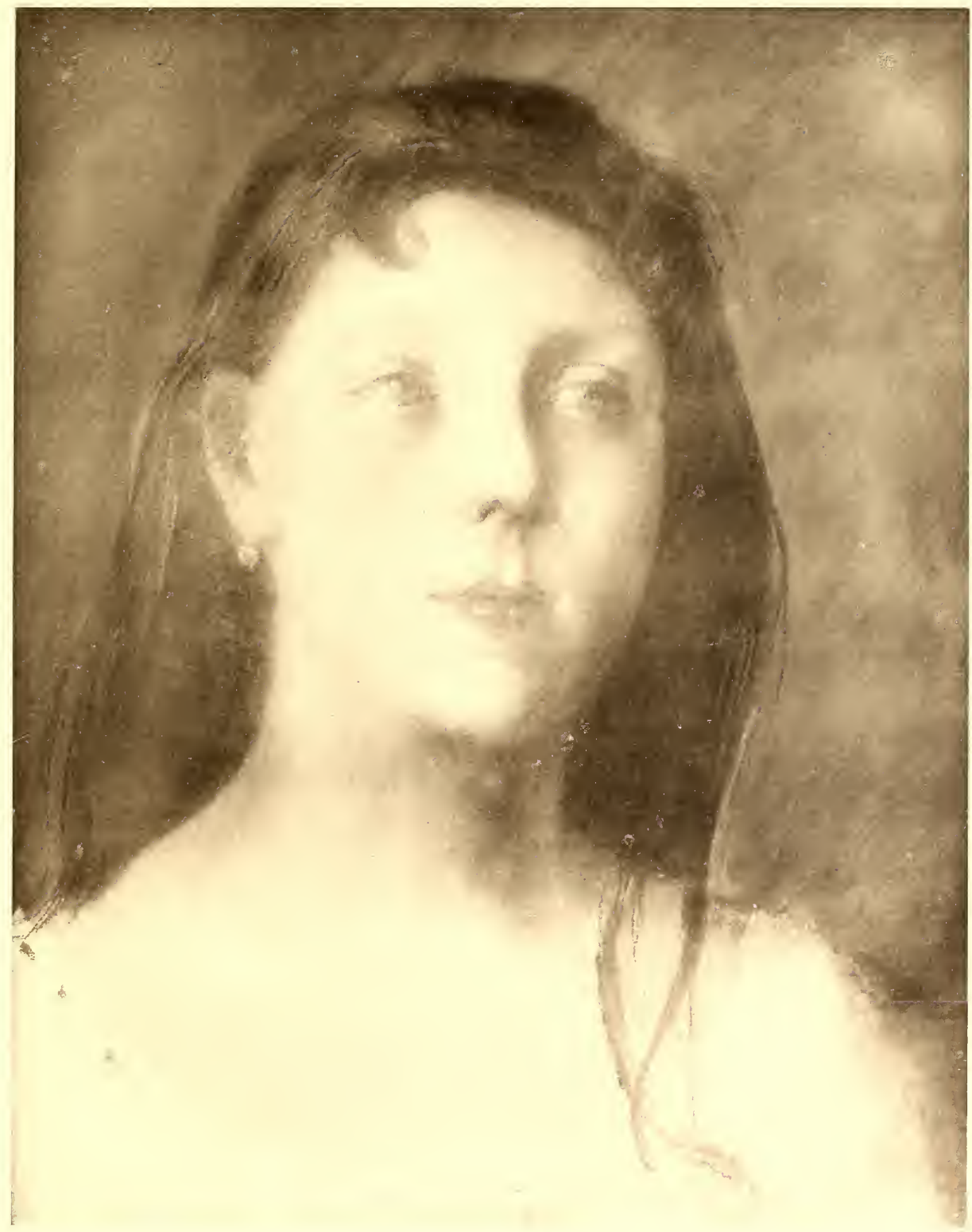

女起䇤ジッ卒メトンアッ

Zandomeneghi? Tête de jeune fille sur fondvert.

尺一横分五寸二尺一縱 
No. 62

\section{FEDERICO ZANDOMENEGHI \\ ITALIAN}

1841 -

TETE DE JELNE FILLE, SUR FOND VERT

Pastel

Hcight, 151/4 inches; width, 12 inches

'THE young girl, shown head and shoulders, wears a white frock which falls well away from her neck and clings over the shoulders. Her brown hair, brushed carelessly from her forehead and draped loosely down her back, frames her fair face-with its deep blue eyes-against a background of solid green. She appears almost full face, turned slightly to her left, whither her gaze is directed, and exhibits in her right ear a blue earring. 
No. 63

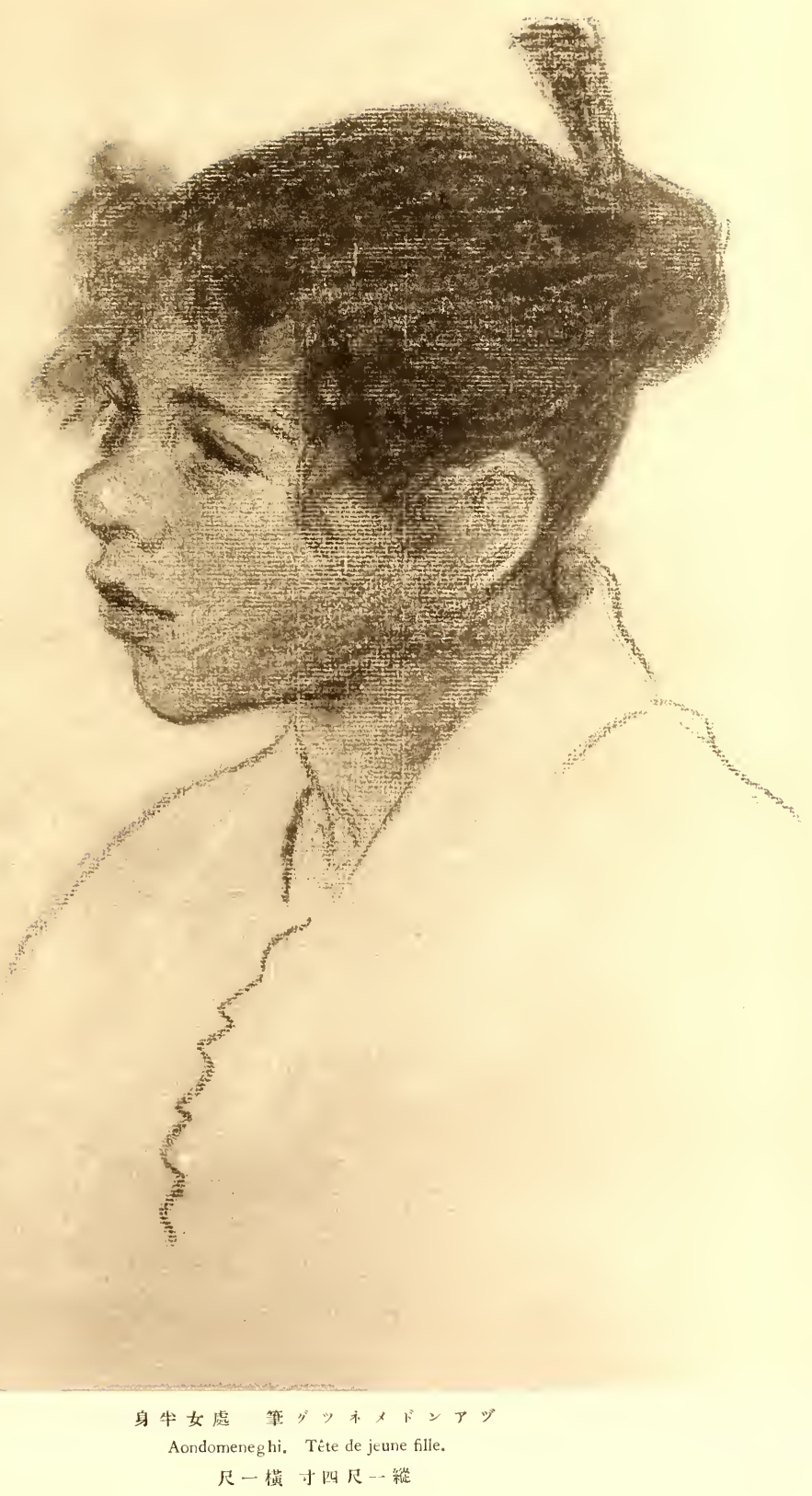


No. 63

\section{FEDERICO ZANDOMENEGHI \\ I'TALIAN}

$18+1-$

\section{TE'TE DE JEUNE FILLE}

Pastel

Height, 16\%3 inches; width, 111\% inches

A roung girl of peasant type, dressed in a loose, blue house jacket, is shown head and shoulders and facing threequarters to the left, so that her face is seen almost in profile. She has blue eyes, full red lips and red cheeks, and a retroussé nose; and her black hair, through which greenish lights play, is done up in a saucy knot and decked with a bit of red. 
No. 64

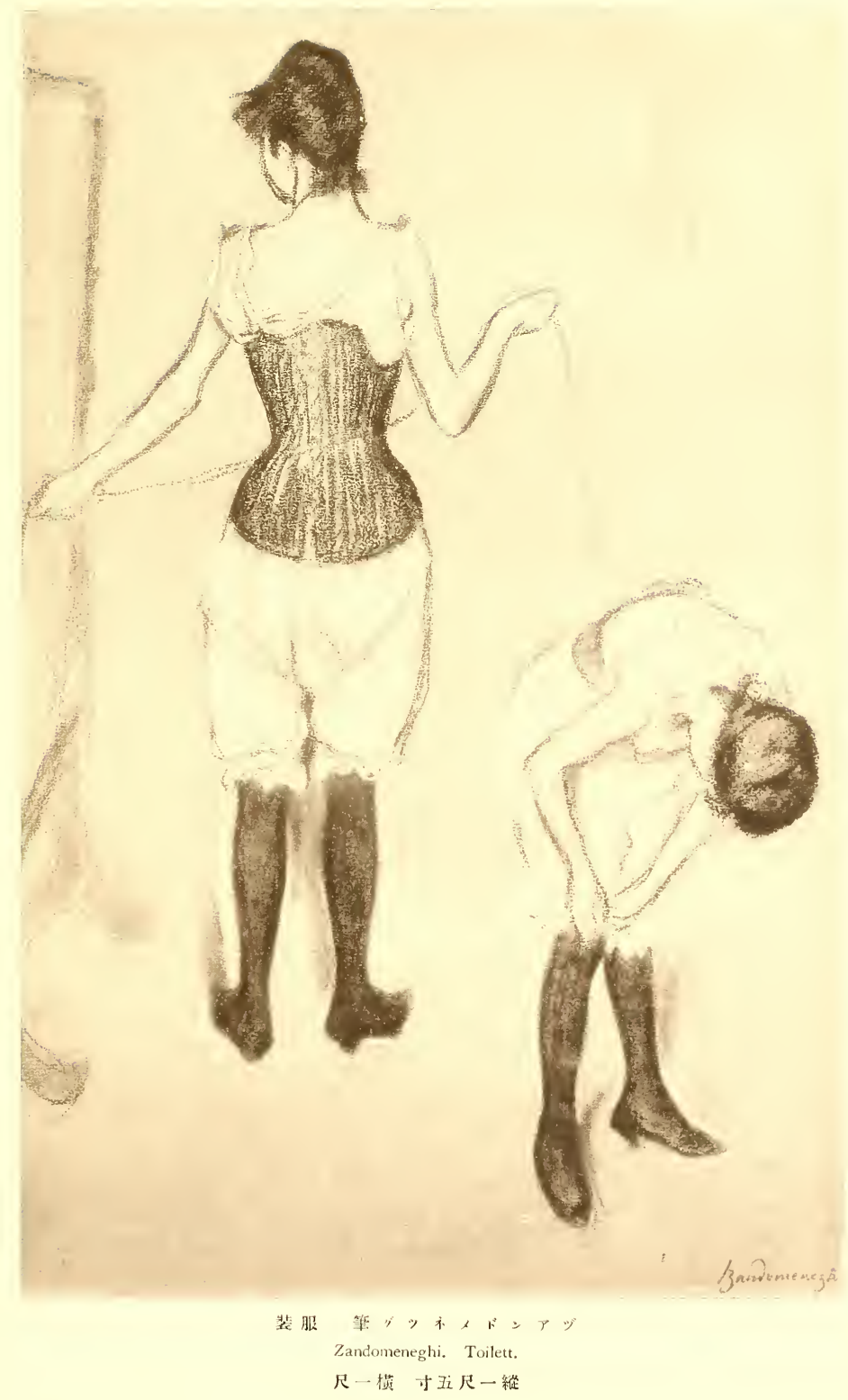


No. 64

\section{FEDERICO ZANDOMENEGHI \\ ITALIAN \\ $1841-$}

TOILETTE

Pastel

Height, 18:3/4 inches; width, 12 inches

Two young women are shown in their dressing room at their toilette, one adjusting her corsets before her psyché; she stands back to the spectator, her head turned to the left to look into the mirror. Her comrade who stands near by-her own toilette no further progressed - is leaning forward, at the moment, arranging her garter, her head so far lowered that her face is not seen.

Signed at the lower right, Zandomeneghi. 


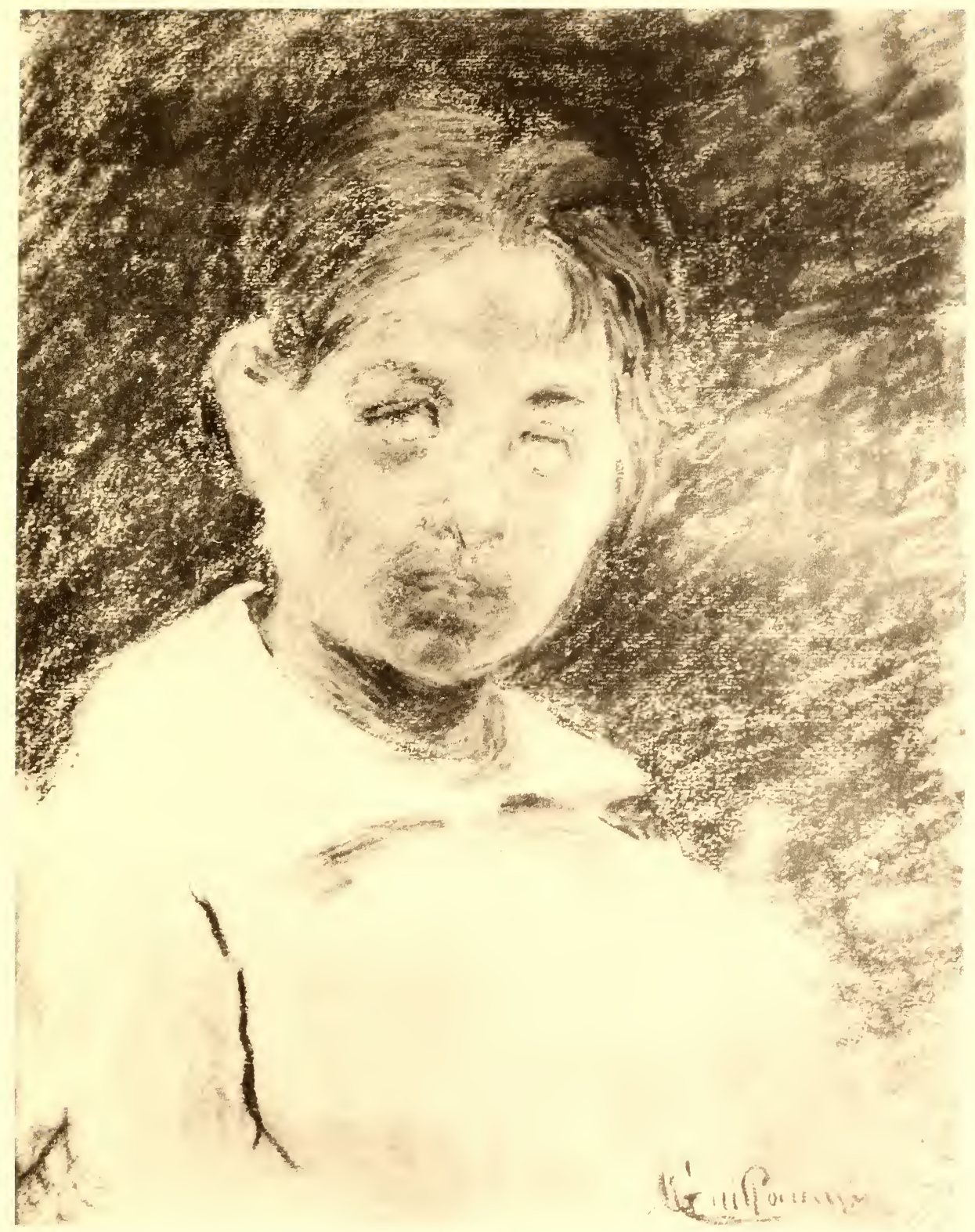

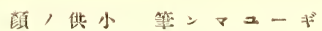

Guillaumin. Tête d'enfant. 
No. 65

\section{ARMAND GUILLAUMIN}

FRENCH

1841-

\section{TE'TE D'ENFANT}

$$
\text { Pastel }
$$

Height, 15 inches; width, 113/4 inches

A sarall girl with an interesting face and prominent features appears in head and shoulders against a light and dark green background, the curiously variant lights of out-of-doors playing upon her serious face and unkempt hair-an early plein air exposition.

Signed at the lower right, Guillaumin, '79. 
No. 66

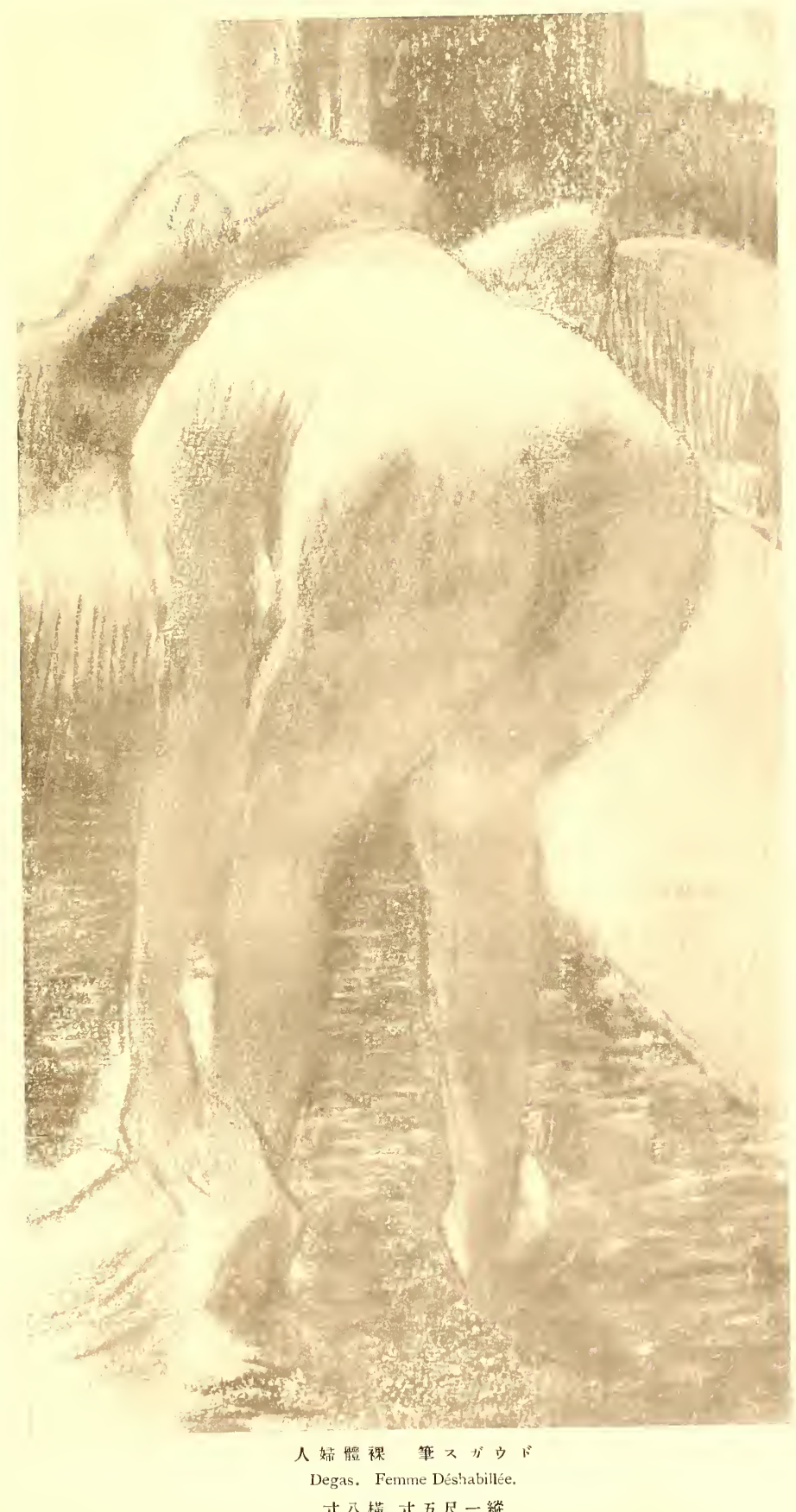


No. 66

HILAIRE GERMAIN EDGAR DEGAS

FRENCH

$1834-$

FEMUE DESHABILLEE

Pastel

Height, 171/2 inches; width, 91/4 inches

A stout woman, nude, just energed from the bath, her back turned to the spectator, leans forward, supporting herself with one arm on the furniture while with the other hand, extended, she is drying her foot with a towel. A study of flesh against blue tones, and warm reds on the floor and wall.

Signed at the right, Degas. 


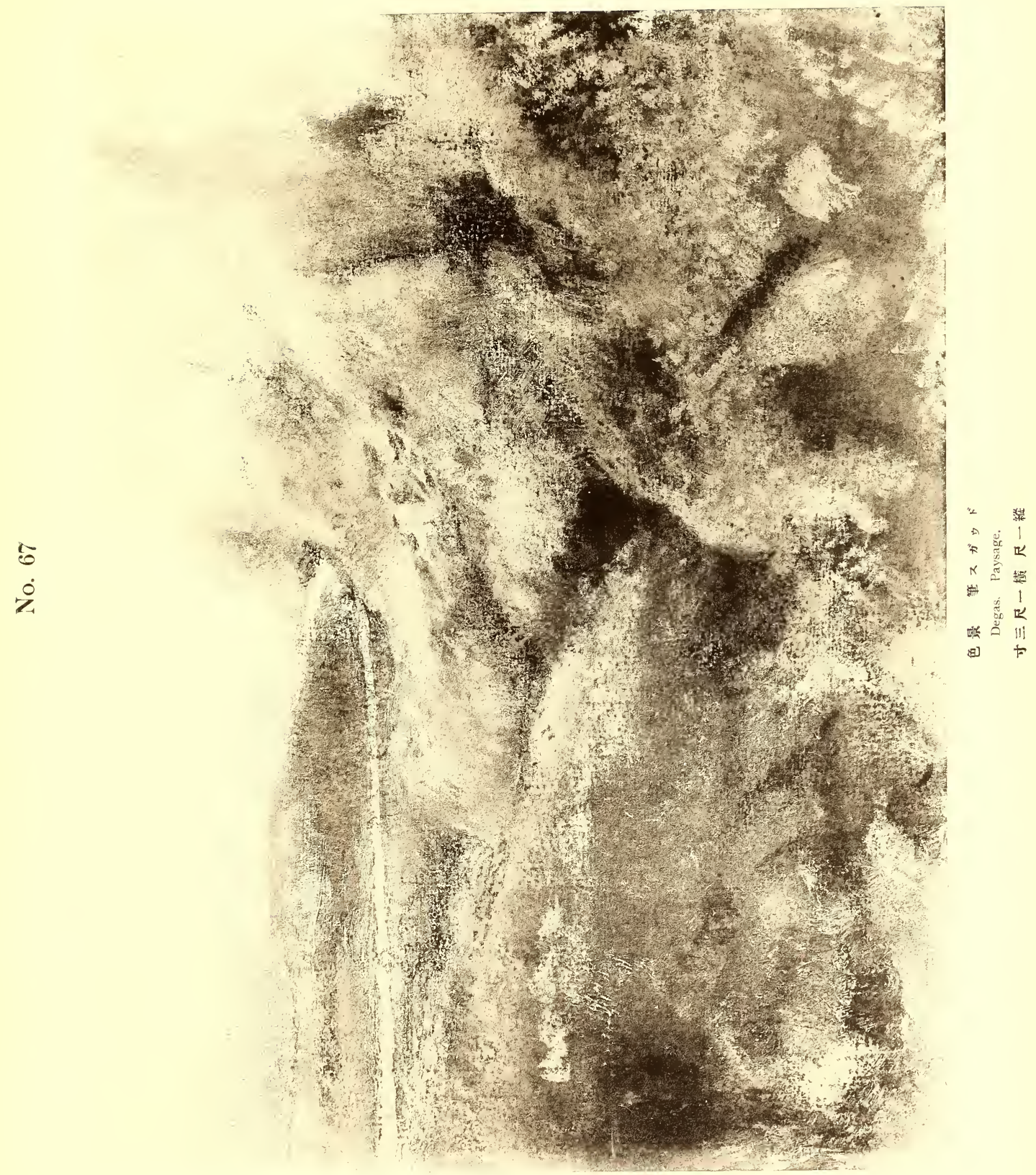


No. 67

\section{HILAIRE GERMAIN EDGAR DEGAS}

FRENCH

1834-

PAYSAGE

$$
\text { Pastel }
$$

Height, 111/2 inches; length, 151/2 inches

A sTEEP, seamed and rocky acclivity rises at the right, mounting out of the picture, from a colorful and varied, but inhospitable and uninviting foreground. From the left a road entering the middle distance and winding about a knoll, conveys an intimation of a habitable country somewhere beyond. A landscape of ruggedness and rigor.

Signed at the lower right, Degas. 

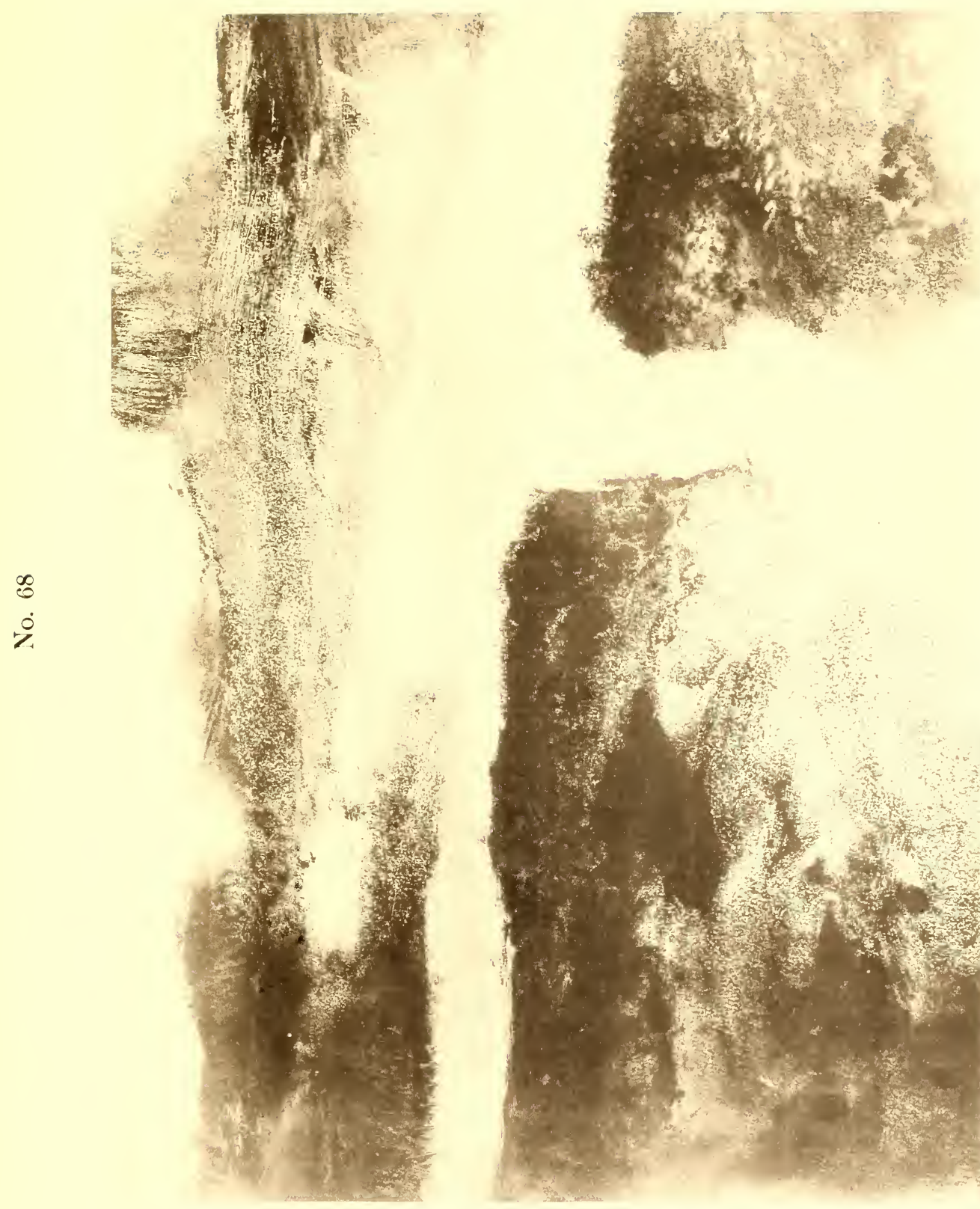

"- 氙

$\begin{array}{lll} & 0 & 0 \\ \therefore & 0 & 0\end{array}$

$<\geqslant$

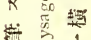

ब

兴宫 111

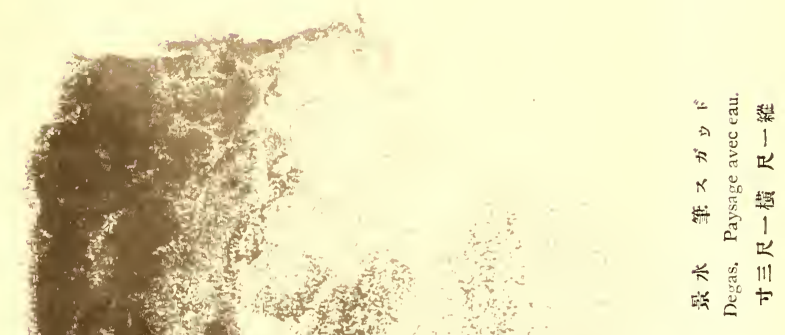


No. 68

\section{HILAIRE GERMAIN EDGAR DEGAS}

FRENCH

1834 -

PAYSAGE AVEC EAU

Pastel

Height, 113/4 inches; length, 151/2 inches

A strean with its confluent and a narrow offshoot is pictured in a more or less barren landscape, which it makes interesting through the odd forms arranged by its intersecting liquid lines.

Signed at the lower left, Degas. 


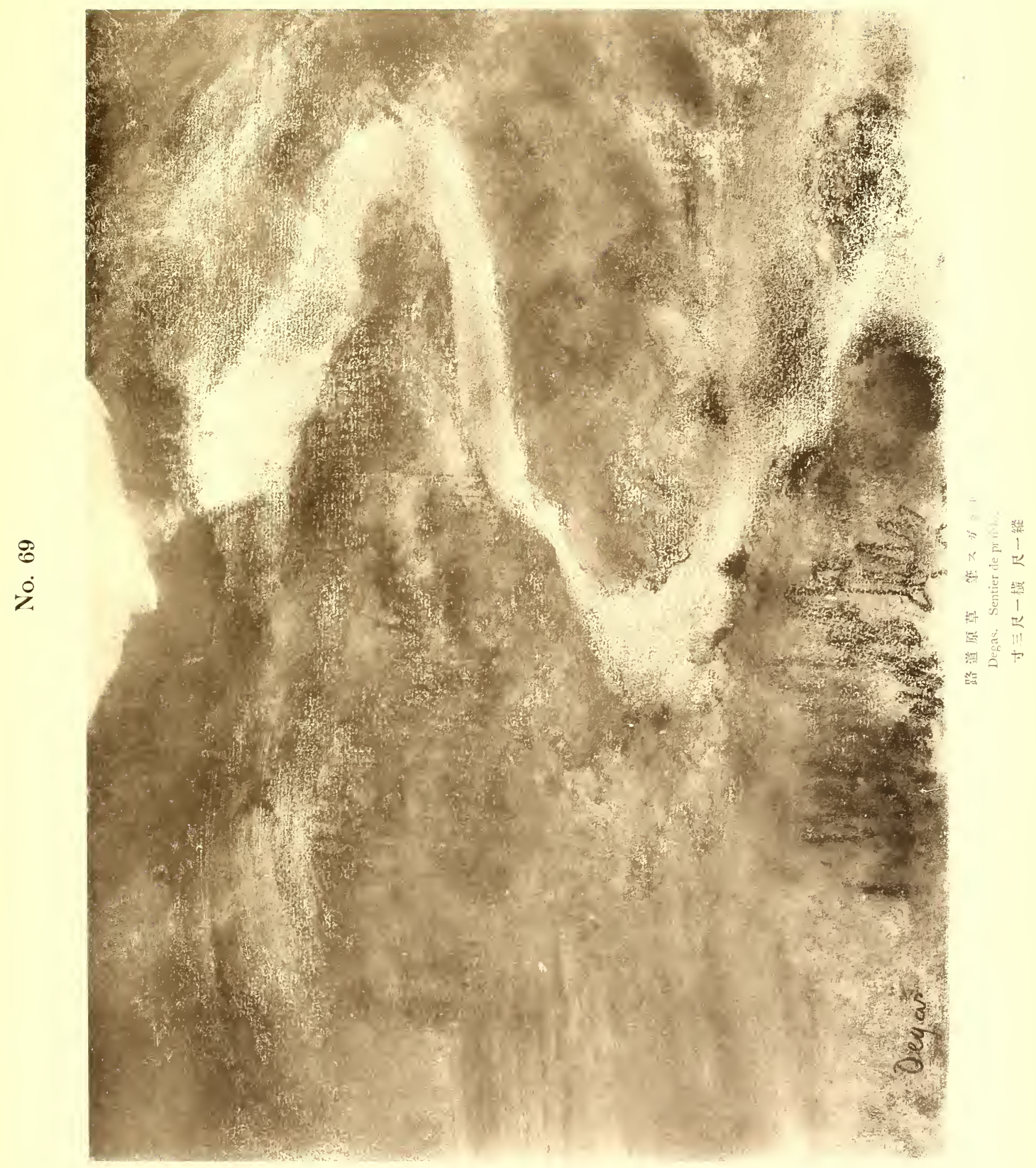


No. 69

\section{HILAIRE GERMAIN EDGAR DEGAS}

FRENCII

1834 -

SENTIER DE PRAIRIE

Pastel

Height, 113/4 inches; length, 151/2 inehes

A straggling path winds upward-its way looking not mlike the reverse course of a swift-descending brookthrough a yellow-golden hillside field bathed in sunshine, and vanishes over the top of the rise in the shadows of a woodland.

Formerly exhibited as a plain "Paysage," apparently, when passing through the hands of Messrs. Durand-Ruei \& Co.; the hillside of the picture does not itself suggest the "meadow" referred to in the newer title.

Signed at the lower left, Degas, 


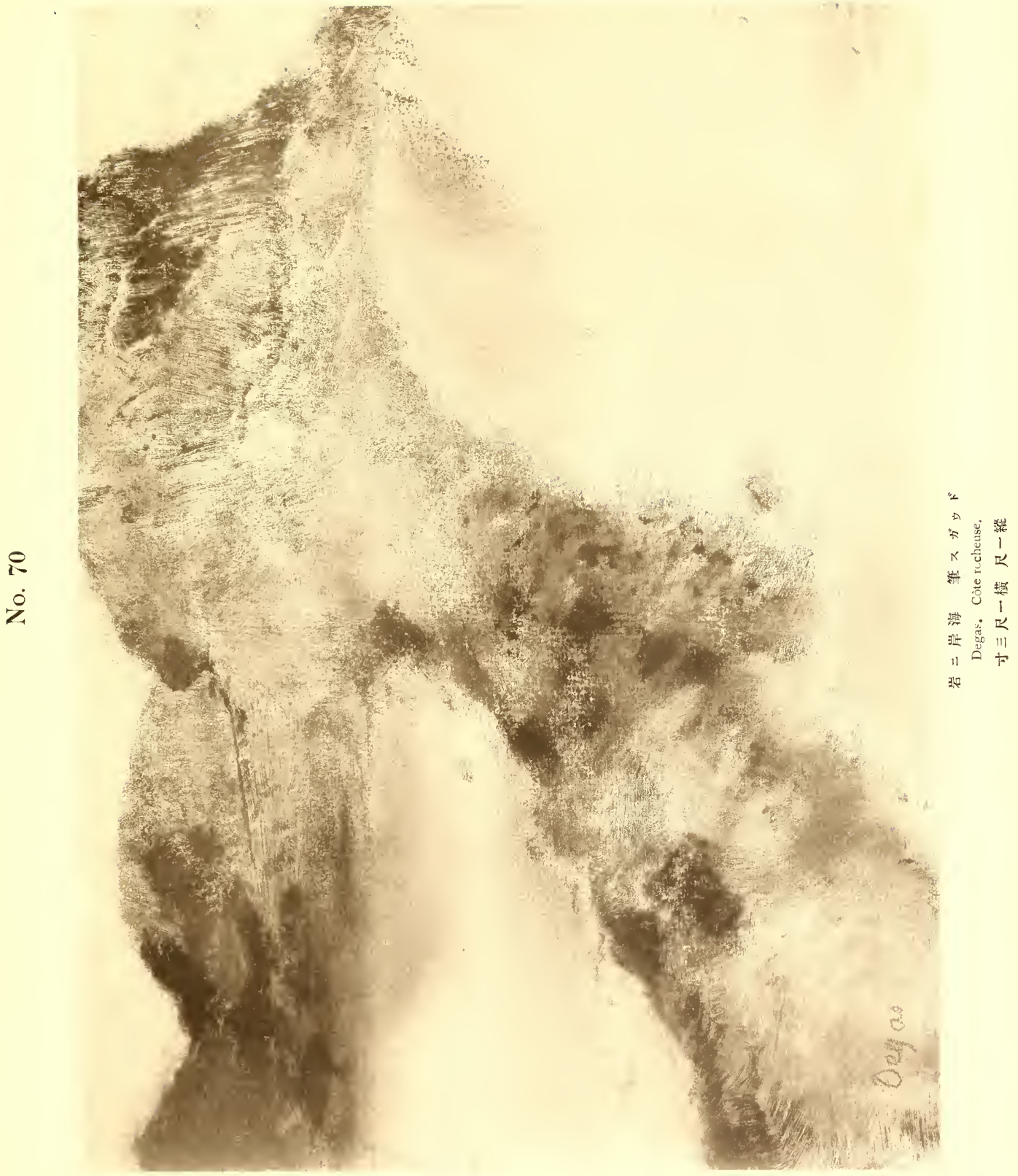




\author{
No, 70 \\ HILAIRE GERMAIN EDGAR DEGAS \\ FRENCH \\ $1834-$ \\ CÔTE ROCHEUSE

$$
\text { Pastel }
$$ \\ Height, 113/4 inches; length, 1.51/2 inches
}

The blue-green sea from right and left runs up on both sides of a low, sandy strip of shore, bearing scant vegetation, leading from the foreground back to a rocky coast. The coast looms grim in its desolation, the gray rocks here yellowed over with iron-rust, there greened with the moisture of the climate-everywhere rugged and weathered.

Signed at the lower left, Degas. 
No. 71

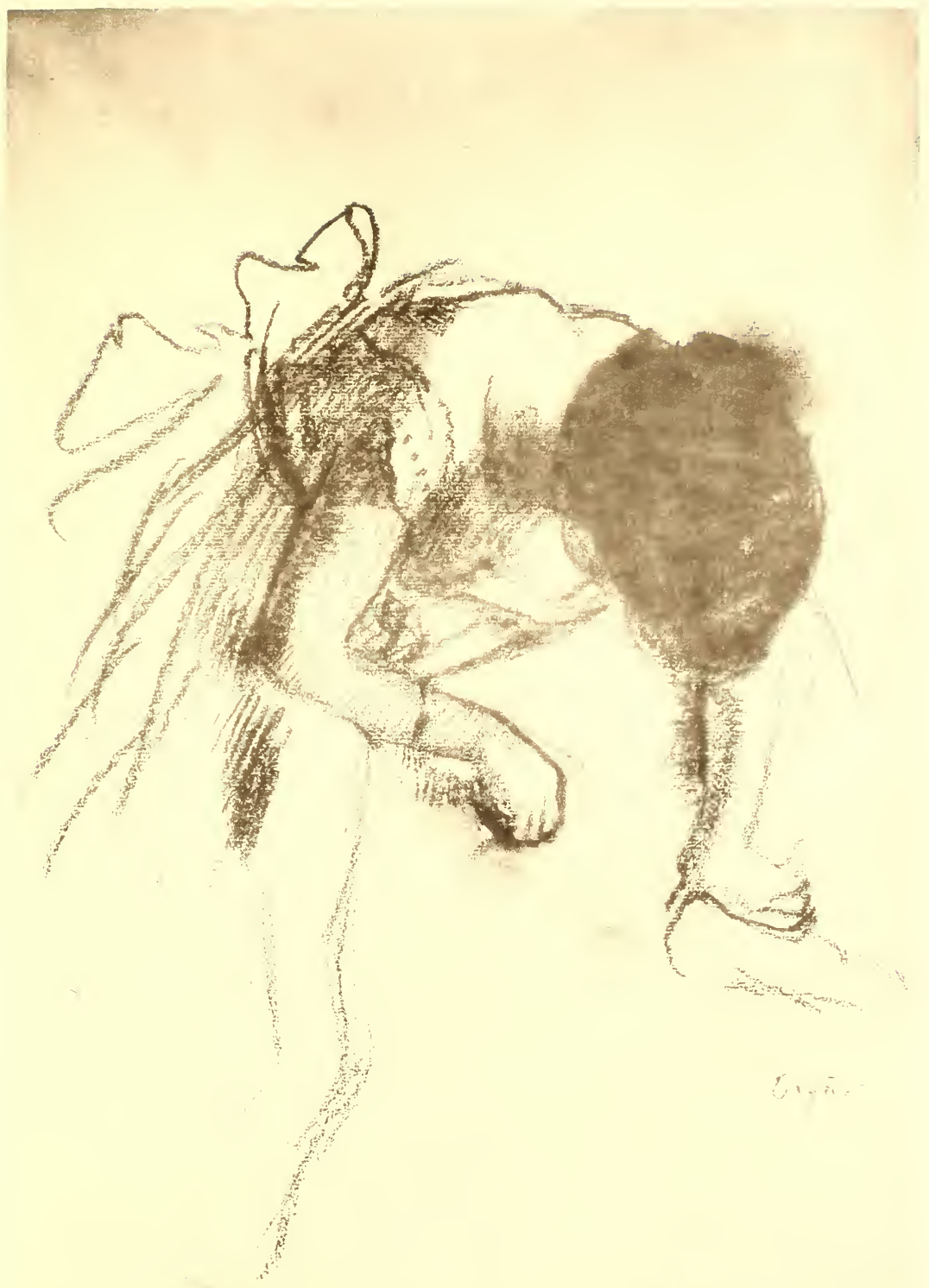

妓魏管スガウト

Degas. Danseuse.

尺一横才五尺一秚 
No. 71

HILAIRE GERMAIN EDGAR DEGAS

FRENCH

$18: 34-$

\section{DANSEUSE}

Pastel

Height, 171/2 inches; width, 113/4 inches

SHe might be called, "The Girl of the Green Hair,"this young woman in ballet costume, leaning over, right elbow on knee, her other hand reaching down to grasp her ankle as if to attend to something there. Her head is bent so far forward that only the top is visible, and her slight, bright green headdress is so rendered that at first there is the illusion of green hair-the complement of some familiar and pronounced reds, of the stage and elsewhere.

Signed at the lower right, Degas. 


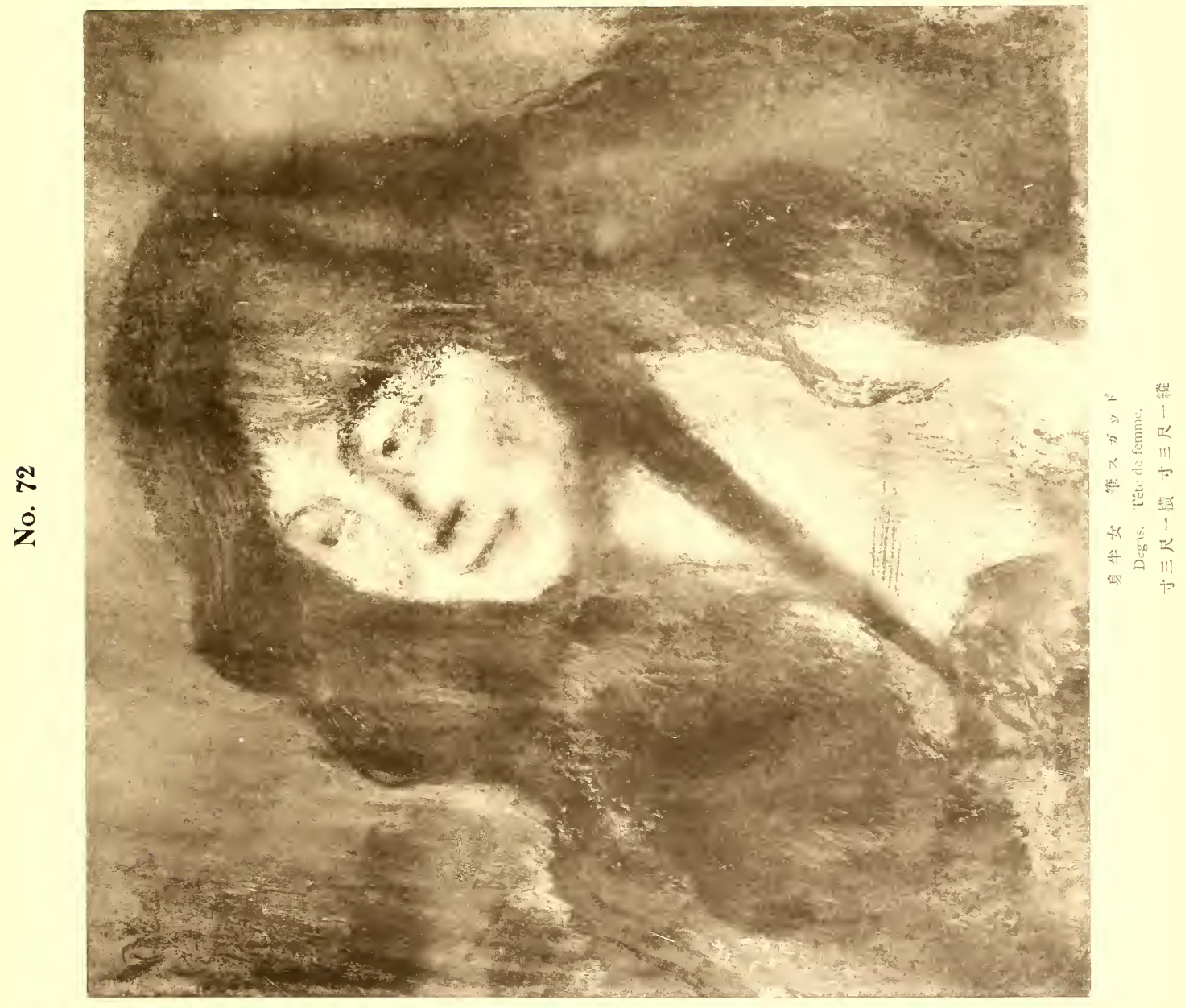


No. 72

\section{HILAIRE GERMAIN EDGAR DEGAS}

FRENCH

$1834-$

TE'TE DE FEMME

Pastel

Height, 151/4 inches; width, 151/4 inches

A Luscious young woman of generous proportions, haloed in the wealth of her brick-red hair, is seen head and shoulders, facing the left, her head cocked coyly over her left shoulder as she glances agreeably toward someone (unseen by the spectator) far to her right. Her right hand, raised from the elbow, is buried in the marvelous hair, and in her left she holds a folded black fan, its upper end poised under her cheek.

Signed at the upper left, Degas. 
No. 73

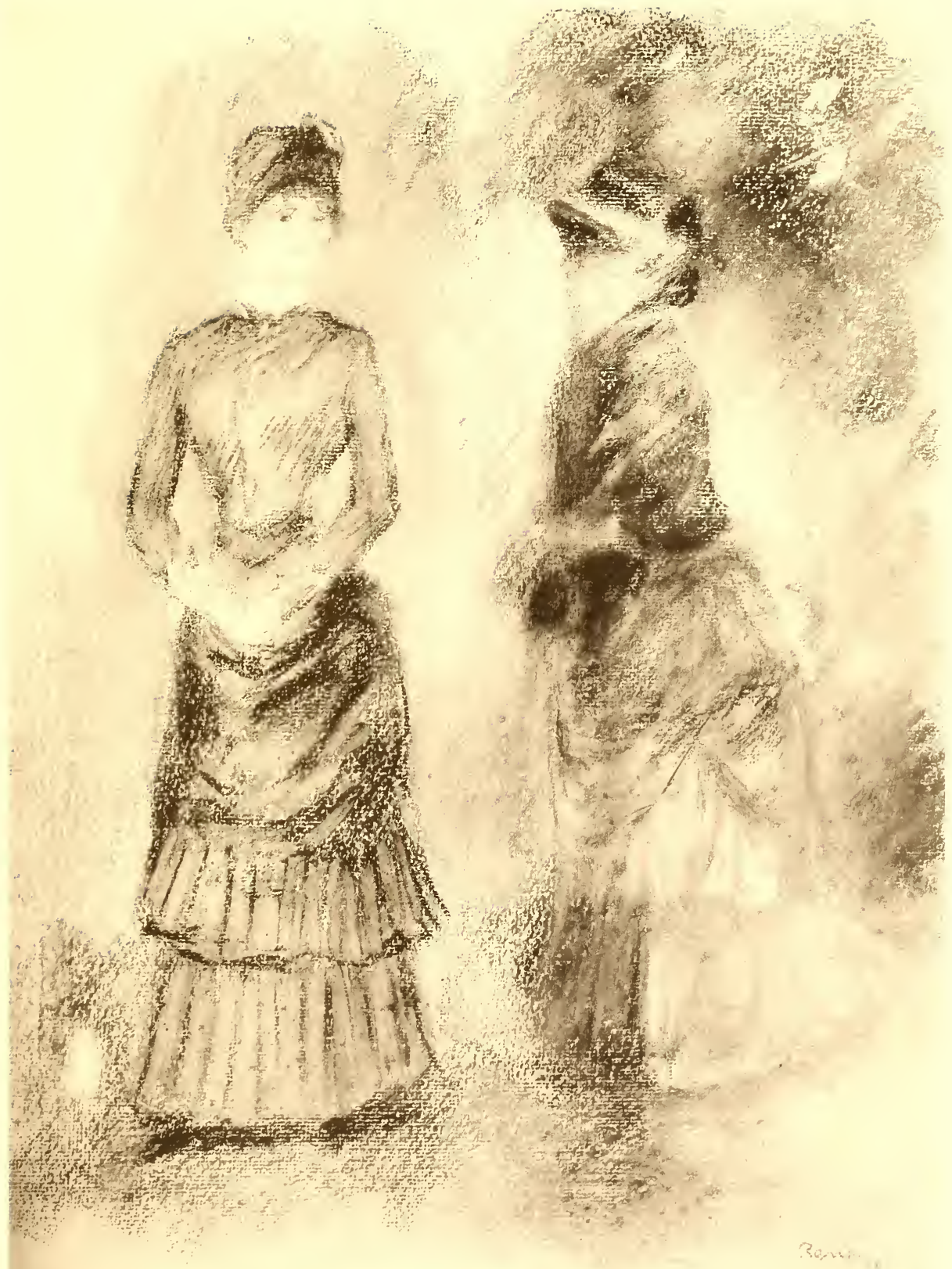

話立女二 等

Renoir. Deux filles.

分五尺一橫分五寸四尺一粉 
No. 73

FIRMIN-AUGUS'TE RENOIR

FRENCH

$18+1-$

DEUX FIILLES

A Sketch in Pastel

Height, 17 inches; width, 121/.2 inches

'Two gIRLs in the dress of some years gone are pictured at full length, standing, or as though about to walk, each independent of the other; one sketched in black against a background of green, and coming in the direction of the spectator, the other in red and blue with a smudged and effectively varied background. She in red is seen in profile. Her sister's face is of a type of ten seen in France.

Signed at the lower right, Renoir. 


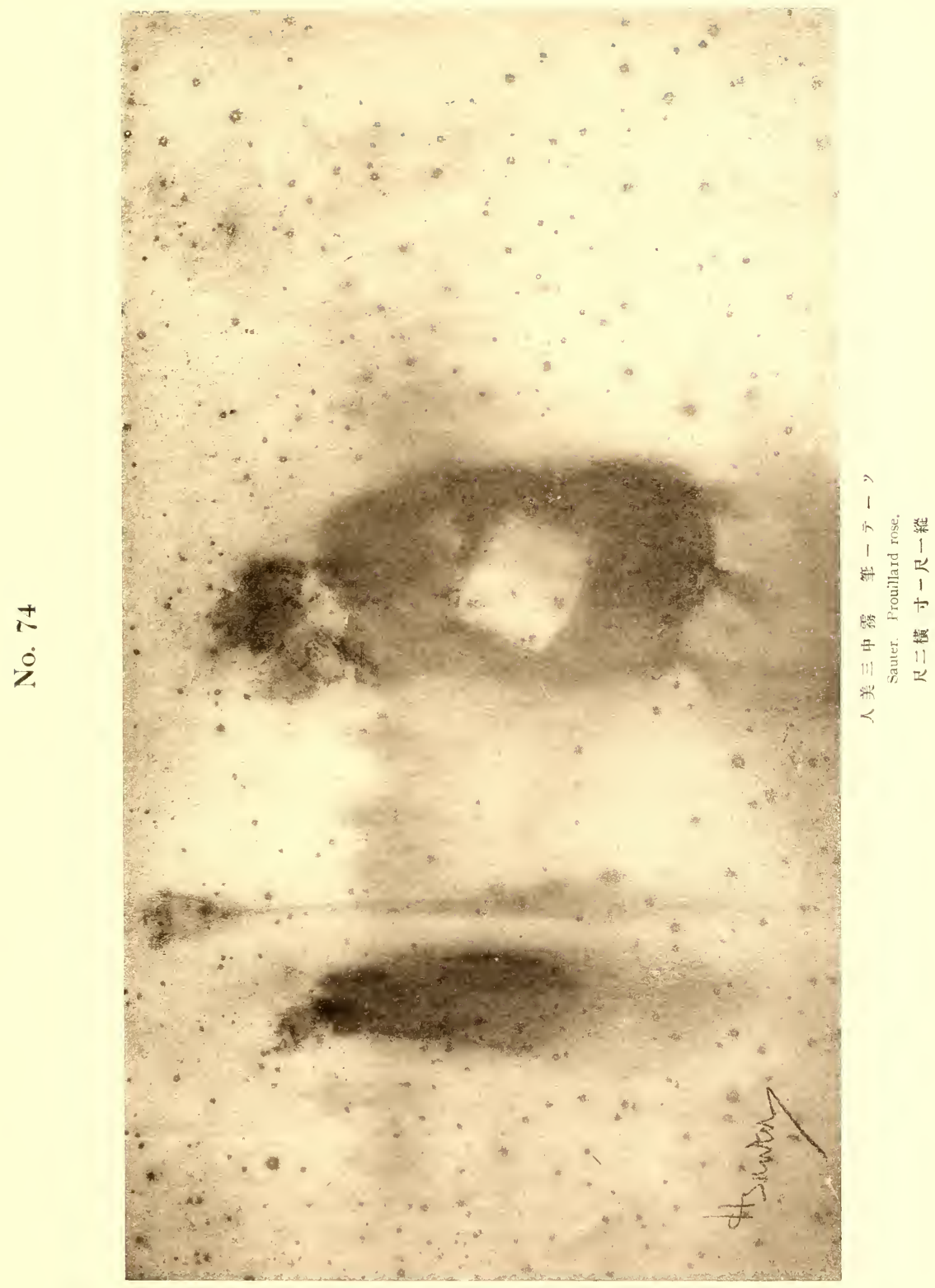


No. 74

\section{SAU'TER}

\section{LE BROLILLARD ROSE}

$$
\text { Pastel }
$$

$$
\text { Height, } 13 \text { inches; length, 231/2 inches }
$$

ONE of the thick Paris fogs, which sometimes cause apprehensive shopkeepers to haul down their iron shutters lest the apaches close in from the exterior boulevards, has settled over a broad street, obscuring buildings, kiosques and lamp posts, the whole vaporous mist dimly tinged in a sort of pinkish glow. In the foreground a chic little milliner in black waist and brown skirt, making her way with a female companion along the sidewalk, looks enquiringly ahead.

Signed at the lower left, H. Sauter. 
No. 75

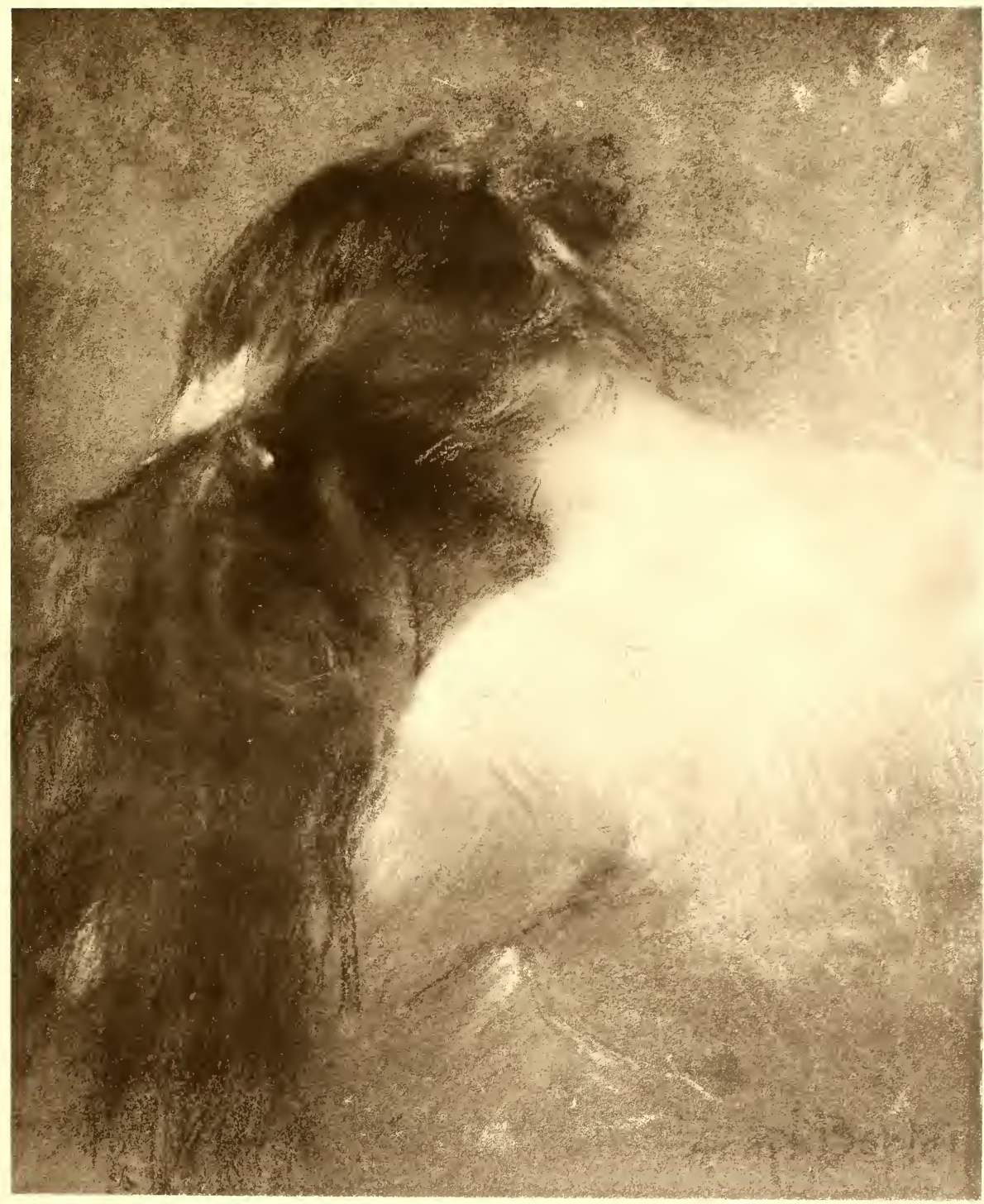

女結戀篗ントルパ

Barton. Dame se coiffant.

分五寸二尺一橫 寸五尺一称 
No. 75

\section{ARMAND BER'TON}

FRENCH

1854 -

DAME SE COIFW INT

$$
\text { Pastel }
$$

Height, $171 / 2$ inches; width, $141 / 2$ inches

'I'HE half-length figure of a young woman seen from the back as she dresses her reddish-yellow locks. With her left hand the sitter has gathered her tresses into a bunch at the base of her head, and they flow over her arm, revealing the upper back and neck as she turns her head toward the right. She wears a blue underwaist, low at the neck, where the flesh tones, between the blue of the waist and the reddish hair, and the graceful curve of body as the head is turned away to the right, have caught the artist's fancy. Signed at the lower right, Armd. Berton. 
No. 76

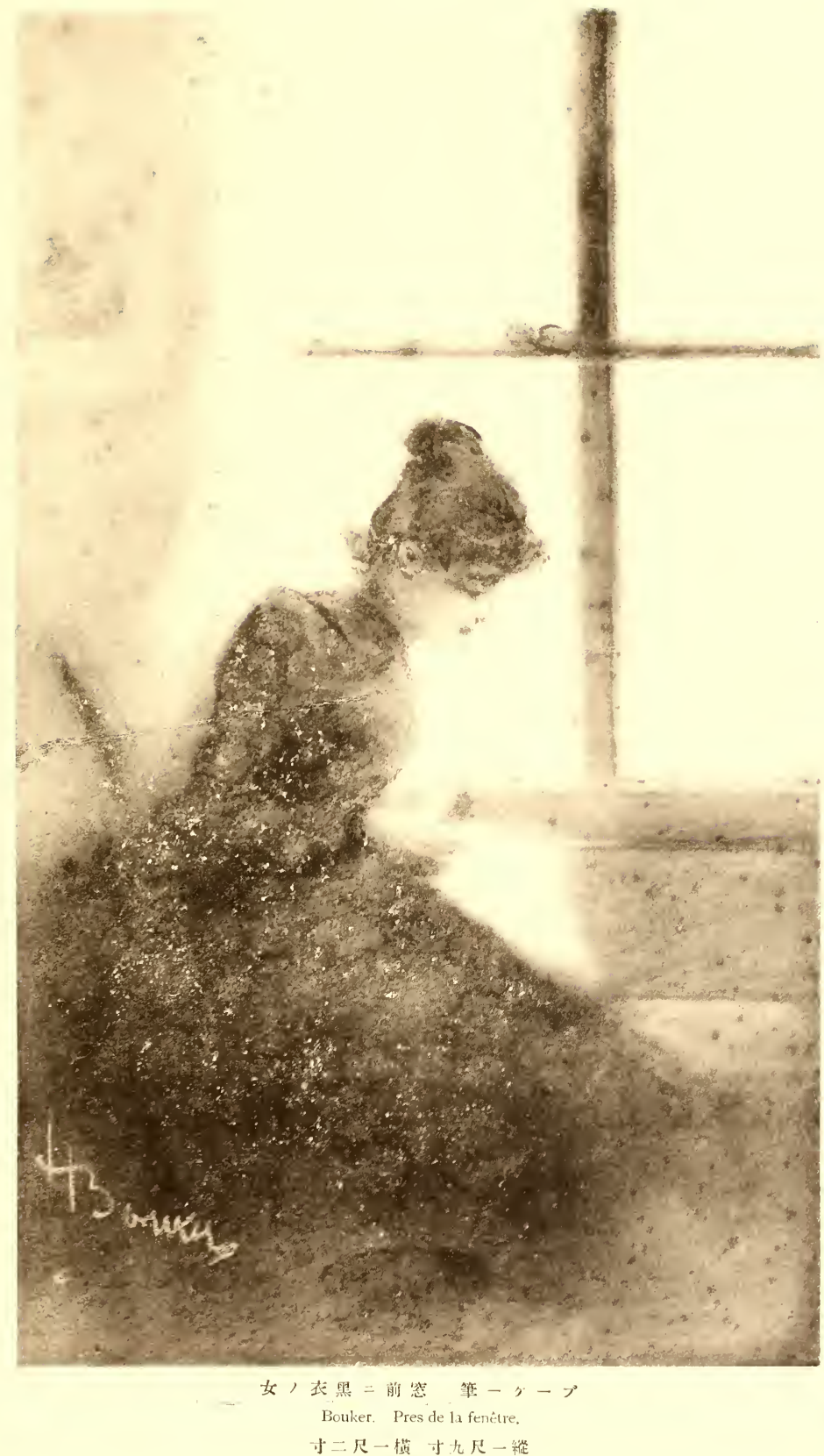


No. 76

\title{
H. BOUKER
}

\section{PRESS DE LA FENETTRE}

\author{
Pastel
}

Height, $2 \mathcal{2}$ inches; width, $1+$ inches

A young lady of pleasant features and slightly tip-titled nose is seated at a window in the winter time, sewing or embroidering on some white material gathered in her lap. She is dressed in dark color's and the room itself is dark except at the window, so that she appears almost in silhouette as it were. 'Through the window panes are seen outlined the bare branches of a tree.

Signed at the lower left, H. Boulier. 
No. 77

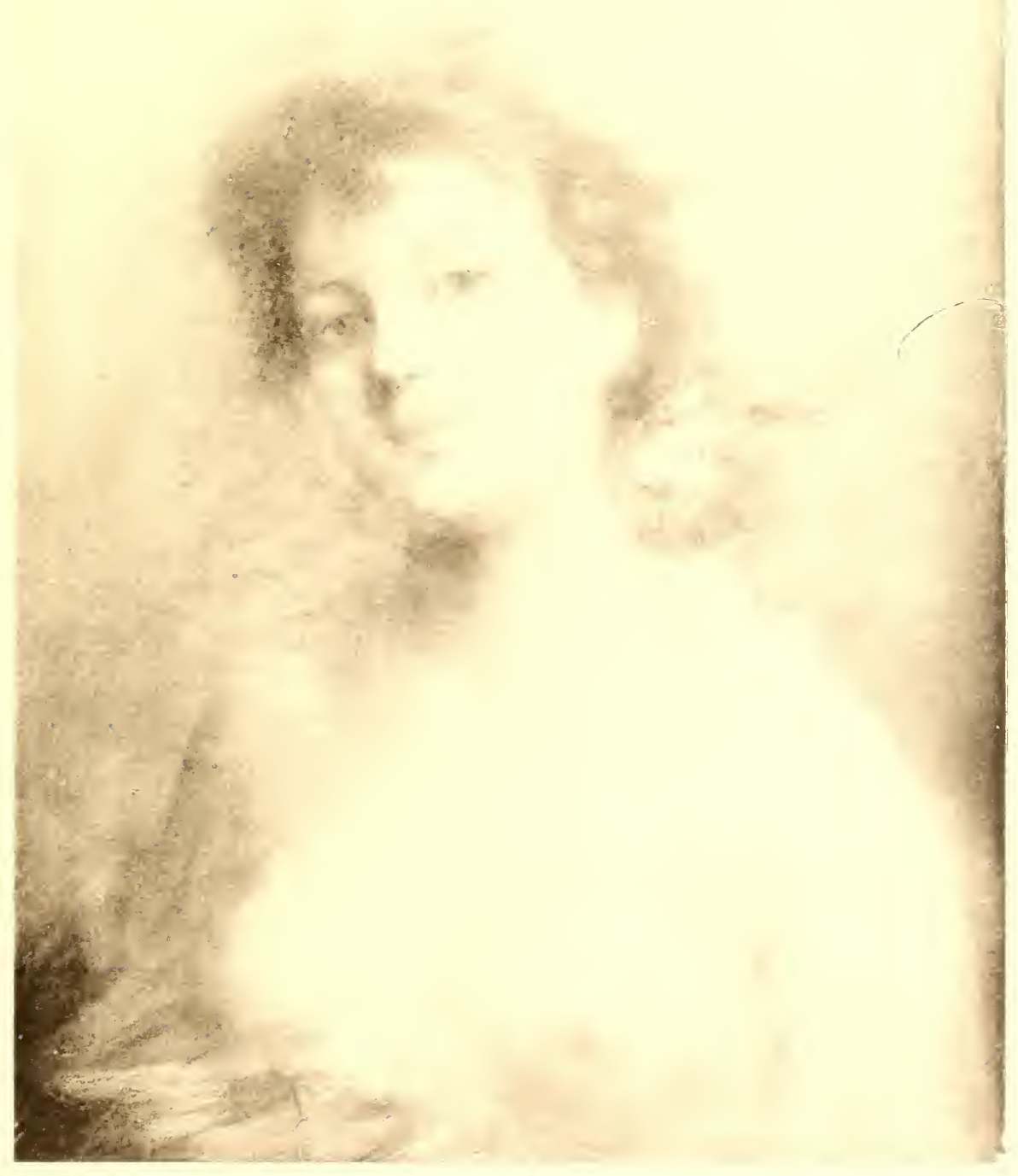

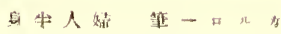

Callor. Dame.
尺一㯼市七尺一維 
No. 77

\section{GEORGES CALLO'T}

FRENCH

Nineteenth Century

DAME

$$
\text { Pastel }
$$

Height, 201/4 inches; width, 15\%/4 inches

A young woman with light brown hair, her head poised over her right shoulder, glances smilingly in the direction of the spectator, with some pale yellow or tea roses that have decked her hair falling about her neck. She is seen head and bust, a single blue wrap that has dropped from her shoulders clasped with one hand below the exposed breasts.

Signed at the upper right, Georges Callot. 
No. 78

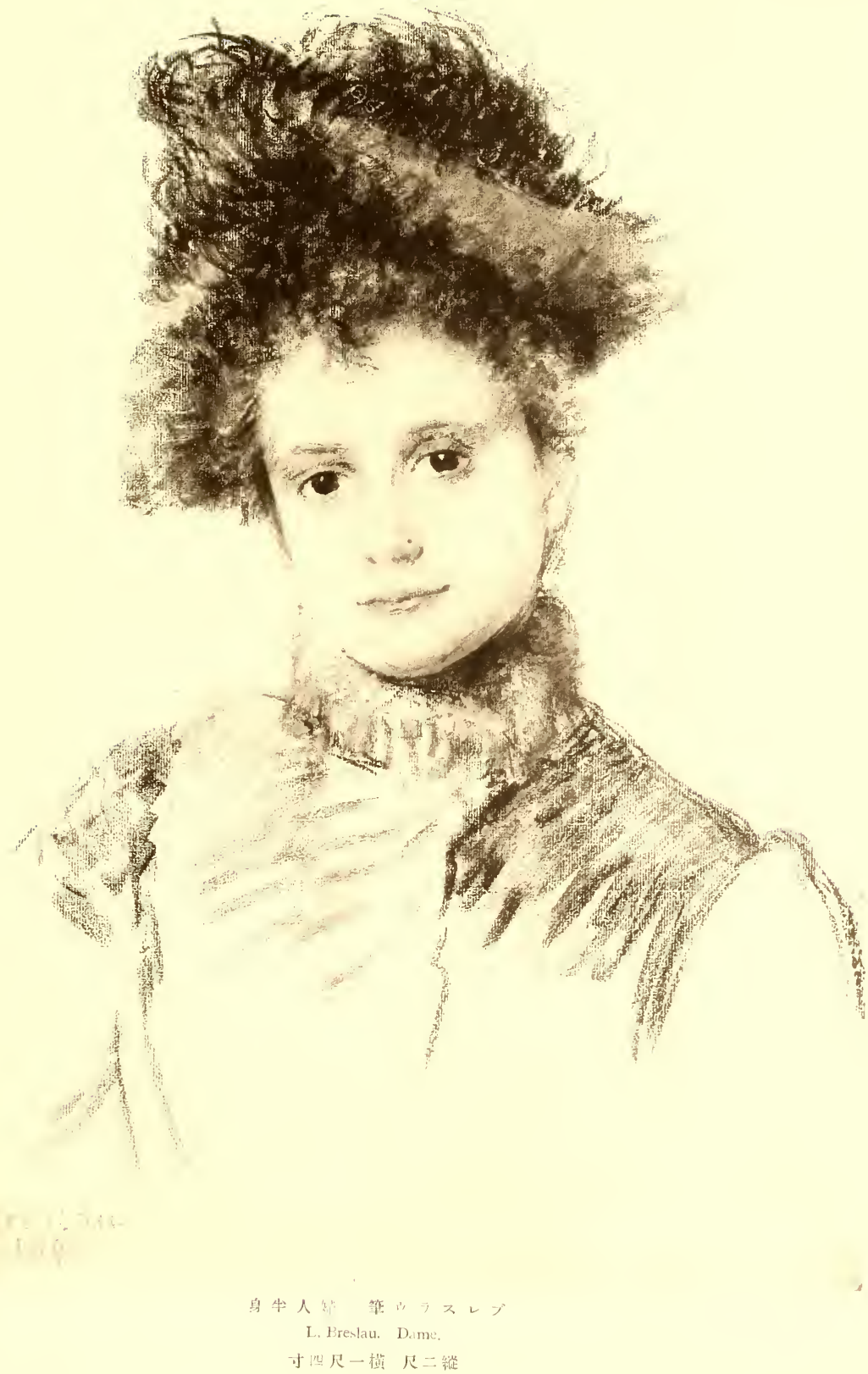




\section{No. 78 \\ LOUISE BRESLAU}

GERMAN

$1856-$

$D A M E$

$$
\text { Pastel }
$$

Height, 231\%2 inches; width, 161\% inches

THE artist has drawn the portrait, in head and shoulders, of a lady with clear hazel eyes whose features have the suggestion of a smile, though in repose, and who looks straight at the spectator, her head slightly tilted toward her right shoulder. She is dressed for the street, her jacket buttoned to the neck, and her lips are a vivid pink.

Signed at the lower left, L. Breslau, 1891. 


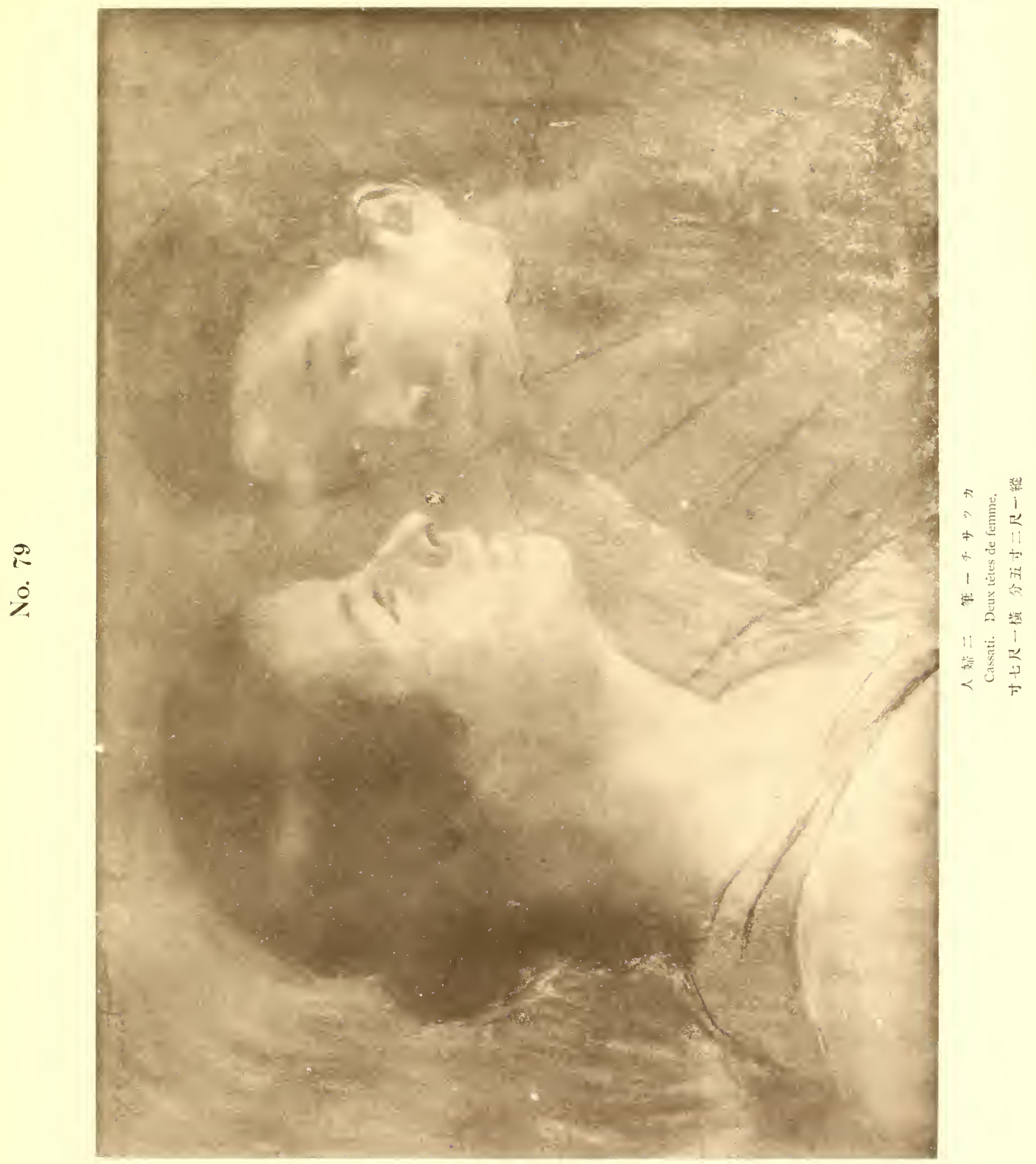


No. 79

\section{MARY CASSAT'T}

AMERICAN

Contemporary

\section{DELX TETES DE FEMME}

$$
\text { Pastel }
$$

Height, 15 inehes; length, 21 inches

Two young women, both self-contained and moderately aggressive, wise each in her own beilef and way, are depicted, head and shoulders, as in a temporary pause in a conversation or an argument. One, with plump outlines and deep russet-brown hair, whose light green and pink house gown can be seen on her shoulders, is figured in profile facing to the right. Her interlocutor (all but her head screened by a red fan which she carries), is darkhaired and dark-eyed, and looks at her plump companion searchingly and questioningly.

Signed at the "pper left, Mary Cassatt. 


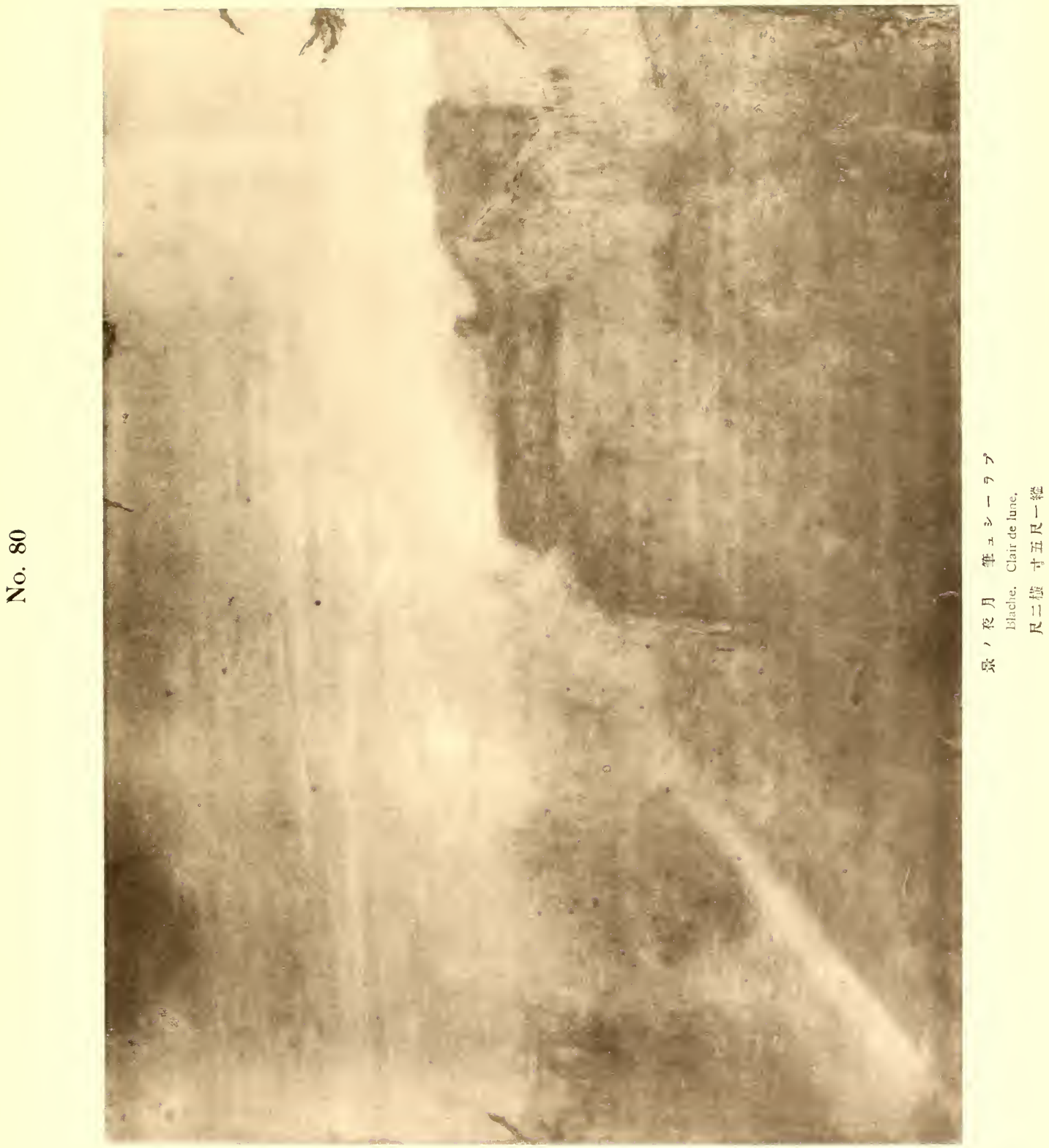


No. 80

\section{PHILIPPE CHARLES BLACHE}

\section{FRENCH}

Deceased

\section{CLAIR DE LUNE}

$$
\text { Pastel }
$$

Height, 18 inches; length, 23\%/4 inches

Is the greenish, blue and gray mists of moonlight, a landscape of hills and valley appears as if in the process of creation and still coming into being. In the foreground a group of dwellings is well defined, and back of them trees are beginning to assert themselves, but in concilliatory aspect, while beyond, over the distant hills, the moon is just appearing, and leaves their outlines vague against a still somber and o'erclouded sky.

Signed at the lower right, dated 1882 and 188\%, and numbered 
No. 81

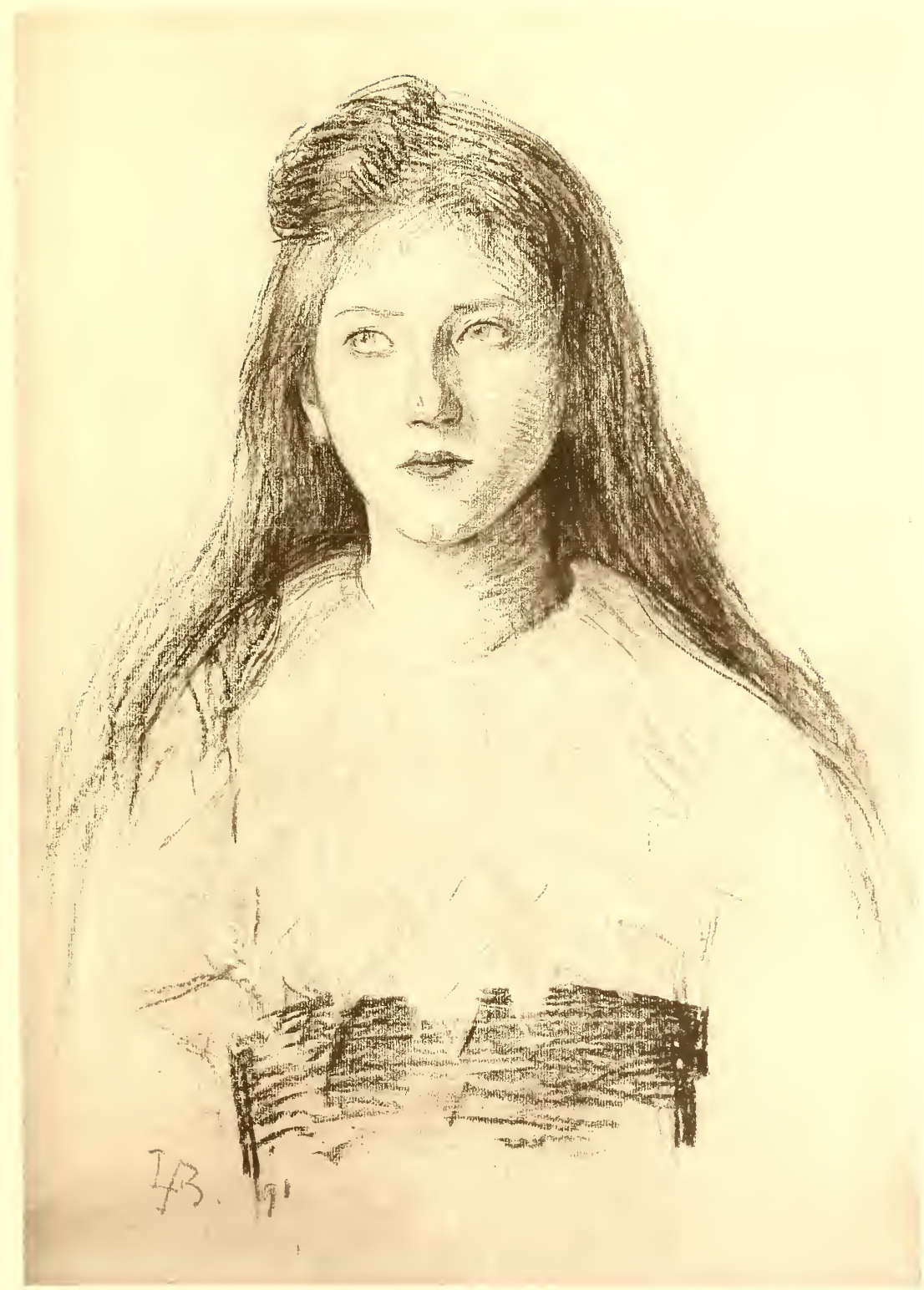

身牛女處䇠ウラスレブ

L. Brelau. Jeune fille.

寸四尺一横 尺二縰 
No. 81

\section{LOUISE BRESLAU}

GERMAN

$1856-$

JEUNE FILILE

$$
\text { Pastel }
$$

Height, 24 inches; width, 163/4 inches

A young girl of quiet and thoughtful expression is seen at half-length, standing, facing the spectator, and looking intently to her right. Her brown hair is falling over her shoulders, which are covered by the over-folding longpointed collar of her white and lavender gown. Just below the front of the low-hanging collar a wide black sash binds her high waist.

Signed at the lower left, L. B. (in a monogram), '91. 
No. 82

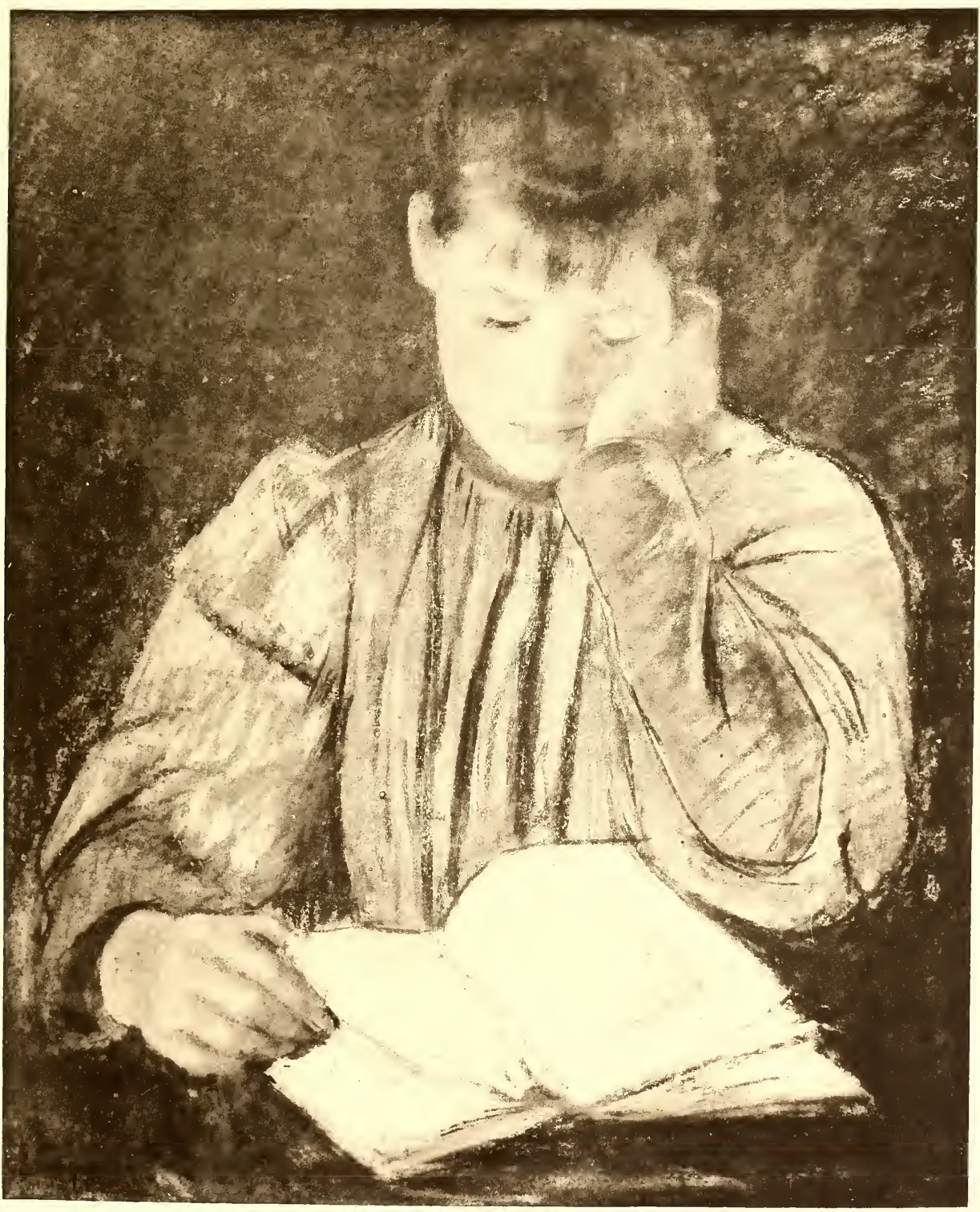

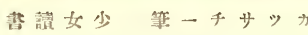

分五可四尺一椯分五可七尺一維 
No. 82

\section{MARY CASSAT'T}

AMIERICAN

Contemporary

\section{JEUNE FILLE LISANT}

\section{Pastel}

Height, 213/4 inches; width, 171/2 inches

SEATEd at a table facing the spectator a young girl is reading a book which lies open in front of her. Her flaxen hair is banged over her forehead and brushed straight but loosely back over her crown. She leans with one elbow on the table, resting her cheek on the hand, and with the other hand fingers the leaves of her book. Her features are clearly marked and her cheeks are almost as pink as the lower sleeves of her blue frock. She is shown against a neutral background.

Signed at the lower left, Mary Cassatt. 

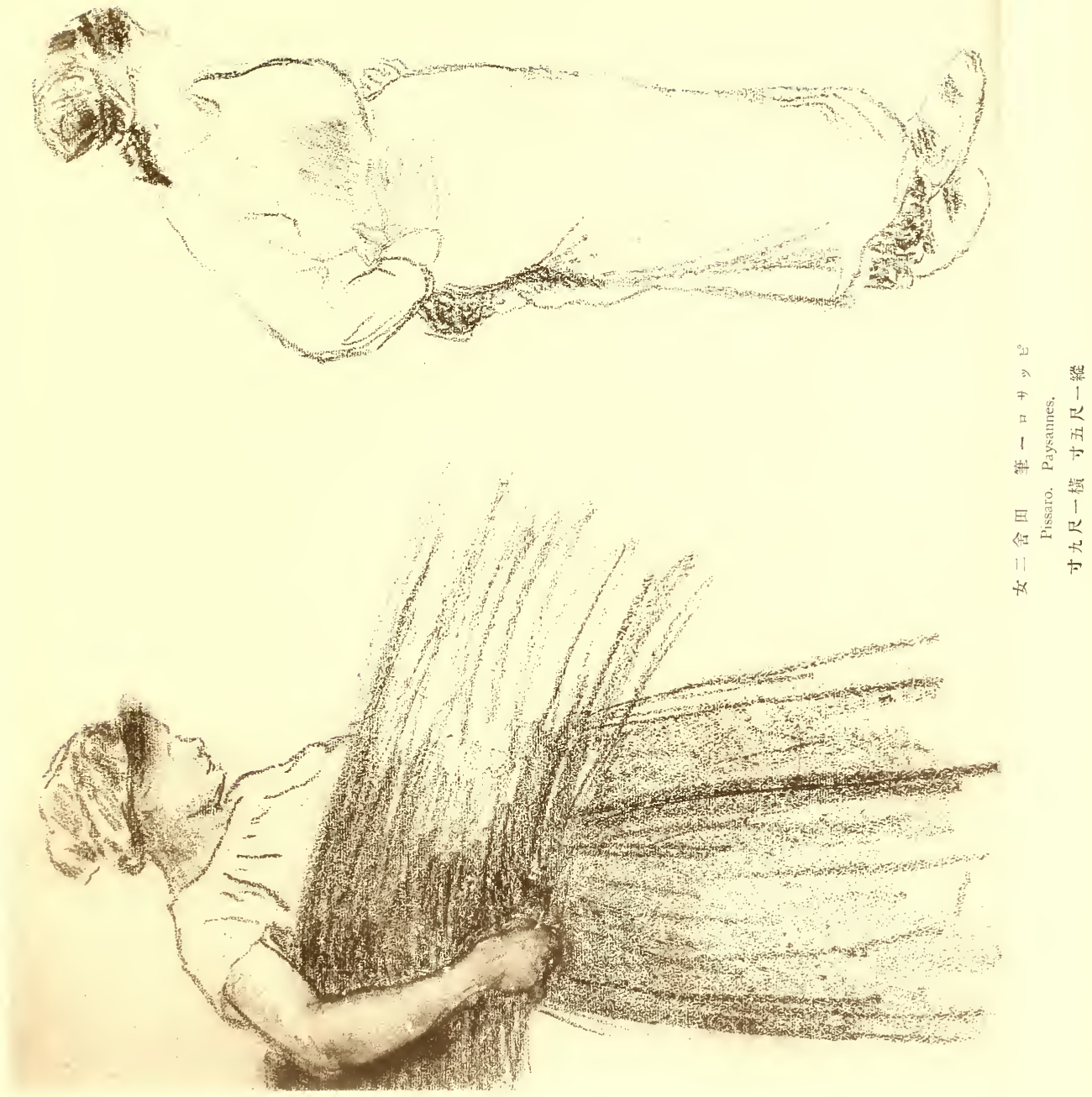
No. 83

\section{CAMILLE PISSARRO \\ FRENCH}

1810-1903

\section{PAYSANNES}

$$
\text { Pastel }
$$

Height, 18 inches; lcngth, 221/2 inches

Two sTURDy peasant women are pictured in characteristic attitudes and with much homely attraction. One, with her arms bare to the elbow, stands,- head bent downward, as ever,-holding under one able arm a bundle of sheaves at her waist. She wears a gray blouse and an old-pink skirt. 'The other woman-somewhat younger but with heavy features and vacuous expression - clad in blue, with a red and yellow headdress, stands carelessly by, with her heavy hands resting on her wide hips.

signed at the lower right, C. P. 
No. 84

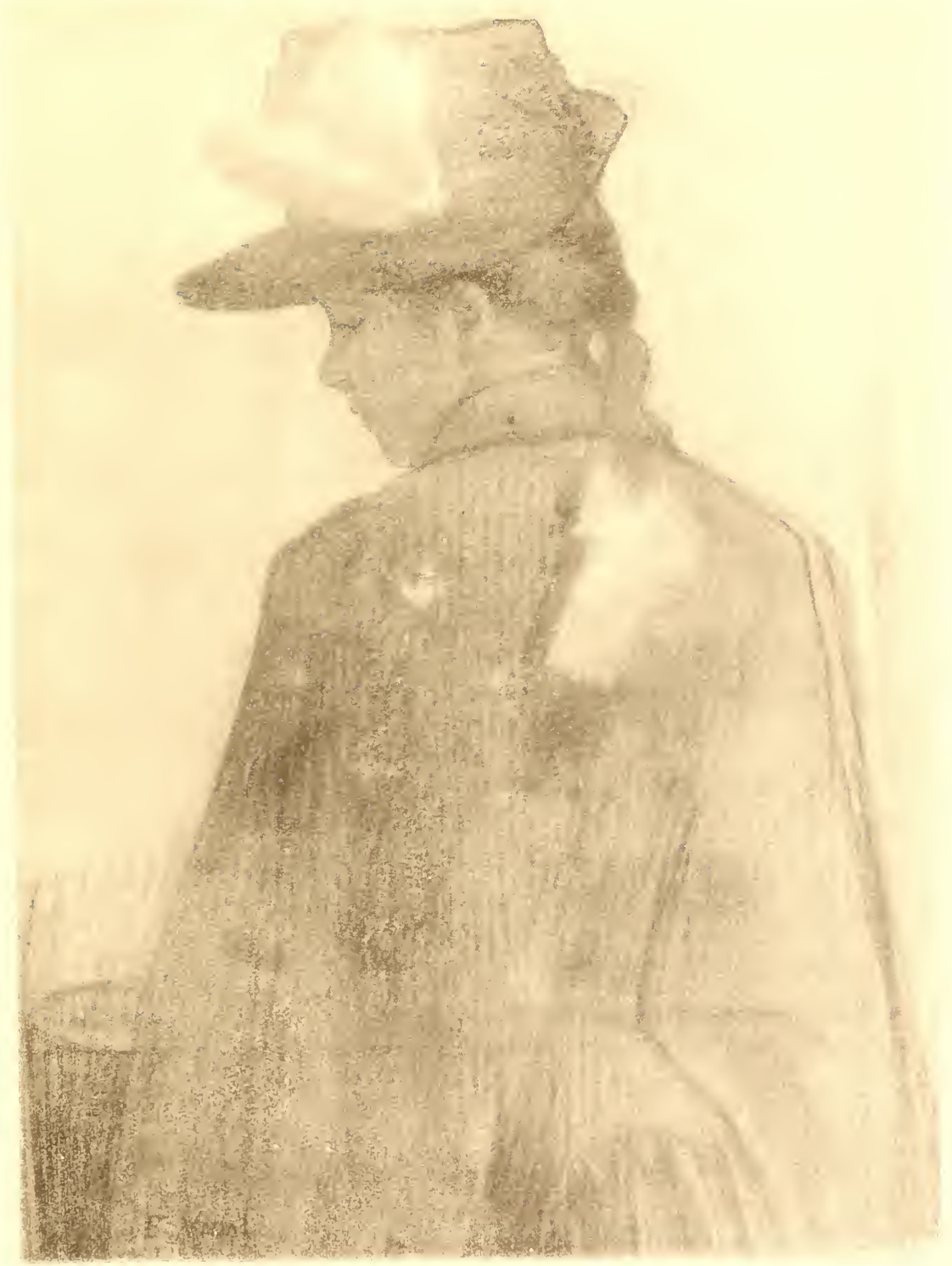

婪後女虑策儿一名小

Vidal. Jenne fille.

才五尺一横尺二筑 
No. 84

\section{EUGENE VIDAL}

FRENCH

Nineteenth Century

JEUNE FILLE

$$
\text { Pastel }
$$

Height, 231/2 inches; width, 173/4 inches

A TRIM young girl in street attire is shown at threequarter length, back view, her head turned to the left so that her face is seen in profile over her shoulder. She has regular features and looks steadily at something below her at her side. Done throughout in neutral tones.

Signed at the lower left, E. Vidal. 
No. 85

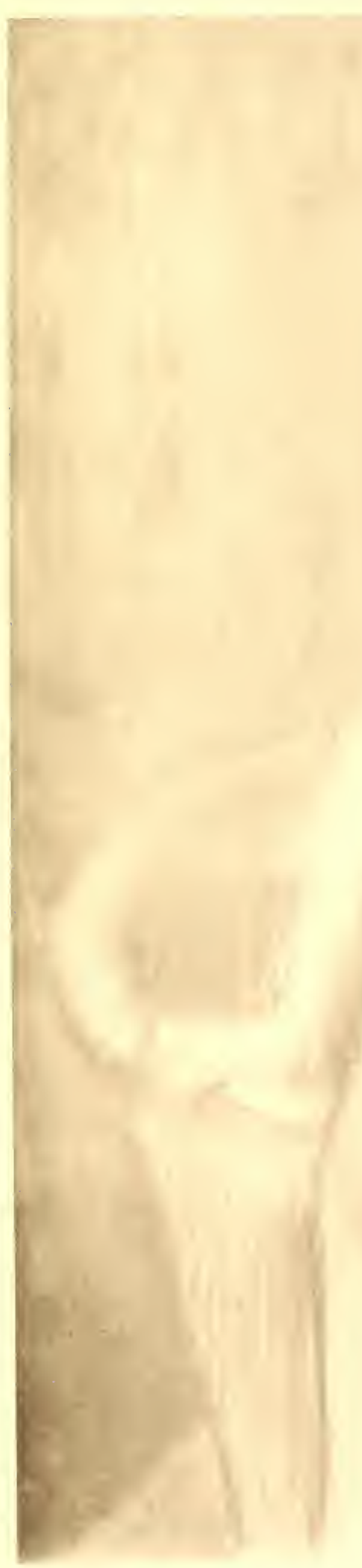

$$
\begin{aligned}
& \text { Degas. Paigntu`e. } \\
& \text { 虎ル入二晹女不片に }
\end{aligned}
$$


No. 8.5

HILAIRE GERMAIN EDGAR DEGAS

FRENCH

1834-

BAIGNEUSE

$$
\text { Pastel }
$$

Height, 21 inches; width, 171/2 inehes

Ix a room with warm-hued walls of a yellowish tone, a young woman of ample figure is climbing into a bath tub, which reflects blue and purple lights save where a white towel is thrown over its rim. The varied lights and their reflections on the nude flesh of the bather's back and side, which are toward the spectator, have made an interesting study together with the drawing of the flexuous pose.

Signed at the upper left, Degas. 
No. 86

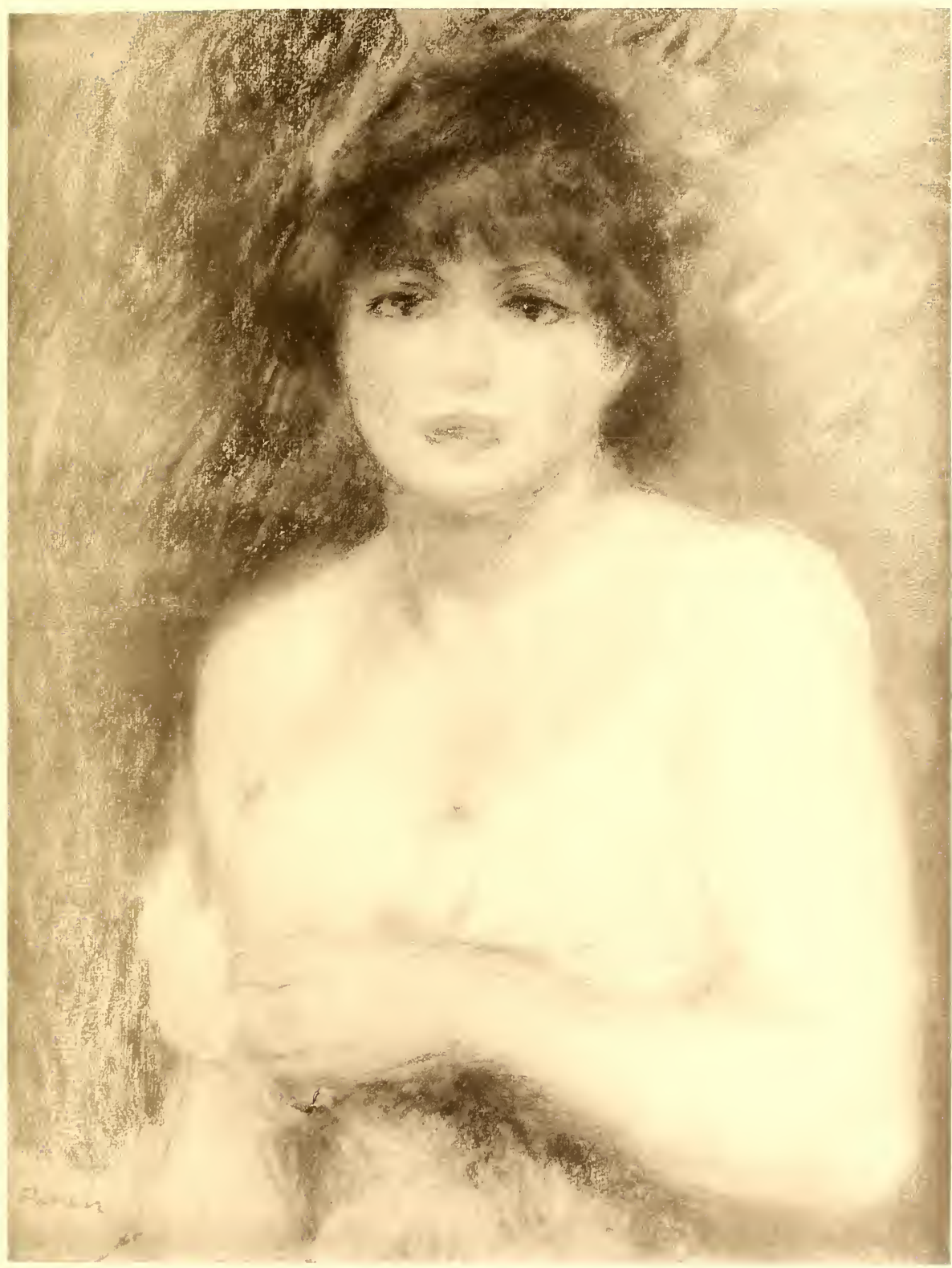

身牛女管ルーアノル

Renoir. Femme, de ni-nue

寸六尺一橫 尺二榓 
No. 86

\section{FIRMIN-ALGUSTE RENOIR}

FRENCH

$18+1-$

HEMME DEMI-NUE

Pastel

Height, $931 \%$ inches; width, 1734 inches

A young woman with sapphire-blue eyes and light brown hair is seen at half-length, and looking directly at the spectator, her lips parted. Her single, bluish-white, filmy undergarment has slipped from one shoulder below the well rounded bust, and the painter has studied the tones and mottlings of the neck, breast and arms.

Signed at the lower lett, Renoir. 
No. 87

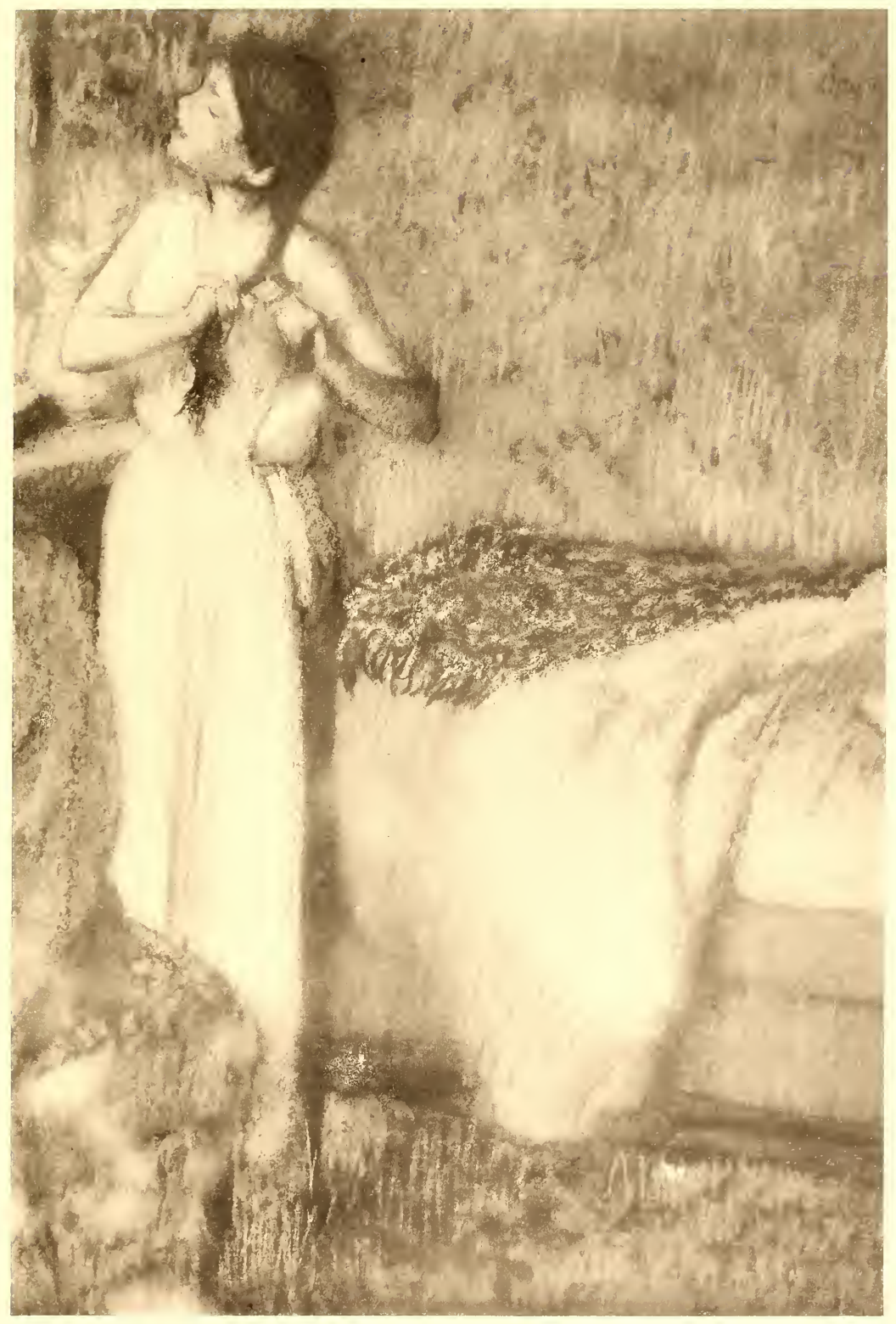

Degas, Toilette matinale.

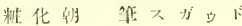


No. 87

\section{HILAIRE GERNAIN EDGAR DEGAS}

FRENCH

$1834-$

\section{TOILETTE MATINALE}

$$
\text { Pastel }
$$

Height, $231 / 2$ inches; width, $171 / 2$ inches

A young woman has arisen from bed and stands, partly dressed, braiding her yellowish-brown hair, at a washstand that holds a blue bowl and pitcher. Her figure is slim, and as she turns her head sidewise and tilts it back for convenience at her braiding, her still sleepy face is seen in profile.

Signed at the upper right, Degas, '94. 


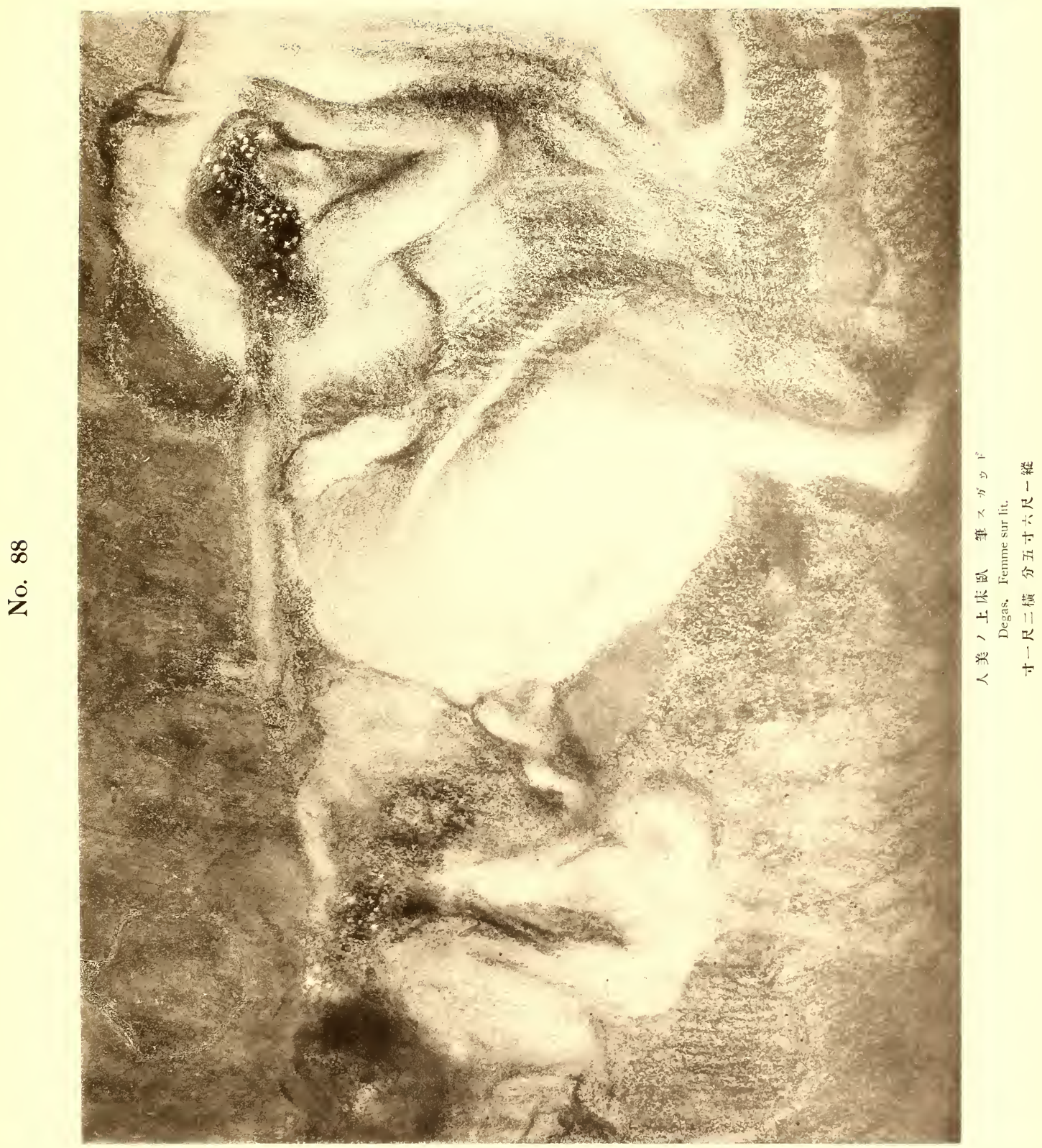


No. 88

\title{
HILAIRE GERNAIN EDGAR DEGAS
}

\author{
FRENCH
}

1834-

FEMME SUR LIT

Pastel

Height, 193/4 inches; length, 251\%2 inches

A WEARY young woman in a negligée garment-quite likely a tired model, resting--lias rolled the wrap down from her shoulders and thrown herself carelessly forward upon a divan, one knee curled under her, one foot resting on the floor,--lier torse among the pillows, her red-brown hair falling over her back. Her face, turned three-quarters front, lies against her right hand upon the pillow. The other arm is extended backward along the back of the sofa, and vari-colored draperies are scattered about. Signed at the lower left, Degas. 
No. 89

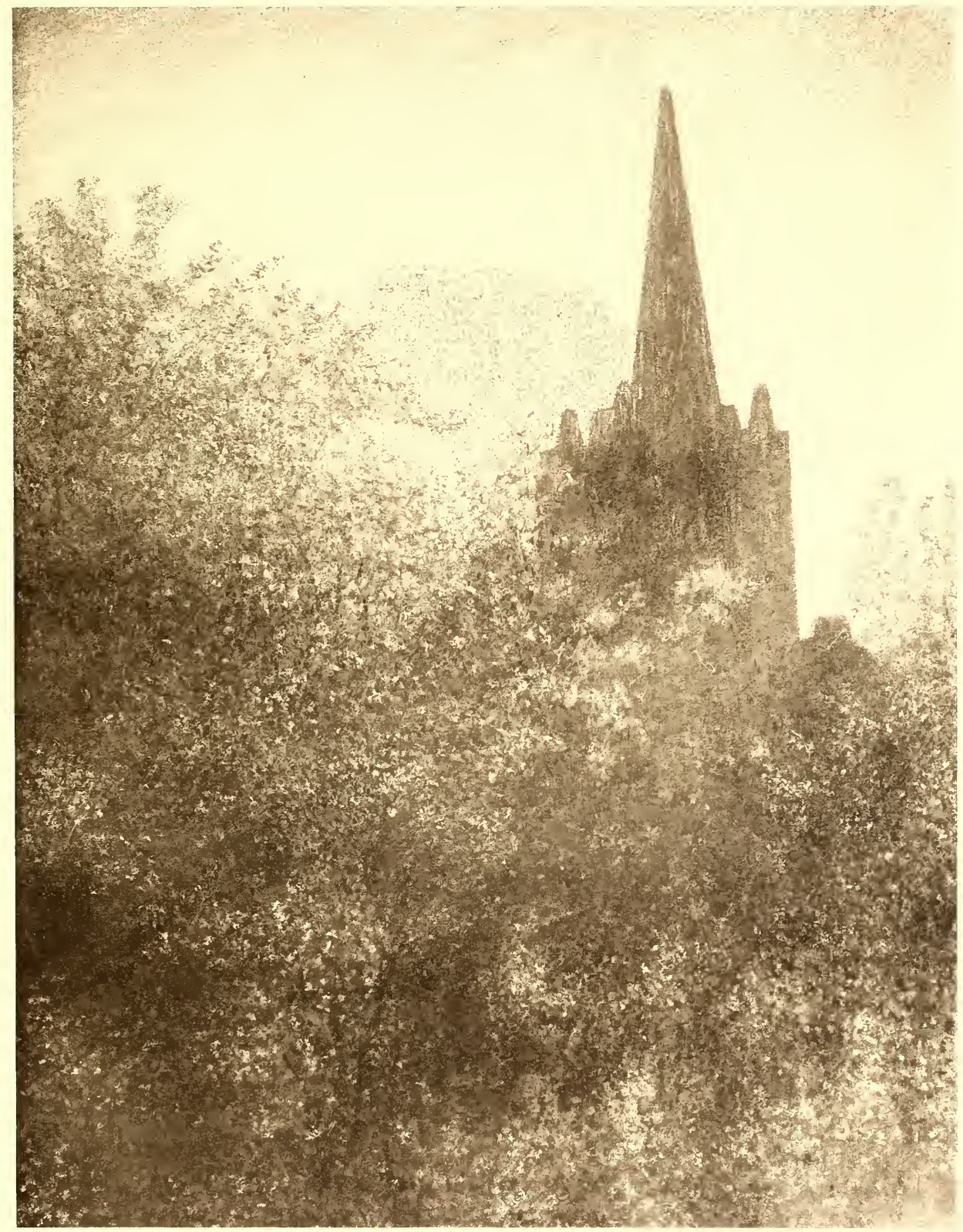
花, 秦篗コシーラブ
Blache, Printemps.

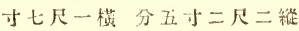


No. 89

PHILIPPE CHARLES BLACHE FRENCH

Deceased

PRINTEMPS

$$
\text { Pastel }
$$

Height, 261\%2 inehes; width, 201/2 inches

Springtime in Isère, in the southeast of France, with the Grenoble spire which Blache found so interesting as the principal architectural feature of the composition. This old clock tower of Grenoble is one that the artist studied many times, rendering it, as he says on the back of this picture, from month to month of the year, in the varying weather, sometimes depicting also the mount behind it, known locally as "Nero's Helmet," which is visible when the weather conditions are favorable.* ('The French text of the inscription on the back appears hereunder.) Here the spire is already in the evening shadows - the month is March-although the curious mountain beyond it is still alight with the sun's late rays aloft, and the sky is yet light and blue, with tinges of sunset. Alow, on every hand, the church tower below the spire is embraced in masses of blossoms, which seem strange of hue in the evening light, and mount to the very topmost twigs of the tall trees.

Signed at the lower left, dated 1894 and 1897 , and numbered 49 .

**Variations selon les mois de l'année. . . et le temps qu'il fait sur ce motif: 'Un vieux clocher de Grenoble-avec-derrièrevisible parfois . . . selon le temps .. . le mont qu'on appelle la-bas "Casque de Néron.", Ceci est un soir de Mars." 
No. 90

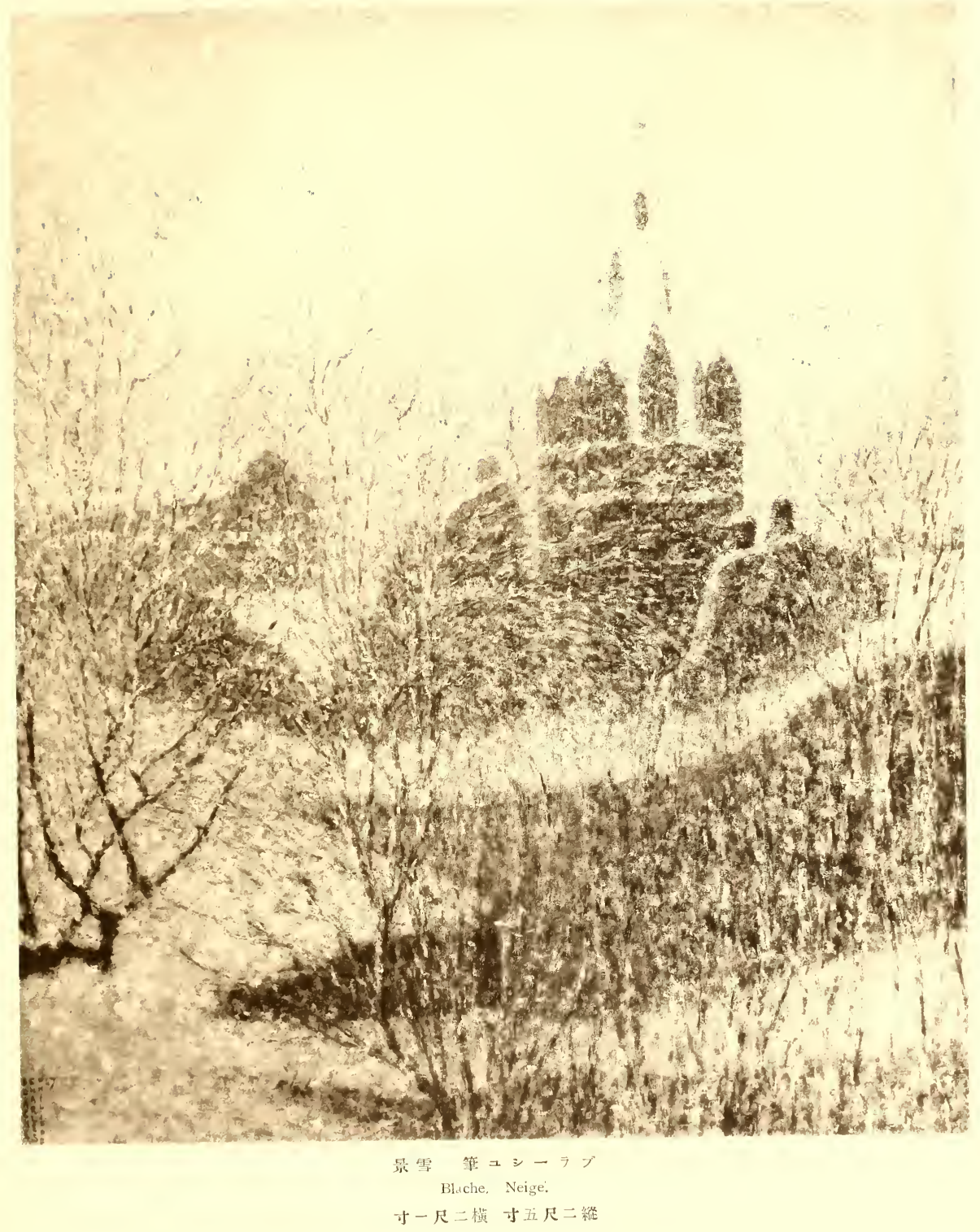


No. 90

\section{PHILIPPE CHARLES BLACHE}

FRENCH

Deceased

\section{LA NEIGE}

$$
\text { Pastel }
$$

Height, 291/2 inches; width, 24:3/4 inches

I'T is snow, but snow without cold-snow on the roof ledges and in the crevices; snow on the bare branches of the trees; and snow in the air. The spectator looks from a window or eminence through the interlaced, snow-laden branches of the trees, toward a great church or cathedral, which seems partly buried in the snowfall.

The building is the old church at Grenoble, which Blache painted in all weathers and all seasons, studying it with care under the different meteorological conditions. Another view which he had of it in winter, when the snow was also plentiful, is to be seen in No. 135 among the oil paintings of this collection, with the curious mountain known as "le casque de Néron" in the background. Both spire and mount, seen from a slightly different point of view, appear again in the pastel No. 89 of the collection, the season then being Spring.

Signed at the lower left, dated $189+$ and $189 \pi$, and numbered $4 \%$. 


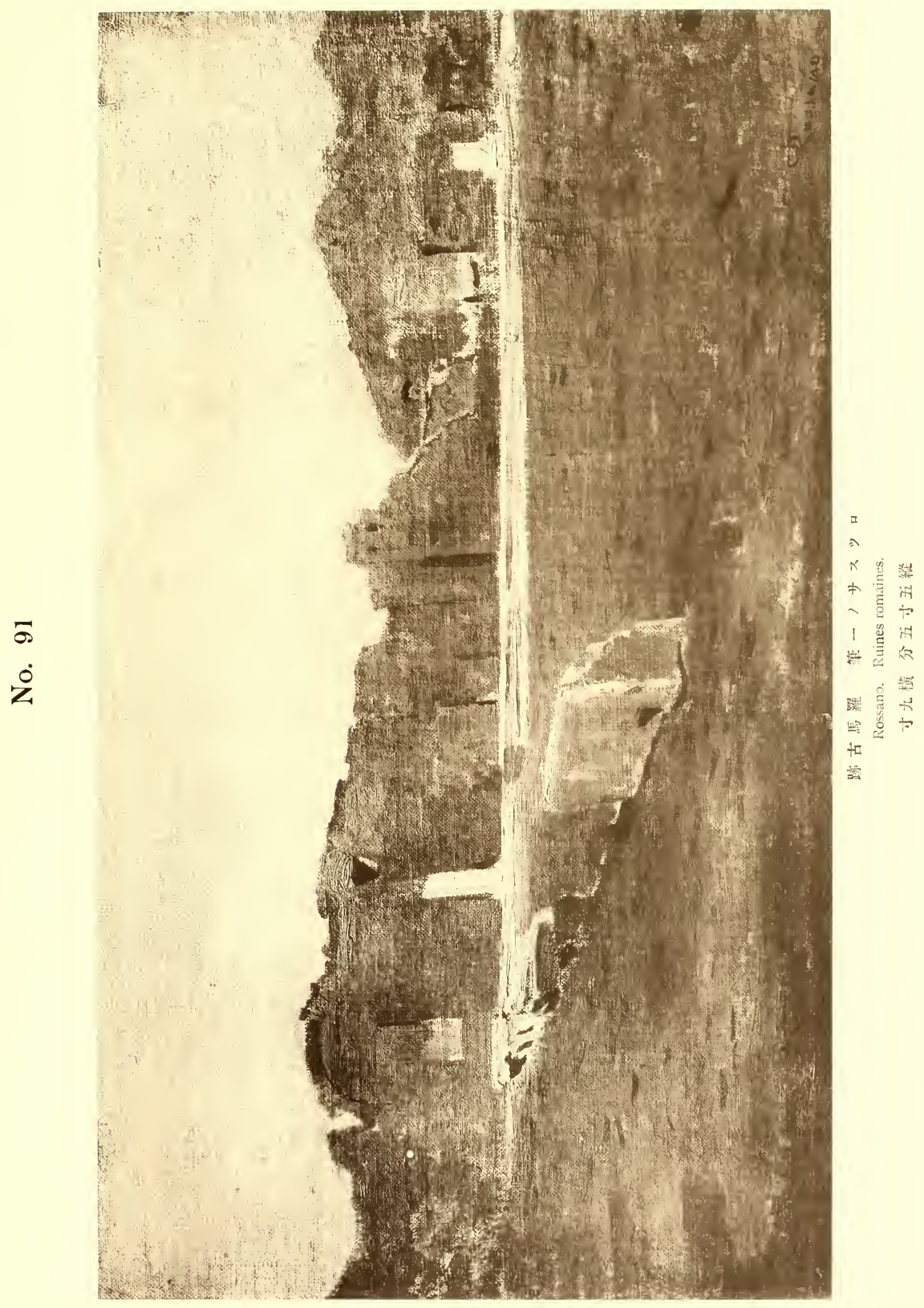


No. 91

E. ROSSANO

ITALIAN

Contemporary

RUINES ROMAINES

Height, $61 / 2$ inches; length, $101 \%$ inches

A sкEтch of some ancient ruins-irregularly broken walls - of dull reddish tone, over a sand-colored plain,and in the distance two wooded mountain summits under a blue sky.

Signed at the lower right, Rossano. 
No. 92

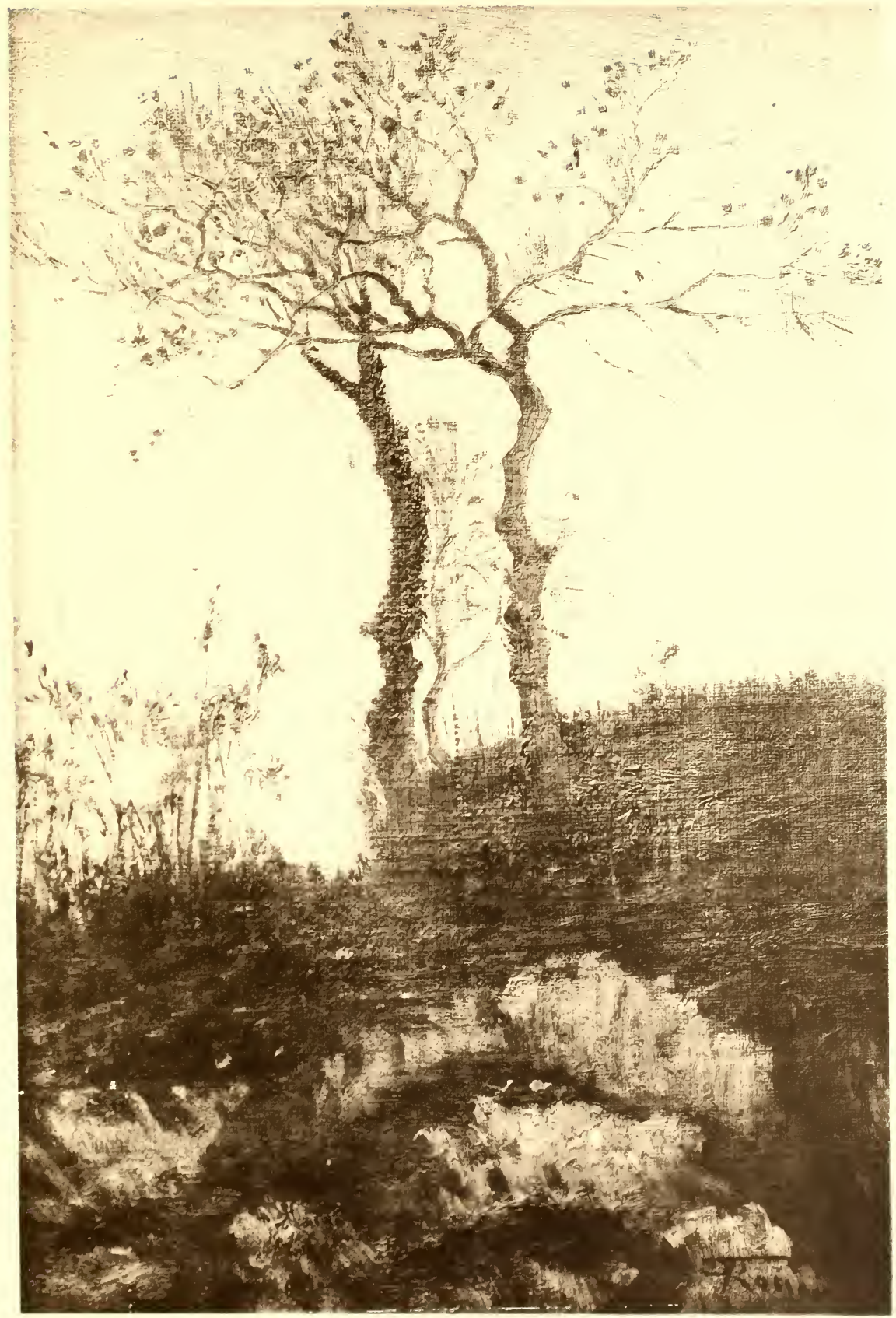

木㴻管一ノサスッ口

Rossano. Arbres en automne.

分五可五横分五才八豵 
No. 92

\section{E. ROSSANO}

ITALIAN

Contemporary

\section{ARBRES EN AUTOMNE}

Height, 10:/4 inches; width, 6 inches

A FEw rocks in the foreground, the crest of a rolling field,- - and two scraggly trees rising against a leaden sky. Their leaves have mostly fallen. Up the trunk of one the clinging ivy is still green. At the foot of the trees a few scrawny field growths, yellowed of autumn, rise over the dark green grass.

Signed at the lower right, Rossano. 


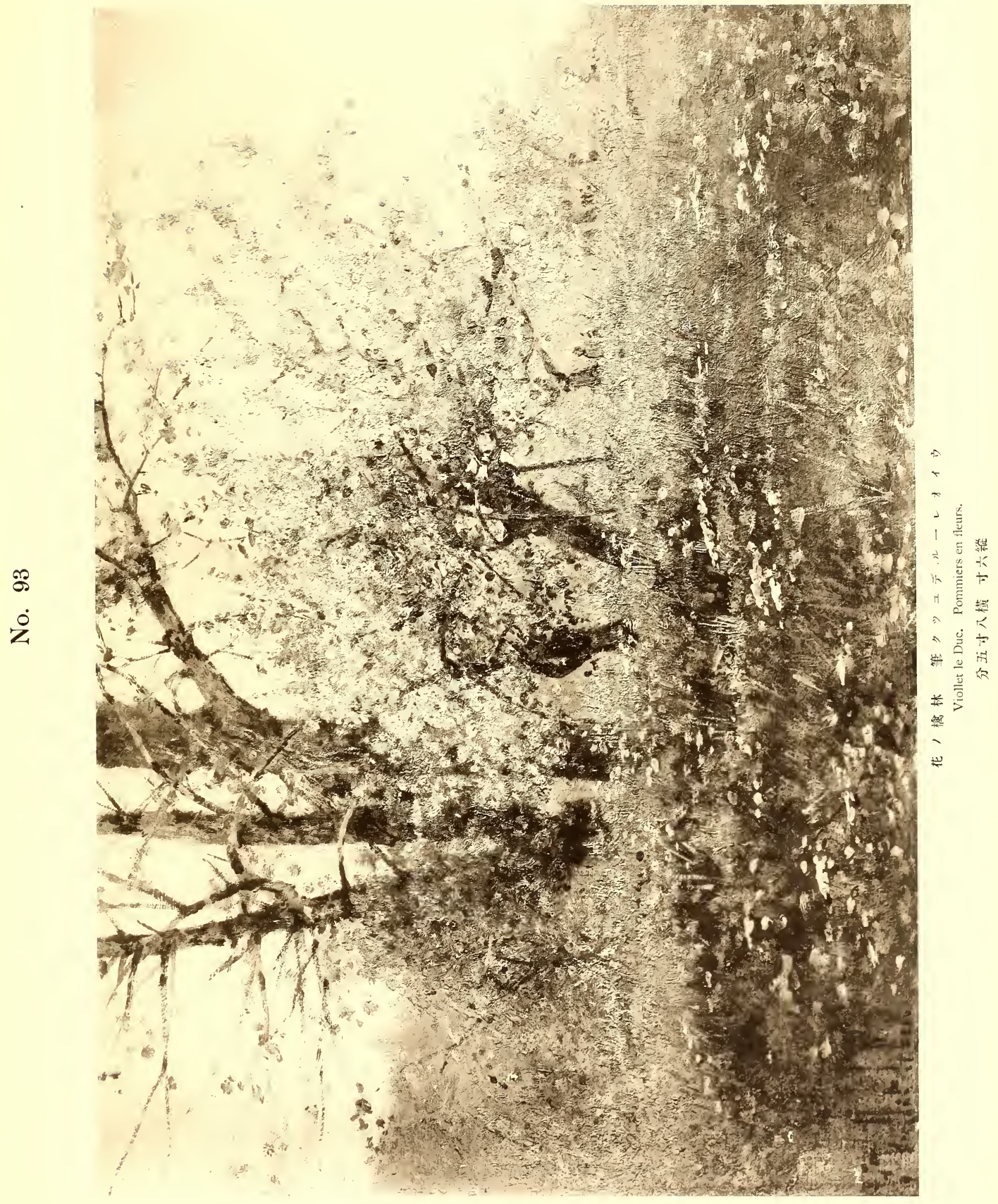


No. 93

\section{VICTOR VIOLLET LE DUC \\ FRENCH \\ Contemporary}

\section{POMMIERS EN FLEURS}

Panel

Height, $\%$ inches; length, 10 inches

Ix an open field freshly carpeted with the bright green Spring grass, lines of apple trees are ablaze with their white and pink blossoms, which in profusion adorn the scrawling and irregular branches. In the middle distance are discerned the figures of people who have come out to enjoy the season of these ever-fascinating arboreal flowers.

Signed at the lower left, I'. Viollet le Duc. 


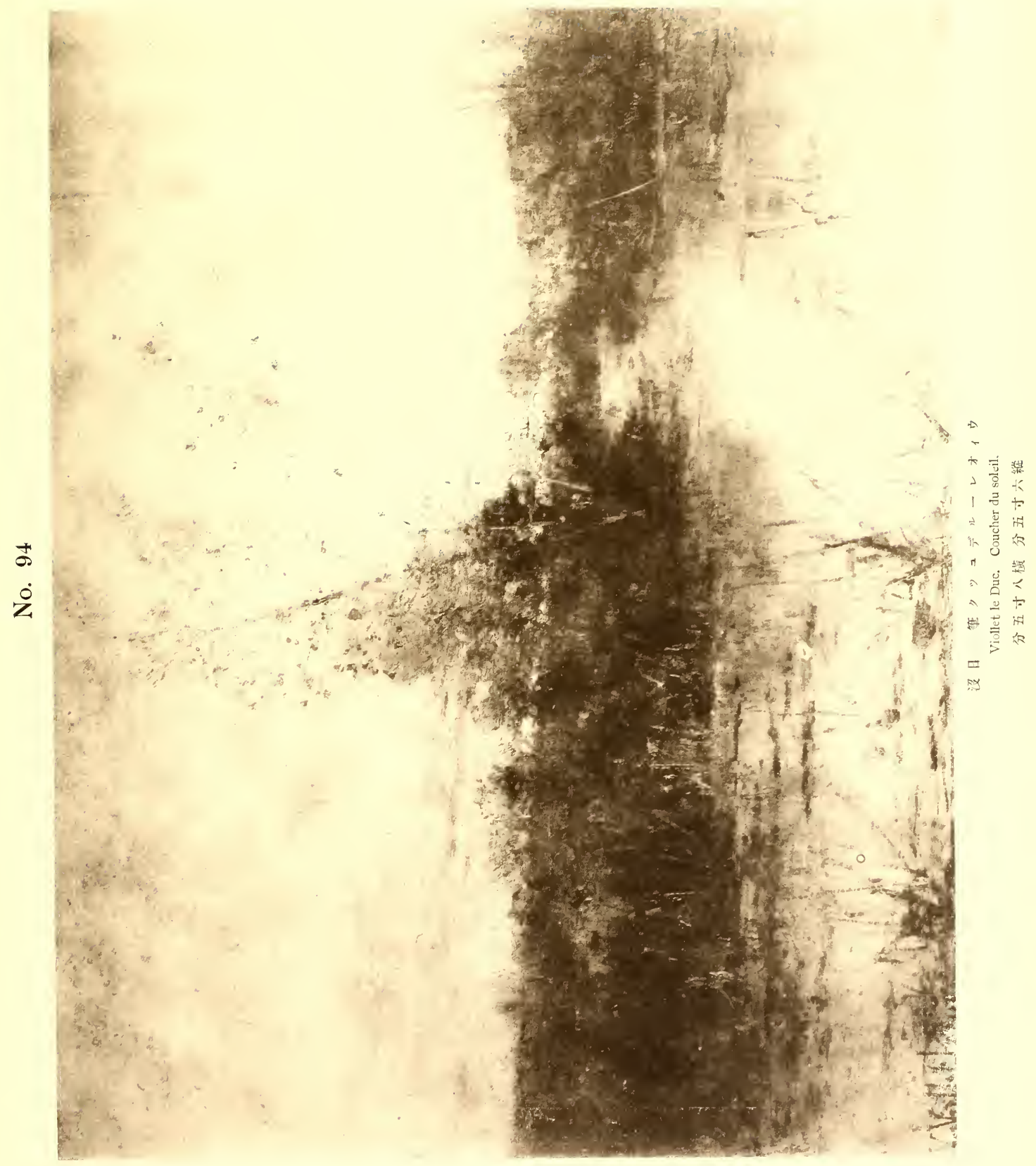


No. 94

\title{
VICTOR VIOLLE'T LE IUC
}

\section{FRENCH}

Contemporary

\section{COUCHER DU SOLEIL}

\author{
Pancl \\ Height, $7 \% / 4$ inches; length, 10 inches
}

THE blue water of a river which overspreads the foreground, and is seen extending back into the landscape, mirrors a robin's-egg blue sky. The river's course is through a land mainly low, and gently sloping to the right. In the middle distance at the water's edge a slender tree or two rises, on the left; and beyond them, at the far horizon, the sun is sinking in a pink glow below the low land.

Signed at the lower left, I. Viollet le Duc. 


\section{No. 95}

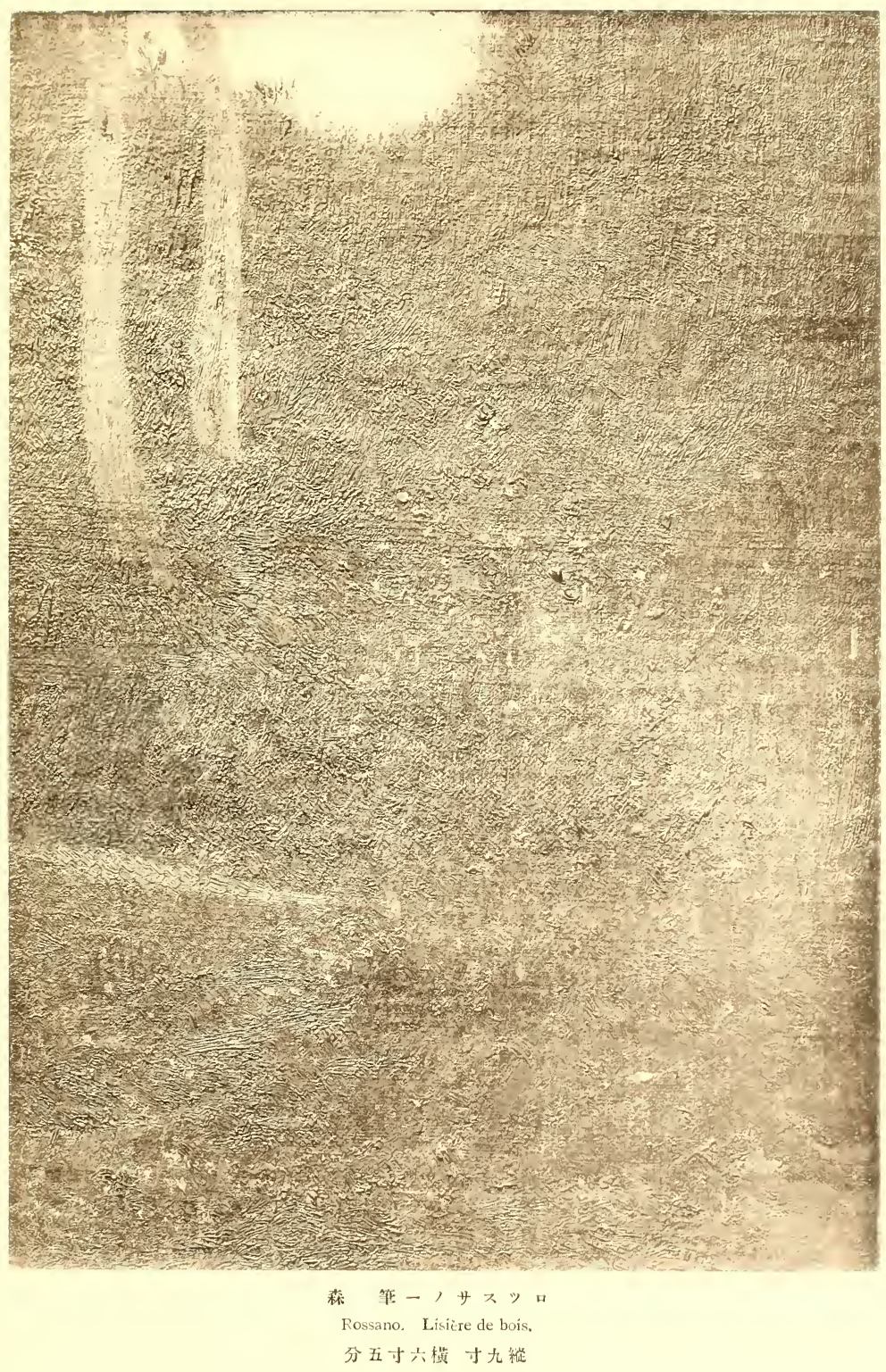


No. 95

\section{E. ROSSANO}

ITALIAN

Contemporary

\section{LISIERE DU BOIS}

Height, 103/4 inches; width, 7 inches

Here is pictured a shallow gully at the edge of a wooda tall bush at its foot; its sides, up and between which the spectator looks, lined with abundant green underbrush. A little $\mathrm{V}$ - or $\mathrm{U}$-shaped patch of sky is visible at its farther end as the eye follows its upward course.

Signed at the lower right, Rossano. 


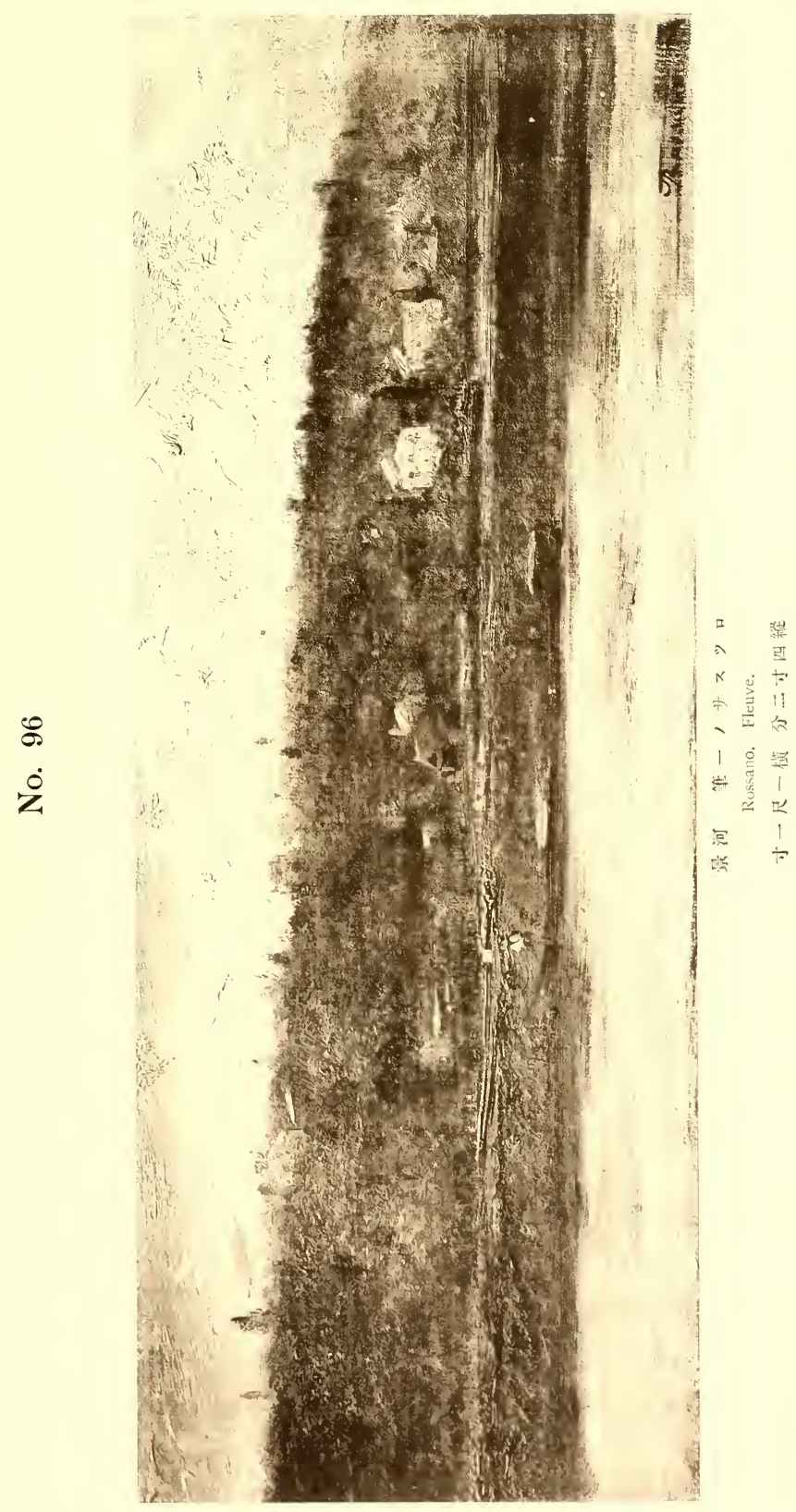


No. 96

\section{E. ROSSANO}

ITALIAN

Contemporary

\section{LE FLEUVE}

Hcight, 5 inches; length, 13 inches

A Long, low, flat boat, setting well down in the water, is seen in the central foreground, in the broad river which flows across the canvas, its farther bank high, mudbordered and grass-topped. Beyond the level plain which forms the grassy bank-top, the land rises at an easy slope; and plain and hillside are dotted with cottages, roughly sketched amid indeterminate trees.

Signed at the lower right, Rossano. 


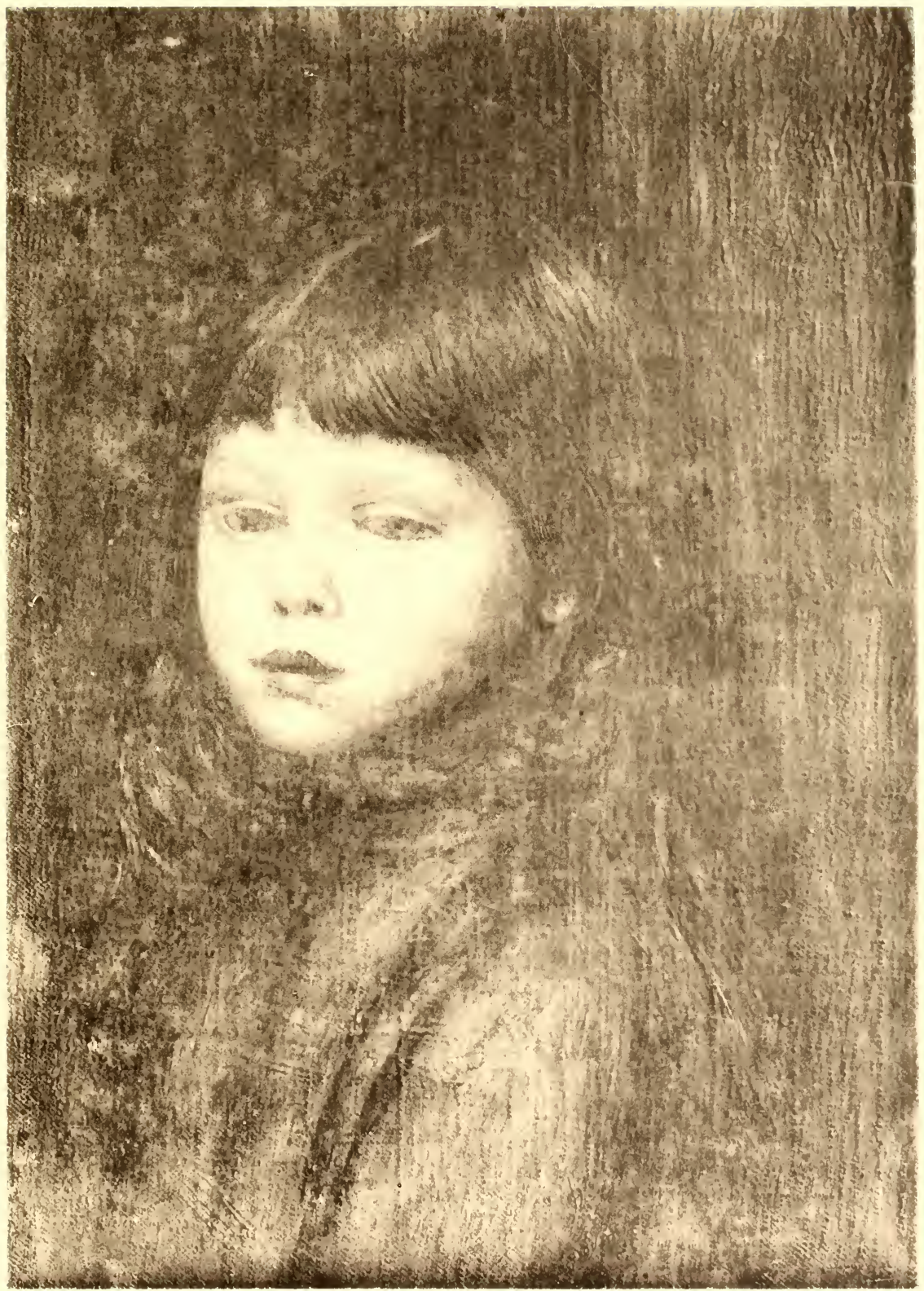

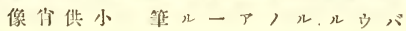

Renoir. Portrait d'enfant.

寸六横分五寸八維 
No. 97

\section{FIRMIN-AUGUSTE RENOIR \\ FRENCH \\ 1841 -}

PORTRAIT D' ENFANT

Height, 101/2 inches; width, $71 / 2$ inches

THE portrait of a pudgy-faced, golden-haired child with large, deep blue eyes and rosy cheeks, who is shown head and shoulders and facing the left, the head turned threequarters toward the spectator. The child is clad in a rough blue jacket. 'The hair, which falls loosely over the shoulders, is brushed smoothly down in front, in a straight bang, over the low forehead.

Signed at the upper right, Renoir. 


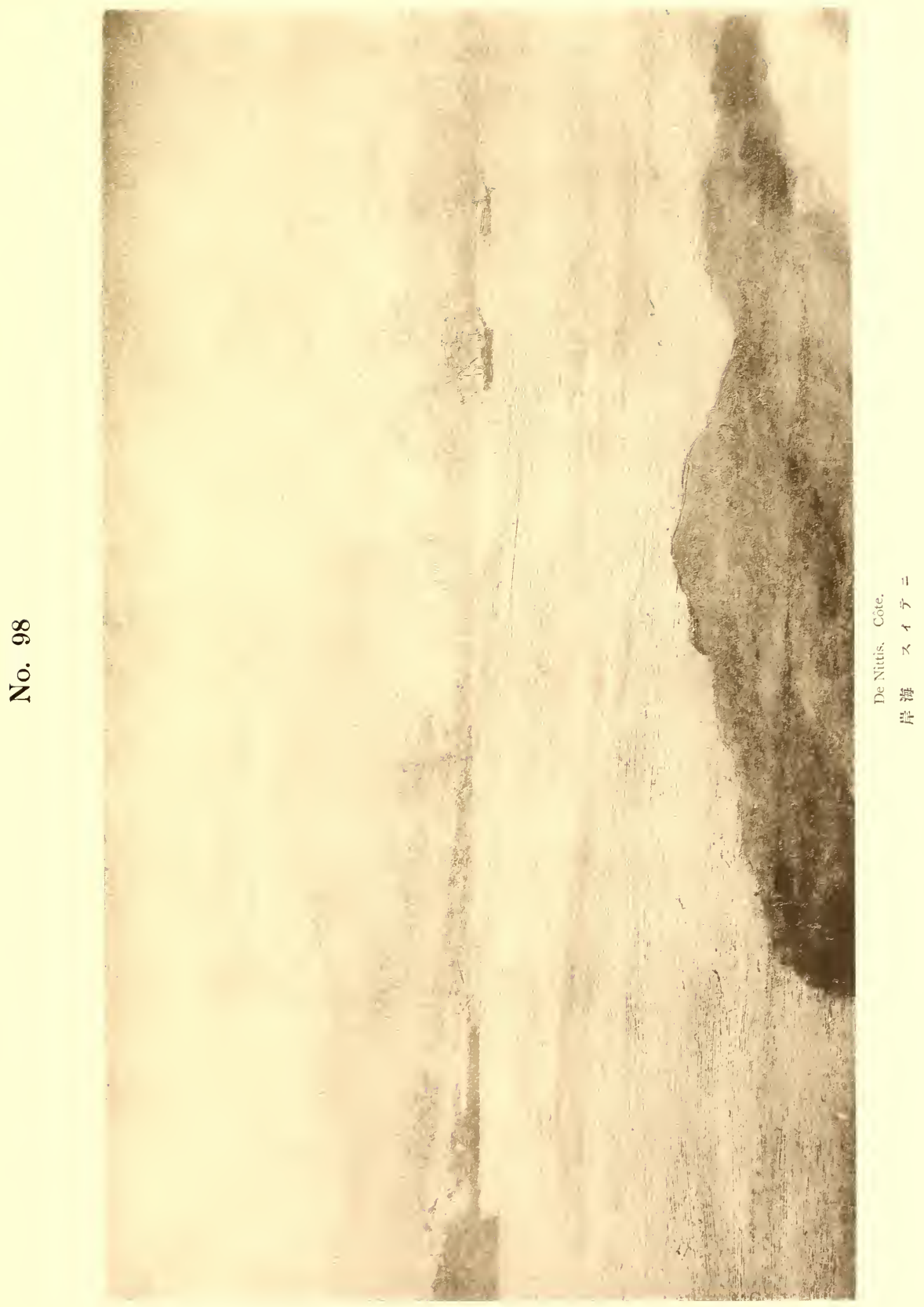


No. 98

\section{GIUSEPPI DE NI'T'TIS}

ITALIAN

$1846-1884$

\section{LACOTTE}

\section{Panel}

Height, 61/2 inches; length, 113/4 inches

A PAxel sketch of a mountainous and rocky coast, perhaps Italian, and a partly landlocked bay on which some black-hulled sailing ships, of square rig, ride at anchor in the distance. The rocks are of burnt orange tinge, the hill or mountain tops are obscured in purple mists, and the quiet water is of the hue of the green turquoise-a big land- and sea-scape within small compass.

Signed at the lozer right, De Nittis. 


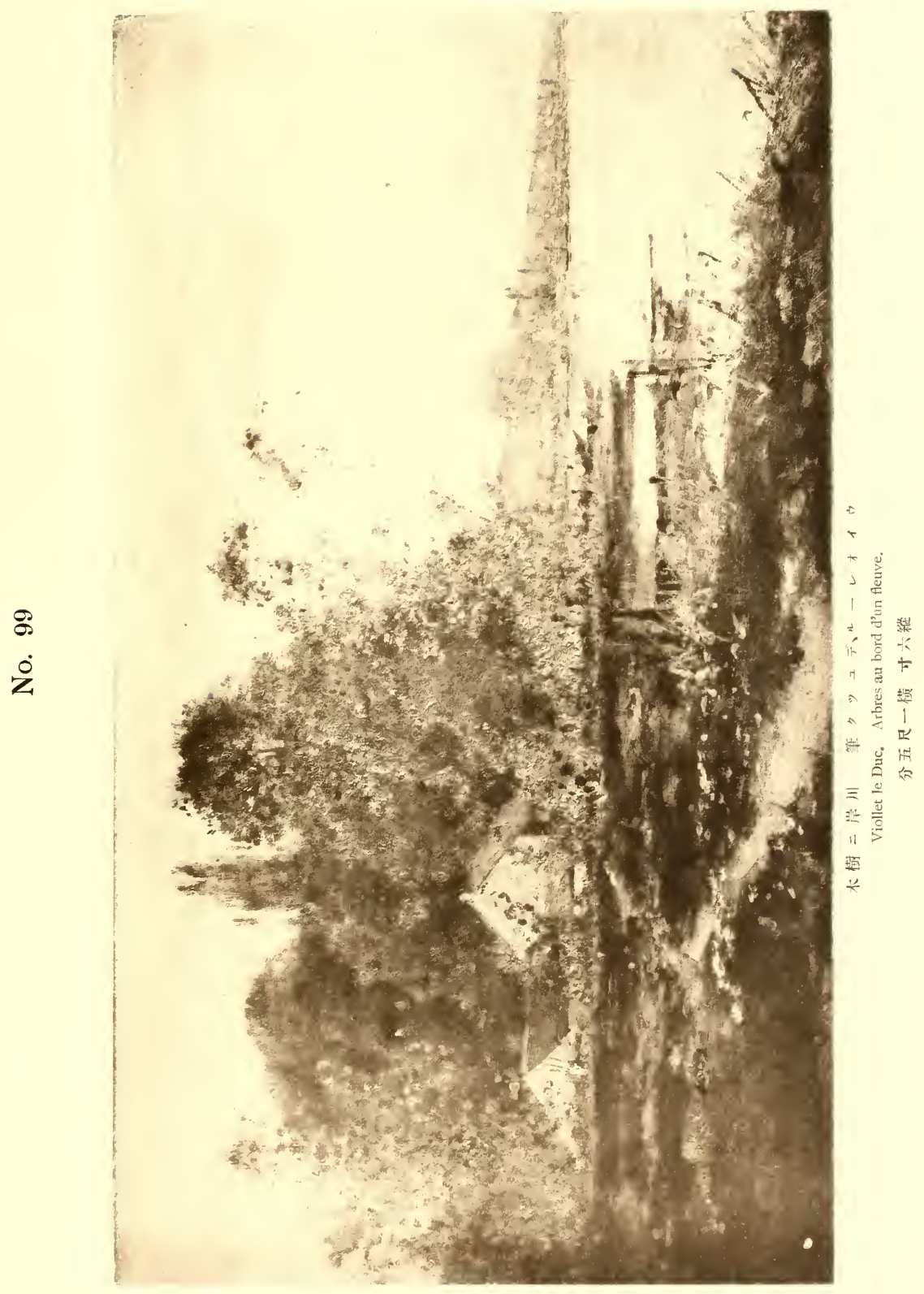


No. 99

VIC'TOR VIOLLE'T LE DUC FRENCH

Contemporary

ARBRES AU BORD D'UN FLEUVE

Panel

Height, 7 inches; length, 121/2 inches

In the tones and the quality of the water and the sky there is a suggestion of Boudin here,-in the blue river which moves slowly at the right, under a sky less blue only because of the multitude of gray-white clouds which make the great world-dome populous. 'The foreground presents low-lying green fields, which are crossed by a riverside footpath leading to a cottage sheltered beneath a compact group of trees that give to the picture its title. At the right the broad river sweeps in a great bend, indenting the left-hand shore, and long rowboats rest at intervals with their noses against the grassy bank.

Signed at the lower left, V. Viollet le Duc. 


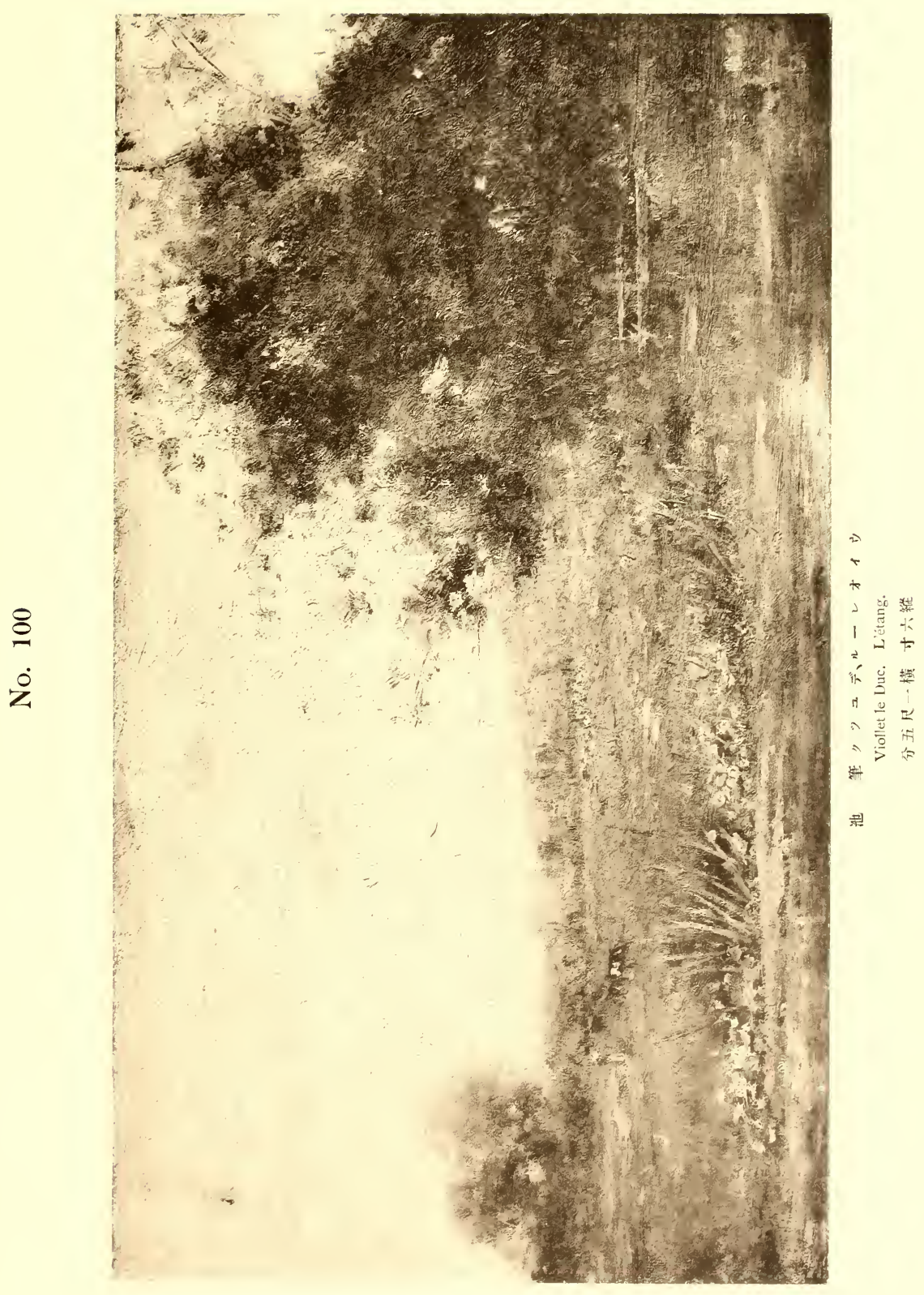


No. 100

\title{
VICTOR VIOLLET LE DUC \\ FRENCH
}

Contemporary

L'ETANG

\author{
Panel \\ Height, 7 incles; length, 121/2 inches
}

ONe corner of a pond appears in the foreground-blue, save where its limpid sheen reflects the rushes and verdure of a bordering meadow at the left, whereon cattle graze. At the right arises a mass of low, bush-like trees, at whose base the shadows deepen over the water.

Signed at the lower left, I'. Viollet le Duc. 


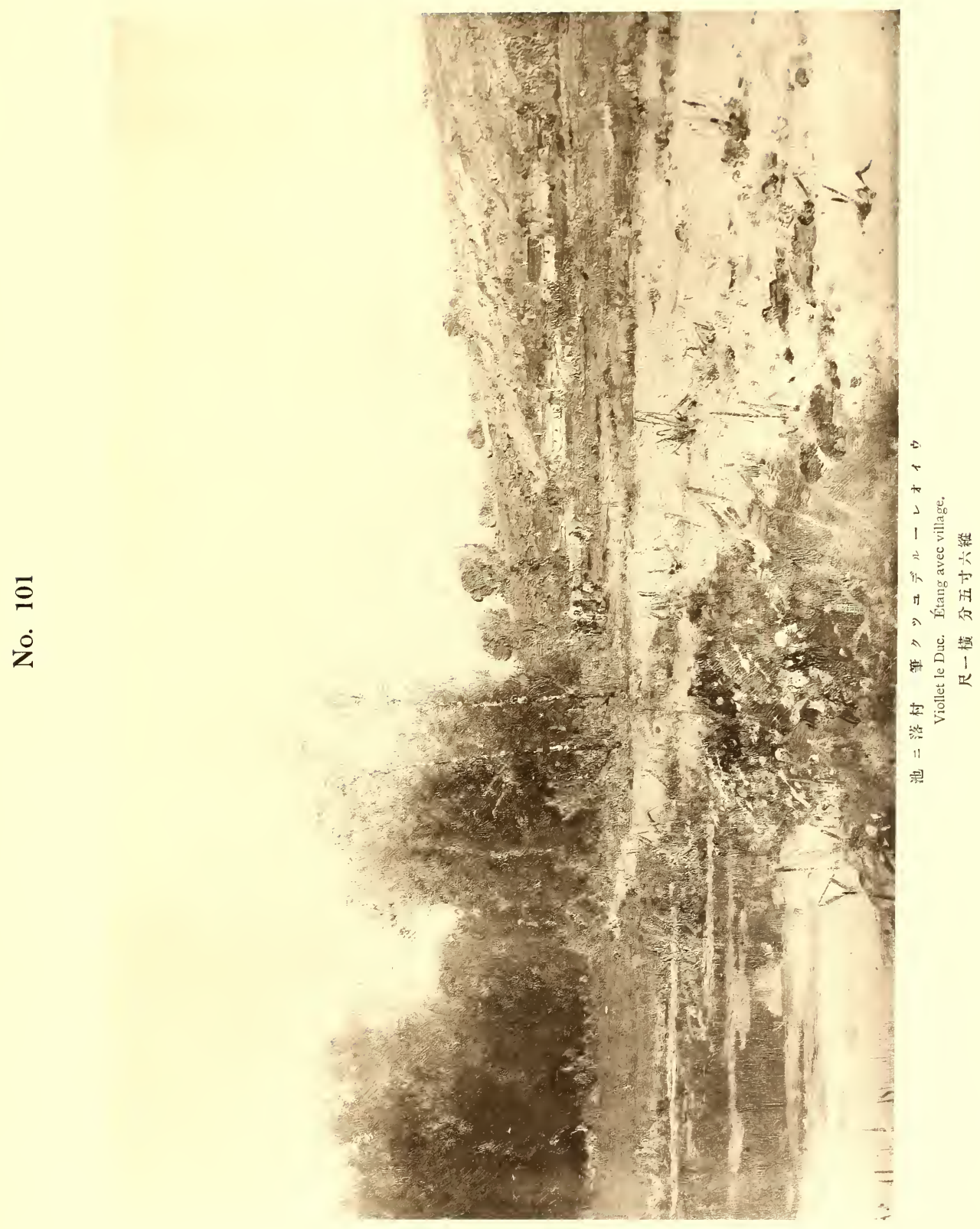


No. 101

\section{VICTOR VIOLLET LE DLC \\ FRENCH \\ Contemporary}

\section{E'TANG AVEC IILLAGE}

Pancl

Height, 8 inches; length, 12 inches

AT the left the head of a pond is seen, coming up, in the foreground, to a broad, irregular road, which, extending into the distance, is lost amongst a grove of trees beyond the pond. To the right of the road, in the middle distance, the houses and other buildings of a village, with red roofs visible here and there, are banked against a green hillside which forms the boundary of the picture. Some of the villagers are seen about, in the bright light of a clear day.

Signed at the lower left, V. Viollet le Duc. 
No. 102

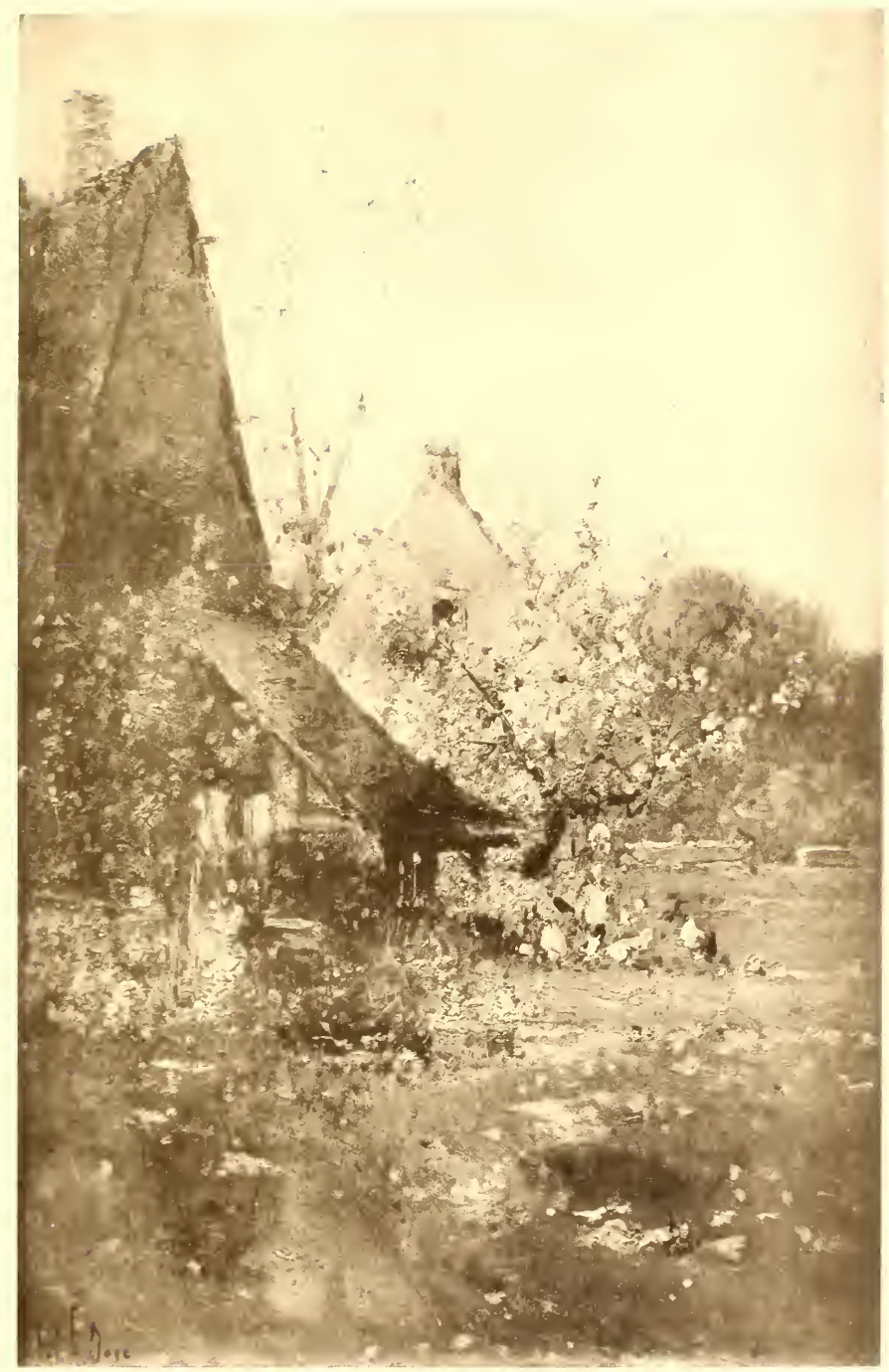

家舍田, 等》”ュデーレオイウ

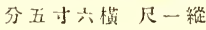


No. 102

\section{VICTOR VIOLLET LE DUC \\ FRENCH}

Contemporary

\section{PRINTEMPS}

\section{Panel}

Height, 12 inches; width, 8 inches

THE gable of a high-peaked roof, surmounted by a red chimney top, abuts at the left of the composition before the end elevation of another high gabled building, both apparently dwellings in a kindly country. A blossoming apple tree intervenes between the houses, and beneath it at the end of a shed, or lean-to, a woman has scattered feed for the chickens, which cluster about her on the sward.

Signed at the lower left, Viollet le Duc. 


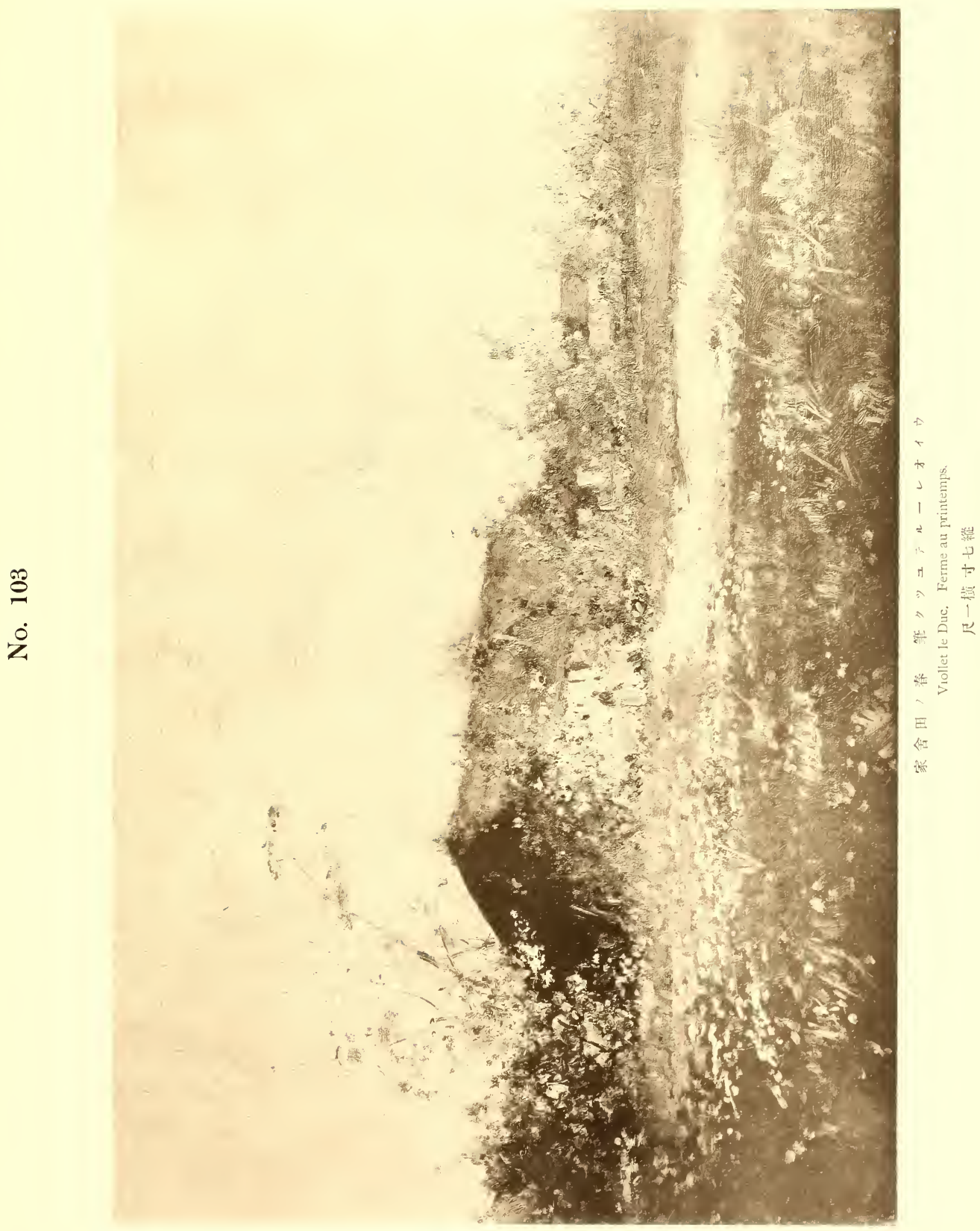


No. 103

\section{VICTOR VIOLLET LE DUC FRENCH \\ Contemporary}

FERME AU PRINTEMPS

Panel

Height, 8 inches; length, 12 inches

A brilliant moment made permanent. The charm of a gloriously bright Spring day, when all Nature was singing in the country, becomes potent, personal and direct, in a pigment so delicate that the medium itself is forgotten. Thatched-roof farm houses and outbuildings are almost screened from sight by a wealth of blossoming trees and shrubs and plants, which surround them, in a level green field as fresh as the season itself. Before one of the cottages a woman in a red waist and blue skirt brings humanity into touch with the vernal beauties of outdoors.

Signed at the lower left, V. Viollet le Duc.

A pendant to No. 104 . 


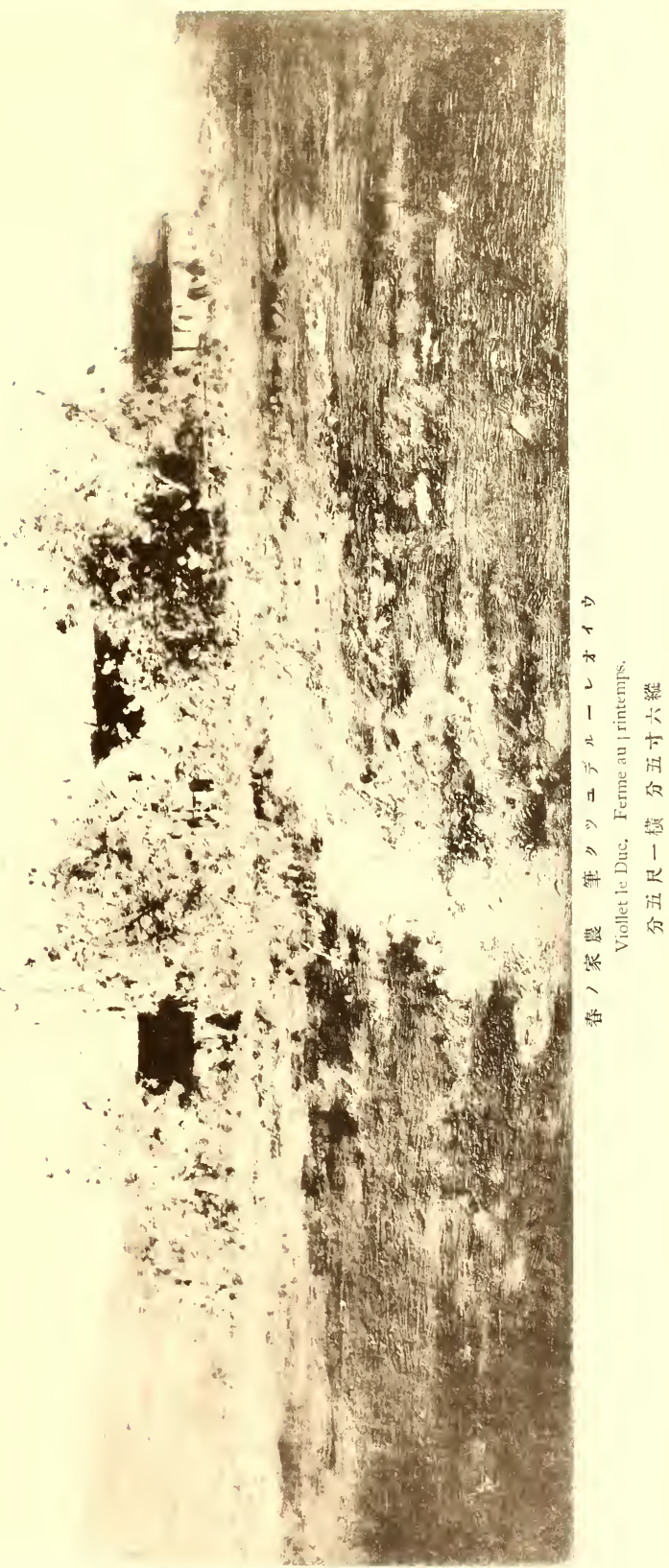


No. 104

\section{VICTOR VIOLLE'T LE DUC \\ FRENCH}

Contemporary

FERME AU PRINTEMPS

Pancl

Height, 8 inches; length, 12 inehes

A French farm house with its outbuildings is seen-or part of the group is seen - in the center of a flat plain at the edge of a low, round-topped hill. Abundant foliage on slender limbs and branches rises before and over some of the buildings, screening them from view. A haphazard footpath winds over the verdant plain toward the main cottage, losing itself to sight before the door in the luxuriant new greenery of tree and bush surrounding the dwelling. Over all is a kindly sky of pale azure, beyond a low floating mass of vaporous fleece.

Signed at the lower left, V. Viollet le Duc.

A pendant to No. 103. 


\section{$\stackrel{10}{9}$}

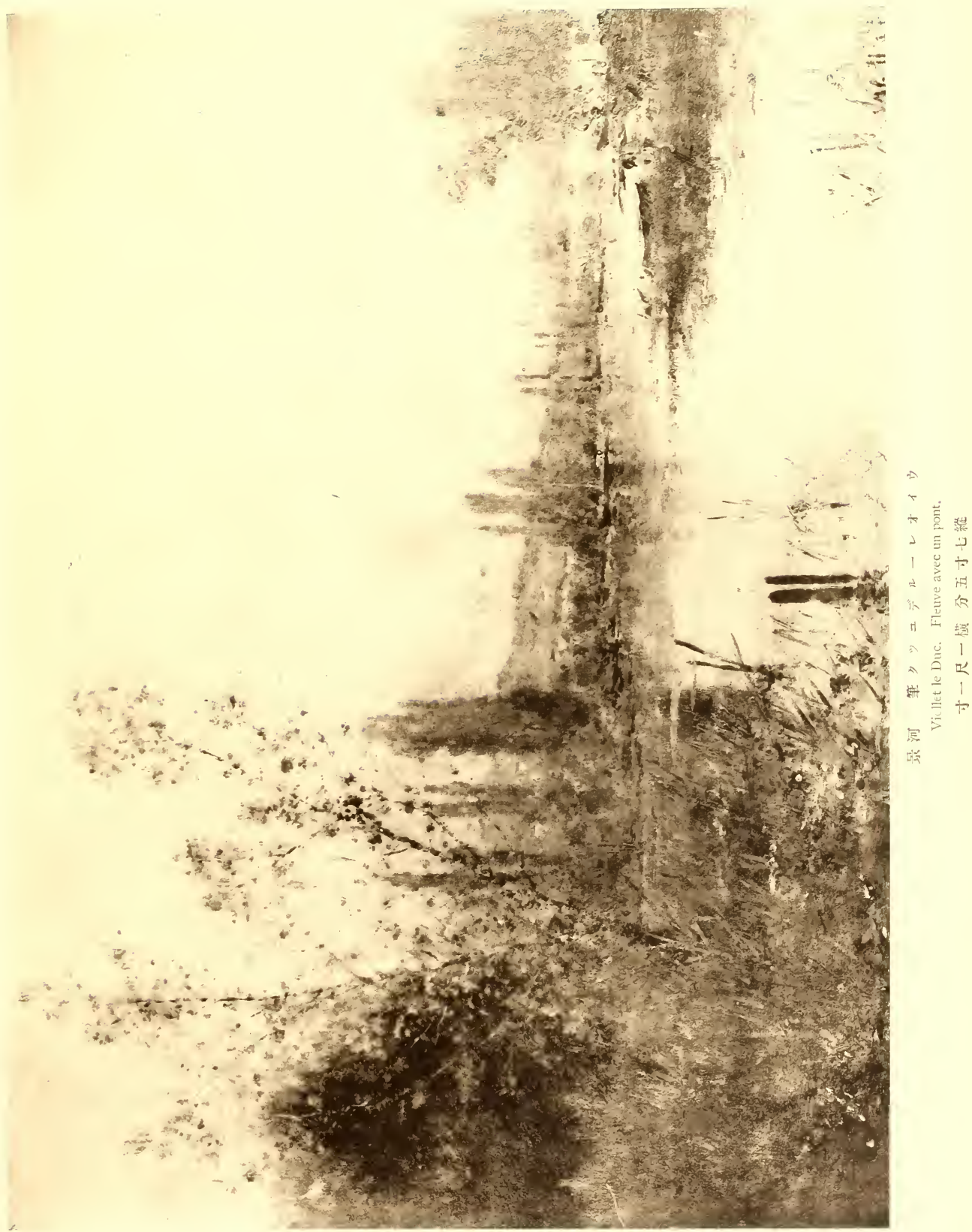


No. 10.5

\section{VICTOR VIOLLET LE DUC}

FRENCH

Contemporary

\section{FLELIE AYEC UN PONT}

\section{Panel}

Height, 91/2 inches; length, 13 inches

A PLAcid river pursues its winding course through green fields, - with lush verdure covering the low banks to the water's edge,--and amid detached Lombardy poplar trees, which stand in small groups and singly, like highplaced sentinels, overlooking the landscape. At either bank, in the middle distance, small boats are drawn up, and on a point of land two men have disembarked from one of these. In the distance the eye perceives the gray arches of a stone bridge crossing the pastoral stream.

Signed at the lower right, V. Viollet le Duc. 


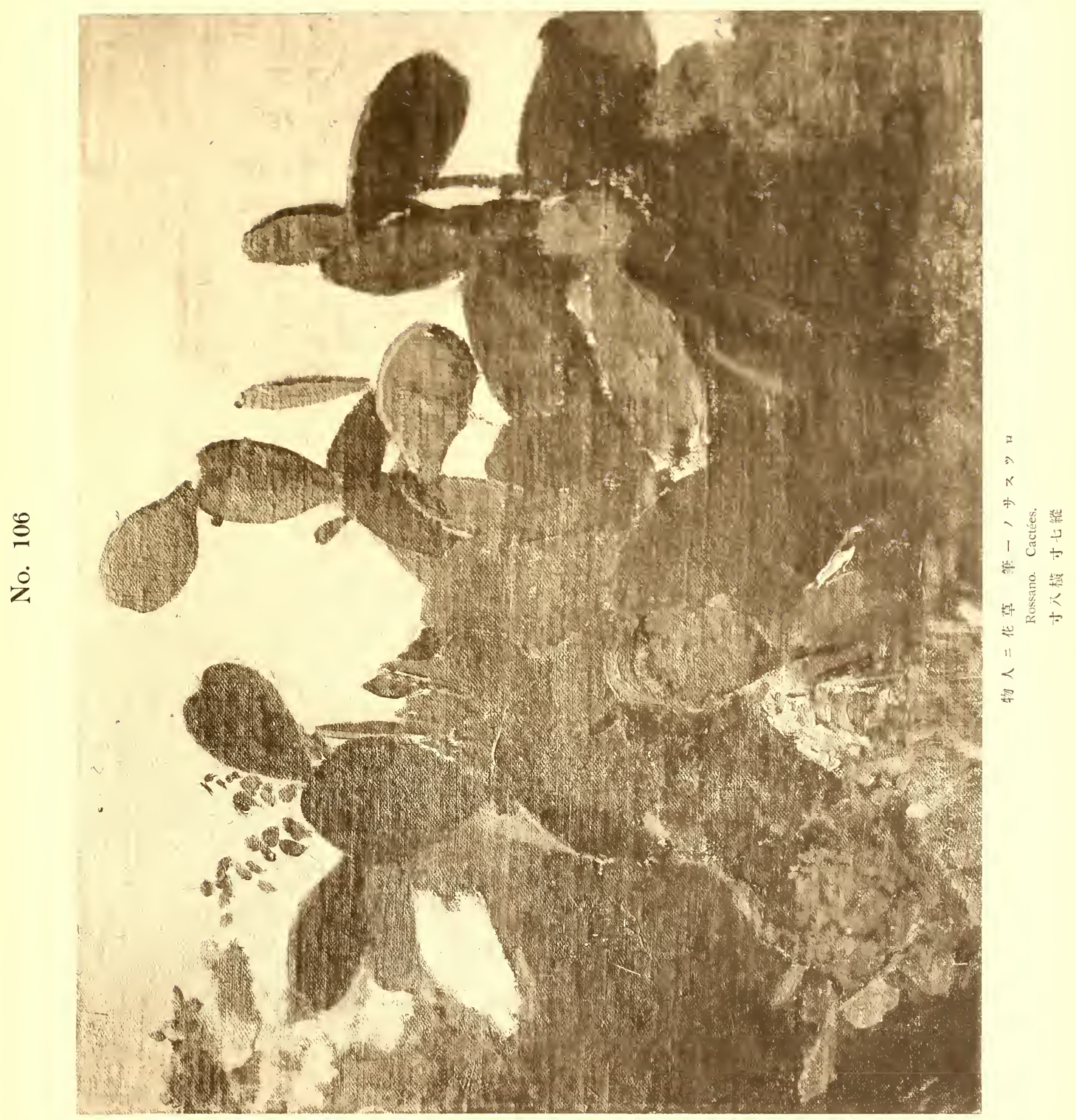


No. 106

\section{E. ROSSANO}

ITALIAN

Contemporary

\section{CACTUS}

Height, 81/2 inches; length, 10 inches

THE picturesque forms which the wilful cactus takes have caught the artist's eye for a natural composition. The sturdy plants, green and a dullish red, raise their bulky outlines in an irregular and picturesque group, below which a black-haired, grim-risaged youth or man, in a red fez, is seen, shoulder-high, against them. Probably a note for a large picture. A sketch. 


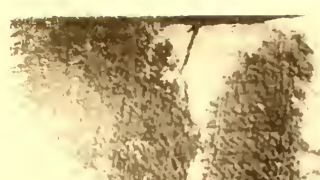

17 45

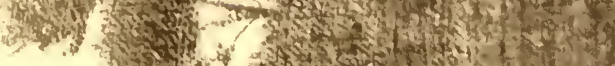

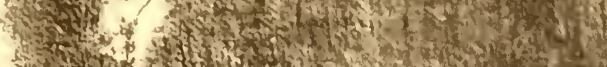

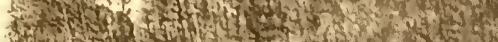

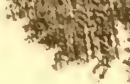

$\dot{8}$

M.

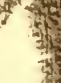

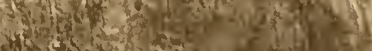

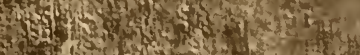

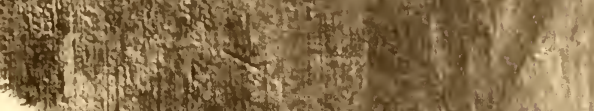

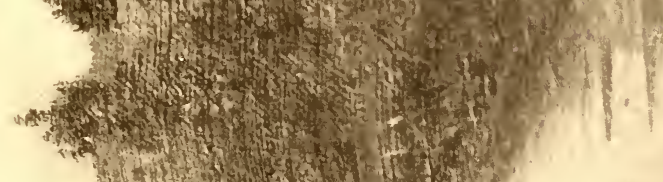


No. 107

\section{E. ROSSANO}

ITALIAN

Contemporary

\section{CHEMIN}

Height, 9 inches; length, 11 inches

A sкетсн, in some parts carried pretty well out, of a flat road or street running straight away from the spectator toward a hill, which rises abruptly in the background and extends across the picture under a clear blue sky. In the middle distance a cart containing two persons with red hats is coming forward in the center of the tree-bordered way.

Signed at the lower left, Rossano. 


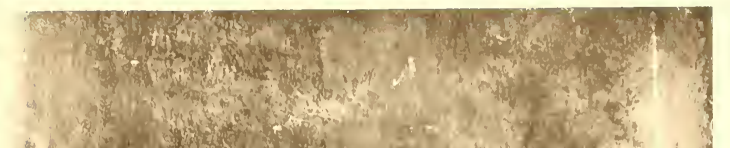

M.

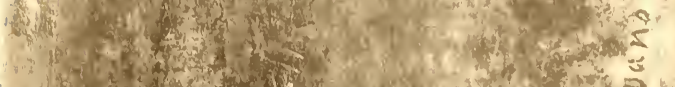

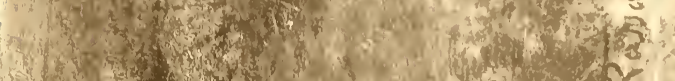

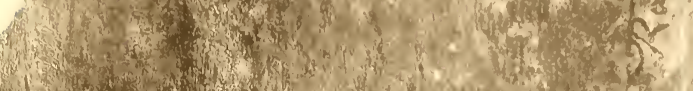

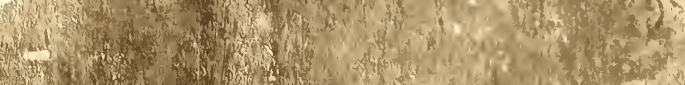

(1)

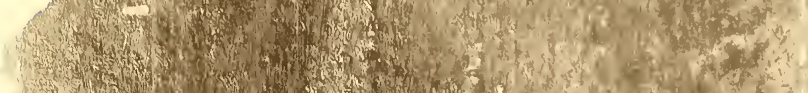

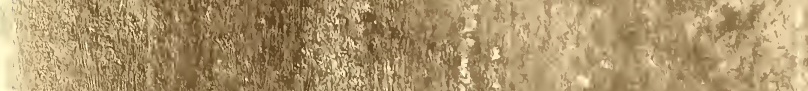

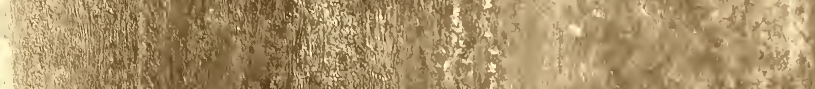
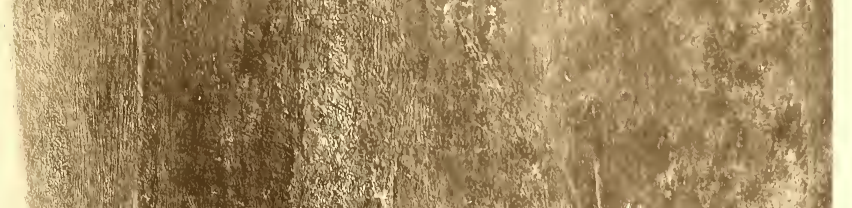

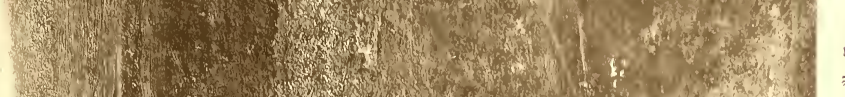

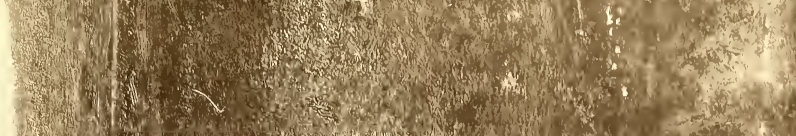

tran

(3)

(1.)

(1)

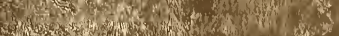

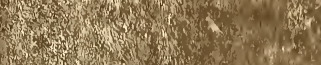

$5+2 x^{2}+2 x^{2}$

2.

7 (1)

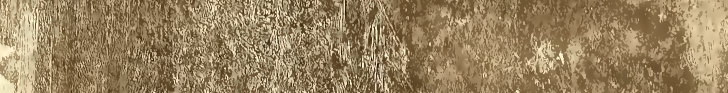

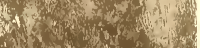

$\lambda$

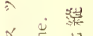

$x{ }^{x}{ }^{2}$

क

, 仅

光它势

$\therefore=$

你

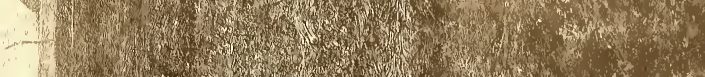

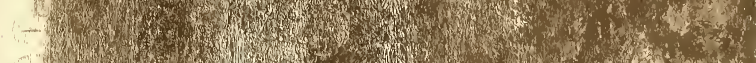

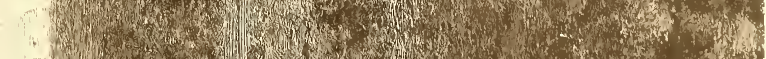

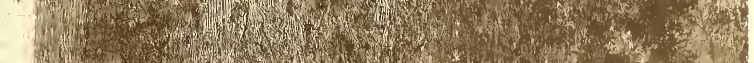

H.

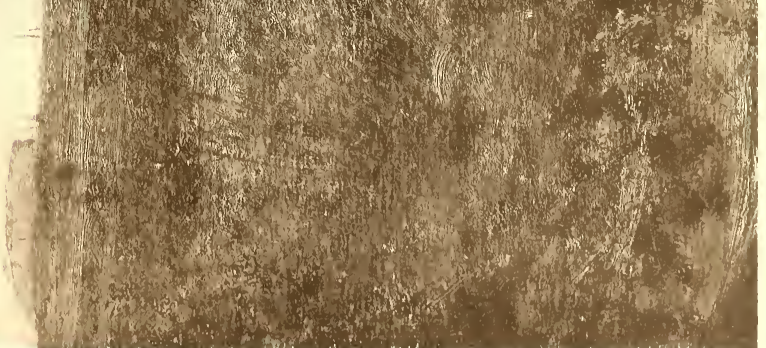


No. 108

\section{E. ROSSANO}

\section{ITALIAN}

Contemporary

\section{DANS LA CAMPAGNE}

Height, 91/2 inches; length, 12 inches

A sкeтch or color note to remind the artist of the green, in a flat meadow, that attracted him on a dull day of Spring or Fall, when the trees were bare of leaves, and brownish bushes rose above the grasses. In the center, the dull mass of a long, reddish-brown building.

Signed at the lower right, Rossano. 


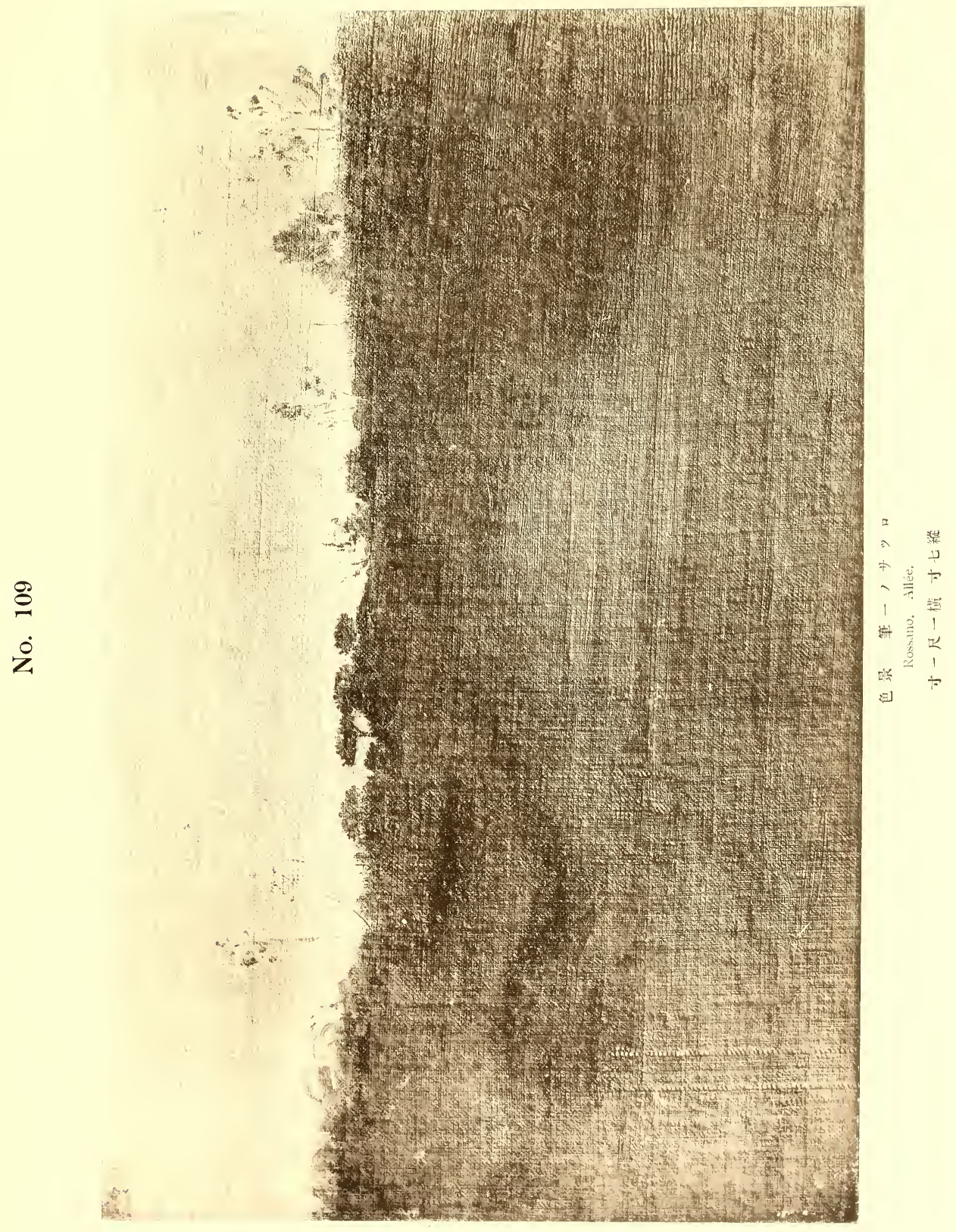


No. 109

\section{E. ROSSANO}

ITALIAN

Contemporary

ALLEE

Height, 8 inches; length, 13 inches

A sketch of shadows, and the last horizontal rays of the setting sun, falling from the left across a narrow country lane, which is somewhat depressed between reddish, sandy banks, that are overgrown with low, green bushes, as the lane leads straight away from the spectator-the shadows appearing a deep brown between the green borders of the roadbed.

Signed at the lower right, Rossano. 
No. 110

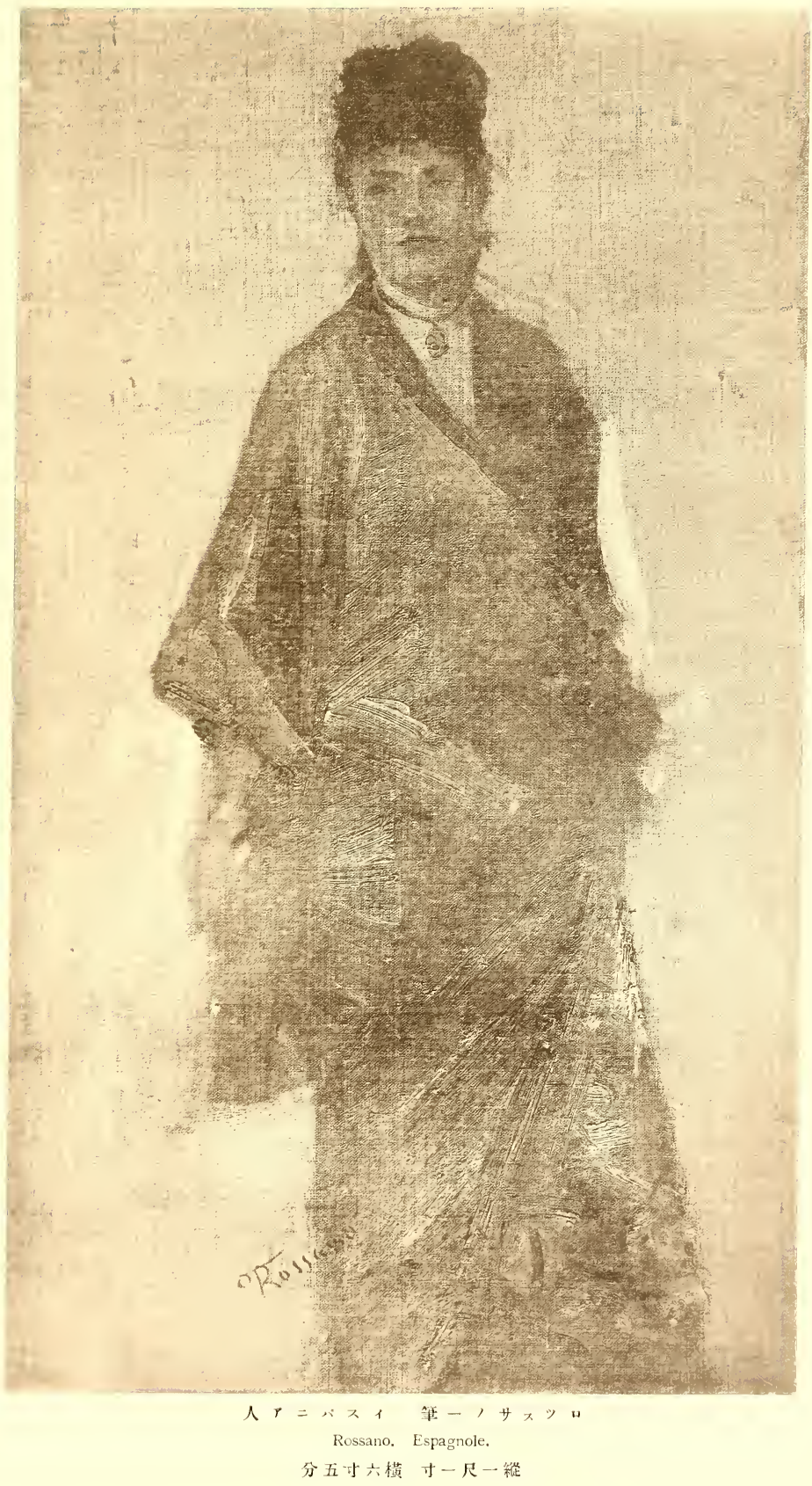


No. 110

E. ROSSANO

ITALIAN

Contemporary

\section{UNE ESPAGNOLE}

Height, 14 inches; width, 81/2 inches

A TALL Spanish woman, with dark eyebrows and a heavy mouth, her dark hair massed above her head, is sketched in an interesting manner at full length, standing, and facing front. Her attitude is one of ease and composure. Her dress of Spanish red is tinged with yellow and black, and she holds at her hip a red fan.

Signed at the lower left, Rossano. 


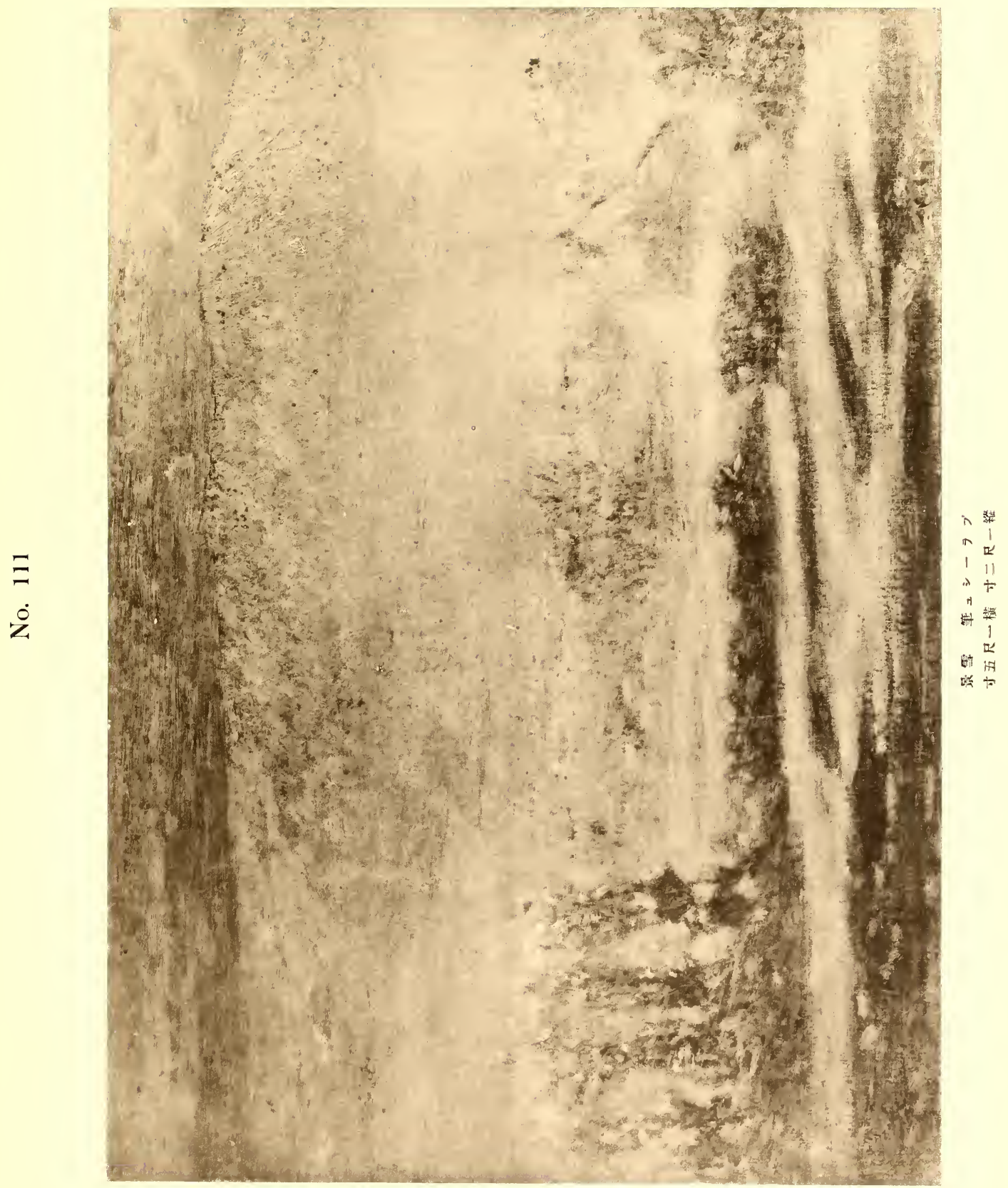


No. 111

\section{PHILIPPE CHARLES BLACHE}

FRENCH

Deceased

\section{LA FIN DU JOUR}

Height, 9112 inches; length, 13 inches

The high and rounded caps of distant mountains rise beyond a misty valley, their scarred sides illumined with only less color than the sunset sky itself behind them. Below, in the middle distance and the foreground, the landscape appears snow-covered and iced over, with bushes and trees iridescent in the cool, late afternoon glow.

Signed at the lower left, dated 1891 and 1896, and numbered 43. 


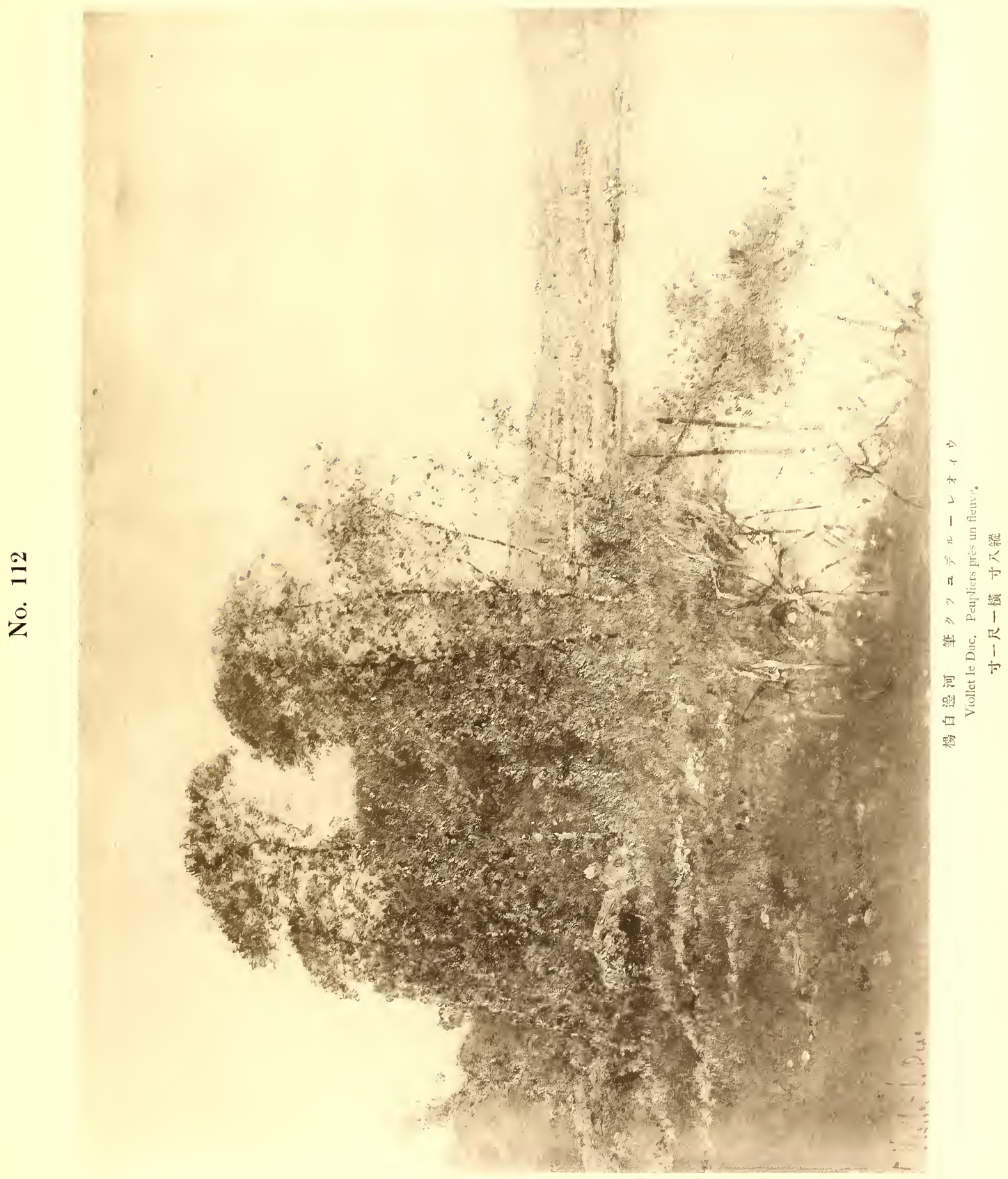


No. 112

\section{VICTOR VIOLLET LE DUC}

FRENCH

Contemporary

PEUPLIERS PRES D'UN FLEUVE

Panel

Height, 91/2 inches; length, 131/2 inches

The bank of a placid river-whose surface takes the hue of the light blue sky-is seen clothed in the tender green of springtime. Wild flowers are blossoming on its borders, at the foot of a group of silvery, graceful, white poplars, near the base of one of which a woman may be discerned seated upon a rock. Boats are busy on a part of the river, and the buildings of a small town dot the farther shore.

Signed at the lower left, I. Viollet le Duc. 


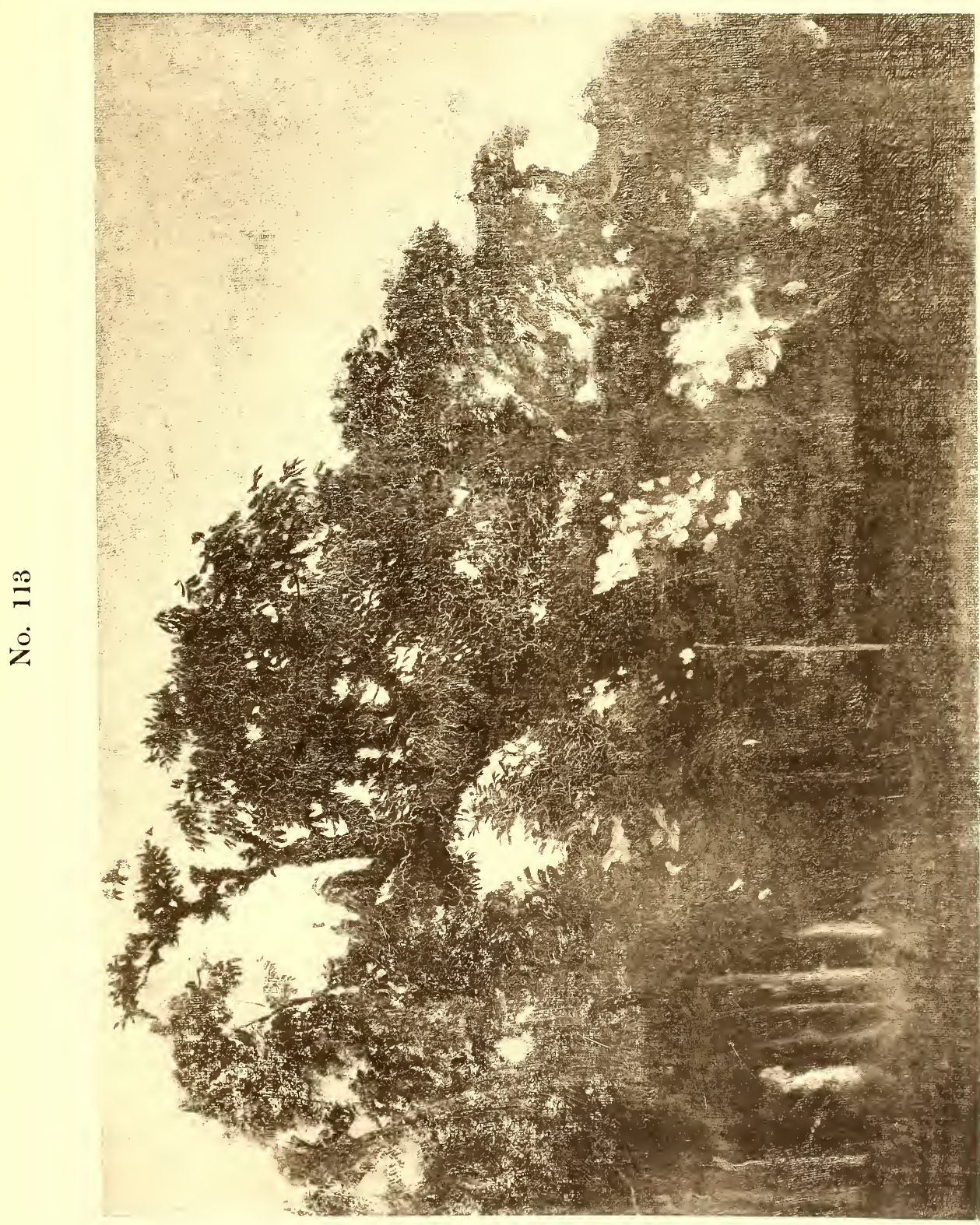

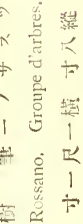


No. 113

\section{E. ROSSANO}

ITALIAN

Contemporary

\section{GROUPE D'ARBRES}

Height, 93/4 inches; length, 133/4 inches

A group of massive trees rises in the central foreground against a turquoise-blue sky. Their heavy trunks are dark against the green background of a neighboring wood at the left, their top branches bathed in sunlight. A sketch with detail for a larger landscape canvas.

Signed at the lower left, Rossano. 


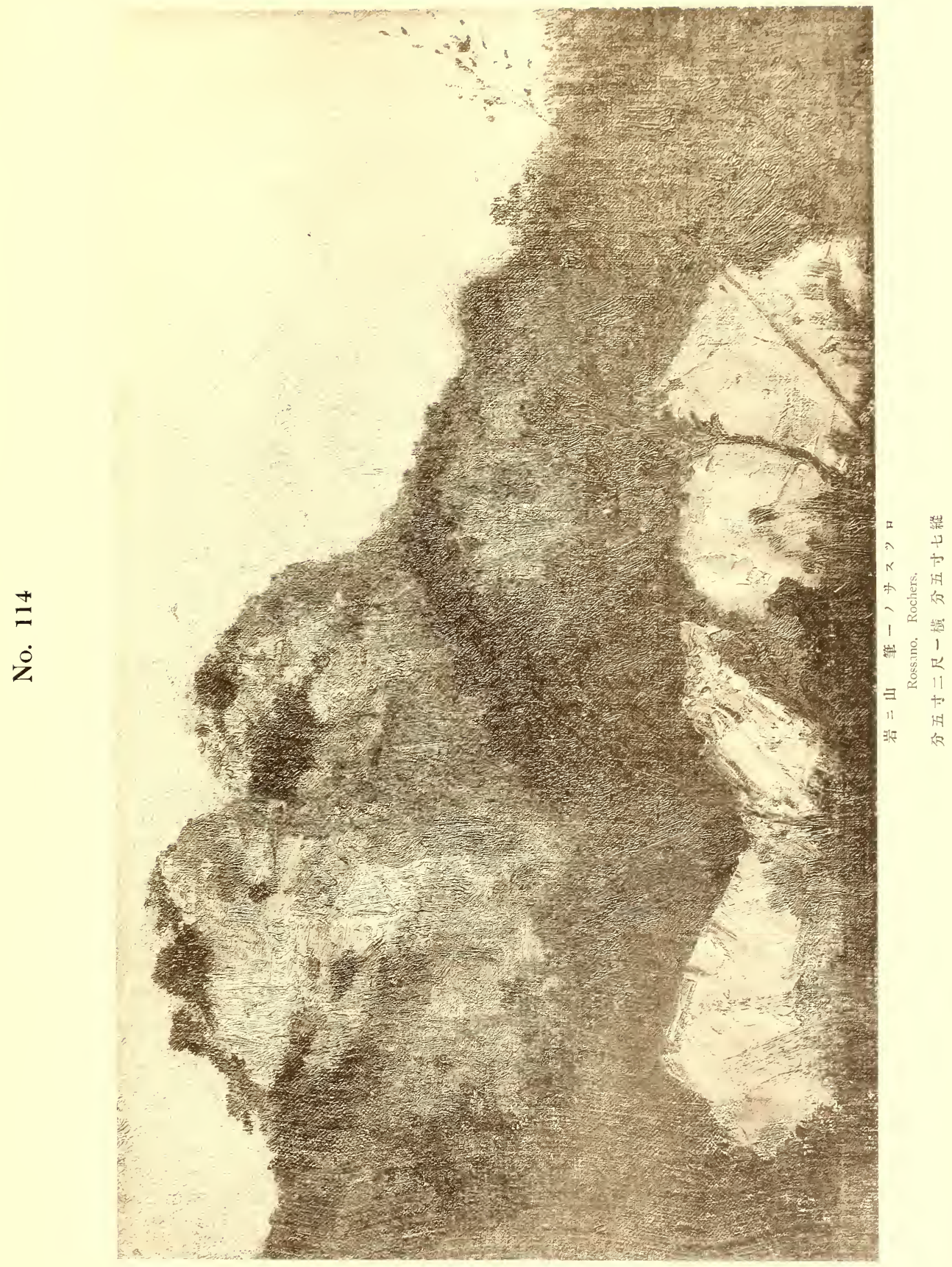


No. 114

E. ROSSANO

ITALIAN

Contemporary

ROCHERS

Height, 9 inches; length, 151/.2 inches

A PANEL-BACKed canvas sketch of masses of gray rocks, now outcropping in irregular form in the foreground, among sparse trees and the green herbage of a bold hillside, and again rising in tall peaks against the blue and gray of a summer sky.

Signed at the lower right, Rossano. 


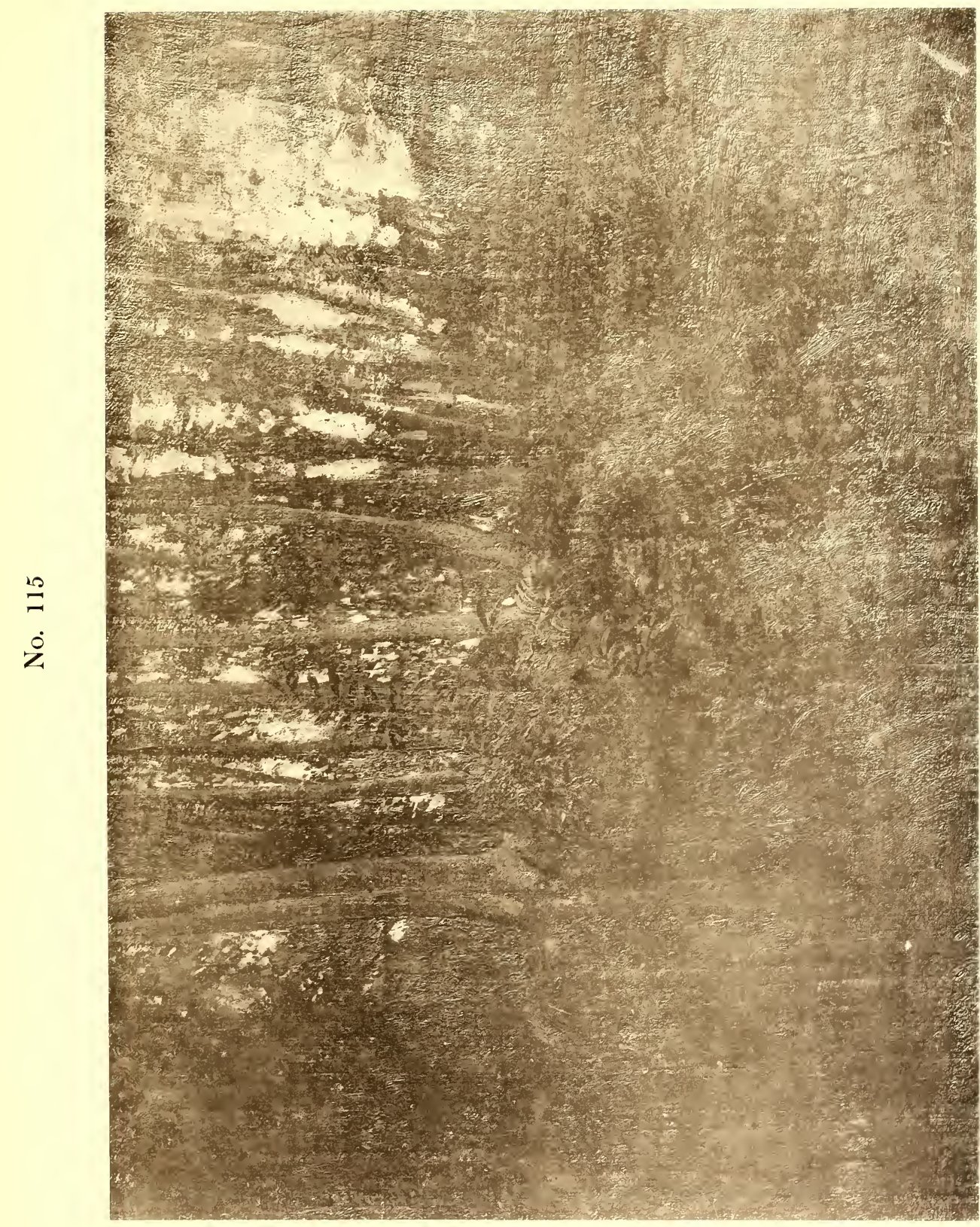

口 的

过

岸场

, 冚

\# 8 ?

些和 
No. 115

\section{E. ROSSANO}

ITALIAN

Contemporary

\section{INTERIEUR DU BOIS}

Height, 10 inches; length, 131/.2 inches

A Low, green-grown bank bordering a partly open space in a wood of slender trees rises at the left of the foreground. Of the nearer trees the lower trunks only are visible, against the green foliage of their more distant and lower-growing neighbors and patches of the sky.

Signed at the lower left, Rossano. 
No. 116

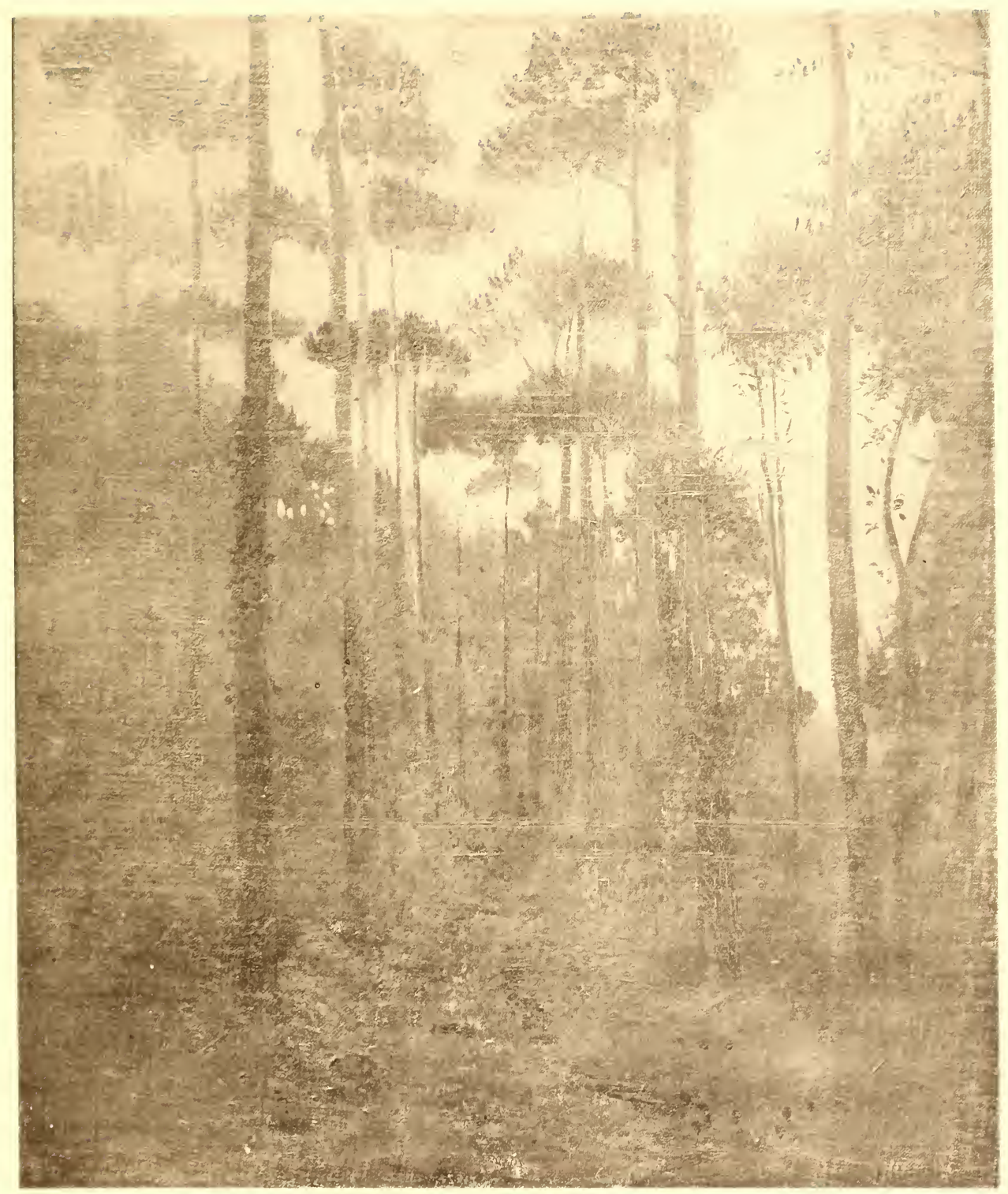

榤䇤ーノサッロ

Rossano. Bois

分五寸八慣分五尺一維 
No. 116

\section{E. ROSSANO}

ITALIAN

Contemporary

BOIS

$$
\text { Height, } 13 \text { inches; width, 101\%2 inches }
$$

A BRown and well-trodden footpath leads away from the spectator in a gentle curve, between lines of tall trees, in a more or less open wood. The footway is bordered by grasses and green undergrowth, which at the left creep up a neighboring hillside, the path continuing on the lower level.

Signed at the lower right, Rossano. 


\section{No. 117}

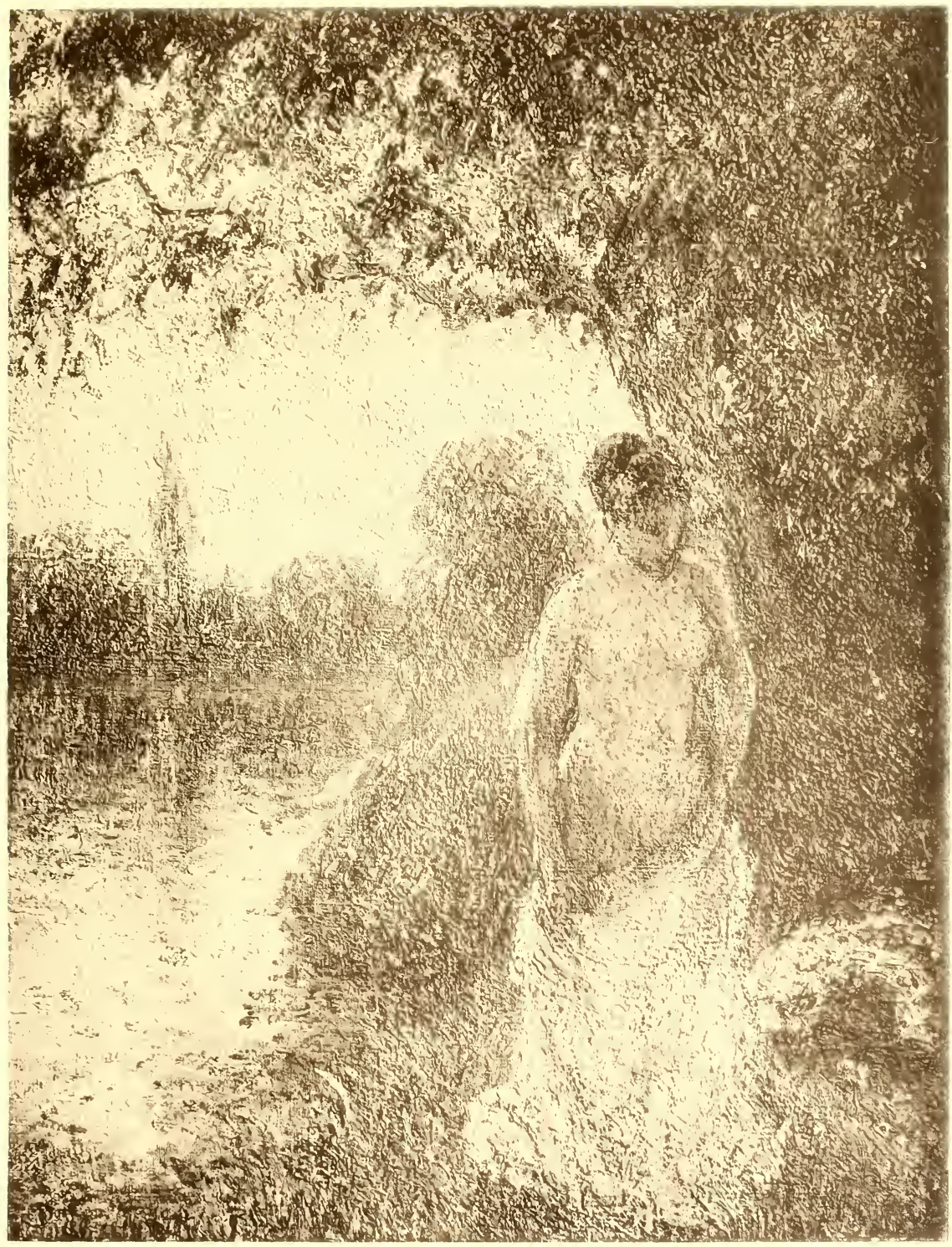

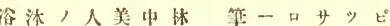

Pissaro. Baimneuse.

分五寸分模 寸一尺一锭
} 
No. 117

\section{CAMILLE PISSARRO}

FRENCH

1810-1903

\section{BAIGNEUSE}

Height, 131/2 inches; width, 101/2 inches

UNDER the shelter of a tree at a river bank a young woman has disrobed for a swim, her clothing being disposed upon a convenient rock or tree stump, excepting a single white garment from which she is just disengaging herself, as she stands half-nude in the grass. Beside and beyond her the stream and clouds are opalescent in the warm haze of a summer day.

Signed at the lower left, C. Pissarro, '95. 


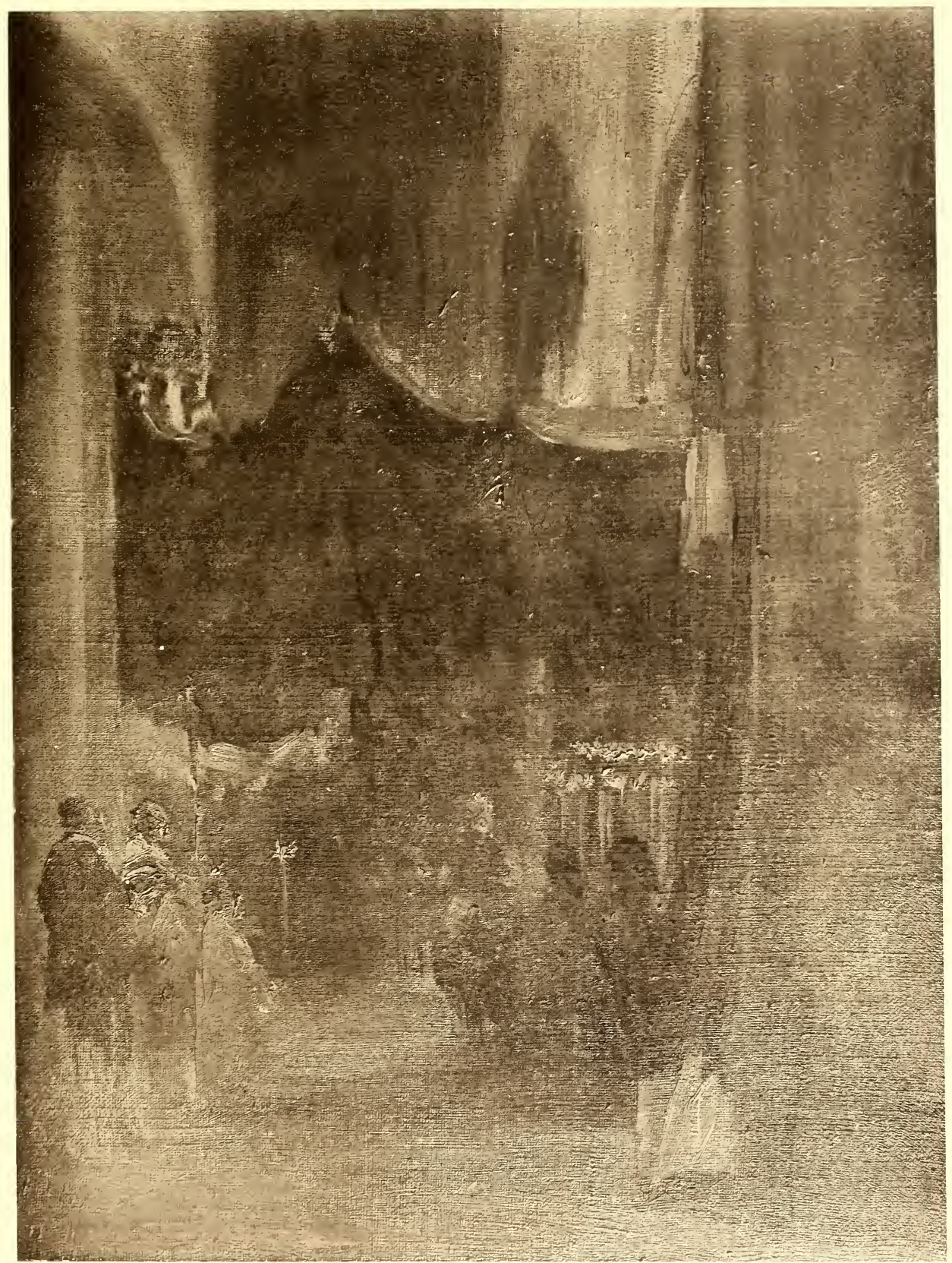

院寺ノホン亦一口䇠一レウトスホラ

Lapostelet. Interieur de la cathedrale de Ronon.

分五于八横寸一尺一积 
No. 118

\section{CHARLES IAPOSTOLET}

FRENCH

1824

\section{INTÉRIEUR DE LA CATIIEDRALE DE ROUEN \\ Height, 131\% inches; width, 101/2 inches}

A skeтch for the painter and amateur sensitive to the charm of "quality" in low tones. 'The dull brown and gray of the dim, misty interior of a corner of the vast cathedral are relieved-or the somberness is intensifiedby the high flashing candle lights of a service which is going on in the great Thirteenth century edifice; and figures are seen at the right and left of a central clear space that extends from the foreground to the obscure middle distance.

Inscribed and signed on the back, "Rouen, 97 fbre 1876, C. Lapostolet." 


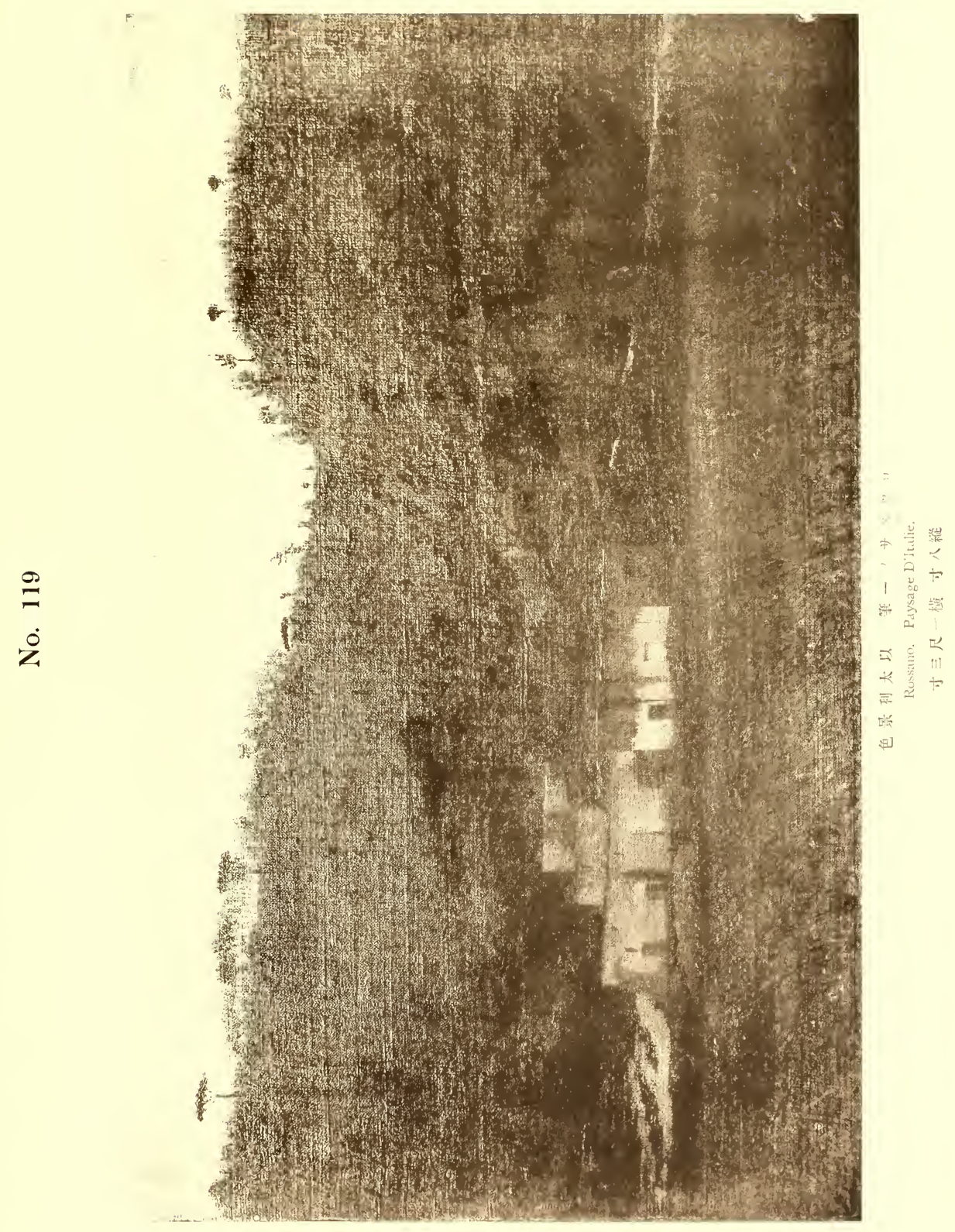


No. 119

\section{E. ROSSANO}

ITALIAN

Contemporary

\section{PAYSAGE D'ITALIE}

Height, 10 inches; length, 151\%2 inches

ON a flat foreground a group of squat, gray outbuildings stands backed against a mass of low hills, which rise presently in broken outline to tall, uneven, rounded crests, topped at the high skyline by short detached trees. The whole landscape a deep green and brown, sketched under a sky of light blue, with dull white clouds.

Signed at the lower right, Rossano. 


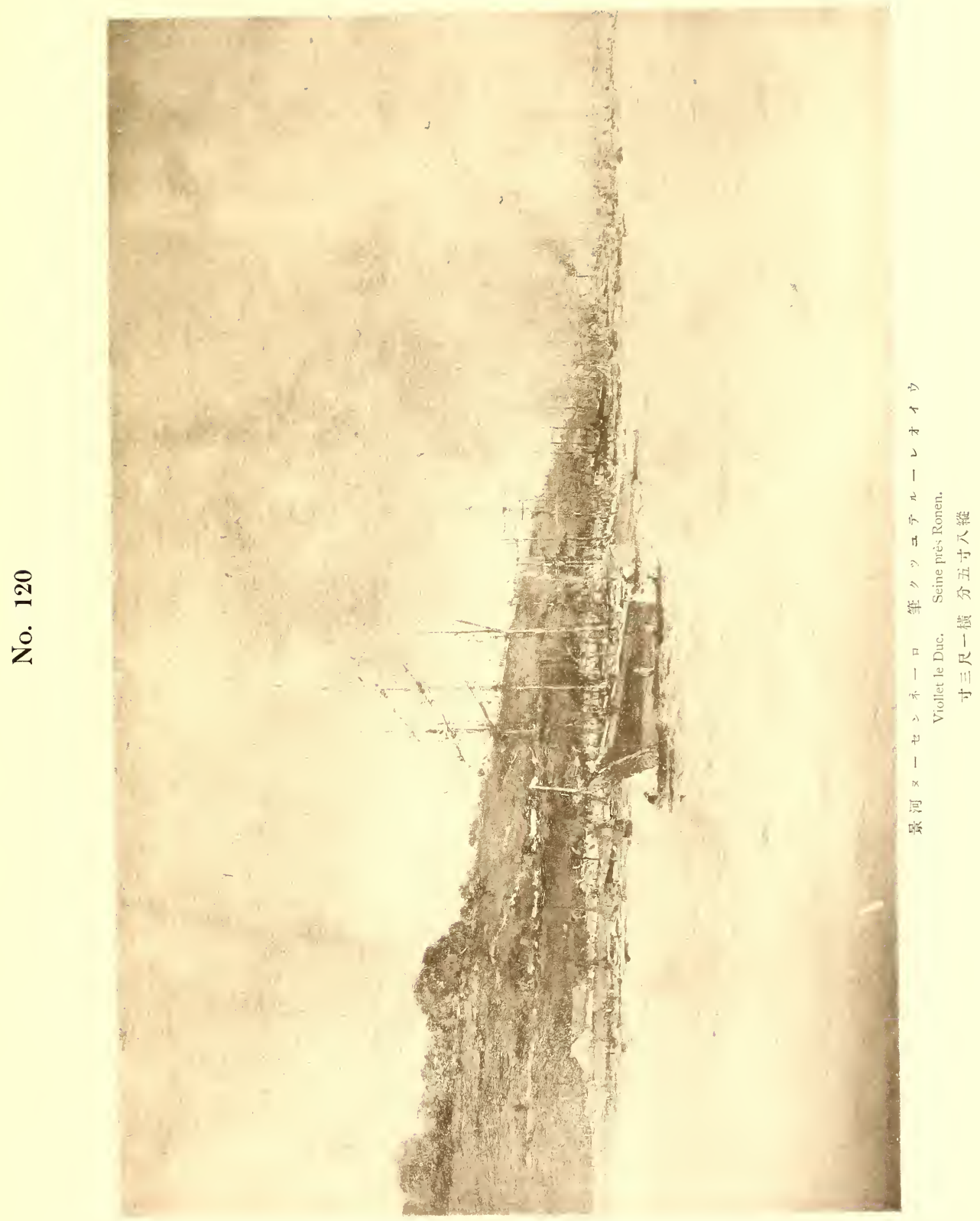


No. 120

VICTOR VIOLLE'T LE DUC

FRENCH

Contemporary

\section{LA SEINE PRES DE ROUEN}

Panel

Height, 101/2 inches; length, 16 inches

The broad river, of a silvery gray tone just tinged with reflections of the green bank at the left, and gently rippling in a summer breeze, is populous with the shipping of a busy port. 'The tall masts and yards of squareriggers rise against a blue sky flecked with bits of white cloud, the spars of the more distant ressels being blurred in smoke and a warm haze.

Signed at the lower left, V. Viollet le Duc. 


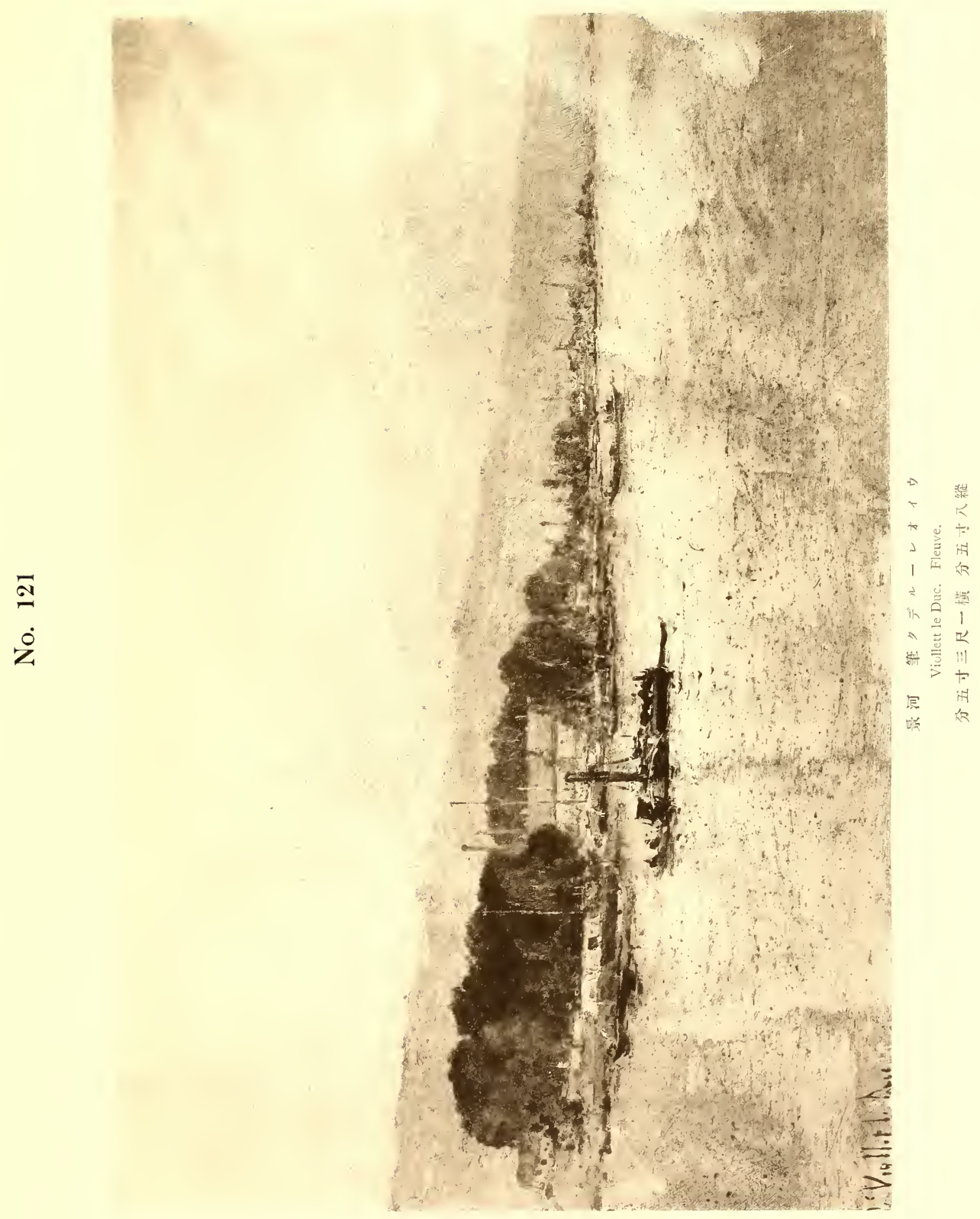


No. 121

VIC'TOR VIOLLE'T LE DUC

FRENCH

Contemporary

FLEUVE

$$
\text { Panel }
$$

Height, 101/2 inches; length, 16 inches

A вrodl river, very likely the Seine, sweeps from the right across the picture and forward, bearing numerous craft assembled along the margin at a small town thickly grown with bushy, shady, green trees. Beyond the flat borderland of the stream, the landscape extends in a high, even hillside, as far as the eye sees. The whole is bathed in warm, hazy light, under a moist and raporous sky.

Signed at the lower left, I. Viollet lo Duc. 


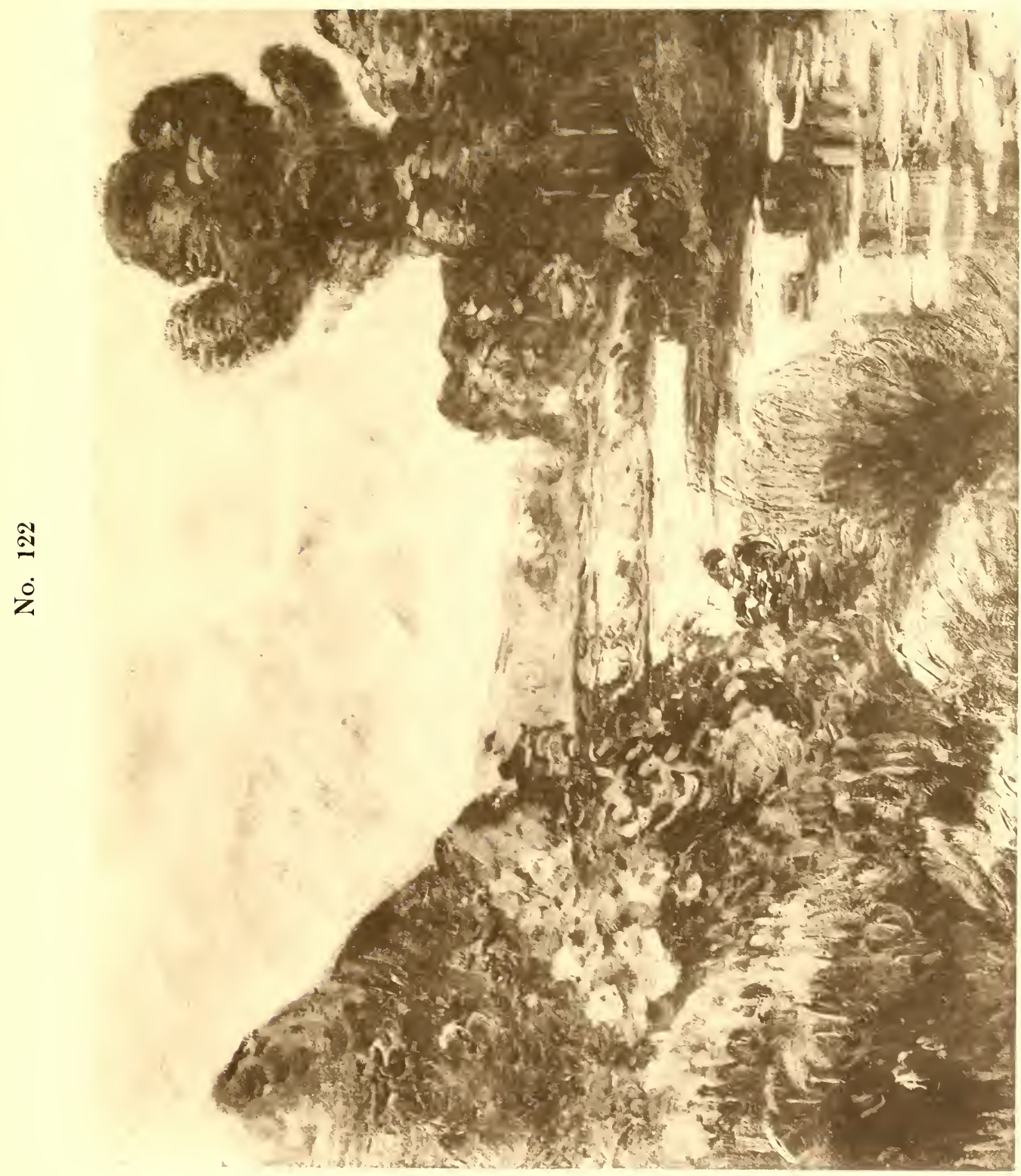

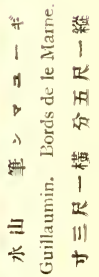


No. 122

\section{ARMAND GUILLAUMIN}

\section{FRENCH}

$1841-$

\section{BORDS DE LA MARNE}

$$
\text { Height, 121/2 inches; length, 151/2 inches }
$$

THE water of the river has in places the blue of starch, or of slate; again it takes the color of the reddish banks where the verdure has been washed away, or of the green slopes where the grasses and herbage still cling at the stream's edge. 'Trees green and blue rise at either side of the river, in regular and irregular masses, and the swirling clouds of a breezy day are tinged variously in sunset hues.

Signed at the lower left, Guillaumin. 


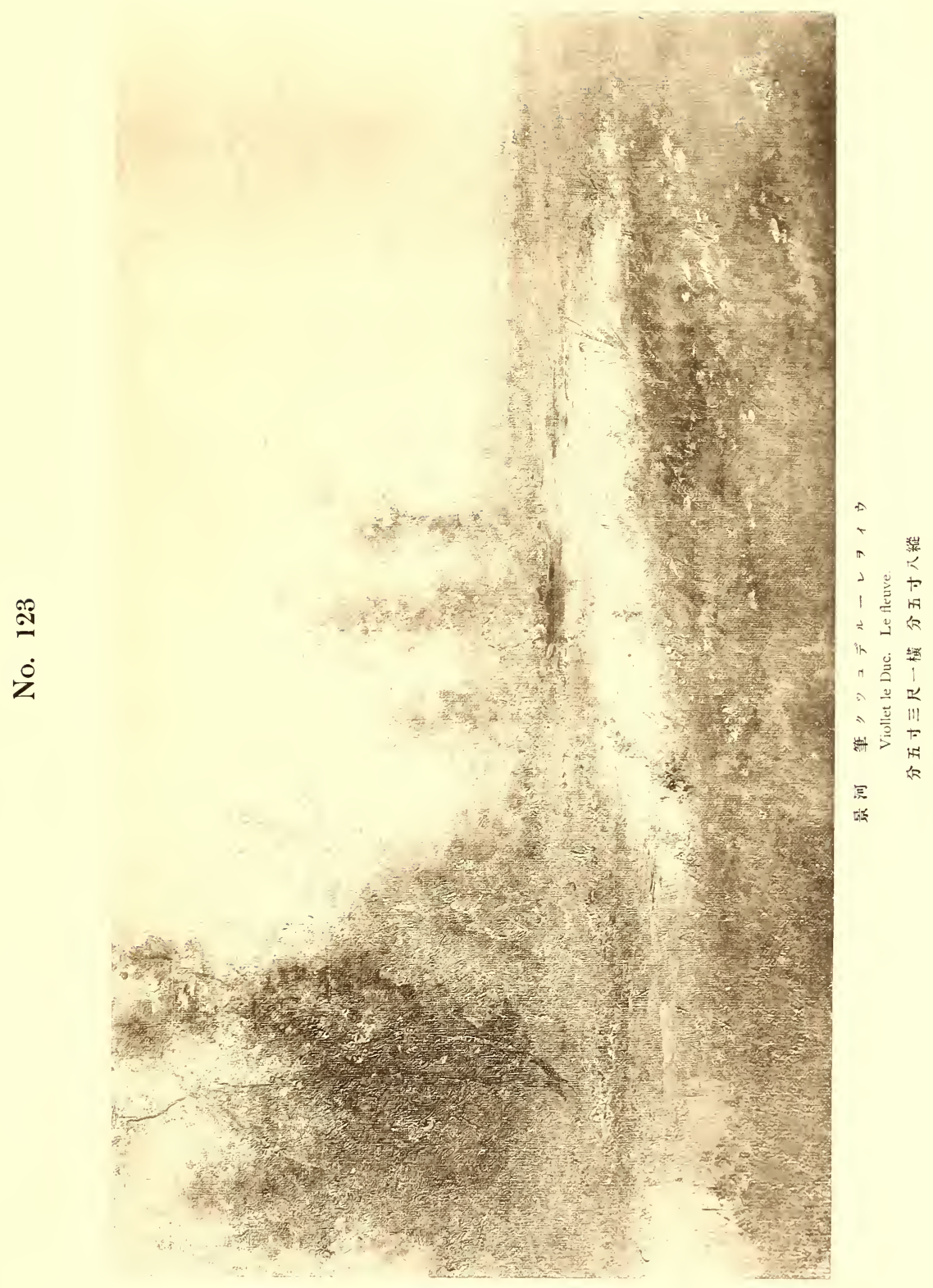


No. 12:3

\title{
VICTOR VIOLLET LE DUC FRENCH \\ Contemporary
}

\section{LA RIVIERE}

\author{
Height, 10 inches; length, 18 inches
}

A pastoral stream, silvery under a light gray sky, threads its way through a flat, green valley, its irregular boundaries indenting the land and projecting into the river as though but half-heartedly stemming or confining the gentle current. Grasses and blossoming wild flowers border it on the hither side. Across the stream a few slight, graceful trees are growing, here and there. At the foot of one group of the trees a boat with a figure or two in it is drawn up on the bank, and at the horizon there is a line of low hills.

Signed at the lower left, $\mathrm{r}$. Viollet le Duc. 

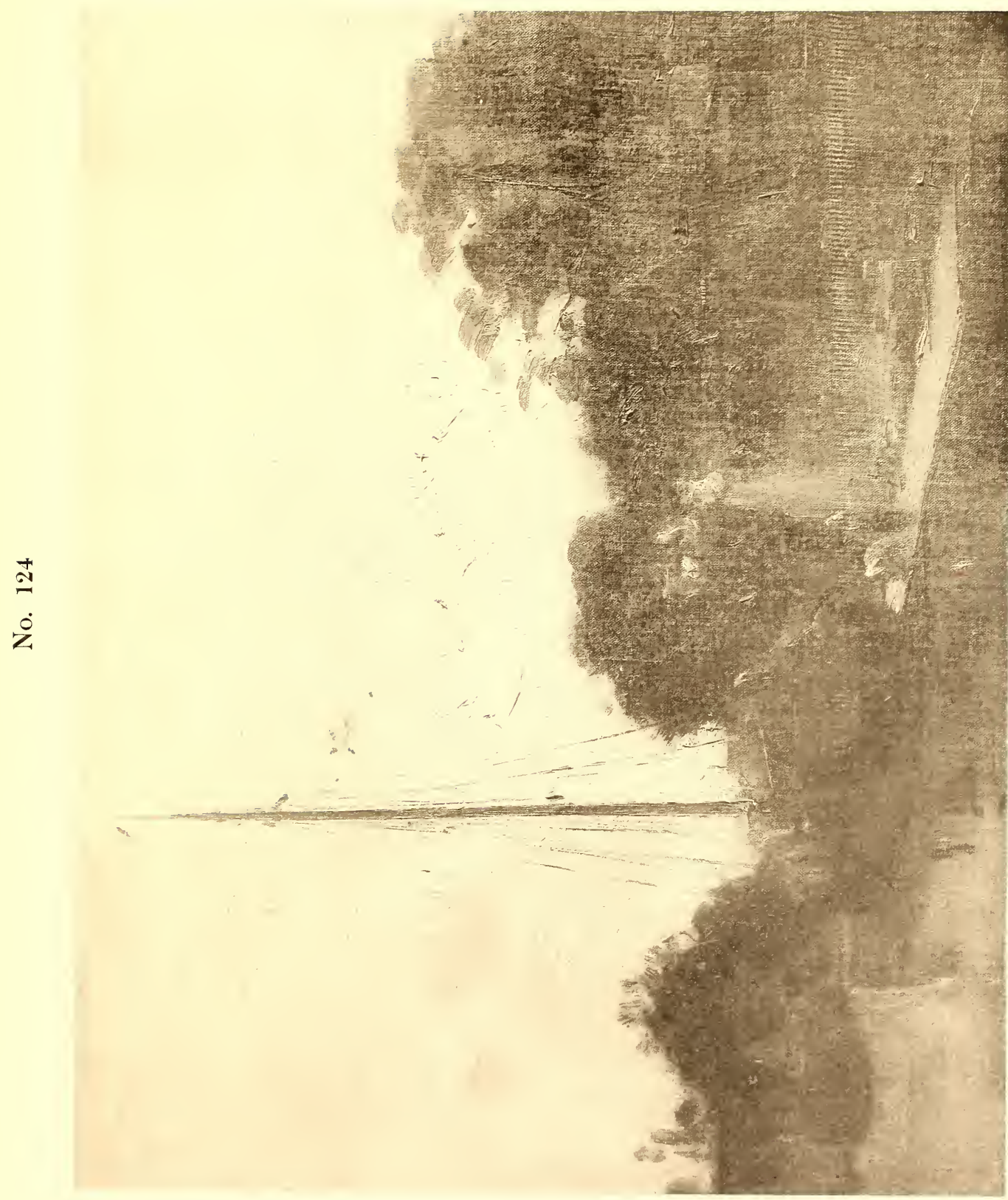
No. 124

\section{CHARLES LAPOSTOLET}

FRENCH

1824

\section{DORDRECH'T}

Height, 121/2 inches; length, 151/2 inches

A рuтch land- and water-scape in low key, giving a quiet picture of one phase of Low Country life. A river or canal enters the picture, forming the foreground, and on its waters floats a cargo boat with a single tall mast, the hull almost at the doorways of the buildings on the bank at the right. Here, figures are to be seen near the ship, and farther away along the stream are suggested more buildings of a town.

Signed on the back, "à Dordrecht, 1872, C. Lapostolet." 


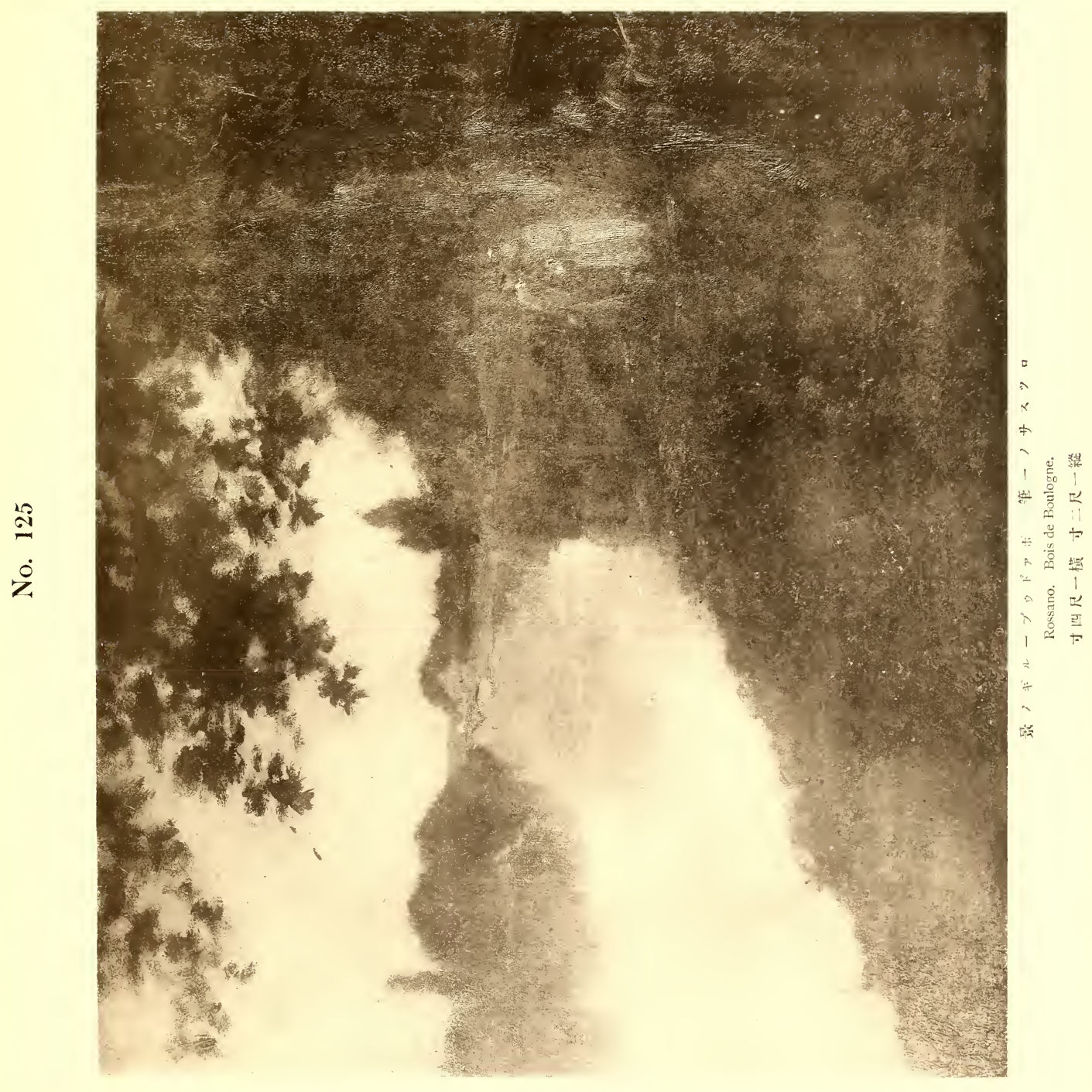


No. 12.5

\section{E. ROSSANO}

ITALIAN

Contemporary

\section{BOIS DU BOULOGNE}

Height, 141/2 inches; length, 161/2 inches

'The Seine is shown at a bend, or elbow, an extended stretch of the right bank along the famous park forming, with the river, the major part of the composition, only a wooded point of the farther or left bank being visible. The hither shore in its long sweep is grass-bordered, and the trees, some of them sending projecting branches over the water, do not grow so near to the stream but that plenty of promenade room is left. Here, along the grass, a man and woman are approaching, arm in arm. In the distance one sees an arch or two of a bridge.

Signed at the lower left, Rossano. 
No. 126

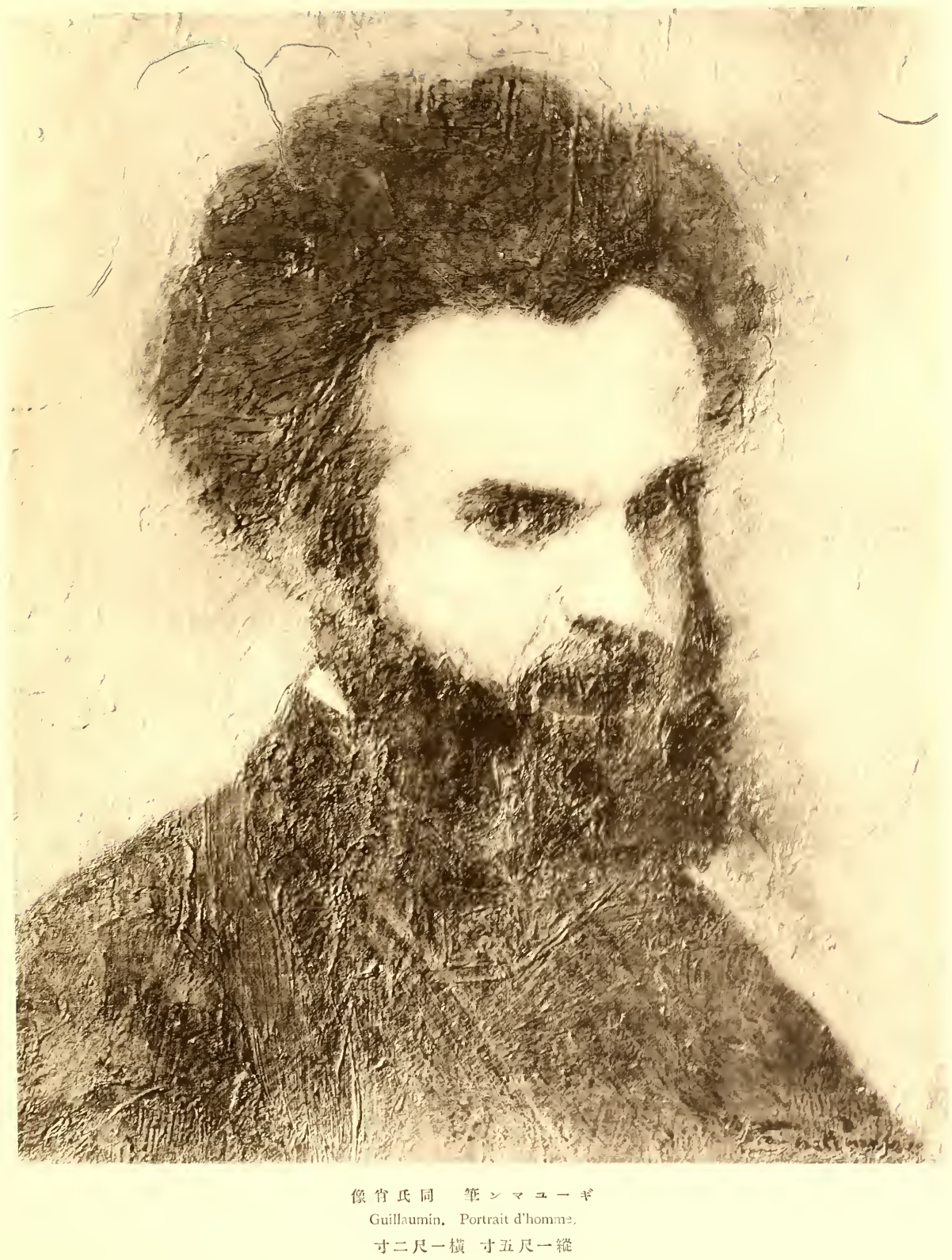


No. 126

\section{ARMAND GUILLAUMIN \\ FRENCH}

1841-

PORTRAIT D'HOMME

Height, 17 inches; width, 141/2 inches

A frenchman with dark, curly hair and a full beard is depicted, head and shoulders, in a thoughtful attitude. IIe faces the right, three-quarters front, and inclines his head slightly downward. He has a wide, high, bulging forehead, and his eyes are deep-set and contemplative.

Signed at the lower right, Guillaumin. 


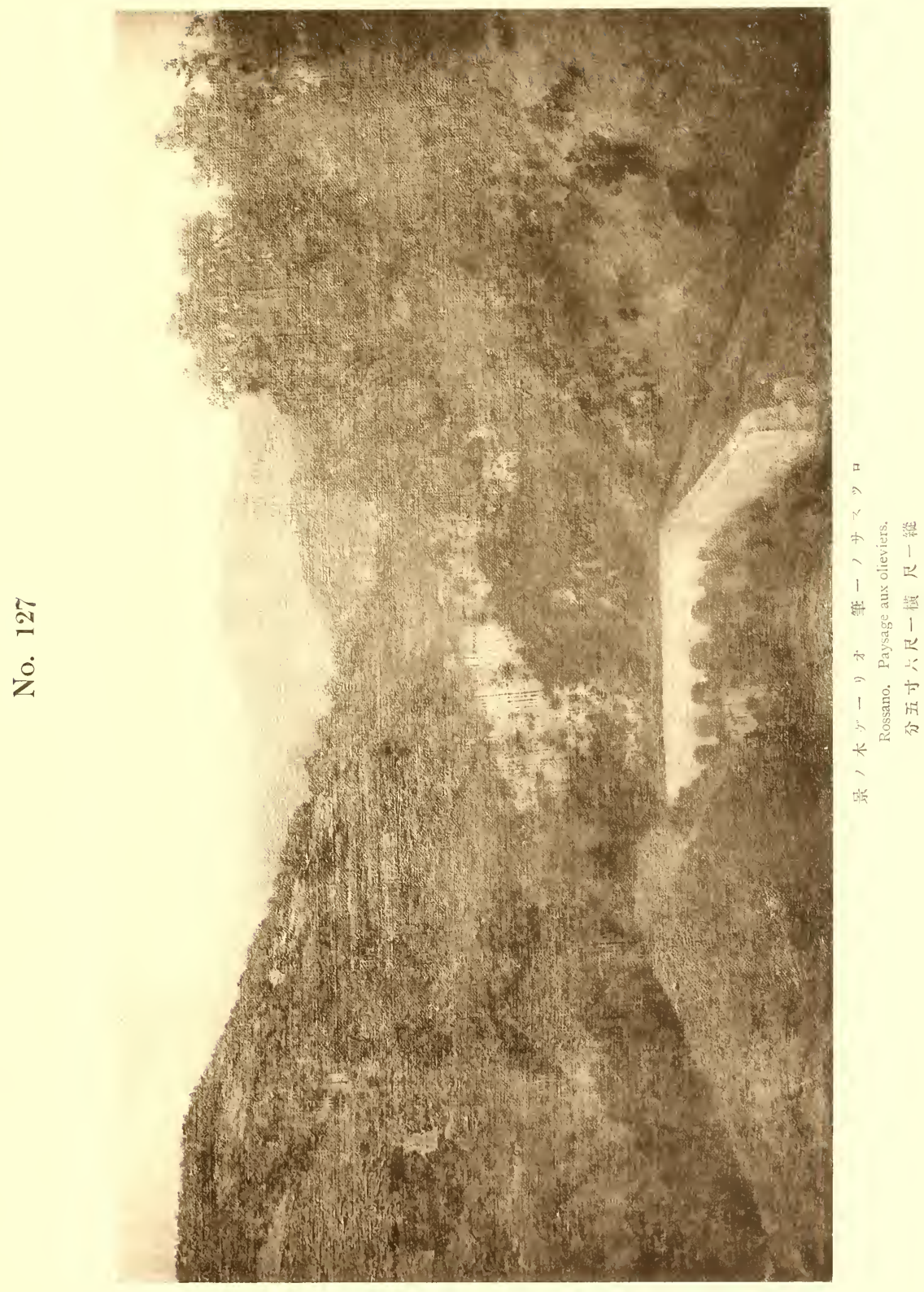


No. 127

\section{E. ROSSANO}

ITALIAN

Contemporary

\section{PAYSAGE AUX OLIVIERS}

Height, 12 inches; length, 20 inches

On the slope of a green hill which enters the picture from the right, a number of olive trees lean toward the valley to which the decline swiftly descends, only to rise again as abruptly, and to a greater height, at the left,- the deep cleft being filled with trees. A road in the foreground is bordered by a masonry wall, which, turning to the left, becomes a viaduct, pierced by archways, and carrying the road over the valley. And in the distance are more rolling hills.

Signed at the lower right, Rossano. 


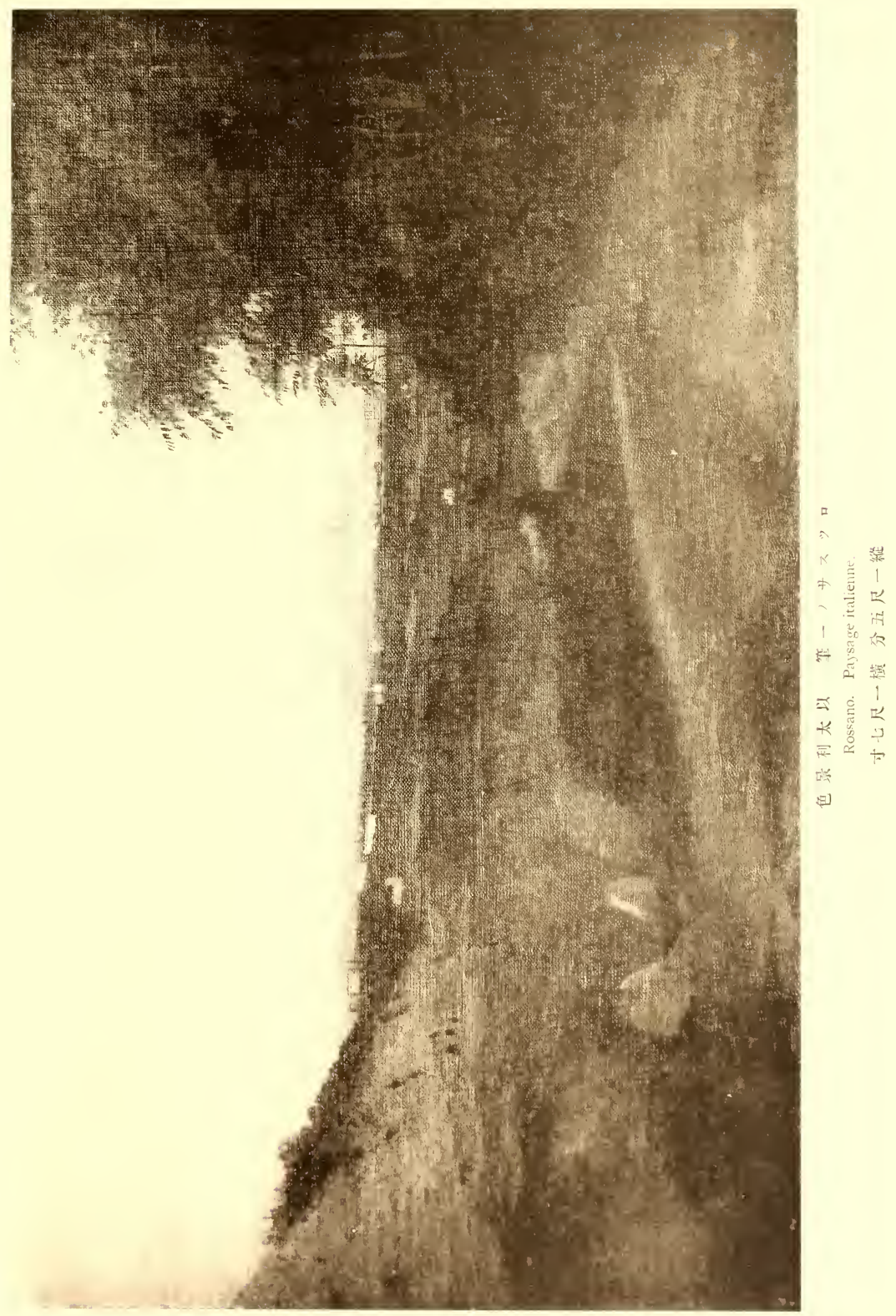


No. 128

\section{E. ROSSANO}

\section{ITALIAN}

Contemporary

\section{PAYSAGE ITALIEN}

Height, 13 inches; length, 201/4 inches

Irregular hills rise in the distance, across an uneven valley dotted with buildings. In the foreground a road winds through a pass among low hills, and beside it at the foot of a broken wall two children are seated-a boy and a girl-on the grass. A quiet landscape with an effect of remoteness, which is scarcely modified by the presence of the children.

Signed at the lower right, Rossano. 


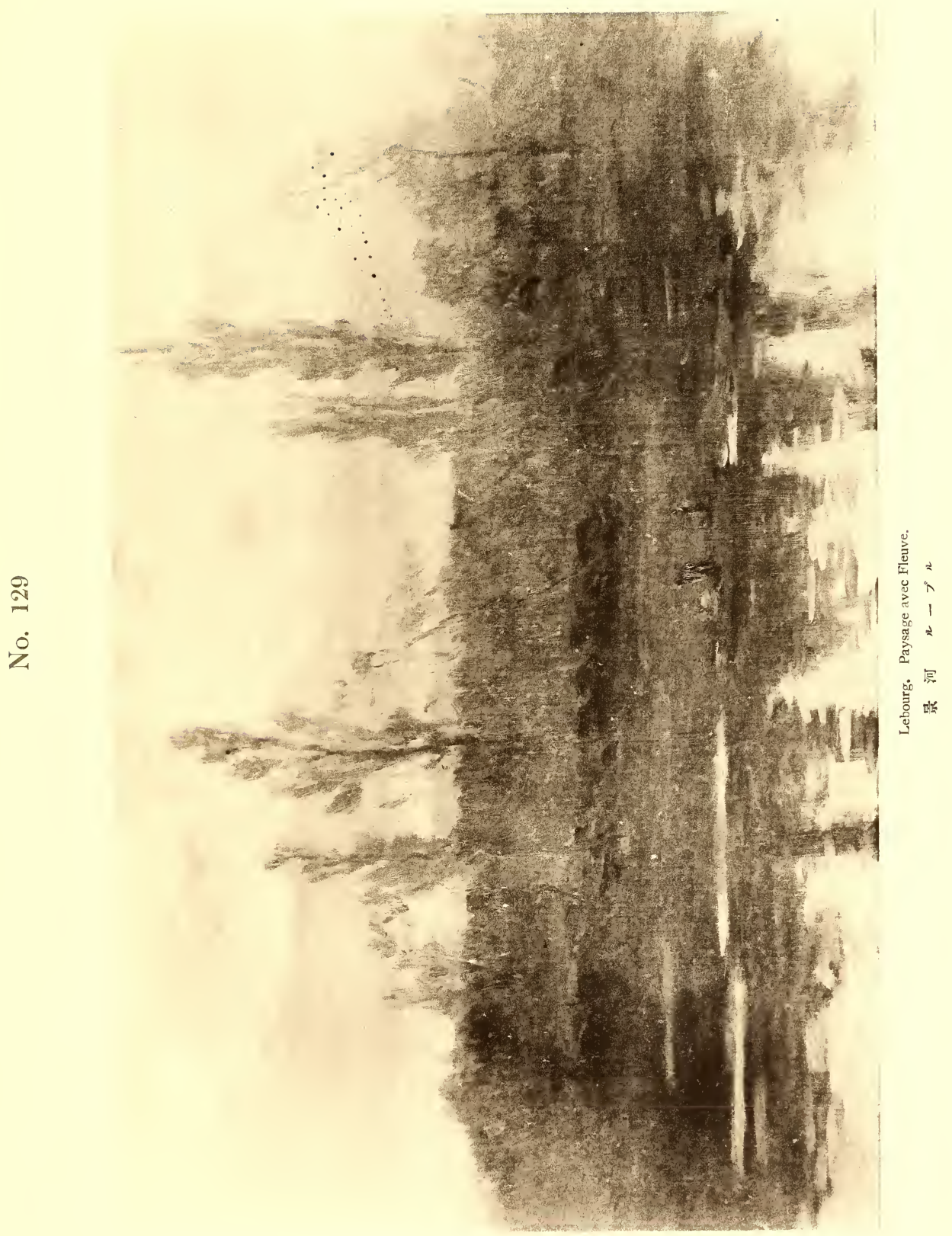


No. 129

ALBERT LEBOURG

FRENCH

1849-

\section{PAYSAGE AVEC FLEUVE}

Height, 141/2 inches; length, 24 inches

A sLuggish river passes across the canvas, its brighter foreground darkening toward the middle distance under the shadows of the farther bank and its trees. Behind the trees, over the last blue hilltop, the sky is alight, and peopled with purple clouds. The foliage of the far bank has the hues of Autumn, and on the quiet water of the river float two rowboats, carrying people.

Signed at the lower left, A. Lebourg, 1873. 


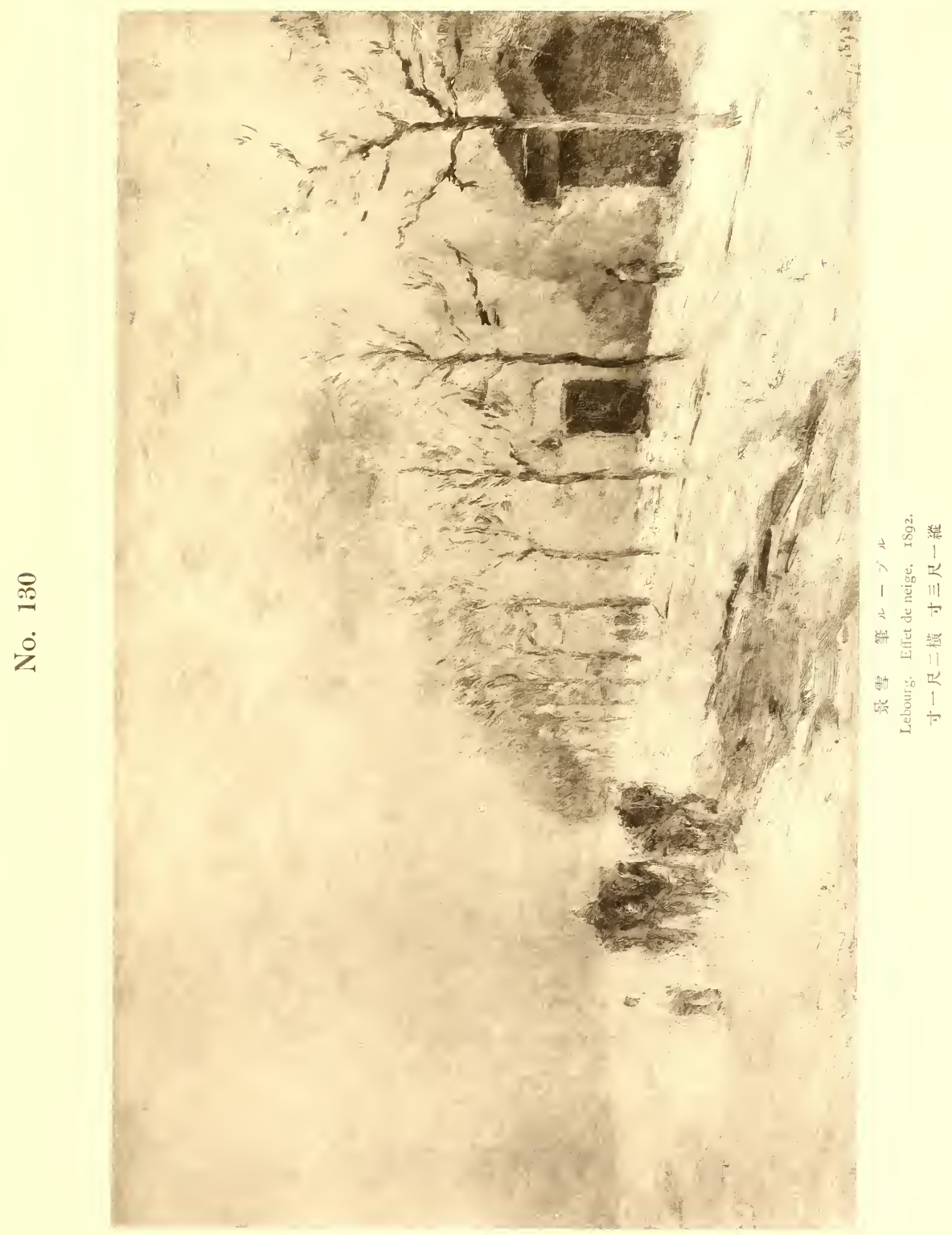


No. 130

\section{ALBER'T LEBOLRG}

FRENCH

1849-

\section{EFFET DE NEIGE}

$$
\text { Height, 15:34 inches; length, } 251 \text {-2 inches }
$$

A Rare, snowy day of winter in Paris, the riew extending along a boulevard near the river. The air is seemingly charged with fine, drifting snow, though the sky overhead has almost cleared, and the sun has struggled through the vaporous curtain near the horizon sufficiently to throw cool, green shadows orer the whitened roadway. 'Two great white horses, laboring tandem, drag a cart forward, and an occasional pedestrian is seen on the sidewalks.

Signed at the lower right, Albert Lcbourg, 1899. Inscribed on the back, "Boulezard au bord de la Scine, azec environs de Paris. Paysage d'hicer." 
No. 131

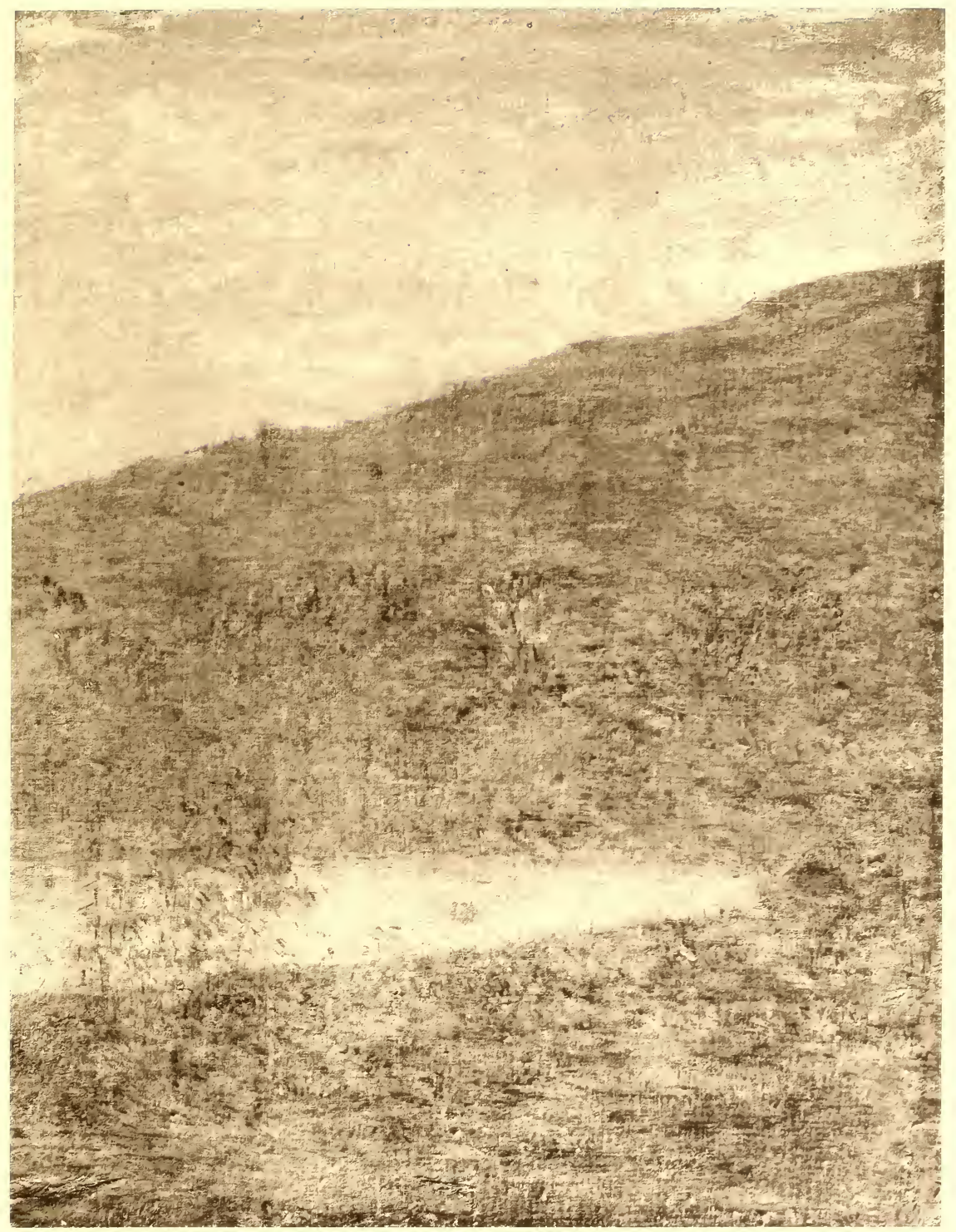

油，中山等コシーラプ

I lache, Étang dans les montagnes.

小三尺一横打比一縒 
No. 131

\section{PHILIPPE CHARLES BLACHE}

FRENCH

Deceased

\section{ETANG DANS LES MONTAGNES}

Height, 201/2 inches; width, 151/2 inches

ThLL mountains rise one beyond another to a high skyline or horizon, their crests under low-hanging, pinktinged clouds. The near slope of the nearest mountain, covered with verdure and trees, descends to a pond, grassbordered, in the foreground, where the water mirrors the colors of near-by trees and the hues of the distant clouds.

Signed at the lower right, dated 1892 and $189 \%$, and numbered 52. 


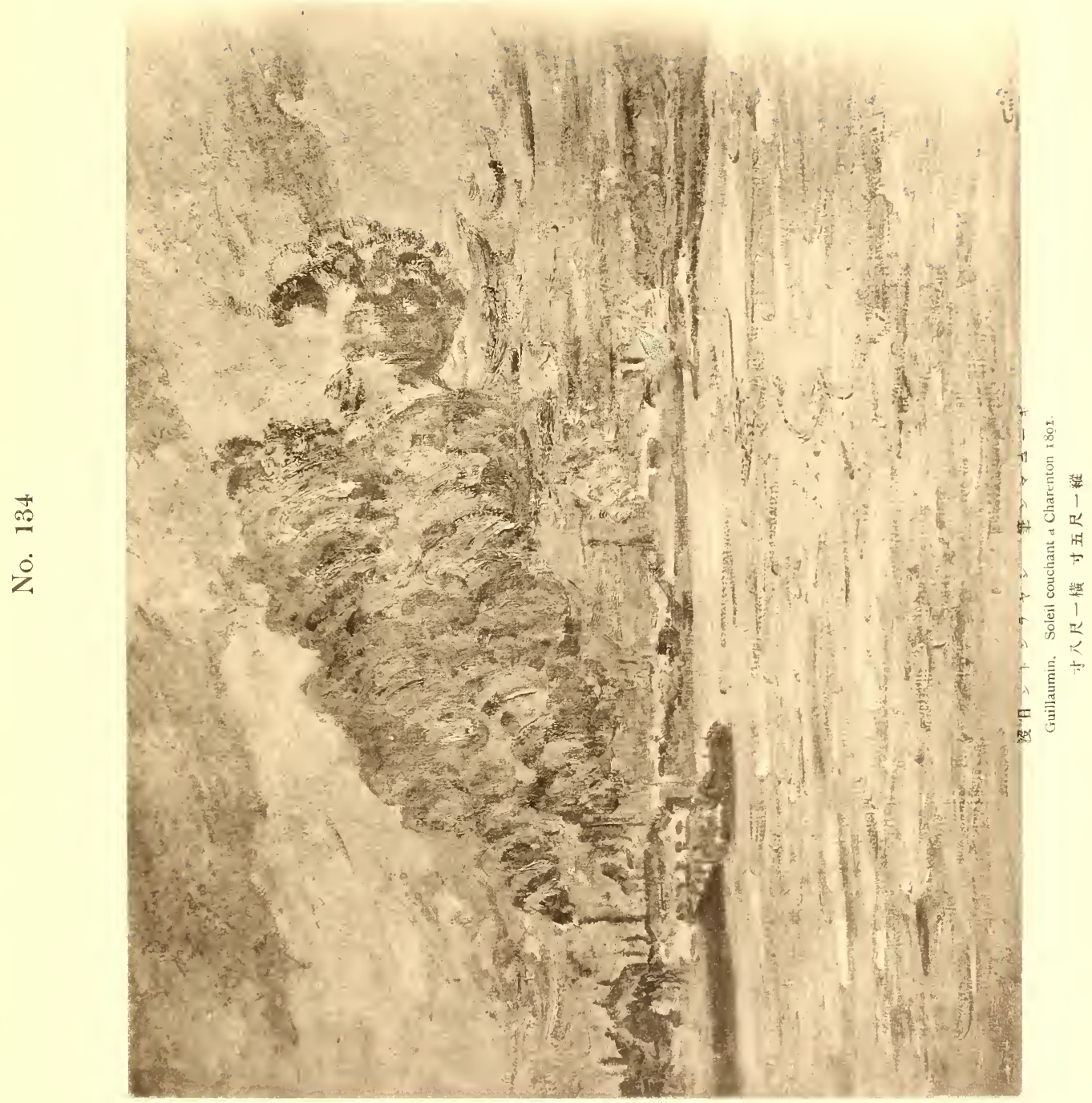


No. 134

\section{ARMAND GUILLAUMIN \\ FRENCH \\ $18+1$ -}

SOLEIL COUCHANT A CHARENTON, JUIN, 1891

Height, 18 inches; length, 211/4 inches

THe Seine and the sky are aflame with the chromatic brilliance of sunset, as the spectator looks from Charenton westerly across Paris, with familiar monuments of the city rising in distant silhouette against the burning heavens. At the right is a green bank of the curving river. At the left, buildings line the shore, and above them the gonfalon of industry - a pall of swirling smoke sent from numerous chimneys - streams out over the peaceful river and mounts toward the effulgent sky.

Signed at the lower right, Guillaumin, ‘91.

The title as given appears on the back. 
No. 135

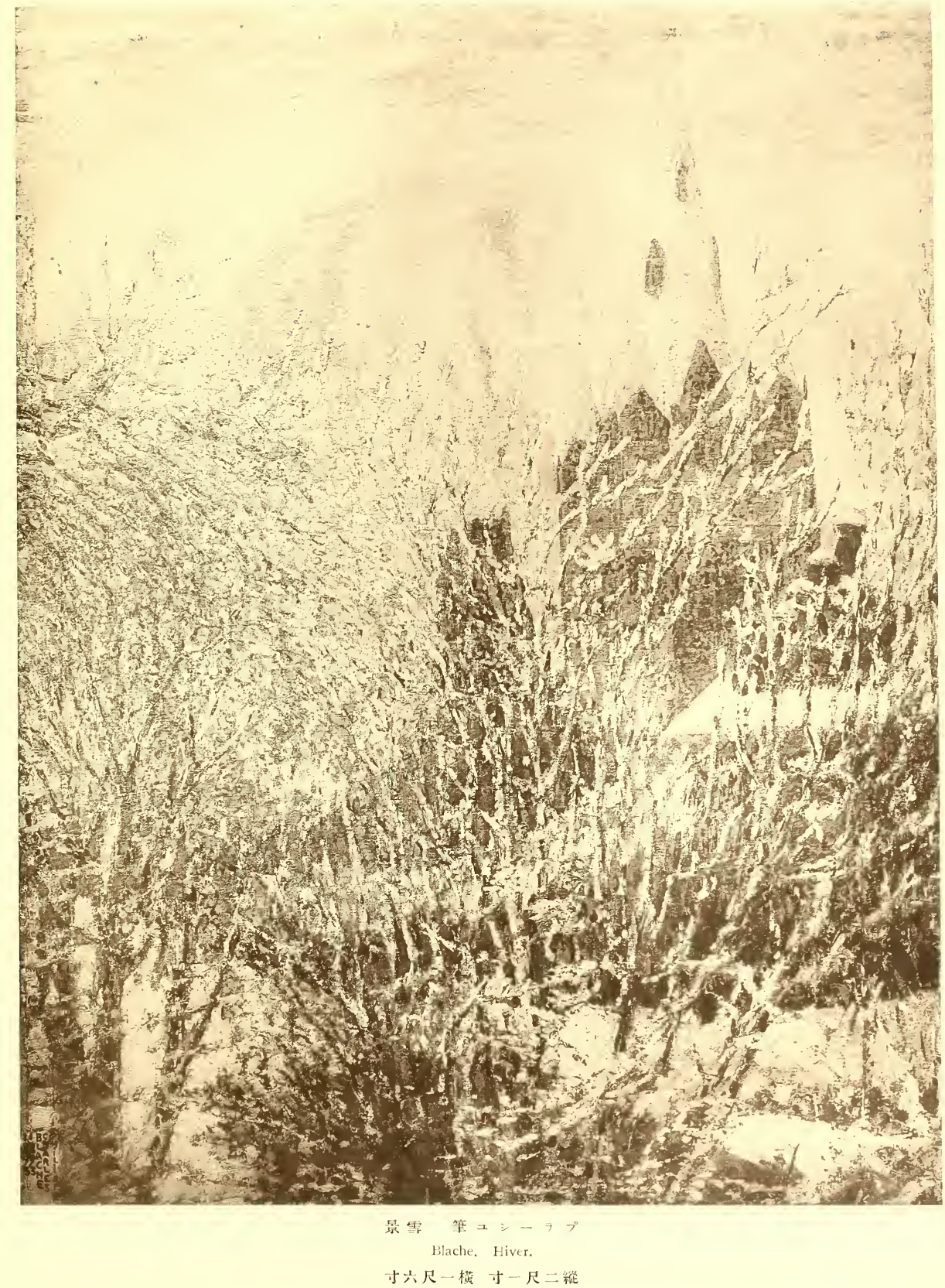


No. 13.5

\title{
PHILIPPE CIARLES BLACIIE
}

FRENCH

Deceased

\section{HIVER}

\author{
Height, 2.5 inches; width, 19 inches
}

THE outlook or point of view is from a high window, whence one sees through and over some treetops of the barren season-flecked or burdened with snow-to the mass and spire of a church in the middle distance, and beyond to what seems to be a strangely-shaped mountain top, glowing yellow under a blue sky in the late rays of the setting sum. 'These are the ancient steeple of Grenoble and the "Casque de Néron," or "Nero's Hehmet," which together exercised such a fascination on this artist that he studied them at all times of the year and in varied weather and lights. A similar composition, in a different seasonal aspect, appears among the pastels of this collection in "Springtime"-No. 89 of the group of pastels-and the church tower in Winter is seen again, alone, in "Snow," No. 90 of the same group.

Signed at the lower left, dated 1893 and 189.5, and numbercd 5. 


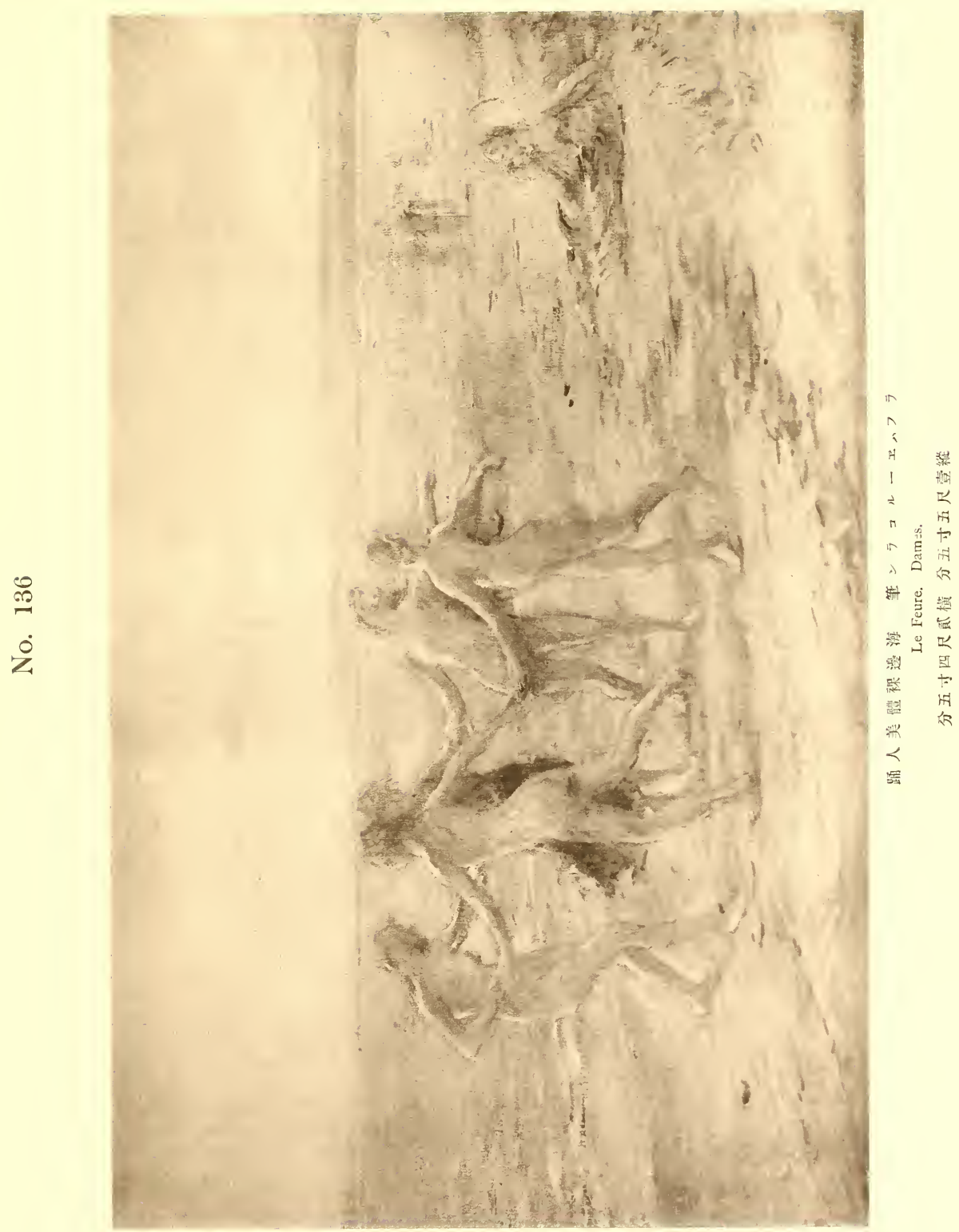


No. 136

\section{LOUIS JOSEPH RAPHAEL COLLIN \\ FRENCH}

18.50-

\section{D.NSES SUR LA PLAGE}

Height, 181\%_ inches; length 99 inches

This picture of unclad and unfettered nymphs at merriment on the beach was the preliminary sketch for the large painting of the same title which appears as No. 16.5 of this collection. One of the fire dancing figures wears a slight drapery. 'Three have allowed their hair to fall over their shoulders. The gray-brown sands and the bluegreen water are bounded in the distance by blue hills, and besides some nearer figures lying on the beach and not taking part in the dance, others appear a little way off, bathing in the shallows, these bathers being omitted from the larger canras.

Signed at the lower right, R. Collin. 


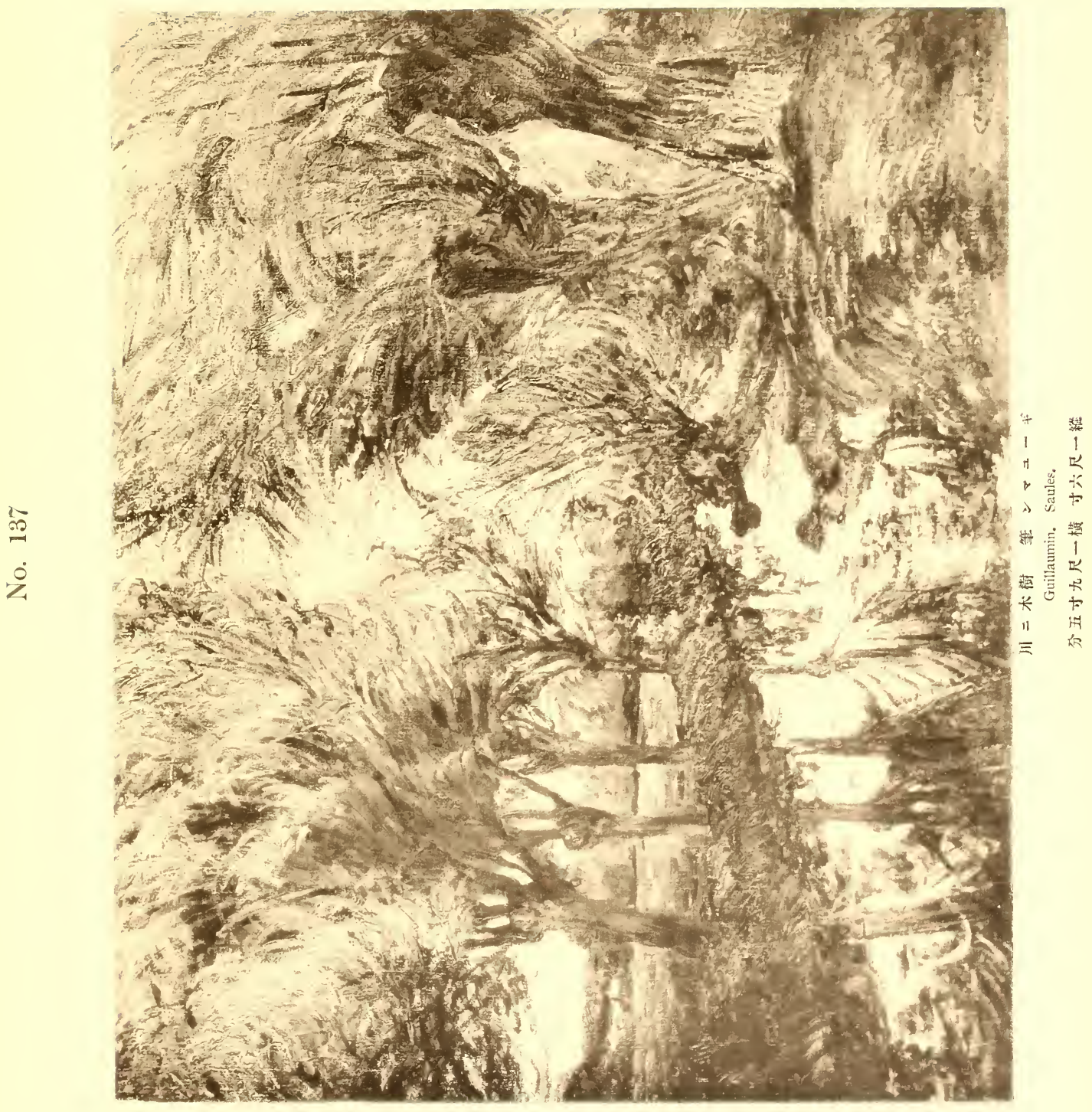


No. 137

\section{ARMAND GUILLAUMIN}

TRENCH

$18+1-$

\section{SAULES}

Height, 193/4 inches; length, 2t inches

A nARrow river bisecting the picture, its further reaches lost in its winding course among the trees, is bordered near at hand on either green bank by pollarded willows. The stunted trunks at the right are thick and old, and one leans far over the river. The younger pollards on the other bank at the left are mirrored in the stream in the foreground.

Signed at the lower right, Guillaumin. 


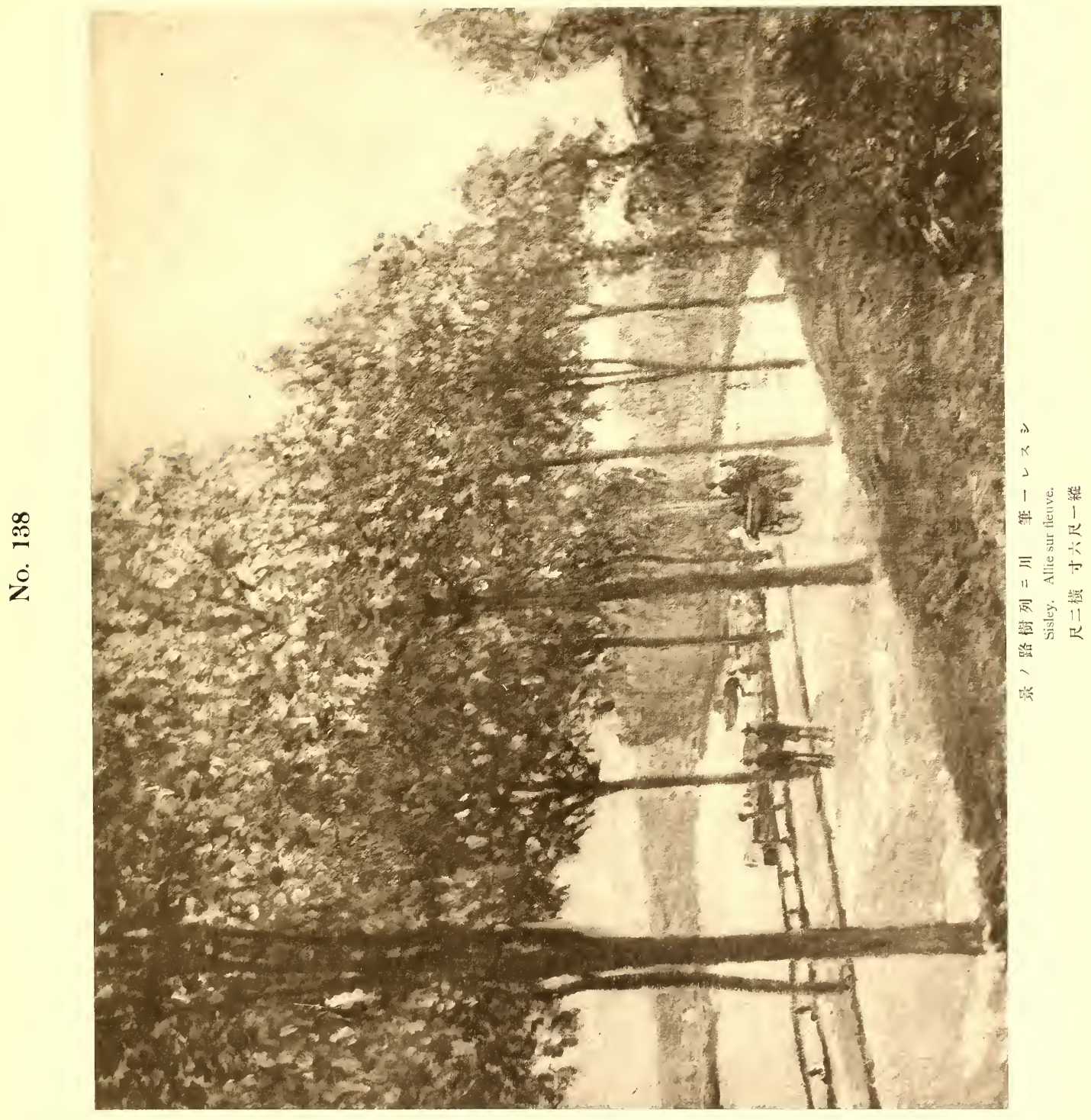


No. 138

\section{ALFRED SISLEY}

FRENCH

1840-1899

\section{IILEEE SUR FLEUVE}

Height, 19 inches; length, 231/2 inches

Ax arenue bordered by trees on either side winds along the margin of a broad river, which curves to the left as it passes toward the background, where it is crossed by a stone bridge of many arches. In the shaded roadway figures are seen promenading, and others in an open carriage. The herbage by the roadside is lush and green; the water of the river a light, greenish-blue. A landscape typical of France.

Signed at the lower right, Sisley, "T8. 


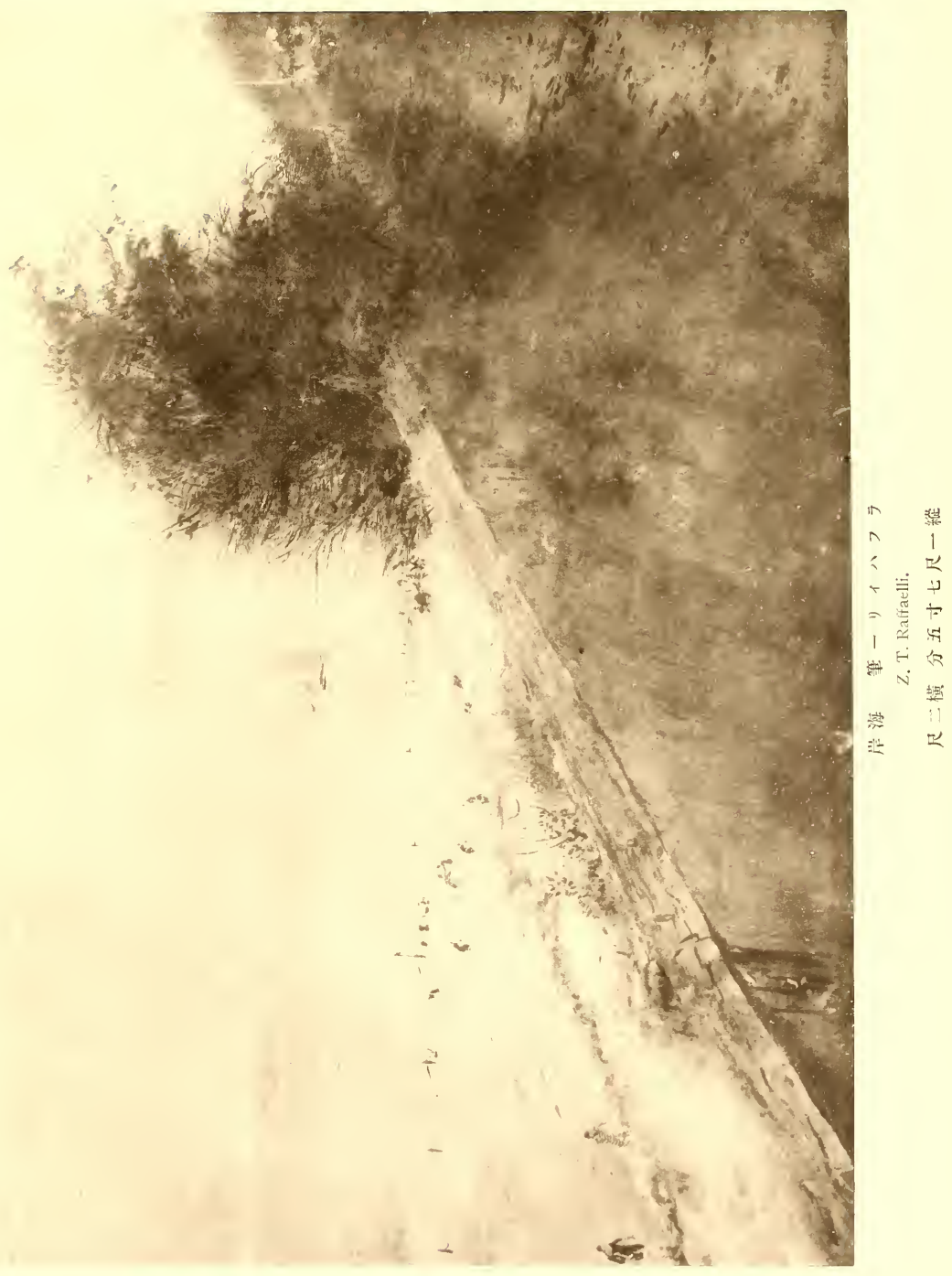


No. 139

\section{JEAN FRANCOIS RAFFAELLI \\ FRENCH}

1850-

\section{B.IIN DE MER, TREPORT}

Parel

Height, 21 inches; length, 24 inches

IT is a misty day on the Channel, with little wind. Fleecy clouds all but obscure the blue of the summer sky. Offshore a sailing ship or two moves lazily. In the shallows within the life lines of the bathing beach at Tréport bathers are busy, dipping or frolicking, their colored garments adding brightness to the scene, as the lazy wavelets roll up. Along the beach are other people, and boats, and the bathing tents; and high above them a great bluff of the foreground gives a stretch of sober green from which to overlook the prospect below. On the bluff, railed in and assembled under a weakly fluttering tricolor, less eager sojourners by the sea lean out and watch the bathers in the water below.

Signed at the lower right, J.F. Raffaelli.

On the back of the pancl is the following inscription:

"Bain de mer, Le Tréport, France.

"Chez Mr. Raffaclli (Jean François), "né à Paris 1850,

"dans son nouvelle

"atelier, de la rue de

"Courcelles, 202, Paris,

"Samedi, 26 Mars, 1892.

(Signed) "T. Hayashi." 


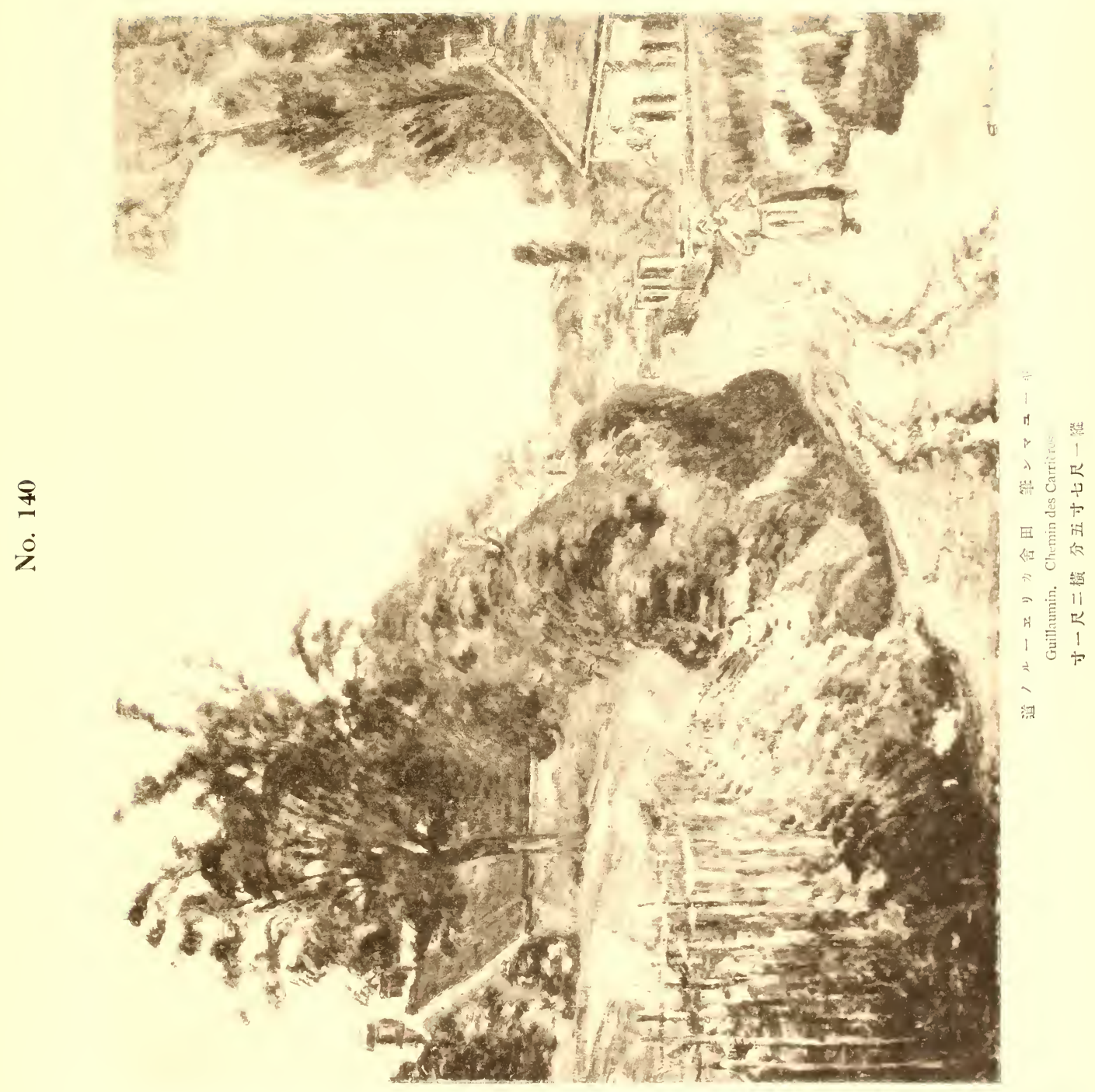


No. 140

ARMAND GUIILAUMIN

FRENCH

1841 -

\section{CIIEMIN DES CARRIETES}

Height, 21 inches; length, 25 inches

Through a landscape where herbage and trees bespeak Nature's bounty, and substantial cottages betoken the comfortable dwelling place of man, a narrow, steep and sandy wagon road, no doubt leading from neighboring quarries, cuts along the side of a prolific ledge green with trees, grasses and bushes. A single wagon track has rutted its surface, through many passings, and a strong peasant woman is threading her way beside it, a pitchfork over her shoulder.

Signed at the lower right, Guillaumin.

On the back is written, "à Milegard, Juin, 1891." 


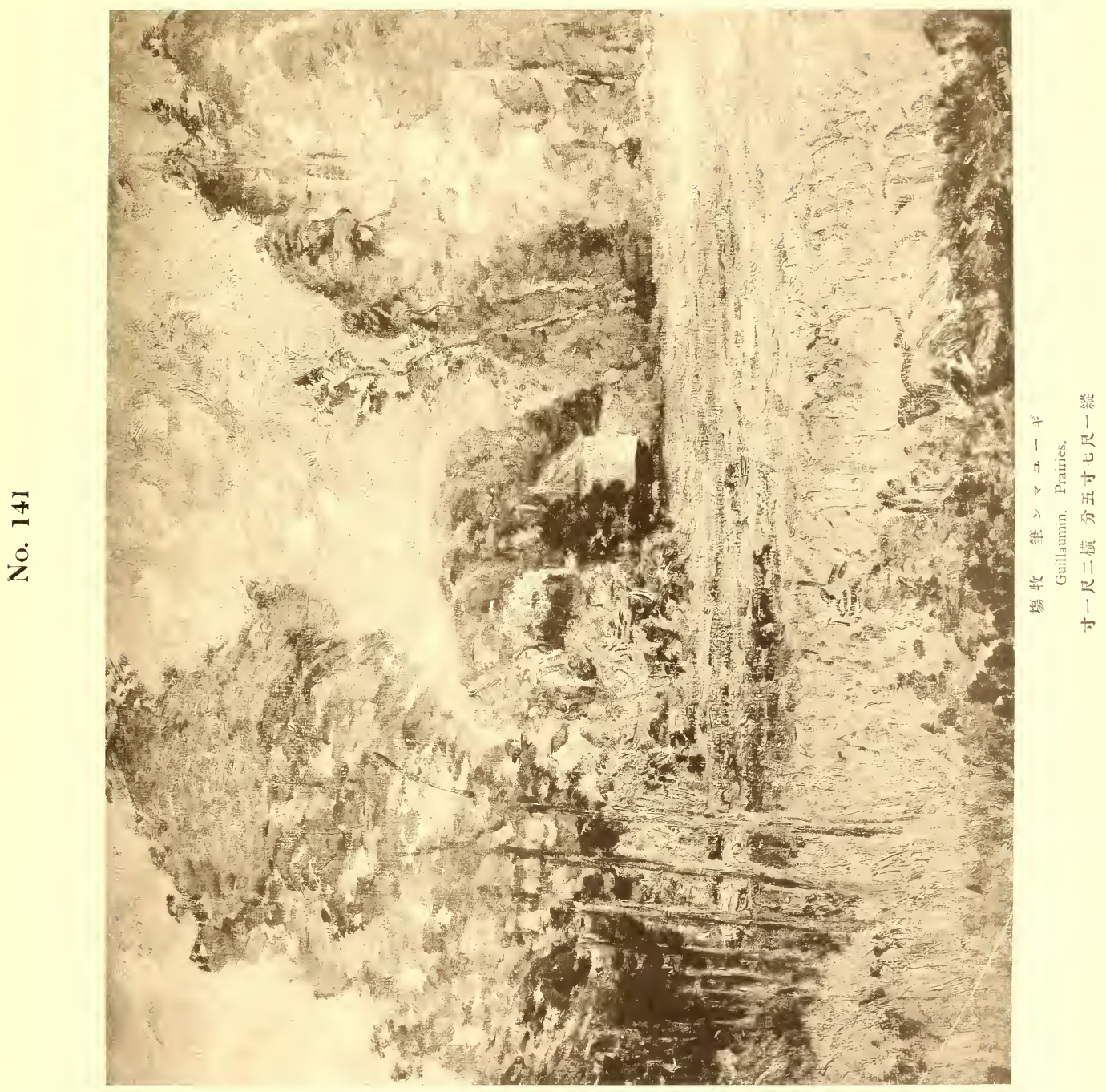


No. 141

\section{ARMAND GUILLAUMIN}

FRENCH

1841-

\section{PRAIRIES}

Height, 21 inches; length, 251\% inches

A clearing bordered by thick trees, some of which shelter buildings in the middle distance, appears in a soft but brilliant atmosphere of late sunset,-clusters of detached clouds being crimsoned by the last fiery solar rays. The green carpet of the clearing is relieved by surface growths which seem to redden in sympathy with the warm sky.

signed at the lower right, Guillaumin. 


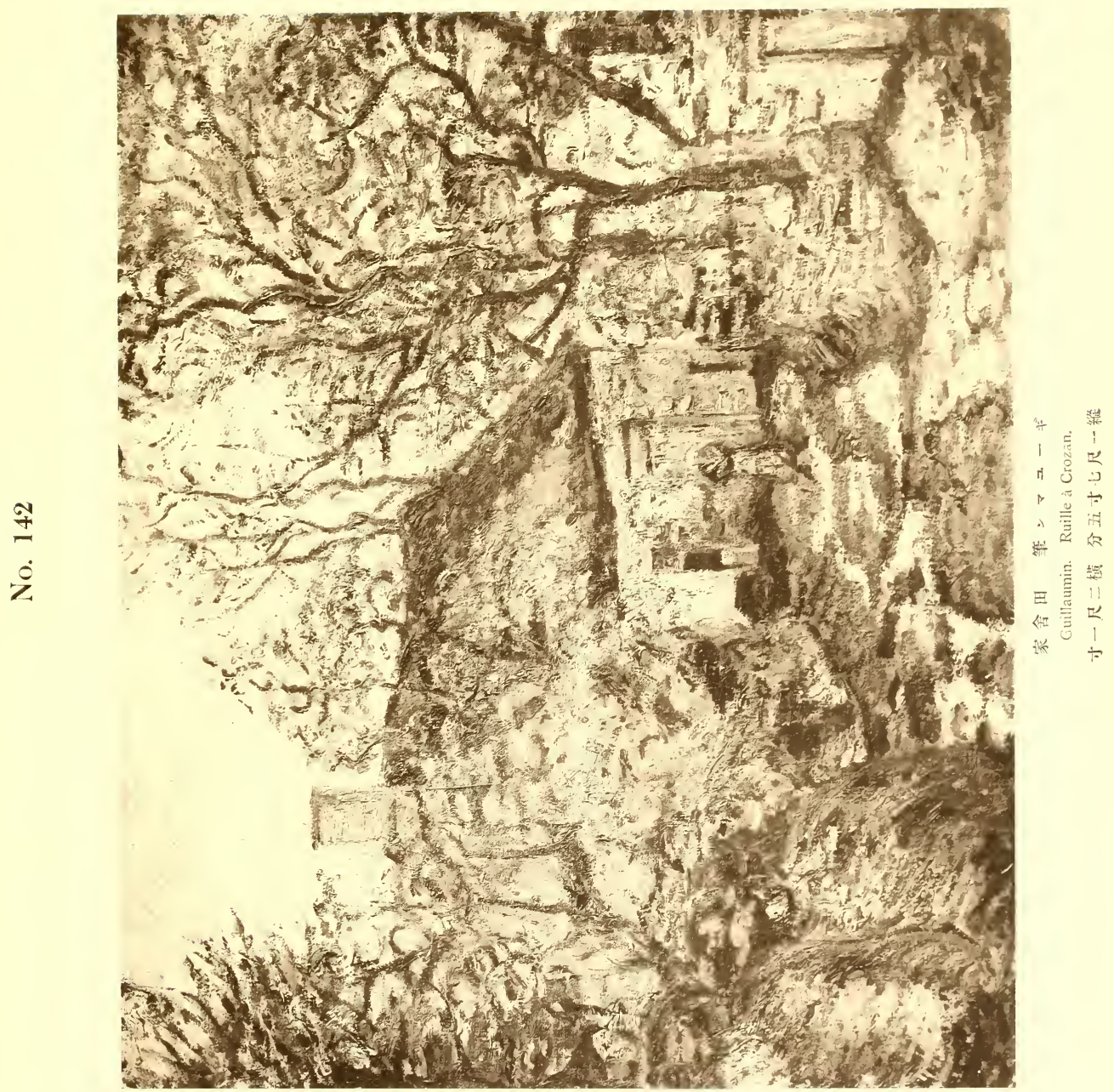


No. 142

\section{ARMAND GUILLAUMIN}

FRENCH

1841-

RUELLE I CROZAN APRES LA PLUIE

Height, 21 inches; length, 9.5.. inches

A Fresh and living impression of a picturesque grouping of peasants' cottages, trees, and an end of a narrow lane, after a shower. The leafage of the trees is sparse. Many colors are reflected from the path, boulders and buildings; and across her cottage doorway, in the middle distance, an old woman stands looking up the path.

signed at the lower right, Guillaumin. 
No. 143

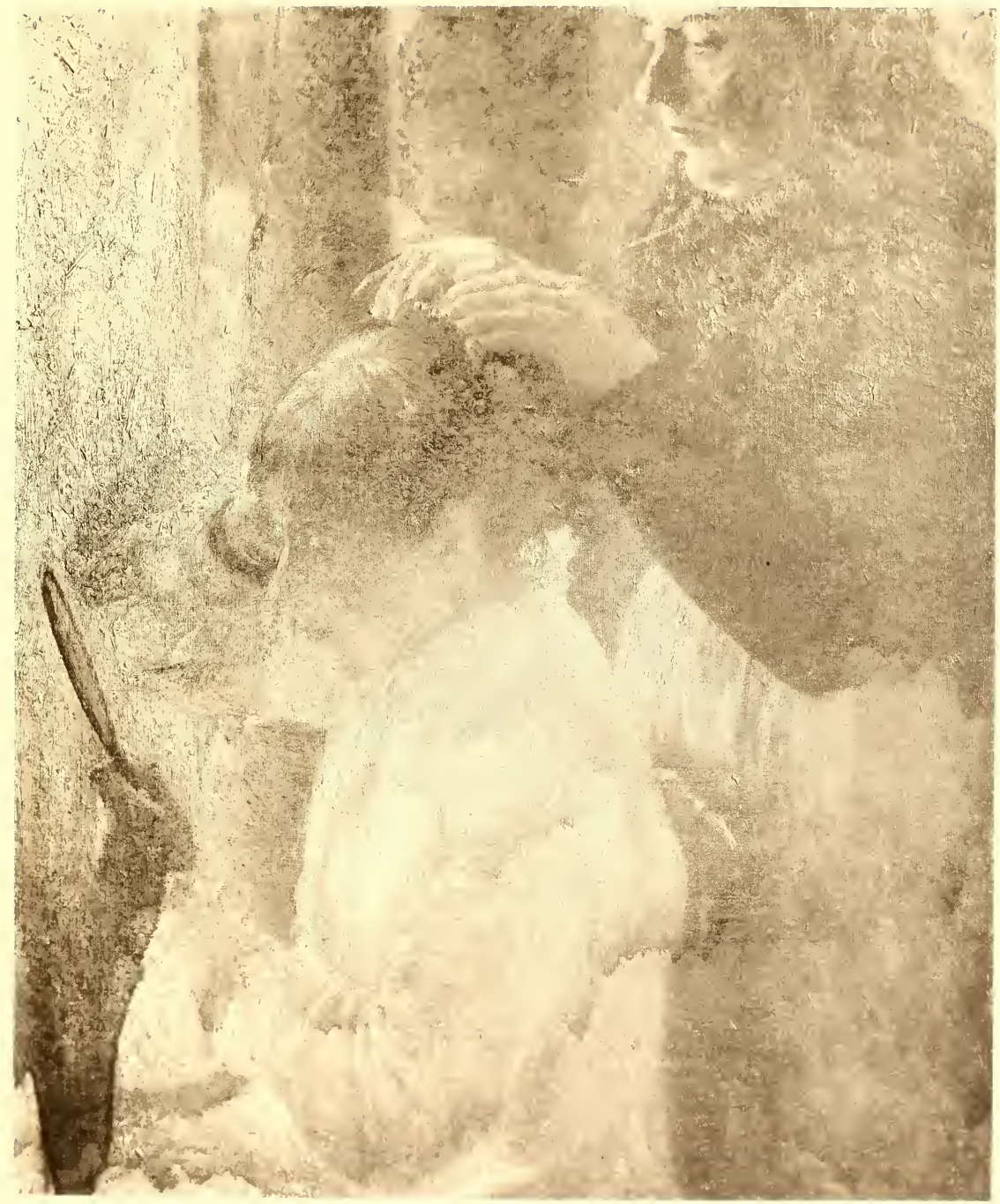

精化箻》ッホメドルバ

寸七尺一横 寸一尺二綖 
No. 143

\section{BARDOMENEGHI}

ITALIAN

\section{LA TOILE'TTE}

Height, 251/2 inches; width, 21 inches

A roung woman in a creamy-white dressing sacque is seated, facing the left, gazing into a hand mirror which she holds in her left hand, while with her right she reaches up to adjust her dark brown and banged hair. She is shown at three-quarter length, and her right wrist is encircled by a red bracelet. Back of her a woman of middle age and knotted knuckles stands helping her, both hands pressing down the girl's back hair and arranging its comb.

Signed at the lower right, Bardomeneghi. 


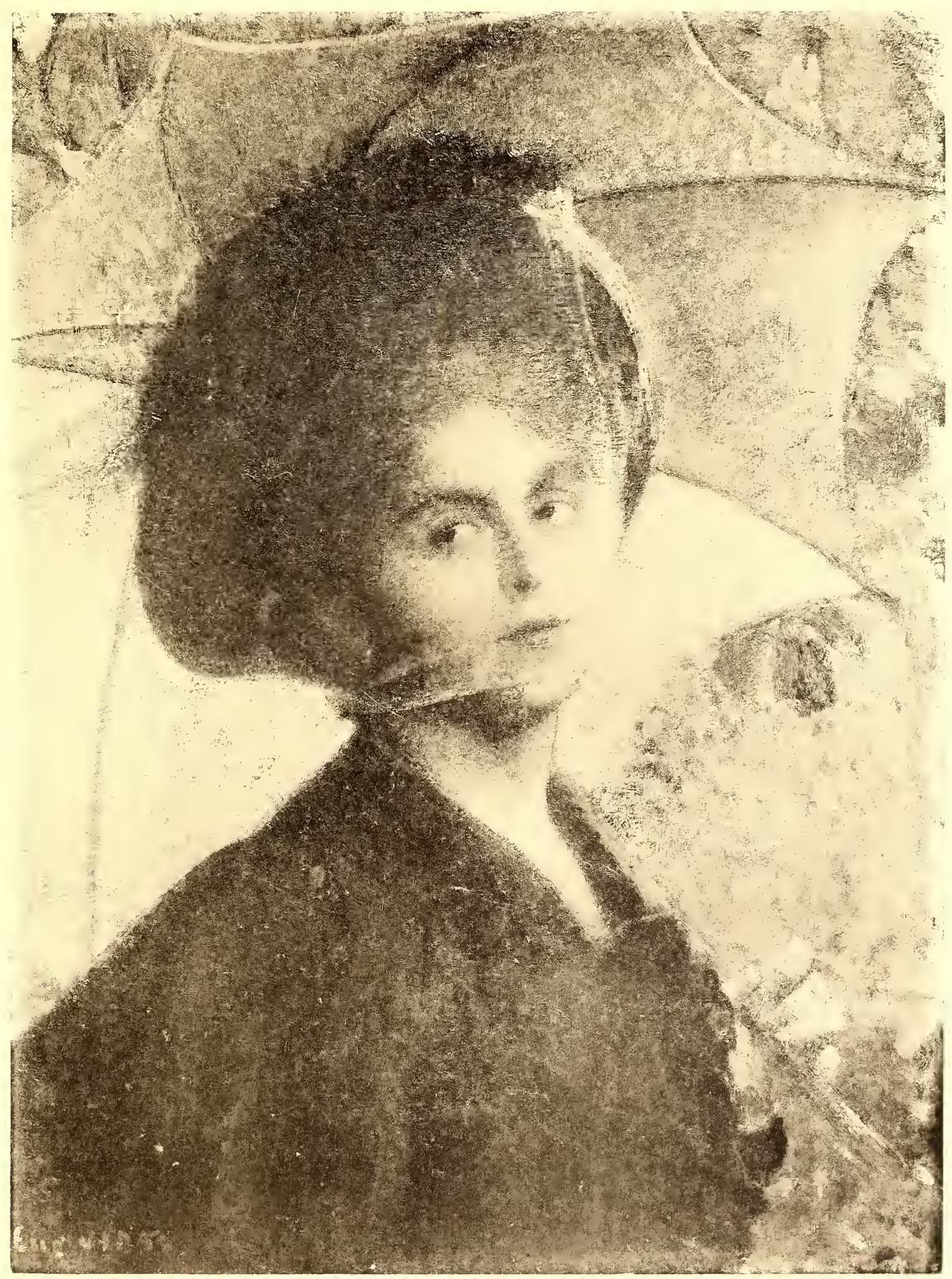

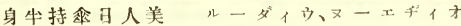

Eugène. Vidal. Dame à amhreile.

寸六尺一榉 寸二尺二維 
No. 144

\section{EUGENE VIIDL}

FRENCII

Contemporary

\section{DAME I OMBRELIE}

Height, 27 inches; width, 20 inches

A roung woman whose hair has enough red in it so that it is not likely to be overlooked, who is walking to the right, has turned to look with a mild and questioning coquettishmess over her right shoulder, so that she is seen almost full face, her wise head framed in her open, crushed rasplerry parasol, with which she screens herself from an imaginary sun. She is seen head and shoulders against a foliage background, in a black waist somewhat low in the neck, and a black hat of a former fashion,- - a fetching young woman of her time.

Signed at the lower left, Eug. Vidal. 


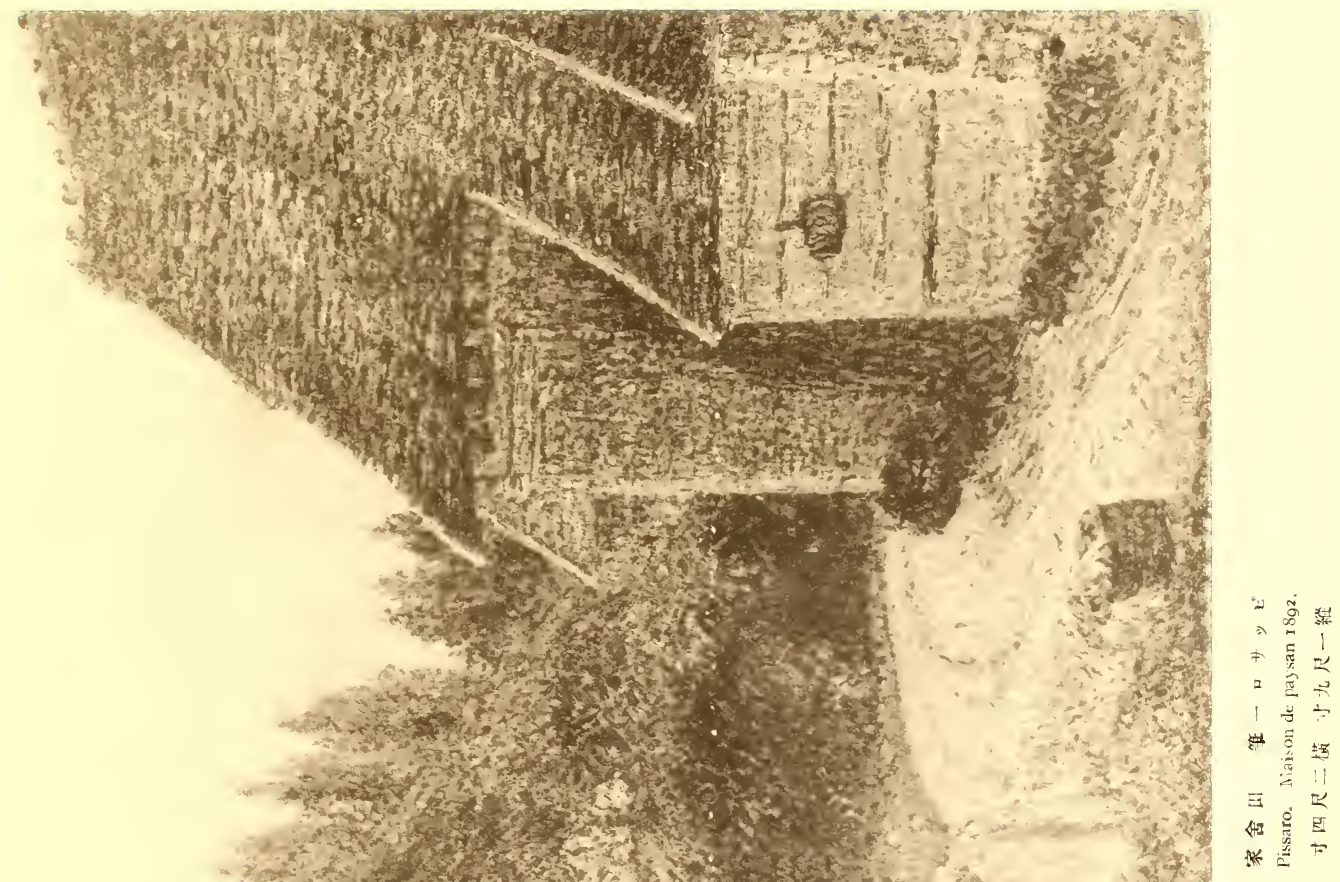


No. 14.5

\section{CAMILLE PISSARRO}

FRENCH

1810-1903

\section{MAISON DE PAYSAN}

Height, 23 inches; length, $98^{1}$ _ inches

The corner of a prosperous French farmyard is represented in the full green of summer. In the foreground a woman in a plum-colored dress and blue apron bends over a jar or can on the green lawn, and one of the domestic animals buries its head in another receptacle bohind her. Further away a child is at play on a bench, near a woman who holds an infant in her arms. Corners of the farm buildings project at the right; and beyond the garden wall, which is skirted by rows of bushes, are seen the houses and trees of the neighbors, - all in sunlight, under a blue sky with mounds of fleecy-white clouds.

Signed at the lower left, C'. Pissarro, 1892. 


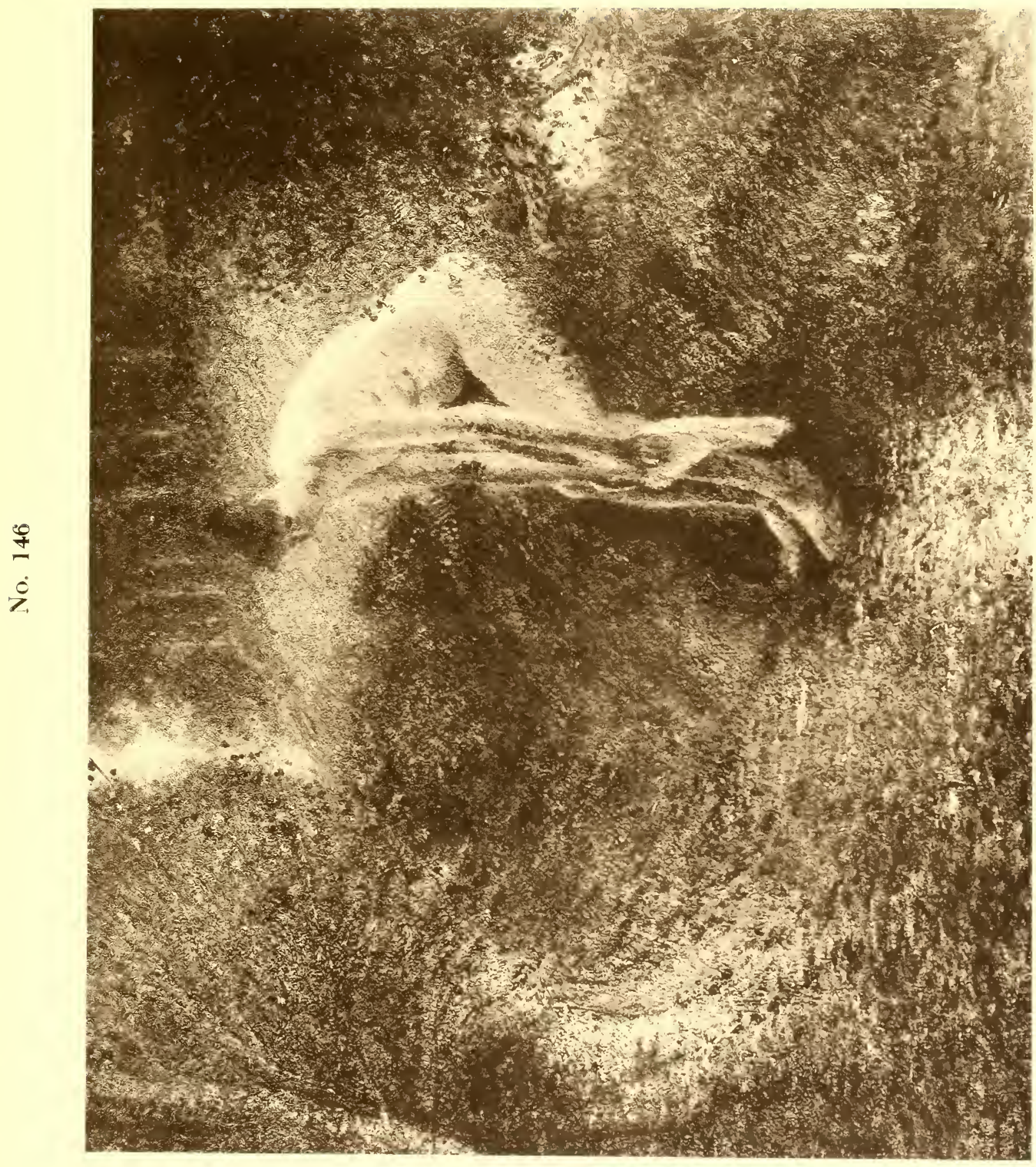


No. 146

\section{CAMILLE PISSARRO}

FRENCH

1810-1903

\section{BAIGNEUSE SEULE}

Height, 231/2 inches; length, as inches

A coor woodland stream makes its way through a glen, one of its banks showing a small clearing where the sunlight penetrates. Here, near a bush under which her clothes have been placed, a young woman of yellow hair and large figure is seated on the grass, drying herself after her bath. The water is filled with green reflections of the trees and grasses.

Signed at the lower left, C. Pissarro, 1895. 


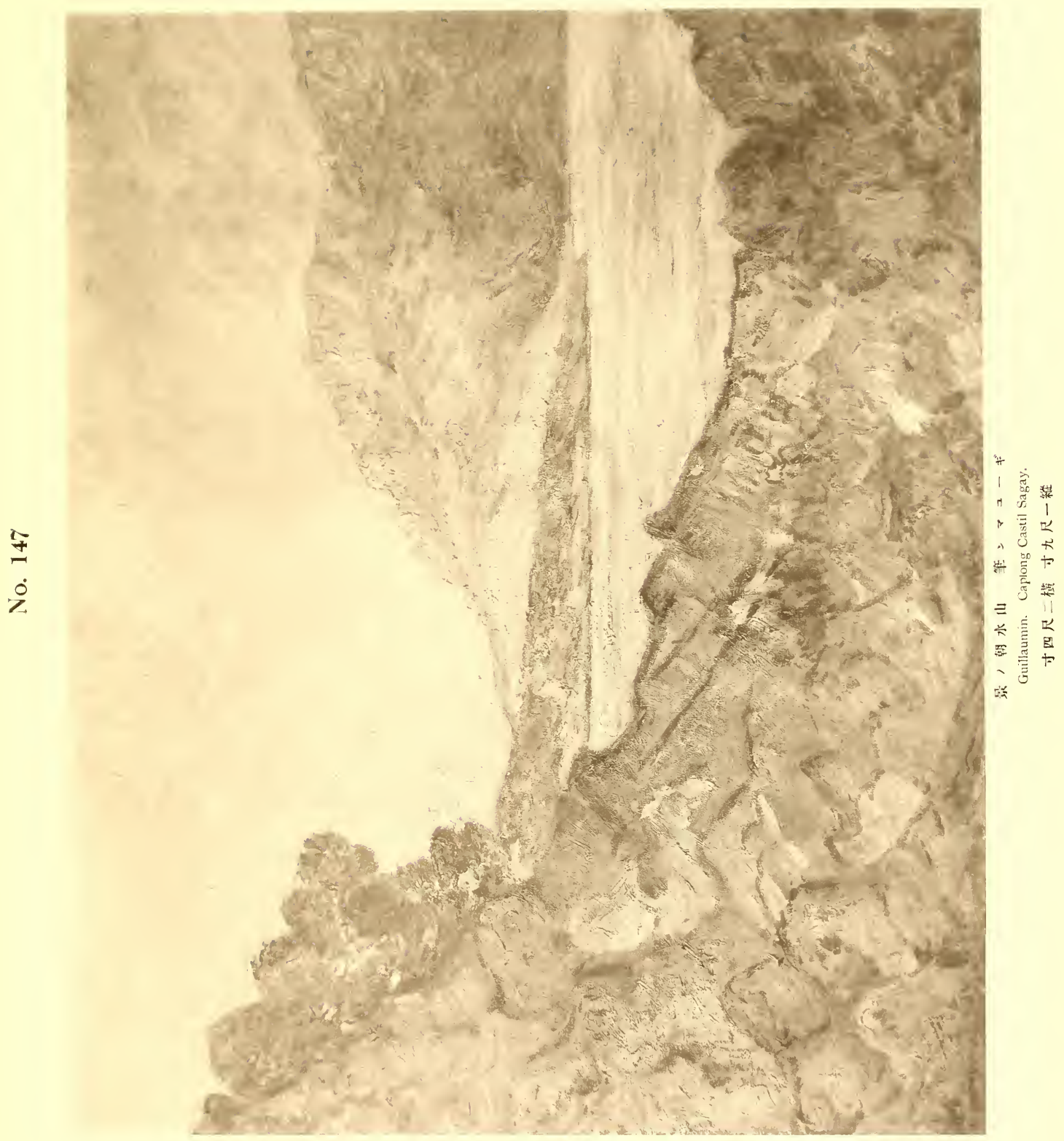


No. 147

\section{ARMAND GUILLAUMIN}

FRENCH

1841-

\section{LE CAP LONG ET LE CASTEL SAGAY}

Height, 23 inches; length, $281 / 2$ inches

RED and rugged rocks of a steep coast fill the foreground, mounting high at the left, while to the right one looks across them to a sea of intense blue in a bright, cold morning light. Beyond the arm of water a green and rolling coast climbs to more rocky cliffs, and distant hills are purple under a sky more green than blue, with suggestions of feathery clouds.

Signed at the lower left, Guillaumin.

Inscribed on the back, "Le C'ap Long ct le castel Sagay, jer "93, $9 h$ matin." 
No. 148

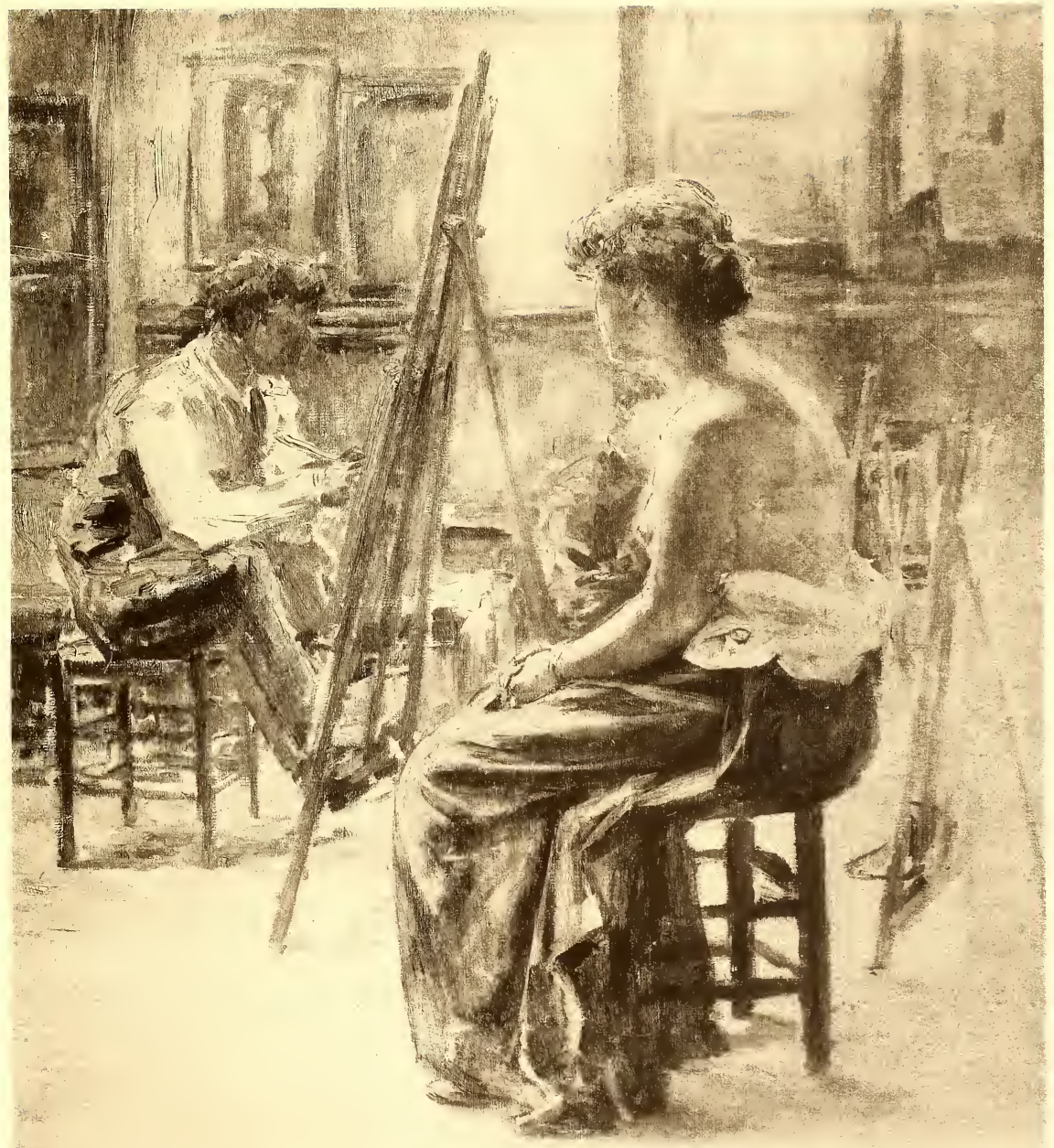

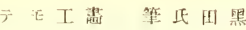

Kuroda. Le madele.
}

分五示三尺二横执尺一樅 
No. 148

\section{SEIKI KURODA}

JAPANESE

Contemporary

\section{LE MODELE}

Height, 28 inches; width, 29 inches

THE model, a blond-haired woman of sober aspect, is seated on a stool in an atelier, her black frock dropped to below her bust. She is so posed that the spectator sees her from one side, as she is turned to face two students who are painting her from different positions. A peculiar, diffused light permeates and overspreads the studio, giving to the homely fixings and properties a "quality" especially interesting to the student and amateur of painting. 
No. 149

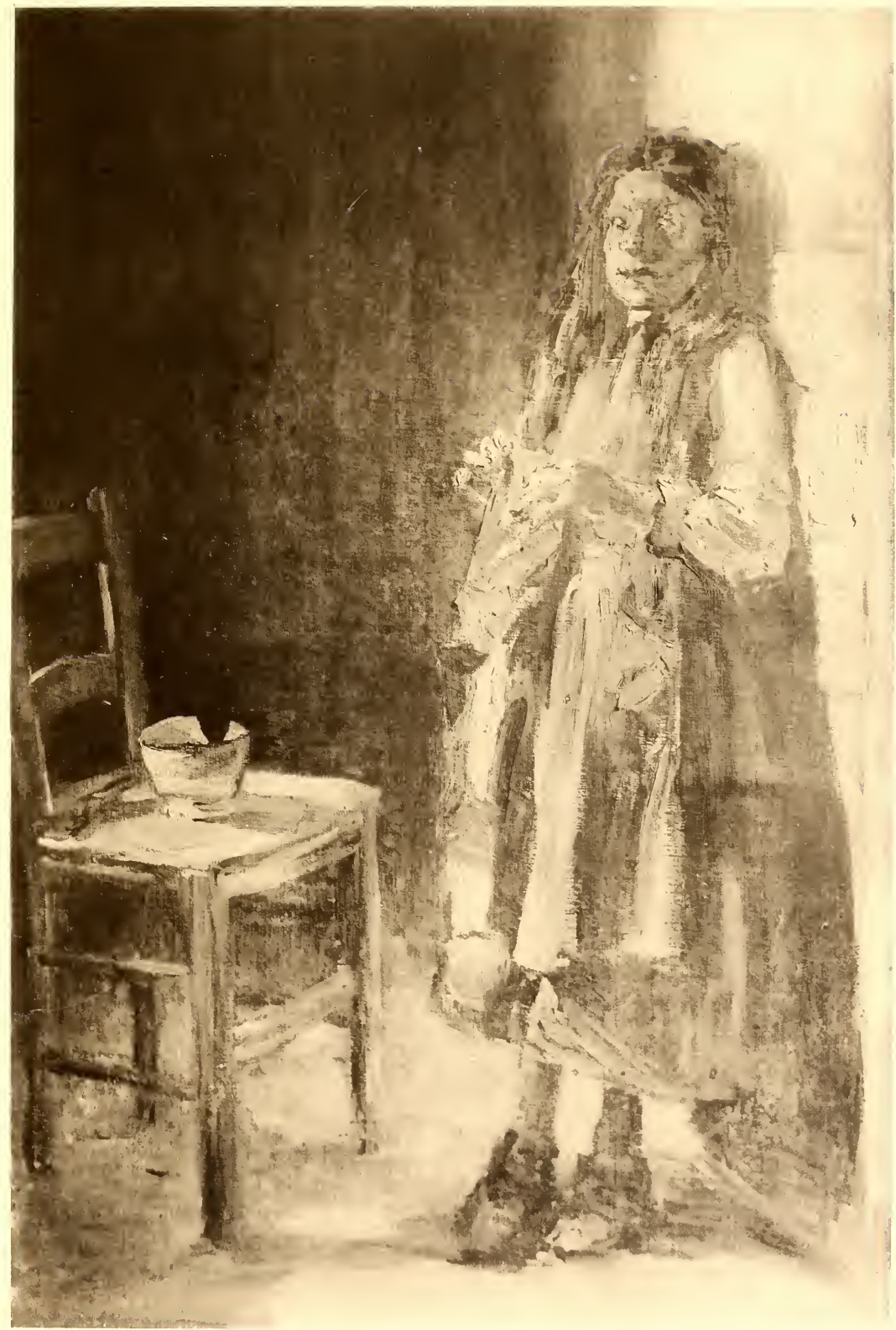

女處, 臨赤氏田哭

Kuroda. Fille aux cheveux rouges.

分五寸七尺一横对六尺二税 
No. 149

\section{SEIKI KURODA \\ JAPANESE}

Contemporary

FILLE AUX CHEVECX ROUGES

Height, 311/2 inches; width, 21 inches

Oxe of the "little women," as P'aris knows them, aged before her time-a girl with a woman's face (and here her hands), as though deformed. She stands, her yellow-red hair hanging down as if in mockery of conditions and surroundings, with her back against the bare wall of a poorly furnished room, before a chair on which a spoon and a broken bowl have been deposited. She is fingering some material, as though making preparations to sew, while her heavy face, with a story of the ages, is turned three-quarters toward the spectator. Her short dress is a greenishyellow. 


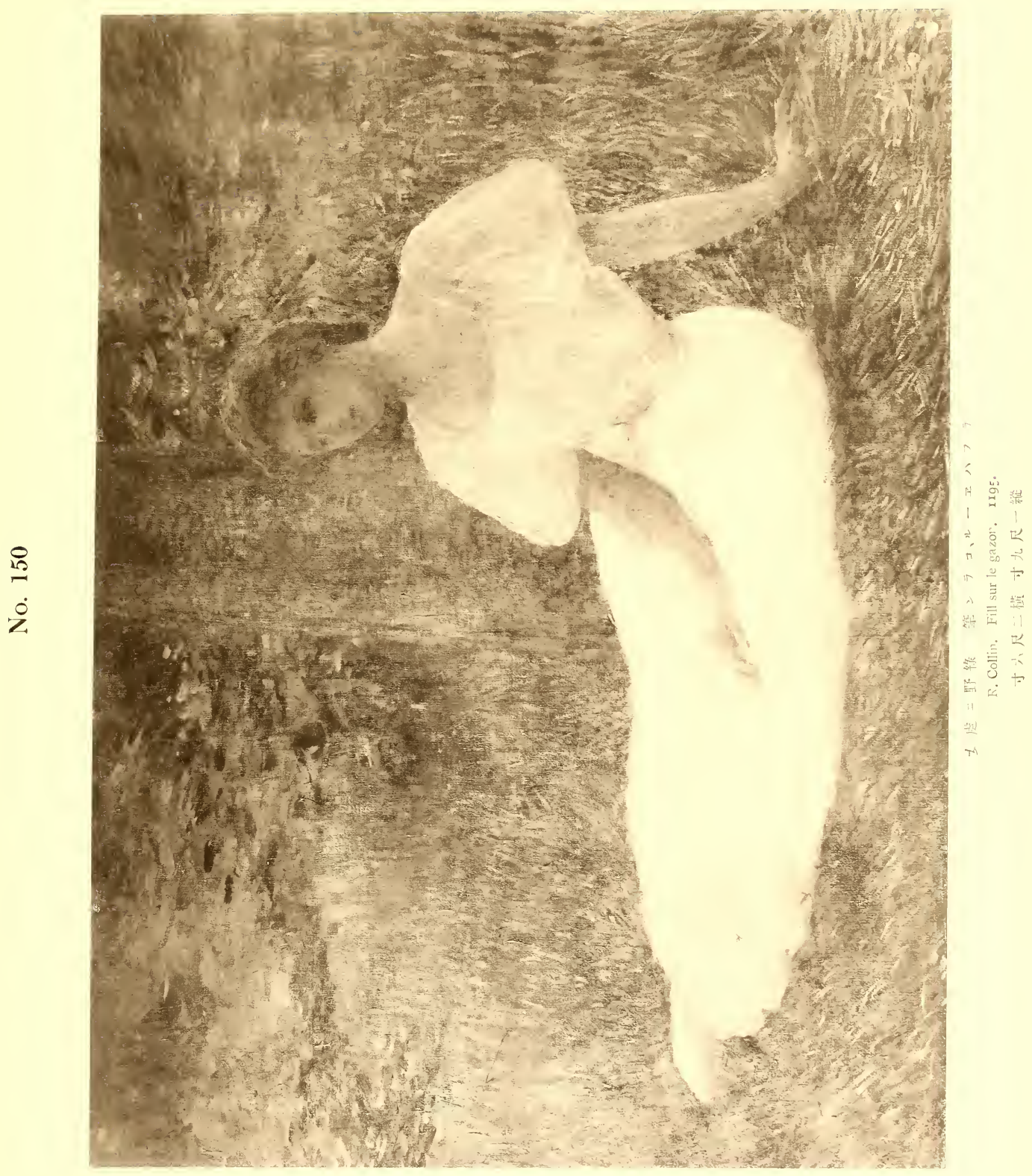


No. 1.50

\section{LOUIS JOSEPH RAPHAEL COLLIN \\ FRENCH \\ $1850-$}

FILLE SUR LE GAZON

Height, 23 inches; length, $31^{1}$-2 inches

A Benutrave young girl, her glowing hair warmed to a reddish tinge as it frames her high, well-modeled forehead, is pictured at full length, seated on the tender green grass at the foot of an isolated tree, whose trunk only is visible for a little way above her head. She is clad in white, with low neck and short sleeves, and is hatless on a warm summer day. One arm rests in her lap and she leans lightly on the other, the hand posed on the ground a little way from her. One white slipper projects from the folds of her skirt. The background is the grass and green bushes.

Signed at the lower right, R. Collin, '95. 


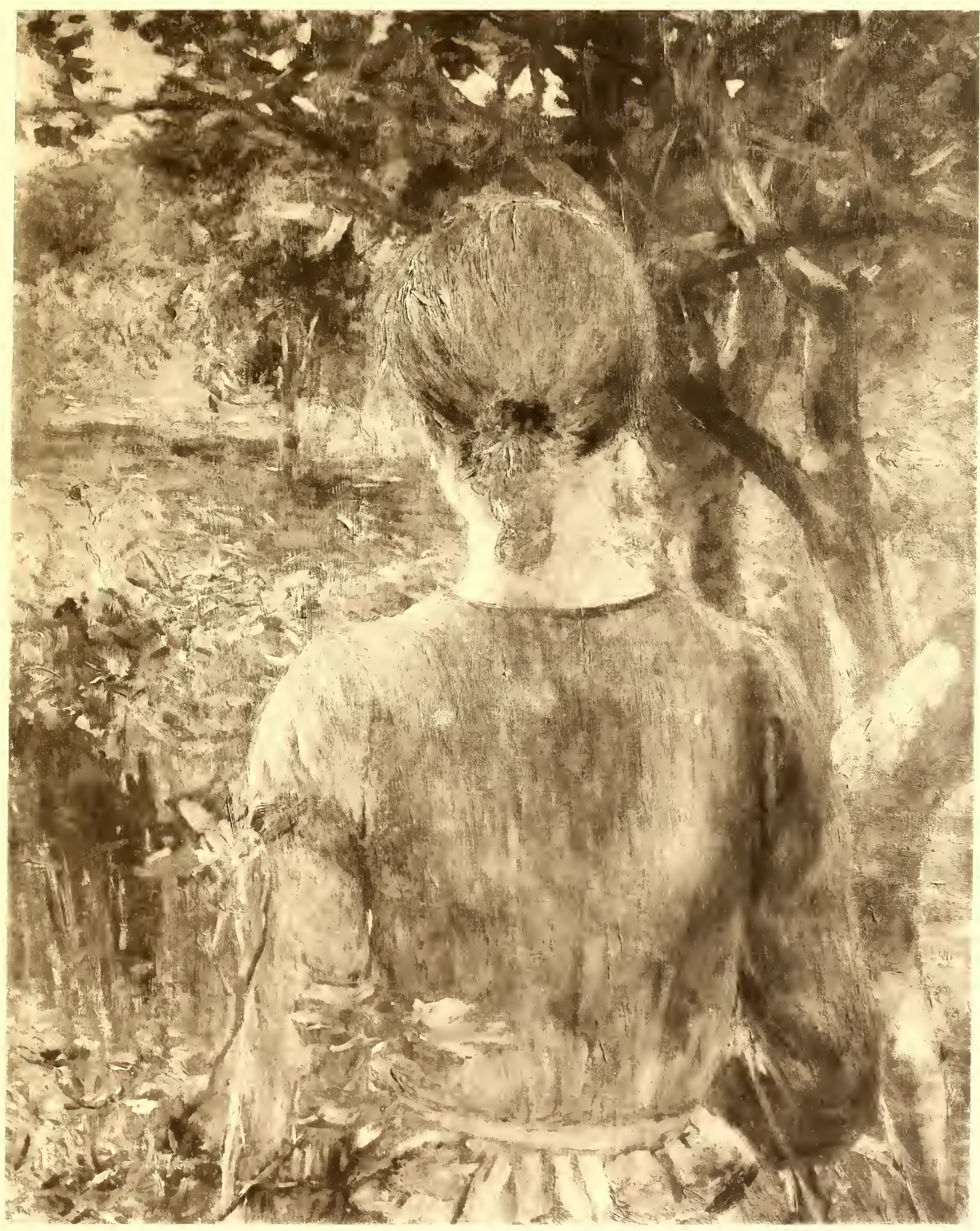

资後女處氐田照

Kuroda. fille.

寸一尺二横 寸六尺二綎 
No. 151

\section{SEIKI KURODA}

JAPANESE

Contemporary

JEUNE FILLE

Height, 31:3/1 inches; width, 251/2 inches

A roung girl, apparently of the peasant type, with pumpkin-colored laair, stands with her back toward the spectator, in a light wood. She is seen at half-length, and is clad in black, with a green band about her waist, and with the light falling from the left full upon her strange hair. At her side grow blossoming marsh plants, about a pool. 


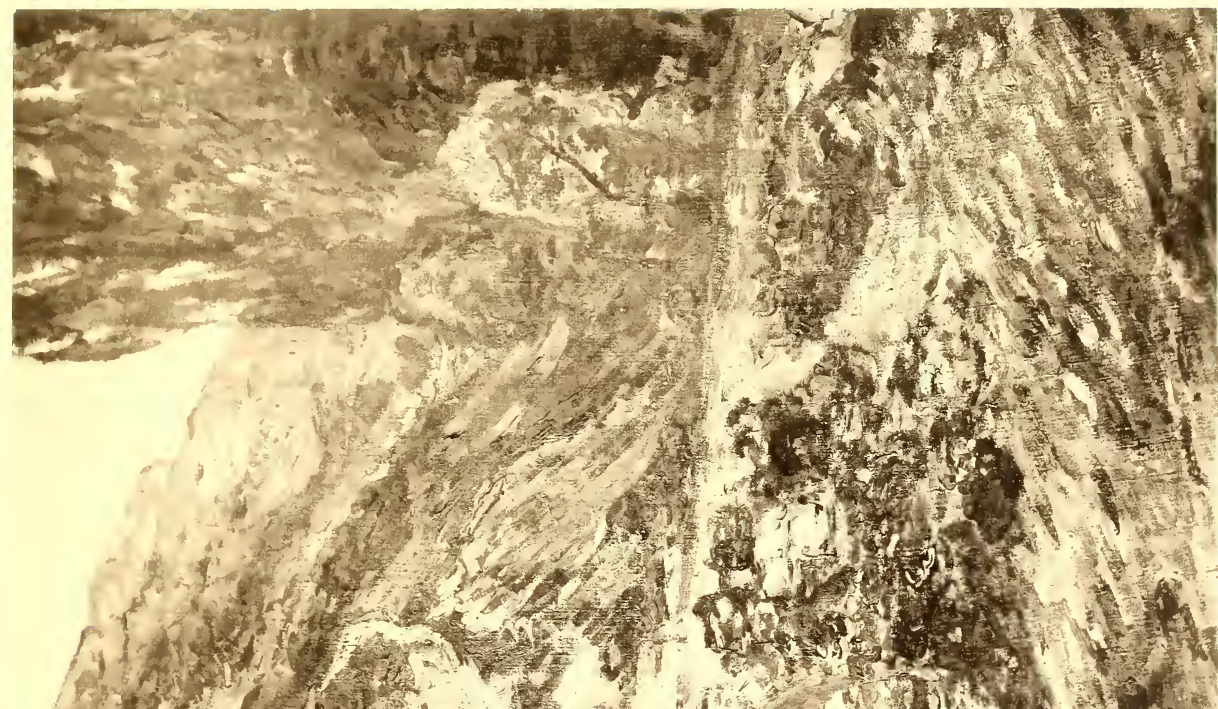

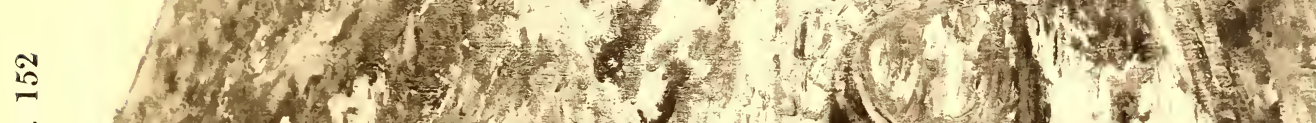

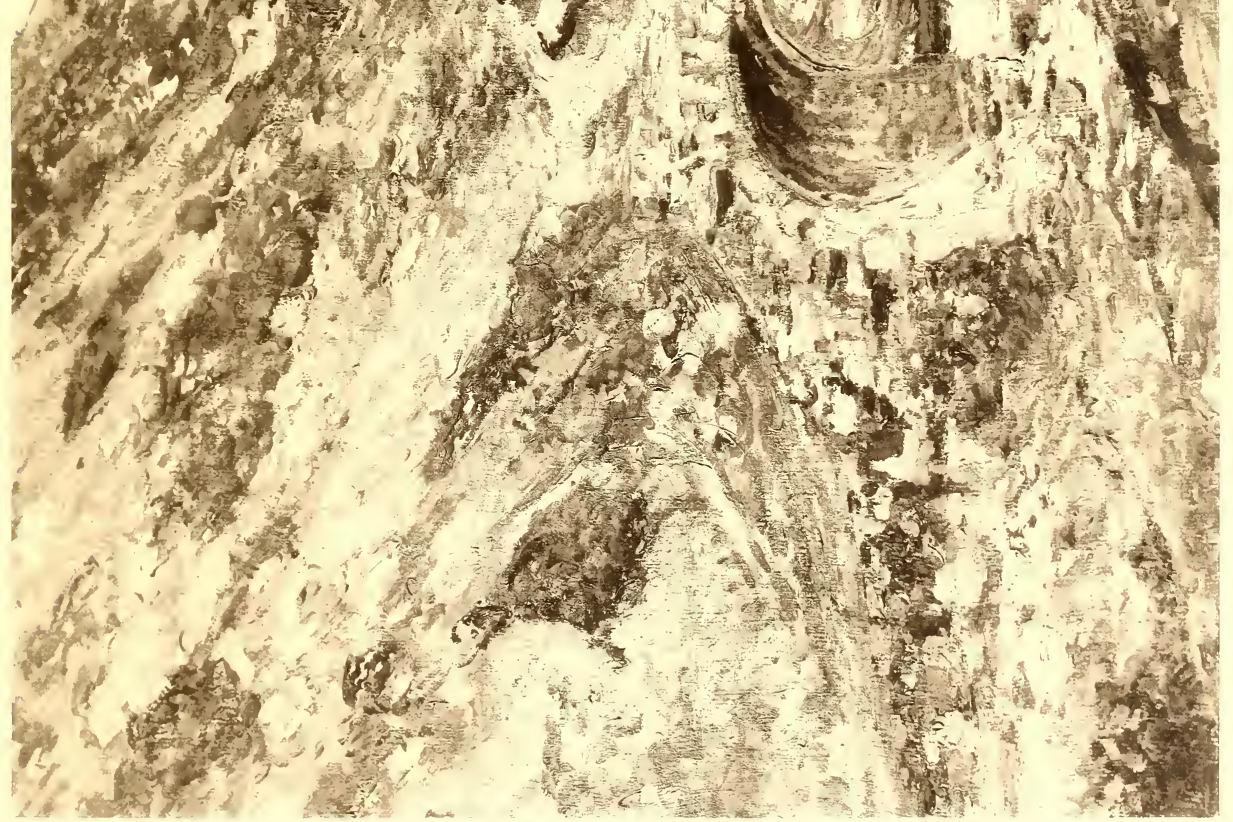


No. 152

\section{ARMAND GUILLAUMIN}

FRENCH

1841-

\section{PONT DANS LES MONTAGNES}

Height, 2.51\%2 inches; length, 313/4 inches

Ax arched stone bridge carrying a steep trail over a blue mountain rivulet occupies the center of the composition,- - picturesque in the rugged outline of its abutments and the colors of the weathered stones. To the right a group of tall trees shoot skyward, and ahead is the scarred and colorful side of the mountain range, the irregular trail climbing up and up, and losing itself in a cleft of the huge flank.

Signed at the lower right, Guillaumin. 


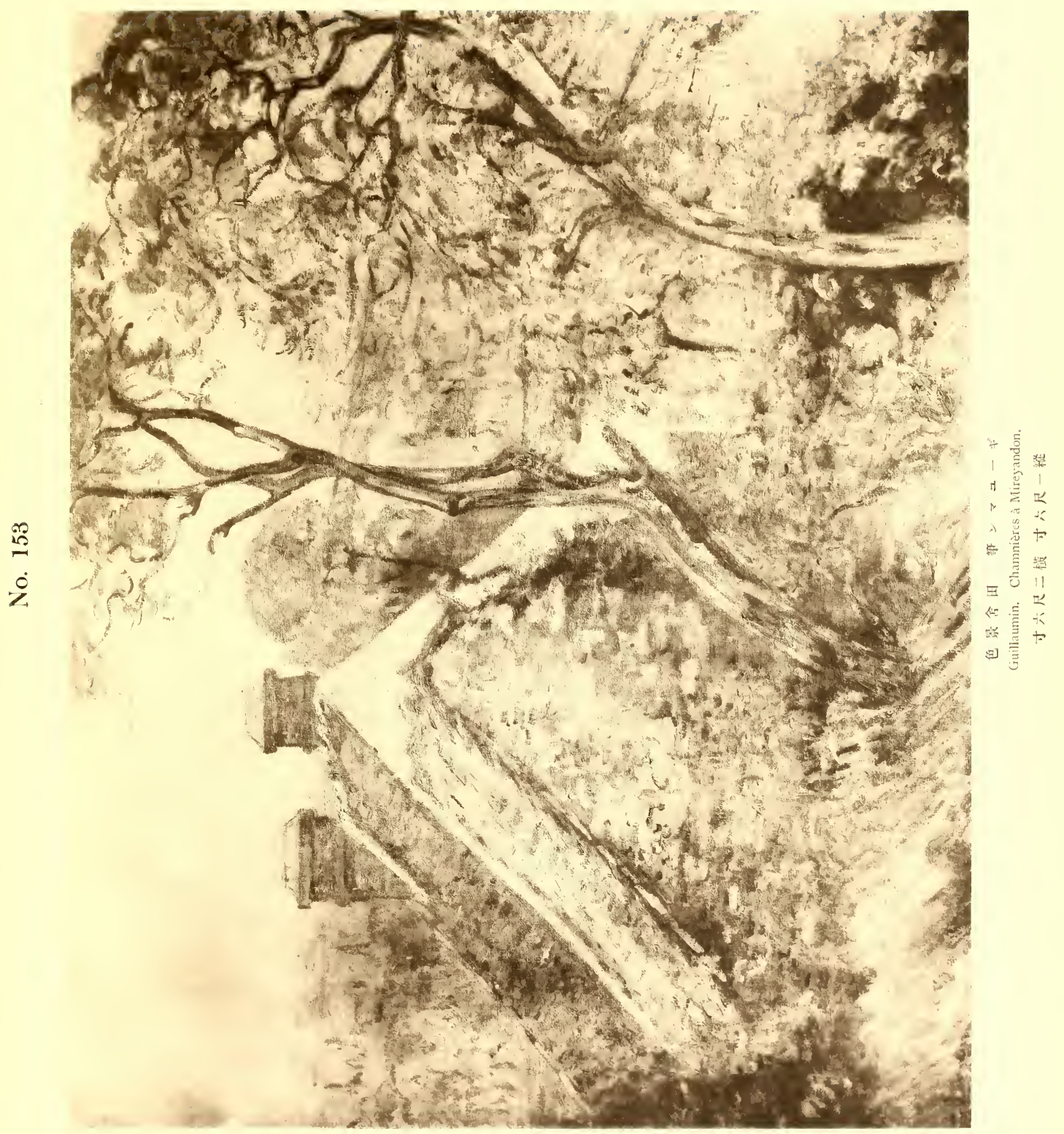


No. 153

\section{ARMAND GUILLAUMIN \\ FRENCH}

$1841-$

\section{CIIAUMIERES A MIREYANDON}

Height, 251/. inches; length, 311\% inches

IT is a June morning with light gray clouds prevailing after a time of rain or mist, but with no haze left over a varied landscape. Brick-chimneyed cottages rise in reddish, purple and mottled aspect near two curved and leaning trees of the foreground, beyond and about them being more trees, and bushes and grass in profusion. In the distance is a field under cultivation, bordered beyond by a line of trees which appear deep blue at the horizon.

Signed at the lower left, Guillaumin.

On the back is written the title, and the memorandum ("le matin, temps gris,-? Juin, de $7 \mathrm{hr}$. ?") 


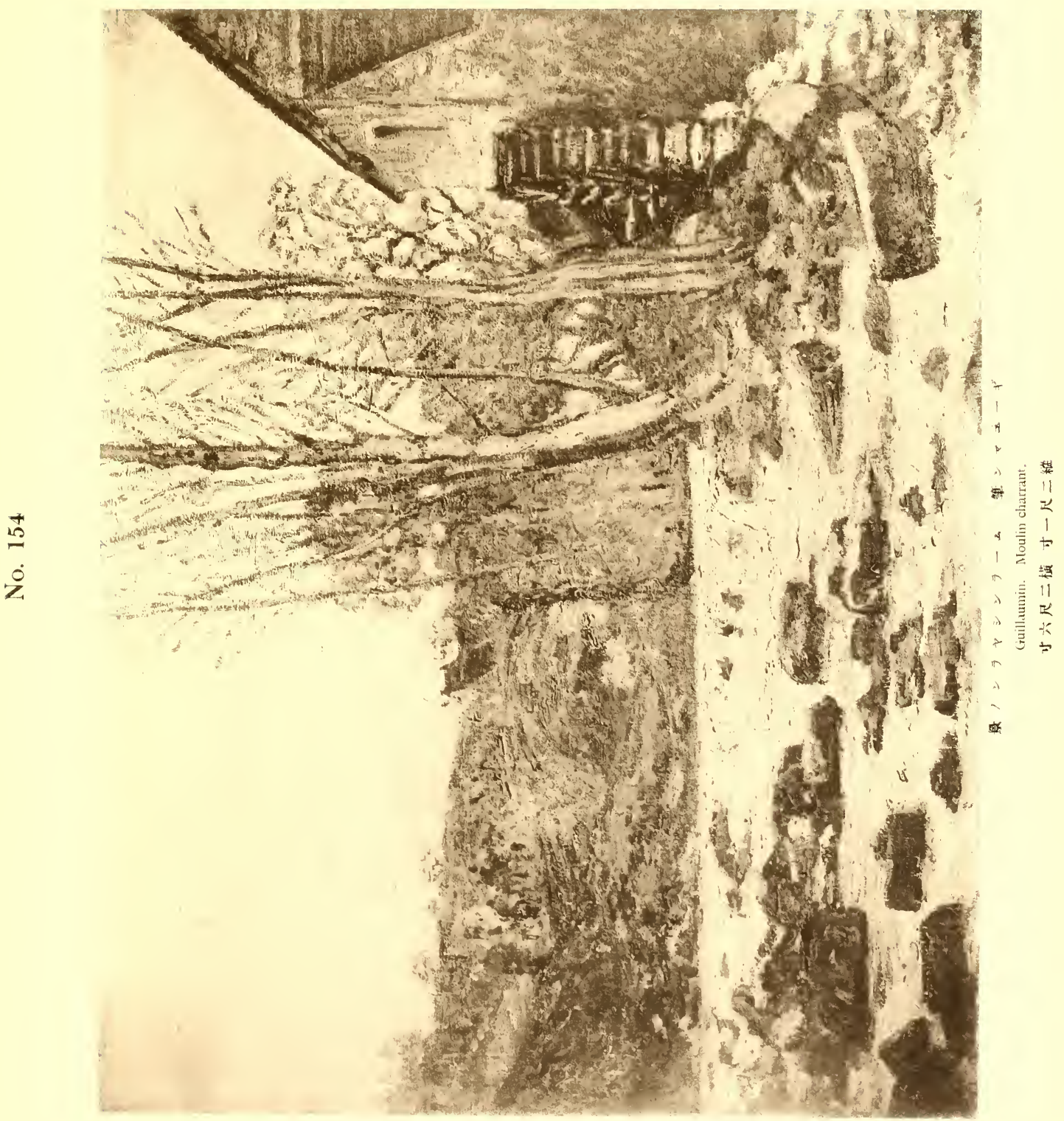


No, 1.54

\section{ARMAND GUILLAUMIN \\ FRENCH}

$1841-$

MOULIN A CHARENTON

Height, 251/2 inches; length, 31\%/4 inches

In the midst of a refreshing landscape in an undulating country, an old mill stands in the course of a stream whose current runs swiftly among rocks and small boulders. The big water-wheel is seen at the end of the building, in the stream which fills the foreground, dotted, as has been said, with small boulders and jagged pieces of rock. The rolling hills beyond have trees and houses and color, under a bright blue sky streaked horizontally with white clouds.

Signed at the lower left, Guillaumin. 


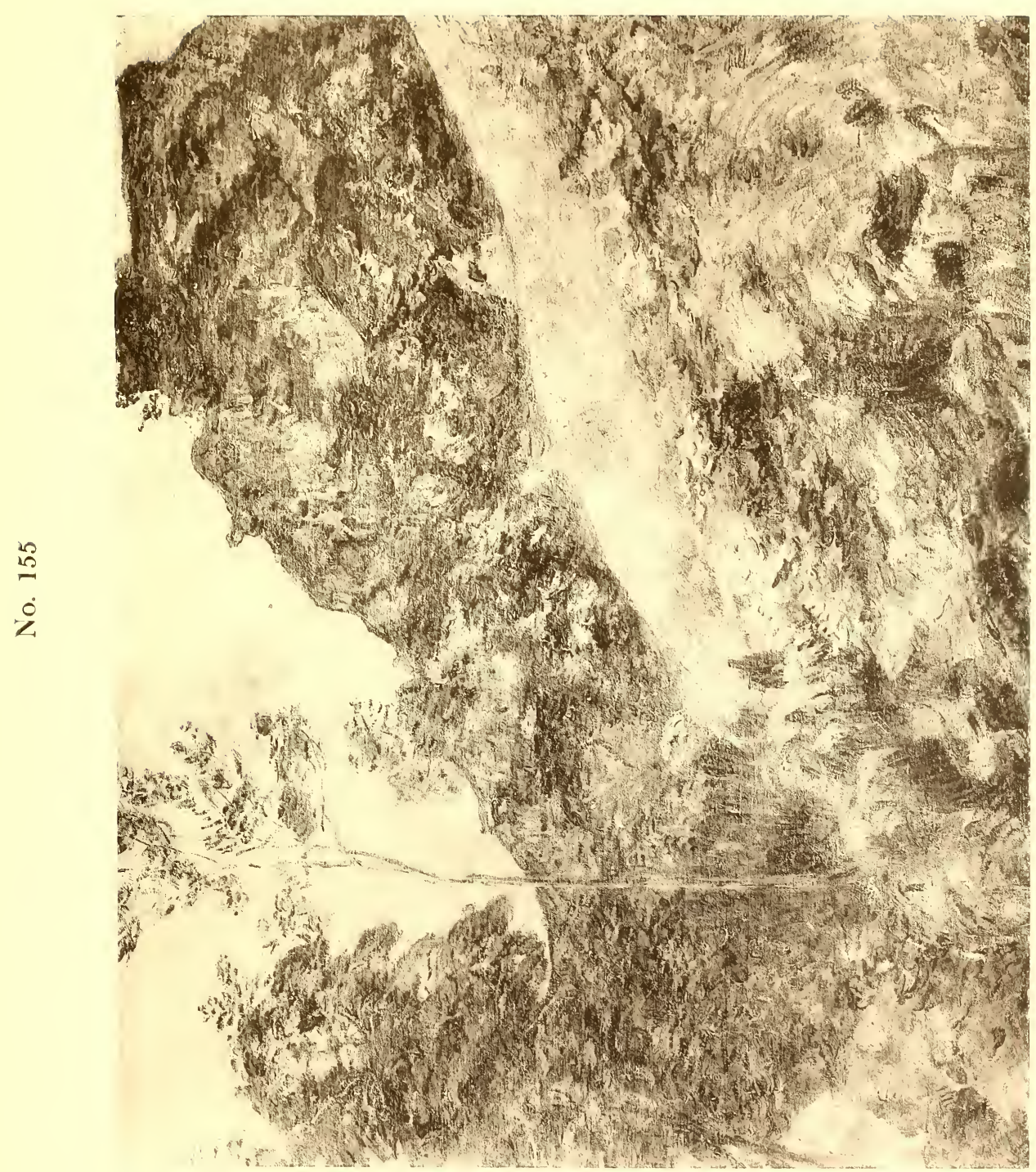


No. 155

\section{ARMIND GUILLAUMIN}

FRENCH

1841-

\section{VALLEE}

Height, 251/2 inehes; length, 311/2 inches

THE spectator looks across the rounded slope of a hill at the right, where sunlight has coaxed flowers into bloom, past green trees whose tops only are visible on the hill's farther side, to a bold, jagged hill beyond, which looms high under a strong sky. A landscape of green and purple, of trees, rocks and flowers, of hills and chasms and indicated valleys, and of sunshine.

Signed at the lower left, Guilloumin. 


\section{No. 156}

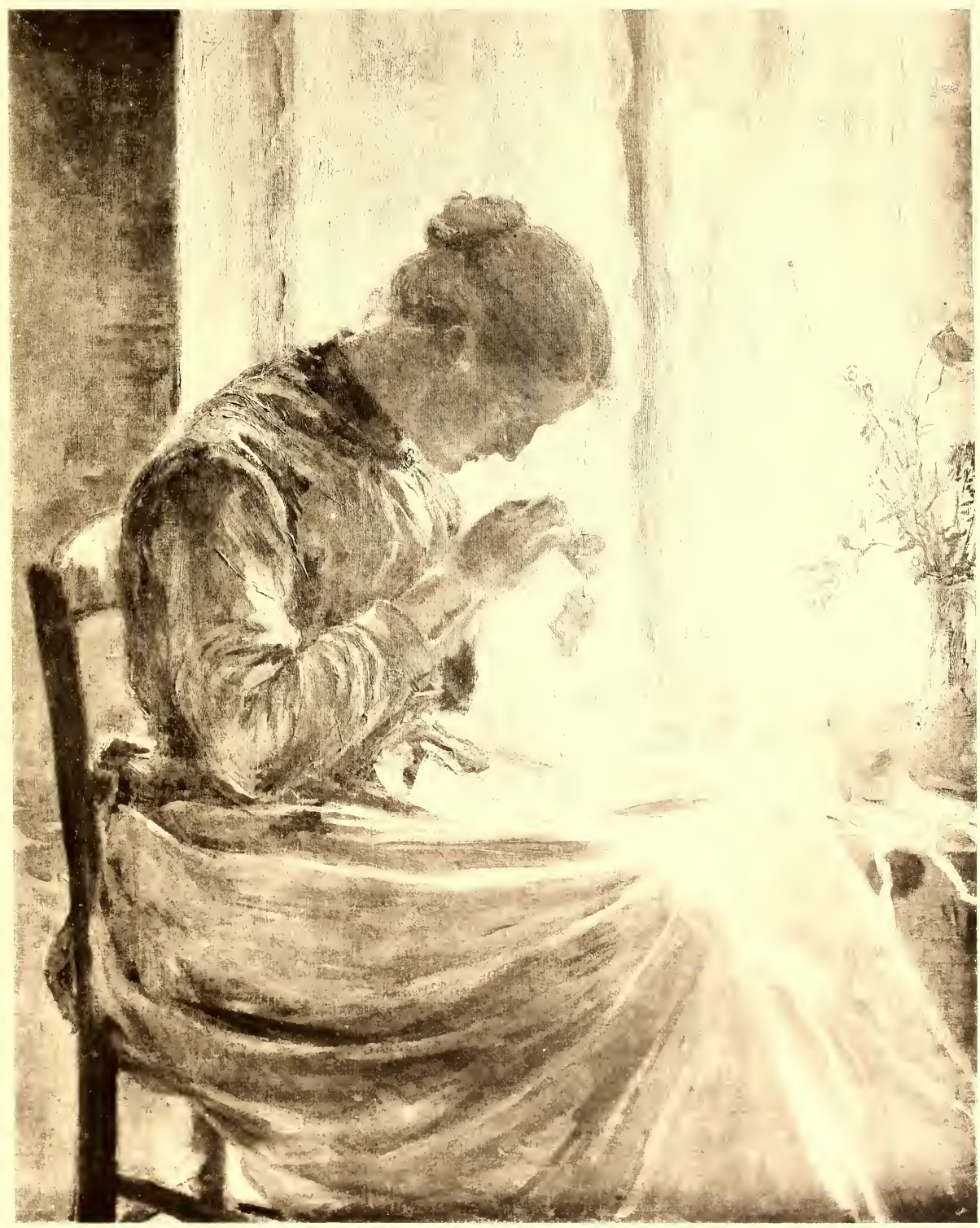

事任針氏四哭

Kuroda, Couturiere.

寸一尺二梚小六尺二絽 
No. 156

\section{SEIKI KURODA}

\section{JAPANESE}

Contemporary

\section{COUTURIËRE}

Hcight, 313/4 inches; width, 251/2 inches

A woman of young-middle age is seated at her windowa small bouquet of simple flowers in a pitcher on the sillworking at her sewing. She faces the right, and her face is seen in profile against the white curtain, as, clad in black, she bends over her dressmaking task. 


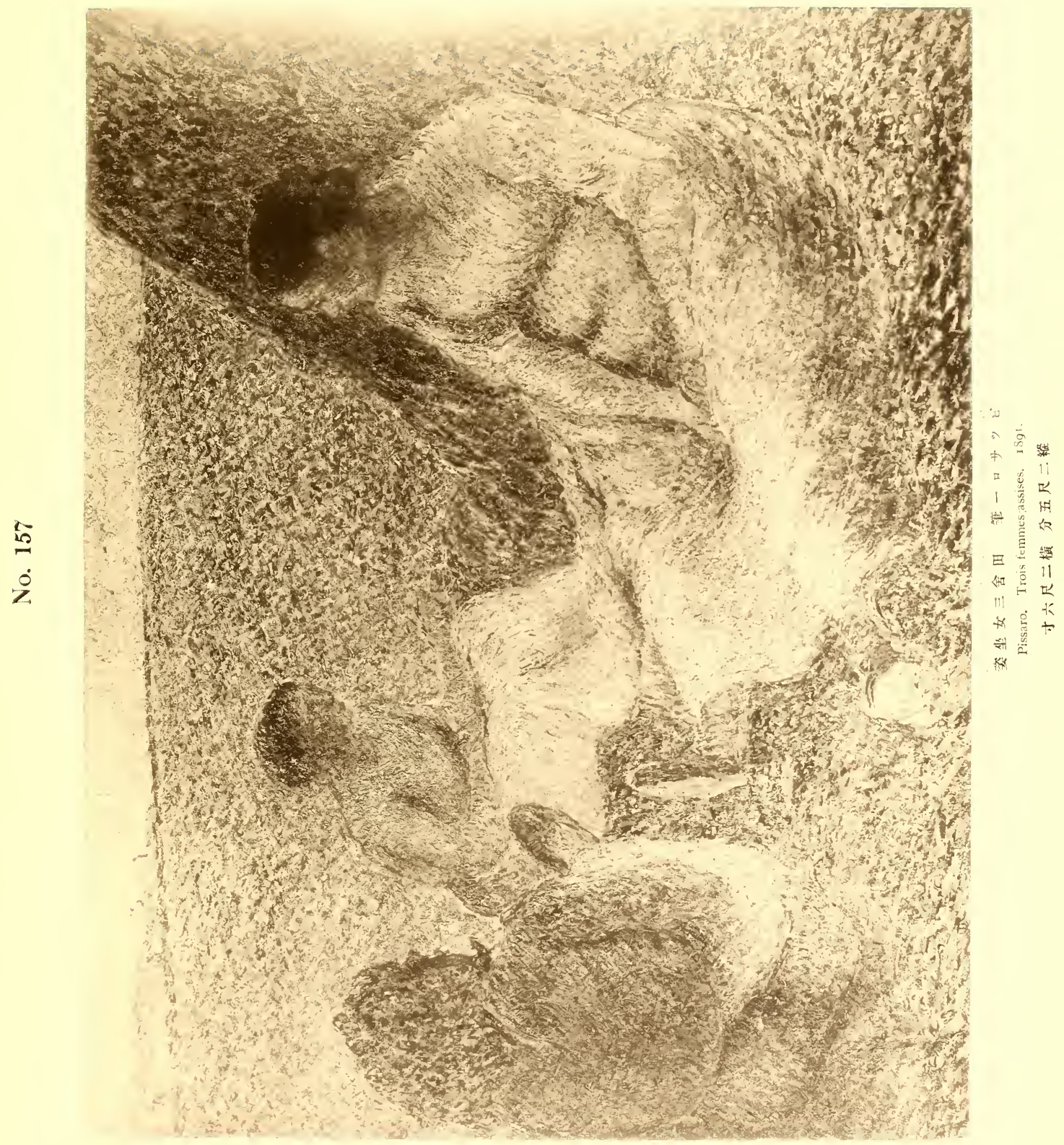


No. 157

\title{
CAMILLE PISSARRO
}

FRENCH

1810-1903

\section{FANEUSES AU REPOS}

\author{
Height, 251/2 inches; length, 31\%/4 inches
}

These three peasant women, laborers in the fields, have stopped to rest, and to gossip a little, in the heat of the noontide, when in the nearly perpendicular light there is scarcely a shadow. They are wearied, yet alert, and in the pause in their haying have assembled at the foot of a haystack, against the base of which one of them leans. Two are young, and all are heavy; the younger ones in blue frocks - one bare-headed, one in a red headdressthe elder woman, who is seated back to the spectator, in old red, and wearing a green head covering tied about her ears and under her chin. Beyond them are the fields, and on distant hilltops are seen more of the neatly rounded stacks.

Signed at the lower left, C. Pissarro, 1891. 


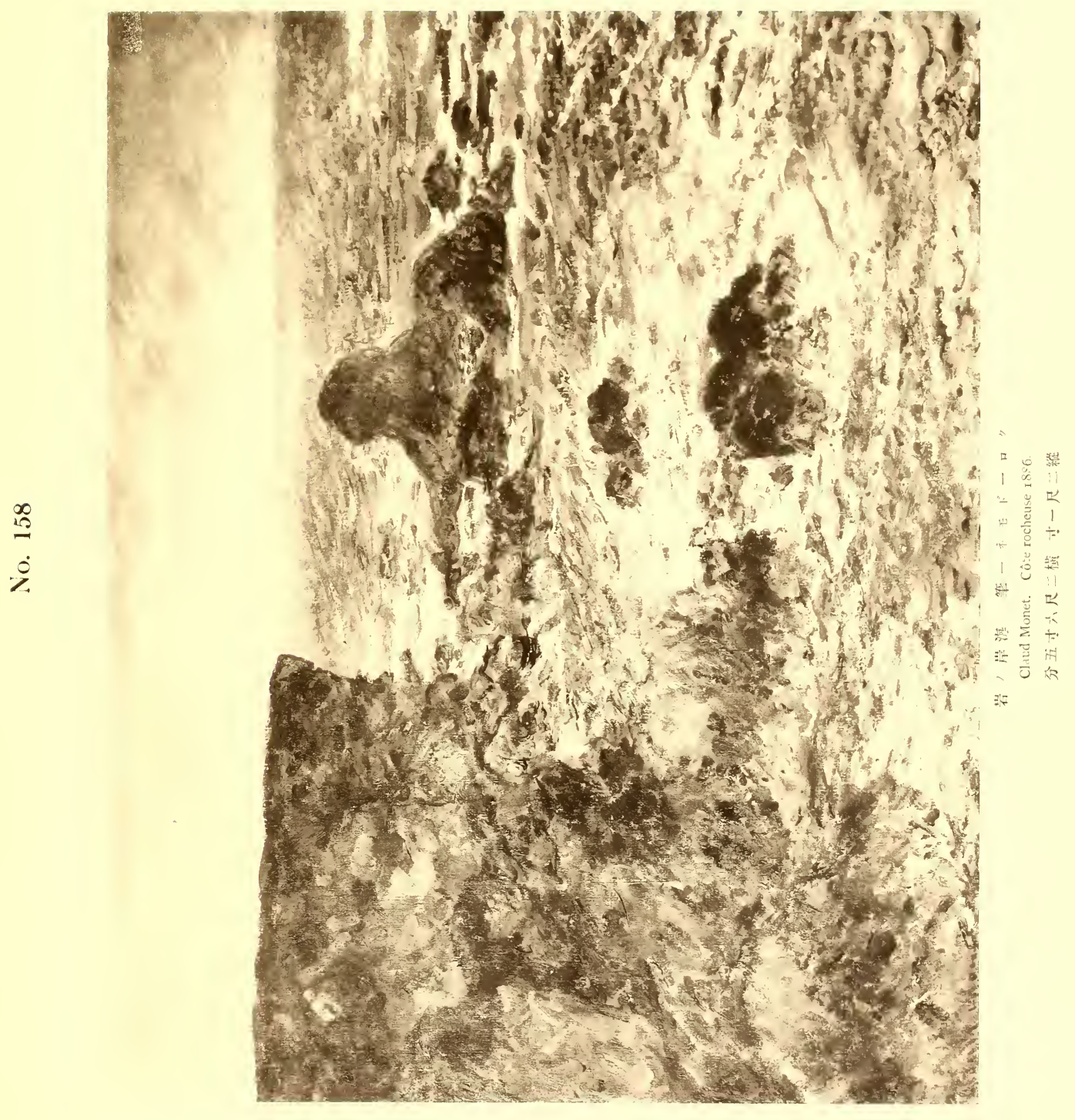


No. 1.58

\section{CLALDE MONE'T}

FRENCH

1840-

CO'TE ROCHELSE

Height, $2.5^{1 / 2}$ inches; length, 31:3/4 inches

The blue sea in the distance appears under a lively, purplish-gray sky, the nearer waters becoming a light green as they approach the outlying reefs of a rocky coast and break in foam on their extended and irregular bases. Inshore of these brown outposts of the inhospitable land, the water swirls gently and tosses up harmless froth; and then abruptly rise sheer, reddish-brown cliffs, ominous and solid, and seen by Monet in their solemnity with the artist's ere.

Signced at the lower lejt, Claude Honet, '86. 


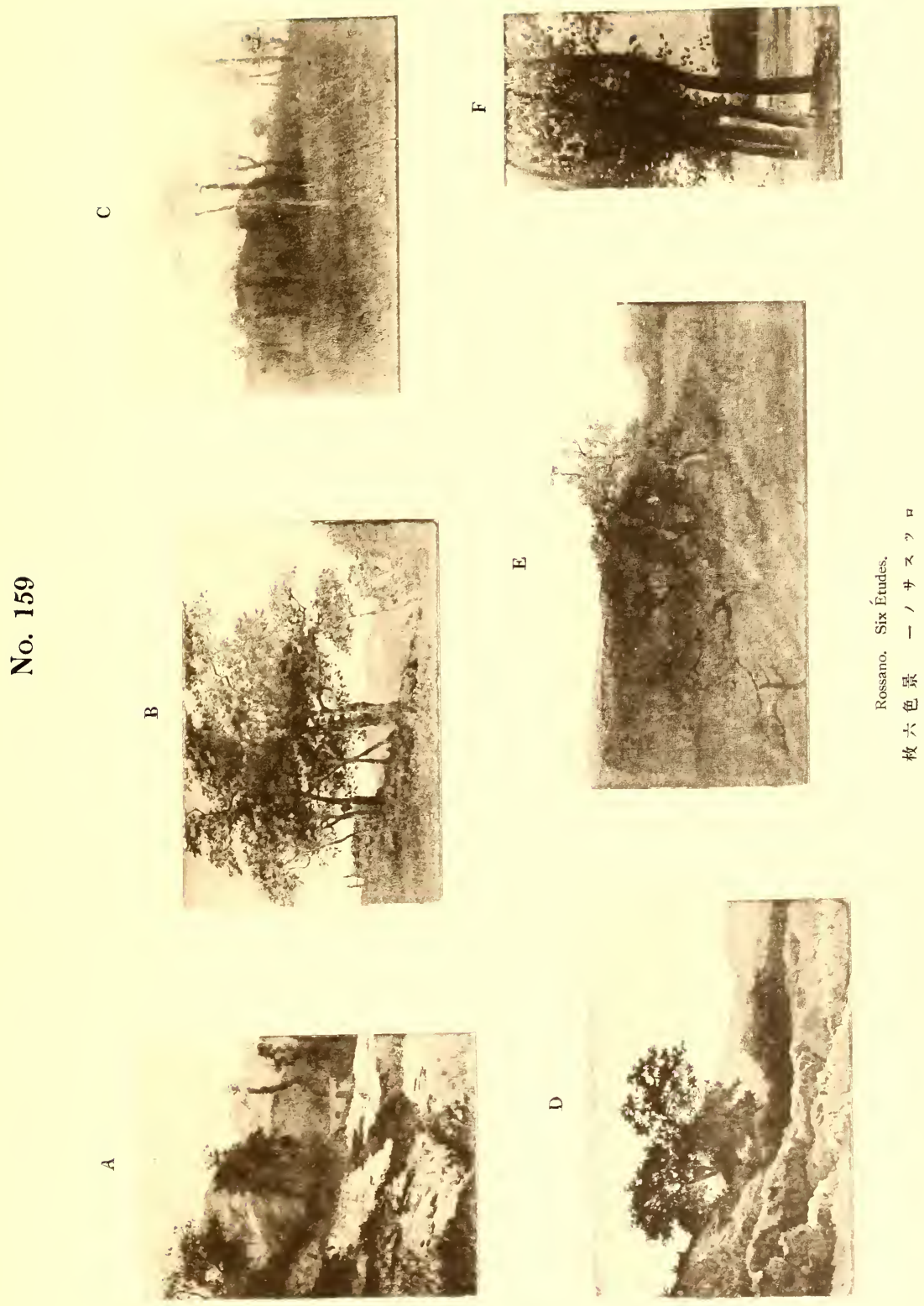


No. 159

\section{E. ROSSANO}

\section{I'TALIAN}

Contemporary

\section{SIX E'TUDES}

A-

$$
\text { Height, 141\%2 inehes; width, } 11 \text { inehes }
$$

A SEAMED and sloping hillside of gray rocks, with verdure and occasional trees springing up among them,- a large fissure or glen in the middle distance being crossed by a stone arched bridge or viaduct.

Signed at the lower right, Rossano.

B-

$$
\text { Height, 111/2 inehes; length, } 16 \text { inehes }
$$

A gRoup of trees, in the country.

Signed at the lower right, Rossano.

$\mathrm{C}-$

$$
\text { Height, 111/2 inehes; length, } 16 \text { inches }
$$

Lesfless, vine-wound trees, standing in irregular order on the broadly sloping top of a deserted hill.

Signed at the lower left, Rossano.

$\mathrm{D}$

$$
\text { Height, 101/2 inehes; length, } 16 \text { inehes }
$$

Gray and green. An active gray sky over a dull and barren landscape relieved by a low line of green trees and bushes.

Signed at the lower right, Rossano.

E-

$$
\text { Height, } 11 \text { inehes; length, } 20 \text { inehes }
$$

STuDies of irregularly growing trees on the gently sloping back of a broad hill.

Signed at the lower right, Rossano.

F-

$$
\begin{gathered}
\text { Height, 1t inches; width, 81/2 inehes } \\
\text { Canvas on wood }
\end{gathered}
$$

Four trees growing in a group by themselves on the bank of a river.

Signed at the lower left, Rossano. 


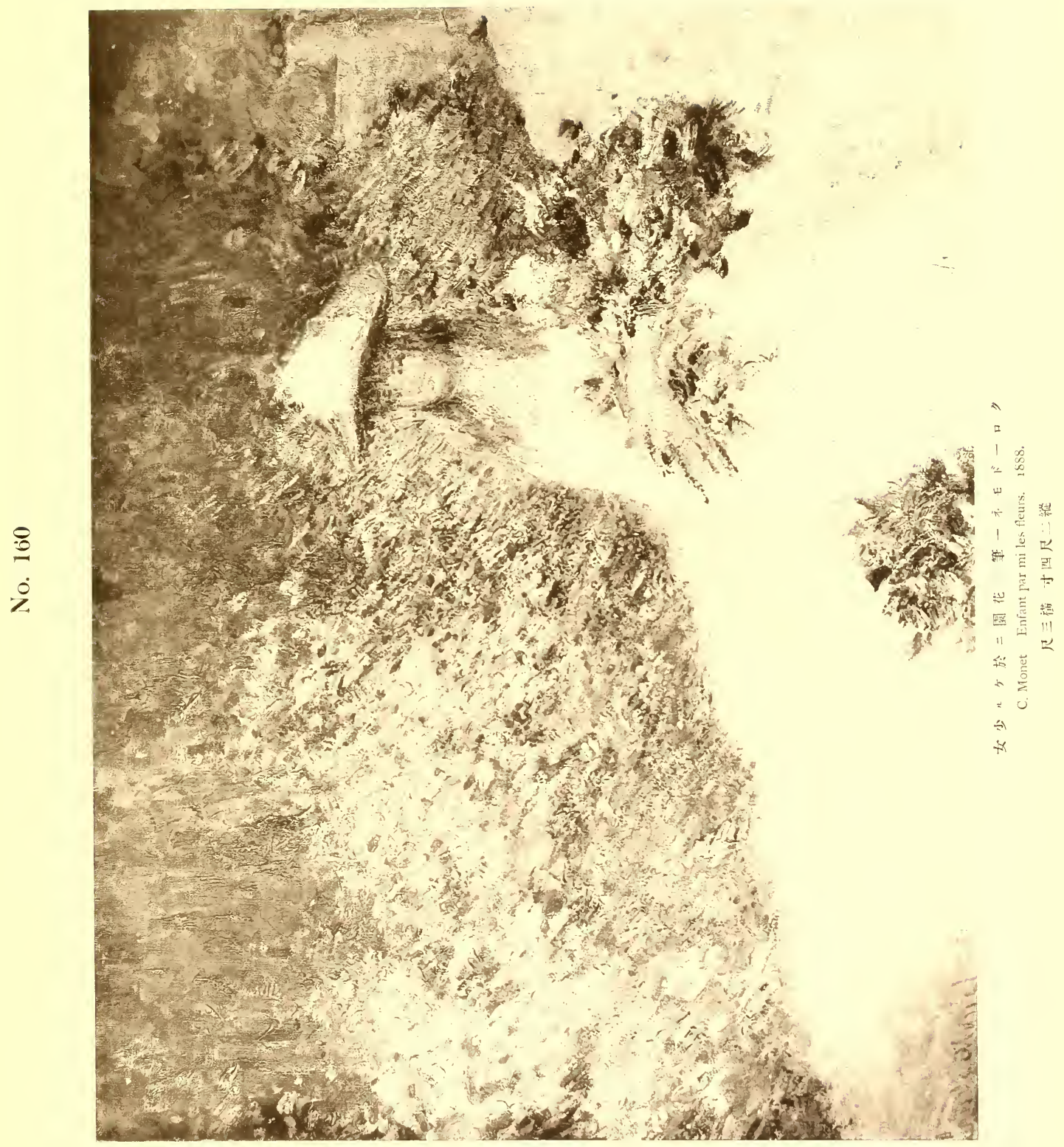


No. 160

\section{CLAUDE MONET}

FRENCH

1840-

\section{ENFANT PARMI LES FLEURS}

Height, 281/2 inches; length, 36 inches

A young girl in a light dress and summer hat-her thick brown hair in loose form straggling forward over either shoulder-who has been gathering flowers in a bountiful garden, comes forward, arm-laden, on one side, with longstemmed blossoms, and carrying in her other hand a basket quite as full of her prodigal pluckings. She walks in a broad garden path bordered by riotous blooms, which bank up against and before a green mass of trees and shrubs. The floral bank ceases in the distance and discloses a garden wall at the head of the path.

Signed at the lower left, (laude Monet, "88. 


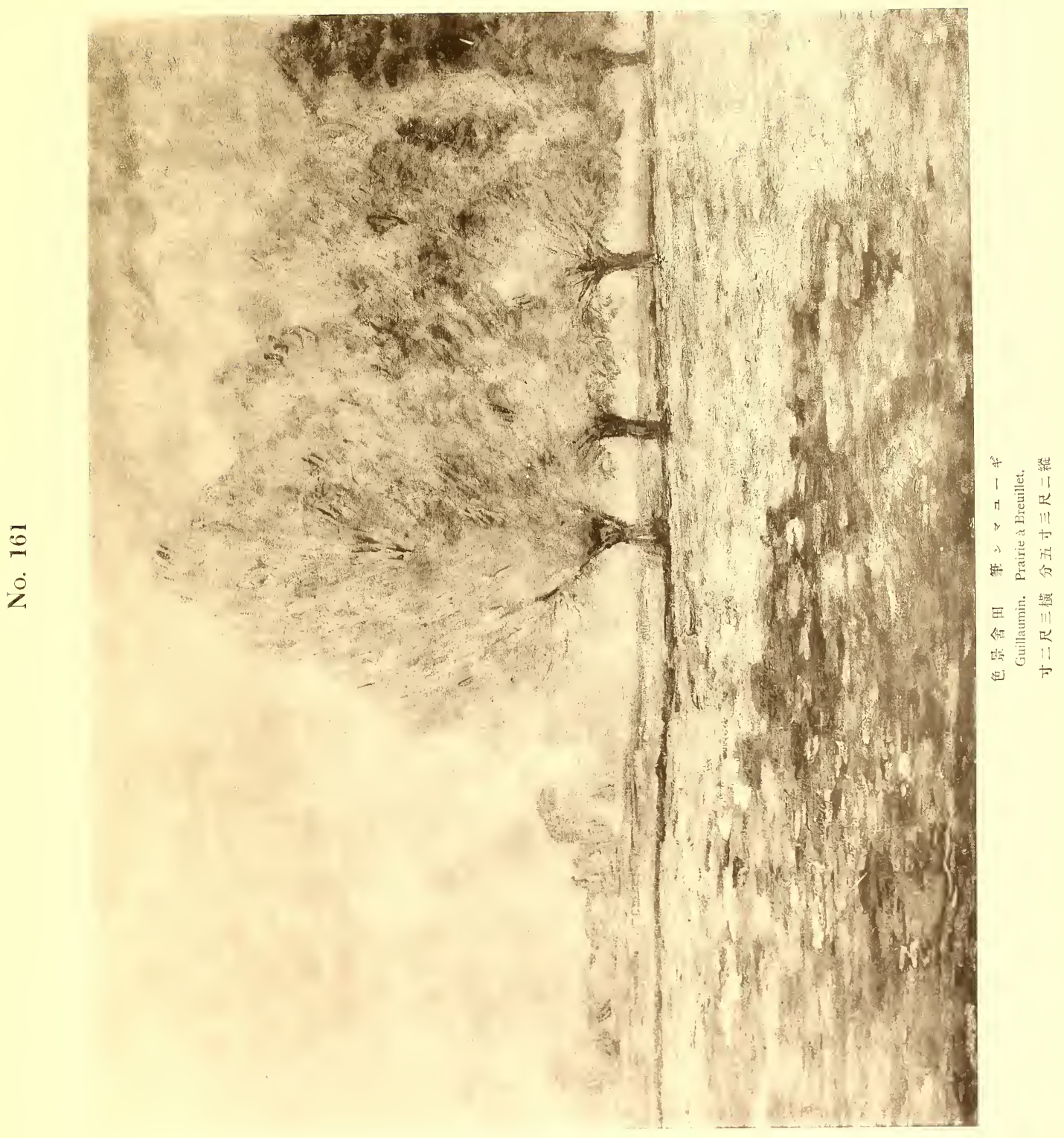


No. 161

ARMAND GUILLAUMIN

FRENCH

1841-

\section{PRAIRIE A BREUILLET}

Height, 281/2 inches; length, 36 inches

A frat field, freely painted in outdoor lights, where the middle distance is broken by a line of broadly conical trees traversing the canvas from center to the right. Beyond them at the left, across the meadow of the title, appear suggestions of a village. In the extreme distance is discernible one of those midsummer illusions of the superhorizon which may be a mountainous bank of clouds, their contour varied as the sunlight strikes them, or a cloudband overlying and partly obscuring veritable mountains.

Signed at the lower left, Guillaumin.

On the back is written: "Prairie à Breuillet, Juin, 1870." 


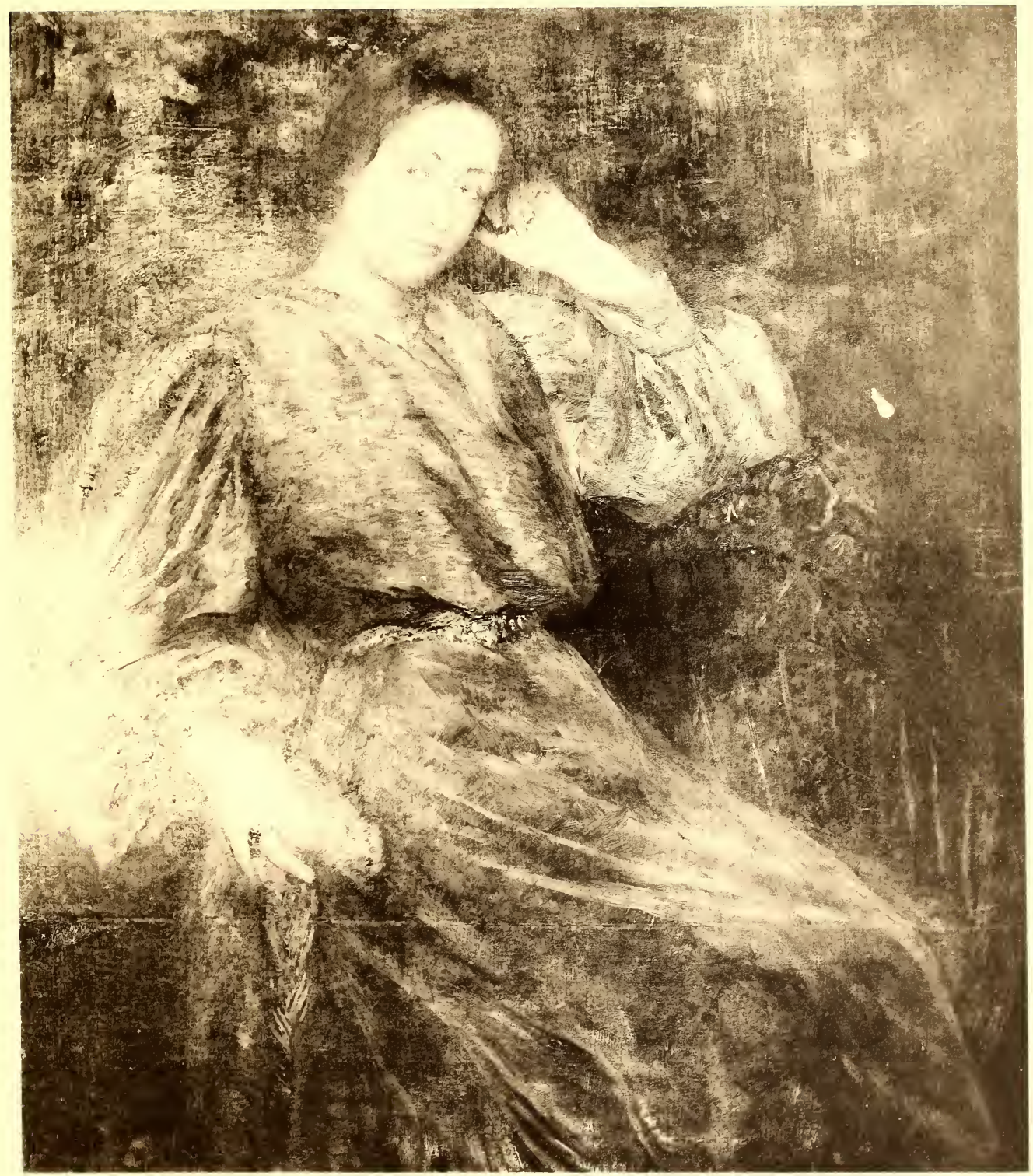

像少已自筆少

L. Bresau. Portrait de l'artiste,

寸一尺三棌分五寸六尺三維 
No. 162

\section{LOUISE BRESLAU}

GERMAN

1856-

\section{PORTRAIT DE L'ARTISTE}

Height, $4+$ inches; width, 38 inches

THE artist appears in a brown skirt, and a quiet-colored waist loose at the neck and with flowing sleeves, seated easily in a wicker chair. She is seen at three-quarter length, corner-wise of the chair, her left elbow resting on the chairback, the arm flexed to support her head. Her right hand rests on the chair arm and displays a single ring. The features are sensitive and refined, and the quiet, greenish-blue eyes look straight at the spectator. Neutral background.

Signed at the lower left, L. B. (in monogram), 1895. 
No. 163

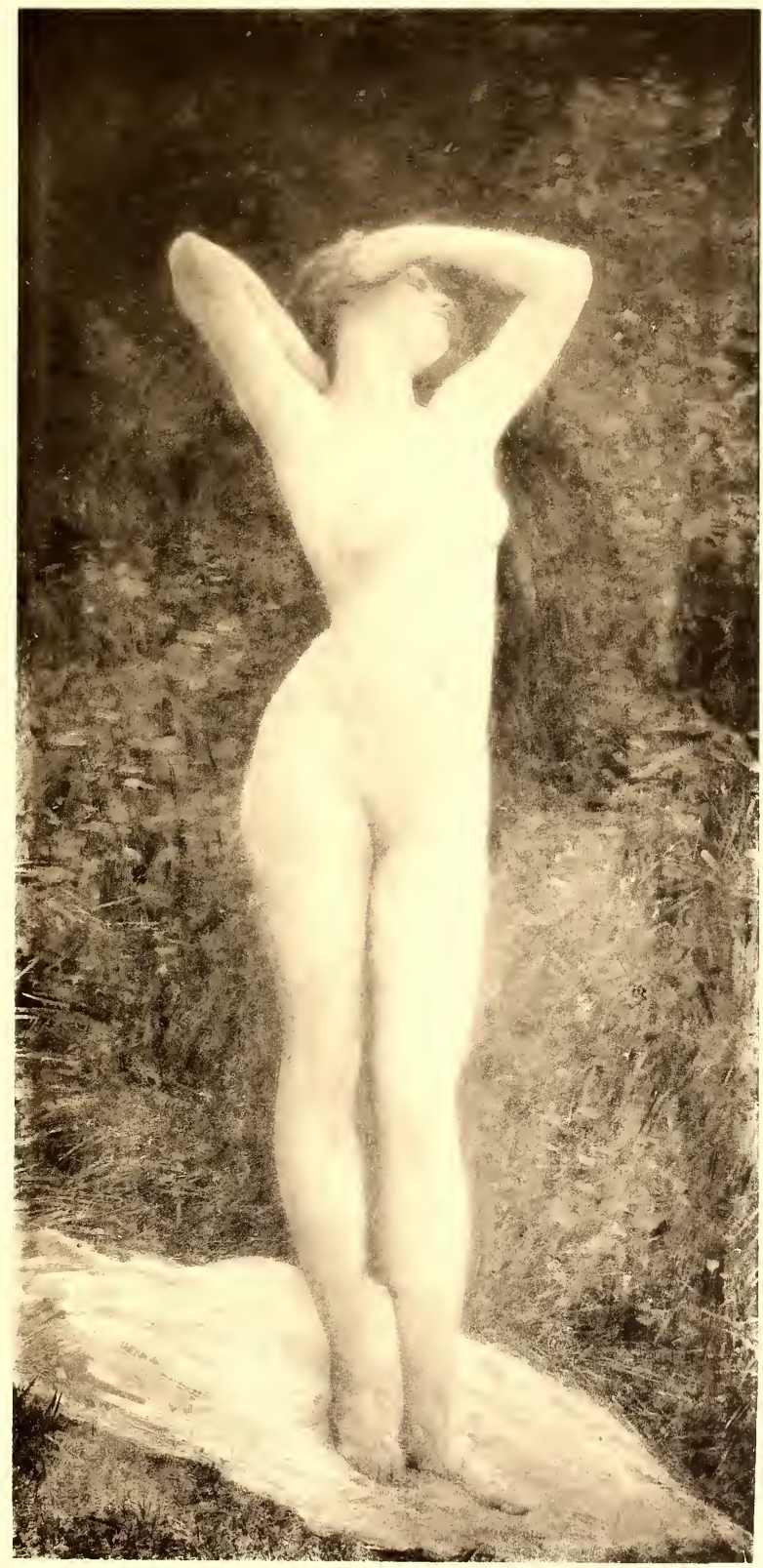
人美兴量
裸等 こ
分五打五尺三横
分五计一尺七緥 
No. 163

\section{LOUIS JOSEPH RAPHAEL COLLIN \\ FRENCH}

1850 -

\section{NUDE}

Height, 85 inches; aidth, 411 르 inches

A mamben of trim figure is posed, standing, on a bit of white drapery thrown over the grass of an open spot in the midst of what might be a thick green wood. She faces the right, three-quarters front, and leans her head back over her left shoulder, both hands raised and folded about her head-her eyes lightly closed. Her long red hair hangs down her back below her waist and is lightly blown out at one side, intervening between the flesh tones and the solid green background.

Signed at the lower left, R. Collin, 1893.

Exhibited at the International Exhibition at Copenhagen. 
No. 164

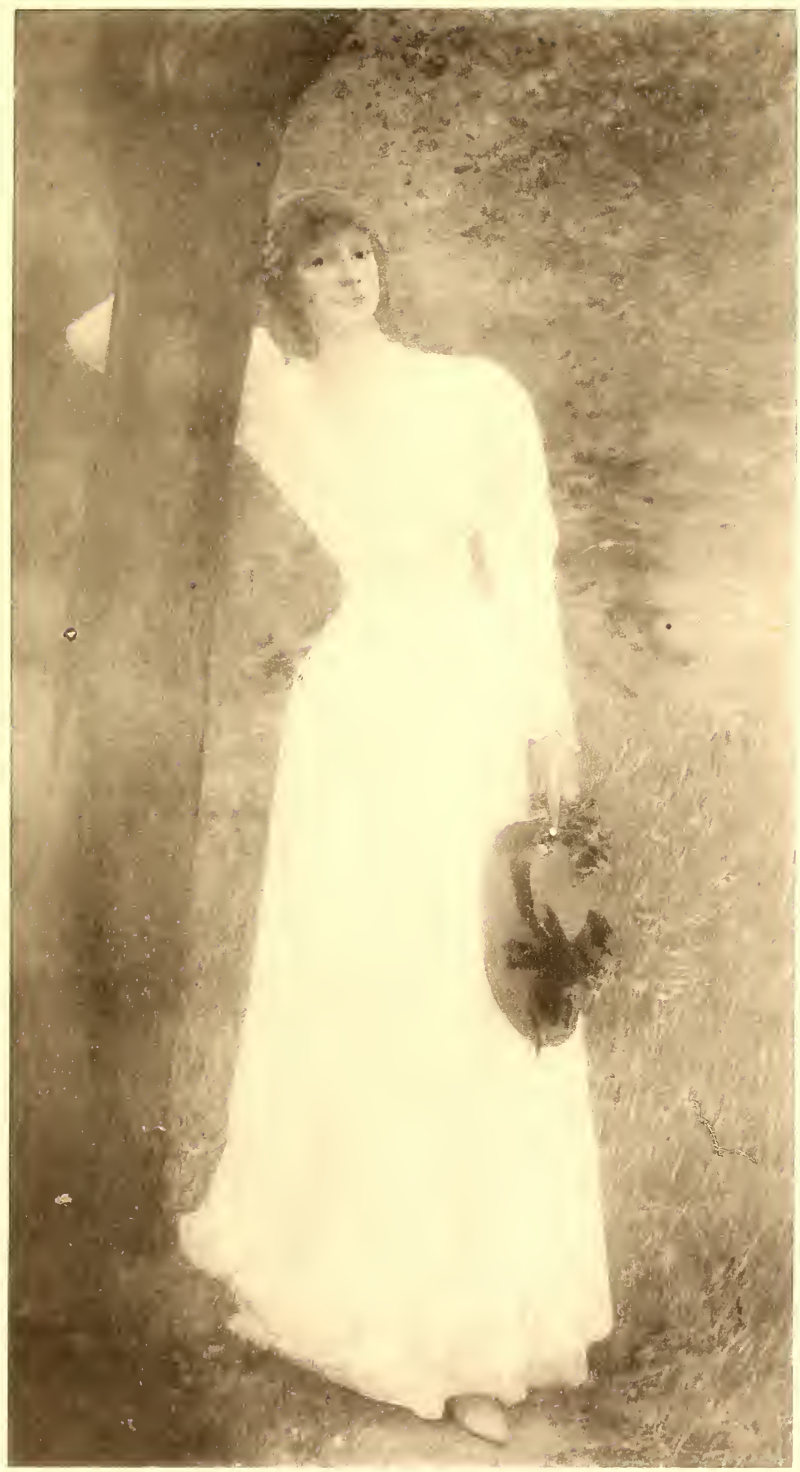

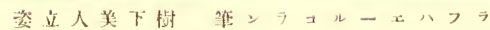

R. Collin. Dame sous l'arbre.

寸八尺三獚甫八尺六繦 
No. 164

\section{LOUIS JOSEPH RAPHAEL COLLIN}

FRENCH

1850-

\section{DAME SOUS L'ARBRE}

Height, 82 inches; width, 45 inches

A TALL young woman of resolute eyes, with light, reddishbrown hair, is seen at full length, standing, beneath a tree with a moss-grown trunk, against which she leans upon her upraised right arm in an easy attitude. She wears a pure white dress, slightly low at the neck and unadorned save by a white bow at the white belt. In her free hand she holds, hanging against her skirt, her flat leghorn hat trimmed with black and red. The background is the humid green of forest undergrowth.

Signed at the lower left, R. Collin, 1894.

Exhibited at the Exhibition of the Socićté des amis des arts, Bordeaux, 1902.

Exhibited at Helsingfors. 


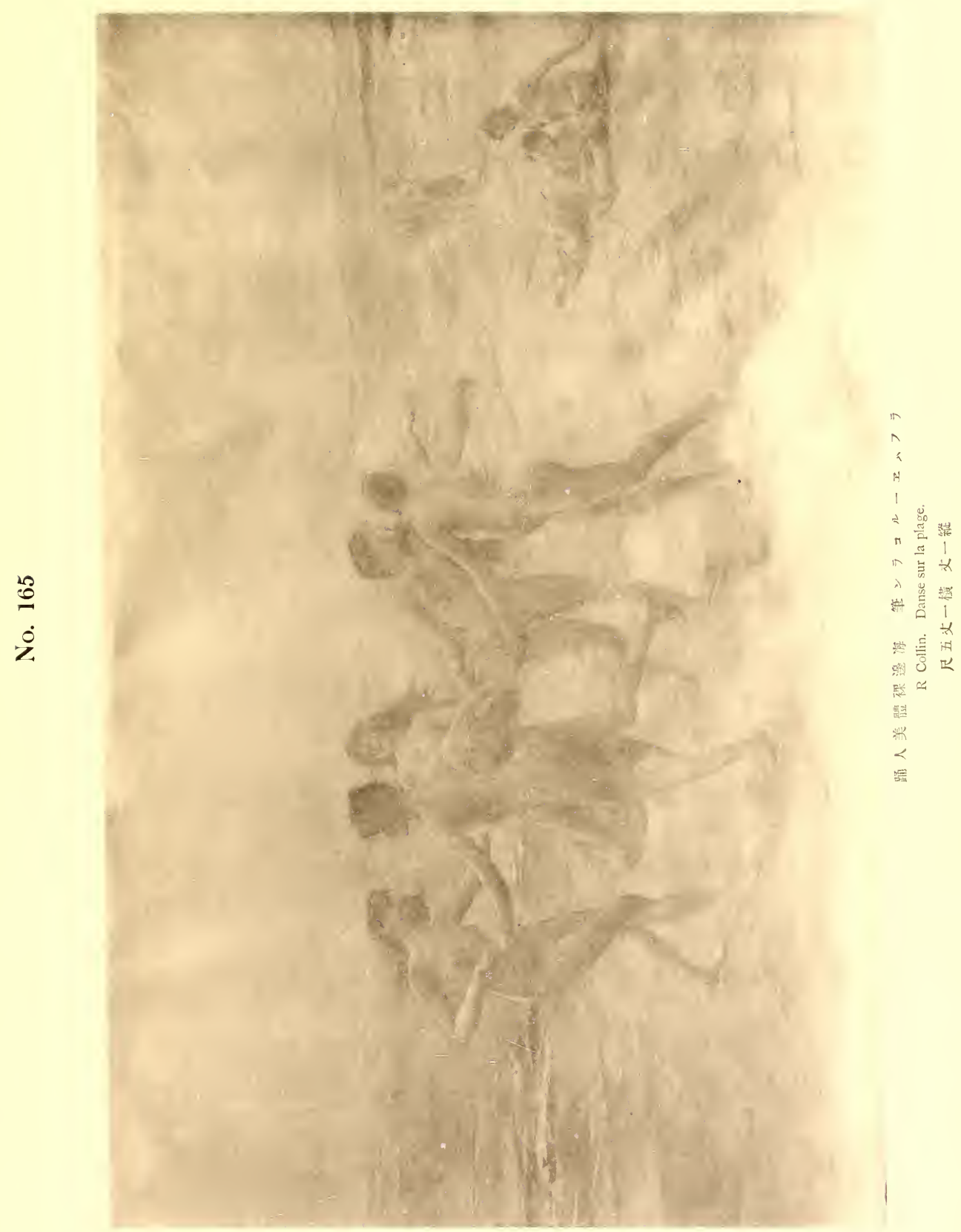


No. 165

LOUIS JOSEPH RAPHAEL COLLIN

FRENCH

18.50 -

\section{DANSE SUR LA PLAGE}

Height, $11 \%$ inches; length, 176 inches

ON the gray-brown sands of a broad beach a group of five maidens, all, save one, nude, are frolicking in a dance. Their hands are clasped, except that two of the dancers have opened their hands to make room for others of their companions, to whom they are beckoning, who are lying on the sands. At the feet of the dancing nymphs the green-blue sea comes in in gentle wavelets, breaking in low, white ripples at the left of the graceful, joyous figures. The single girl clad is in a filmy, purple drapery, which like the hair of some of the dancers that has been allowed to fall down their backs, sways with the light breeze and the motion of the sport. Further down the beach still other figures are perceived, and the blue hills of the distance fade into a horizon haze. This canvas was painted from the preliminary sketch that appears as No. 136 of this collection, which has been pretty faithfully followed, with slight changes in some of the poses and the omission of some details, while the figures and their expression are carried farther.

Signed at the lower right, R. Collin, 1892.

Anierican Art Association

'Thomas E. Kirby

Managers

Auctioneer 